\title{
CORREDORES ECOLÓGICOS NA RESERVA DA BIOSFERA DO CINTURÃO VERDE DE SÃO PAULO
}

- POSSIBILIDADES E CONFLITOS

\author{
Faculdade de Arquitetura e Urbanismo da Universidade de São Paulo \\ ÁREA DE CONCENTRAC̣ÃO: Paisagem e Ambiente
}

SÃO PAULO

2012 


\title{
JULIA RODRIGUES LEITE
}

\section{CORREDORES ECOLÓGICOS NA RESERVA DA BIOSFERA DO CINTURÃO VERDE DE SÃO PAULO \\ - POSSIBILIDADES E CONFLITOS}

Tese apresentada à Faculdade de Arquitetura e Urbanismo da Universidade de São Paulo para obtenção do título de Doutora em Arquitetura e Urbanismo.

ÁREA DE CONCENTRAÇÃO: Paisagem e Ambiente

ORIENTADOR: Prof. Dr. Paulo Renato Mesquita Pellegrino

EXEMPLAR REVISADO E ALTERADO EM RELAÇ̃̃O À VERSÃO ORIGINAL, SOB RESPONSABILIDADE DO AUTOR E ANUÊNCIA DO ORIENTADOR.

0 original se encontra disponível na sede do programa. São Paulo, 12 de Setembro de 2012.

\author{
SÃO PAULO \\ 2012
}


AUTORIZO A REPRODUÇÃO E DIVULGAÇÃO TOTAL OU PARCIAL DESTE TRABALHO, POR QUALQUER MEIO CONVENCIONAL OU ELETRÔNICO, PARA FINS DE ESTUDO E PESQUISA, DESDE QUE CITADA A FONTE.

Endereço eletrônico para contato:juliardl@gmail.com

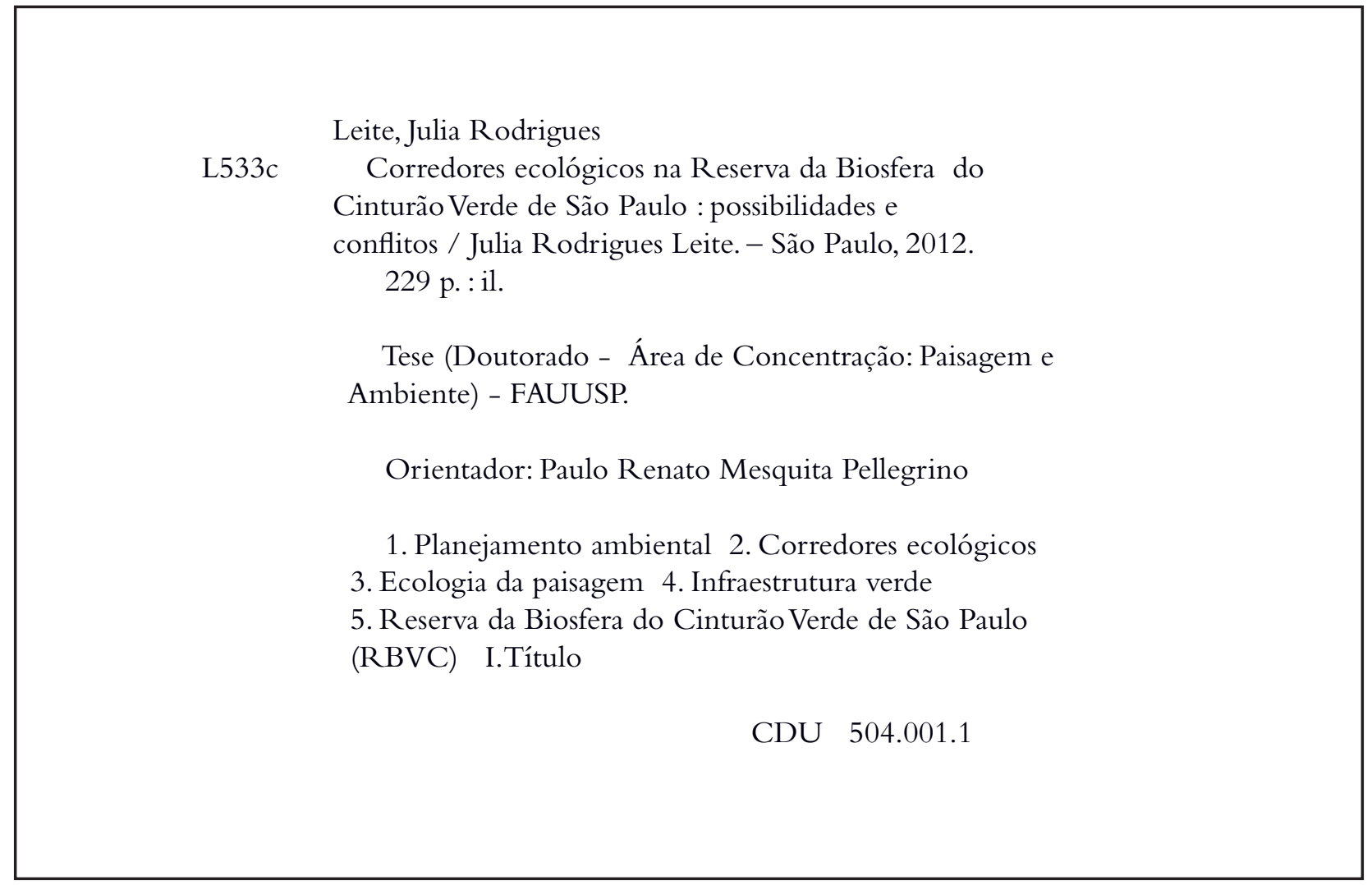




\section{NOME: LEITE, Julia Rodrigues}

Título: Corredores Ecológicos na Reserva da Biosfera do Cinturão Verde de São Paulo - Possibilidades e Conflitos

Tese apresentada à Faculdade de Arquitetura e Urbanismo da Universidade de São Paulo para obtenção do título de Doutora em Arquitetura e Urbanismo, Área de Concentração Paisagem e Ambiente.

Aprovado em:

Banca Examinadora

Prof. Dr. Instituição:

Julgamento: Assinatura:

Prof. Dr. Instituição:

Julgamento: Assinatura

Prof. Dr. Instituição:

Julgamento: Assinatura:

Prof. Dr. Instituição:

Julgamento: Assinatura:

Prof. Dr. Instituição:

Julgamento: Assinatura: 
À FAPESP - Fundação de Amparo à Pesquisa Científica do Estado de São Paulo pelo apoio financeiro e institucional (Processo no. 07/57736-8);

Ao banco Santander pela Bolsa "Mobilidade Internacional" para estágio acadêmico na Universidade Técnica de Lisboa;

Paulo Pellegrino por sua importante orientação e estímulo sem os quais não teria sido possível realizar este trabalho;

A Isa e toda equipe da Secretaria da Pós Graduação, Secretaria do Departamento de Projeto e Bibliotecas da FAUUSP;

Manuela Raposo Magalhães por sua supervisão no estágio acadêmico internacional no Centro de Estudos em Arquitetura Paisagista (CEAP) e auxílio na delimitação da Estrutura Ecológica da Paisagem. Também aos demais colegas do CEAP pela agradável convivência e trocas acadêmicas;

Eduardo Salinas, grande professor, por sua ajuda e ensinamentos com metodologias de ordenamento do território;

Katia Mazzei e Euler Sandeville pelas importantes observações durante o meu exame de qualificação;

Ao Comitê Gestor da Reserva da Biosfera do Cinturão Verde da Instituto Florestal, pelo apoio com dados e discussões sobre a Reserva e Planos Diretores Municipais;

Adão Modesto pela colaboração com a interpretação das imagens de satélite para avaliação temporal do crescimento urbano;

Claudia Perrota pela leitura e revisão do texto;

Pedro Ursini, por ter colaborado com a arte gráfica da Tese e dos mapas com tamanha paciência e ter iluminado a direção de arte e finalização do trabalho;

Aos meus amigos e família, meu pai Celso Luiz e mãe Edmara, por estarem sempre do meu lado a me apoiar;

Arthur por seu amor, compreensão e carinho que fazem a vida mais feliz. 


\section{LISTA DE MAPAS}

Mapa 01 - Área de Estudo Inserida no Limite Oeste da Reserva da Biosfera do Cinturao Verde................................................75

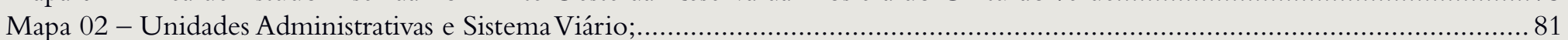

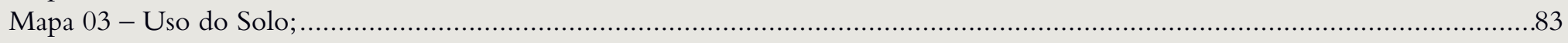

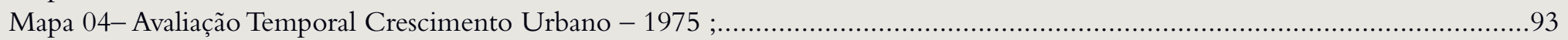

Mapa 05- Avaliação Temporal Crescimento Urbano - 1986; .....................................................................................94

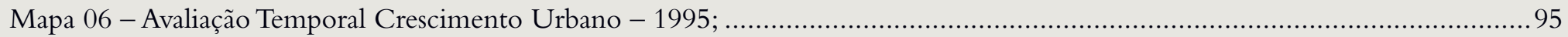

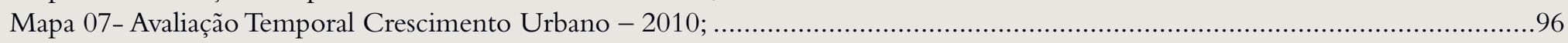

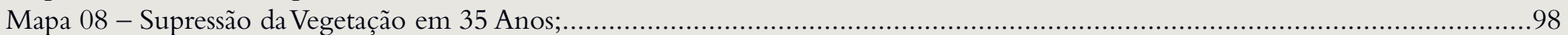

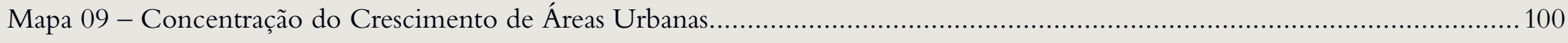

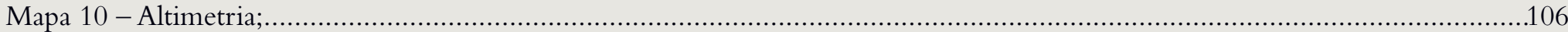

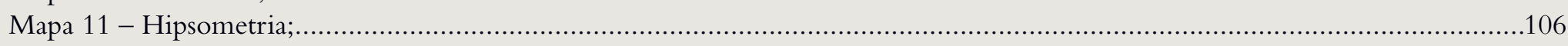

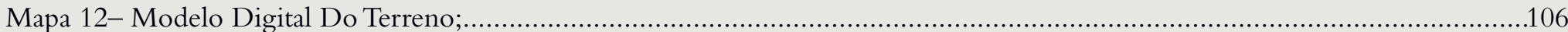

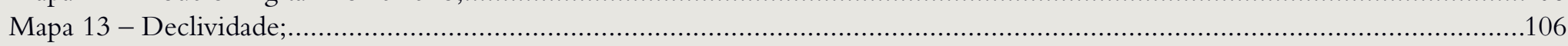

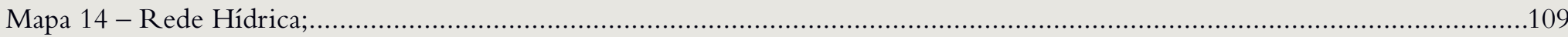

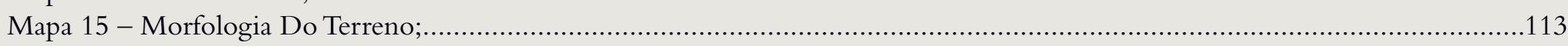

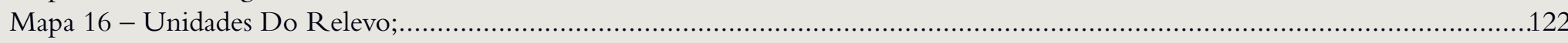

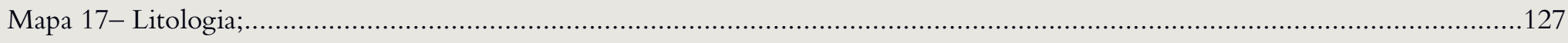

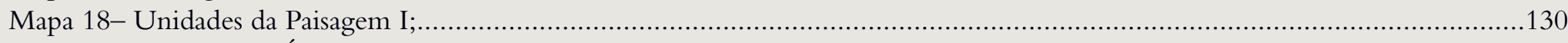

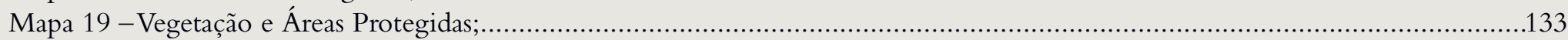

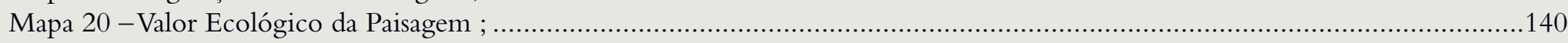

Mapa 21-Valores Ecológicos Baixo e Muito Baixo Vulneráveis a Deslizamentos e Inundações ..................................................141

Mapa 22- Desenho Macro do Sistema de Corredores Verdes....................................................................................142

Mapa 23 - Potencialidades de Fluxos na Paisagem Natural...................................................................147

Mapa 24 - Hierarquização das Áreas de Interesse no Eixo Principal...................................................................................155

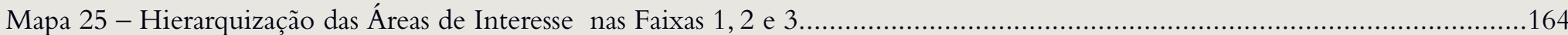

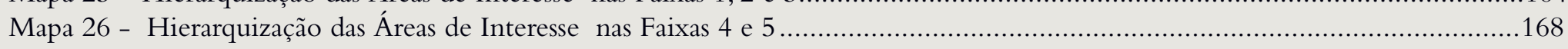

Mapa 27 - Possibilidades para Implementação dos Corredoes .Eixo Principal - Setor ……………......................................180

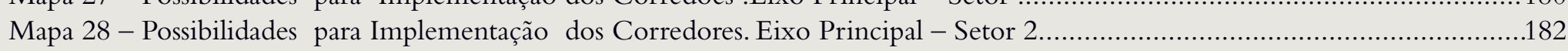

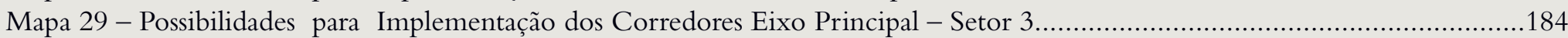

Mapa 30 - Possibilidades para Implementação dos Corredores Faixa Secundária 1 ......................................................................186

Mapa 31 - Possibilidades para Implementação dos Corredores Faixa Secundária 3 .............................................................188 


\section{LISTA FIGURAS}

FIGURA 1 - Maneiras de se estabelecer a conectividade. a) Manejo de um mosaico de habitats para facilitar o movimento. b) e c) Manutenção de habitats específicos que permitam o deslocamento em ambientes hostis, sendo que este padrão pode ter a forma de trampolins ecológicos com variados tamanhos e distâncias (b) ou ser um corredor de habitat que fornece uma conexão continua (c). (adaptado de BENNET, 2003)

FIGURA 2 - Corredor Mesoamericano. Disponível em )

http://www-radar.jpl.nasa.gov/centralamericamap/ca/index.htm. Acessado em 21/10/2011)

FIGURA 3 - Corredor de ligação da Estação Biológica La Selva (La Selva Biologica Station). Fonte http://life.ou.edu/pubs/ reserves/node14.html. Acessado em 25/10/2011.).

FIGURA 4 - Ponte para travessia de animais. Autor: Michael Van Valkenburgh \& Associates, New York, 2011. Disponivel em : http://www.nytimes.com/2011/01/24/science/earth/24overpass.html?_r=1. Acessado em 10/1//2011)

FIGURA 5 - De fundamental importância ao plano é o Continuum Naturale, um sistema contínuo (corredor) de elementos naturais que permitem o funcionamento e desenvolvimento dos ecossistemas e a permanência do potencial genético (biodiversidade)

FIGURA 6 É possível visualizar um exemplo de aplicação da estrutura ecológica, no caso, o estudo da Estrutura Ecológica Metropolitana de Lisboa, em que os sistemas da paisagem foram identificados e apresentados. (Fonte: Magalhães, 2007)......

FIGURA 7 - Imagem do Plano Mosaico Territorial Barcelona. Alternativa apresentada por Forman (2004), considerada, pelo autor, como a mais promissora, em termos de conservação de ecossistemas.

FIGURA 8 Situação dos rios e córregos na cidade de Zurique. Projeto Stream (City of Zurique, 2007)

FIGURA 9 - Áreas de Proteção: Parque Estadual da Serra da Cantareira, Reserva do Morro Grande, Parque Estadual Juqueri, APA Itupararanga, APA Cajamar e APA Sistema Cantareira, localizadas no trecho Oeste da RMSP.

FIGURA 10 - Avaliação temporal do crescimento urbano. Base: Satélite Landsat 5 nas datas: 27/05/1975; 19/06/1986; 28/06/1995; $04 / 05 / 201$

FIGURA 11 - Exemplo de um uso em Área Núcleo Proposta, uma área de recomposição de APP, lindeira a um rio, em que a preservação do ecossistema e os processos ecológicos da fauna podem ser combinados com outros usos, como pastoril, recreação e lazer (Fonte: BLACK; DUI e TOBAR, 1991: 86) 


\section{LISTA DE FIGURAS}

FIGURA 12 - Equipamentos e atividades educativas aproveitando trechos com valor ecológico, paisagístico e cultural. São usos que podem ser atribuídos às Áreas de Novas Possibilidades Estratégicas (Fonte: BLACK; DUI e TOBAR,1991: 56).

FIGURA 13 - Detalhe em corte longitudinal do parque Königsquelle em Bad Wildungen, Alemanha, em que equipamentos de lazer foram projetados em locais que não interferem na estrutura ecológica da paisagem, de maneira que a natureza foi preservada, serviços ecológicos importantes foram mantidos e criou-se um amplo espaço para recreação, educação e lazer. (Fonte: MERTENS, 2010:51).

FIGURA 14 - Detalhe do "Projeto para Espaços Abertos”, bairro Khalifa City em Abu Dhabi, Emirados Árabes - desenho do escritório Neumann Gusemburger, de uma calçada com abundante arborização e piso impermeável vegetado, que ilustra como a Área de Amortecimento pode ser tratada em uma estrada ou avenida, em trechos onde a urbanização é menos densa, de maneira a ser menos hostil à avifauna urbana e minimizar, por exemplo, o calor e a insolação locais (Fonte: MERTENS, 2010: 135)........

FIGURA 15 - Exemplo de Infraestrutura Verde para minimização de impactos para a fauna urbana e melhorias ambientais para a população. Tipologia de Rua Jardim. Fonte FUSP/FAUUSP, 2009. Coordenação Técnica da Autora.

FIGURA 16 - Exemplo de Infraestrutura Verde para minimização de impactos para a fauna urbana e melhorias ambientais para a população. Tipologia de Avenida. Fonte FUSP/FAUUSP, 2009. Coordenação Técnica da Autora...

FIGURA 17 - Exemplo de Infraestrutura Verde para minimização de impactos para a fauna urbana e melhorias ambientais para a população. Tipologia de Rua Parque. Fonte FUSP/FAUUSP, 2009. Coordenação Técnica da Autora...

FIGURA 18 - Exemplo de Infraestrutura Verde para minimização de impactos para a fauna urbana e melhorias ambientais para a população. Tipologia de Rua APA. Fonte FUSP/FAUUSP, 2009. Coordenação Técnica da Autora.

FIGURA 19 - Ilustração de ponte de travessia pra animais sobre rodovia. Informações obtidas em http://www.backpacker.com/ june_2008_phenomenon_wildlife_crossings/nature/12456.Acessado em 12/02/2012.....

FIGURA 20 - Ponte de travessia para animais, Bannf National Park, Alberta, Canadá. acessado em http://www.mountainnature.com/ articles/CrossingStructures.htm

FIGURA 21 - Ponte para Travessia de Animais 26 Motorway na Hardt Forest,Alemanha. Obtida em http://graemelaidlaw. wordpress.com/.Acessado em 05/03/2012.......

FIGURA 22 - Ponte para travessia de animais sobre a Rodovia 69, Ontario Canadá. Obtida em http://dcnonl.com/article/id43072. Acessado em 05/03/2012. 
Tabela 1- Municípios incluídos na área de abrangência do estudo (EMPLASA, 2006)......

Tabela 2 - Informações sobre as rodovias estaduais e federais que atravessam a área de estudo (EMPLASA, 2006)..............................................79

Tabela 3: Classes de uso do solo encontradas na área de abrangência de estudo, suas áreas e percentuais da área total......................................... 84

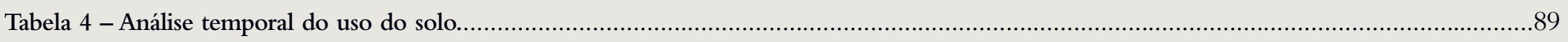

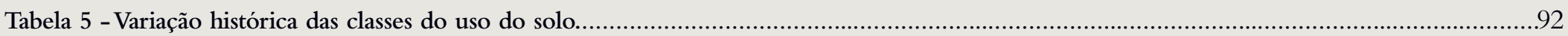

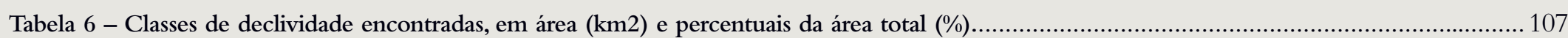

Tabela 7 - Classes Altimetricas identificadas na área de abrangência de estudo, com as cotas que as representam e suas característica.......................117

Tabela 8 - Valores das inclinações do terreno que correspondem a cada Classe de Declividade..................................................................118

Tabela 9 - Matriz de cruzamento de informações e interpretação das Unidades de Relevo da Paisagem ........................................................120

Tabela 10 - Unidades de Relevo, suas características e observações.......................................................................................................121

Tabela 11 - Interpretação do Mapa Geomorfológico do Estado de São Paulo (CPRM- SGB,2010) para a determinação

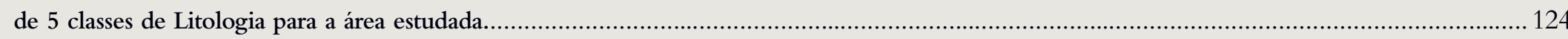

Tabela 12- Classes de Litologia identificadas na área de estudo (CPRM- SGB, 2010)...............................................................................125

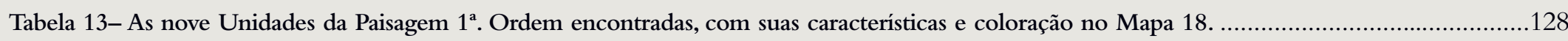

Tabela 14- Tipologias de de área não urbanizadas encontradas na Área de Estudo - RMSP........................................................................132

Tabela 15 - As 55 Unidades da Paisagem encontradas na área estudada e agrupadas por seu valor ecológico:Verde -Muito Alto (5) ;Verde Claro Alto

(4) ; Amarelo -Médio (3); Azul Claro -Fraco (2); Azul Escuro -Muito Fraco (1).................................................................................134

Tabela 16 - Municípios encontrados no eixo principal do Sistema de Corredores, as áreas que ocupam e seus respectivos percentuais..................151

Tabela 17 - Municípios encontrados na Faixa Indicativa 1 do Sistema de Corredores, as áreas que ocupam e seus respectivos percentuais(\%).........156

Tabela 18 - Municípios encontrados na Faixa Indicativa 2 do Sistema de Corredores, as áreas que ocupam e seus respectivos percentuais(\%).........159

Tabela 19 - Municípios encontrados na Faixa Indicativa 3do Sistema de Corredores, as áreas que ocupam e seus respectivos percentuais(\%)..........161

Tabela 20 - Municípios encontrados na Faixa Indicativa 4 do Sistema de Corredores, as áreas que ocupam e seus respectivos percentuais(\%).........165

Tabela 21 - Municípios encontrados na Faixa Indicativa 5 do Sistema de Corredores, as áreas que ocupam e seus respectivos percentuais(\%) ........167 


\section{LISTA DE QUADROS}

QUADRO 1 - Síntese dos procedimentos utilizados para a determinação e desenho da Morfologia Natural da Paisagem, parte da Estrutura Ecológica Fundamental.

QUADRO 2: Síntese do potencial de eficiência/efetividade de diferentes tipos de ligações entre paisagens que apresentam diferentes níveis de alterações (distúrbios) ambientais (adaptado de Bennet, 2003).

QUADRO 3 - Áreas de conservação e preservação municipais identificadas nos municípios, dentro da área de abrangência do estudo........87

QUADRO 4 - Síntese dos elementos componentes da Estrutura Ecológica Fundamental.

\section{LISTA DE GRAFICOS E DIAGRAMAS}

GRÁFICO 1 - Análise temporal das classes de uso do solo.

GRÁFICO 2 - Histograma da análise temporal das classes de uso do solo......

GRÁFICO 3 - Crescimento relativo em percentuais (\%) de cada classe de uso do solo.

DIAGRAMA 1- Elementos principais da relação SIG-Base de Dados dos Elementos da Paisagem 115

DIAGRAMA 2 - Esquema Geral da elaboração de Unidades da Paisagem 116 
FOTO 10 - Alagado em Griespark (Foto: Julia R. Leite, Junho/2011)

FOTO 2 - Imagem da parte central da cidade de Lisboa. É possível visualizar alguns elementos da estrutura ecológica: ao fundo, a colina com o Parque Monsanto, ao meio, um continuum naturale que se inicia na Avenida da Liberdade, passa pelo Parque Urbano Eduardo VII e pelo CorredorVerde da Monsanto, que, ao seu término faz a ligação com o Parque Monsanto para ciclistas e pedestres (Foto : Julia R. Leite, 05/2010) ..42

FOTO 3 - Parque linear com ciclovia e passeio e pedestre que constitui um corredor de ligação entre o parque Eduardo VII e o Parque Monsanto. Trecho arborizado do corredor verde; no fundo, é possível observar o Parque Monsanto. (Foto: Julia R. Leite, maio/ 2010) . .44

FOTO 4 - Estátua do Marquês de Pombal e a proximidade do parque com a arborização frondosa da Avenida da Liberdade, que configura um continuum naturale, proposto pelo Plano Verde. (Foto: Julia R. Leite, Maio/2010). .44

FOTO 5 - Parque urbano Zürichhorn, em Zurique, Suiça. Beira lago, de multiplos usos: lazer, recreação e cultura. (Foto: Julia R. Leite, Junho/2011) . .46

FOTO 6 - Parque urbano Zürichhorn, em Zurique, Suiça. Beira lago, de multiplos usos: lazer, recreação e cultura. (Foto: Julia R. Leite, Junho/2011). (Foto: Julia R. Leite, Junho/2011) .47

FOTO 7-Passarela sobre lagoa de tratamento de água no FirmenPark FOTO 8 - Parque de vizinhança, Wahlenpark (Foto: Julia R. Leite, Junho/2011). .47

FOTO 9 - Campo de trigo no Griespark, (Foto: Julia R. Leite, Junho/2011) .47

FOTO 11 - Vegetação suspensa na MFO Park 1 (Foto: Julia R. Leite, Junho/2011). 47

FOTO 12 - Árvores em série no Oerlikerpark(Foto: Julia R. Leite, Junho/2011). Fotos dos Parques ......................................... 154

FOTO13/14 Córregos renaturalizados, Zurique. . .48

FOTO 15- Fragmento de capoeira localizado no eixo principal proximo a Aldeia da Serra, Barueri. Foto:Julia R. Leite (2011) .154

FOTO 16 - Lago junto a fragmento de capoeira no condominio Residencial Aldeia da Serra localizado no eixo principal, Barueri. Foto: Julia R. Leite (2011) .154

FOTO 17 - Centro Comercial de Aldeia da Serra. Barueri-SP. Julia R. Leite (2011)...... .158

FOTO 18 - Fragmento de Mata em Área Homogênea deProteção Ambiental. Taboão da Serra-SP. Foto: Julia R.

Leite (2008)

FOTO 19 - Fragmento de Mata em Área Homogênea de Proteção Ambiental. Taboão da Serra-SP. Foto: Julia R. Leite (Julho/2008). ...158

FOTO 20 - Fragmento de Mata em Área Homogênea de Proteção Ambiental. Taboão da Serra-SP. Foto: Google Earth, (2008)

FOTO 21 - Fragmento de Mata em Área proposta para ser uma APA Municipal. Taboão da Serra-SP. Foto: Julia R. Leite Julho /2008). .159

FOTO 22 - Estrada de São Fernando seccionando duas manchas de vegetação. Observa-se grande condomínio de alto padrão 


\section{LISTA DE FOTOGRAFIAS}

em construção na área. Carapicuíba -SP. Foto: Julia R. Leite (Dezembro/2011)

FOTO 23 - Vegetação de mata e capoeira na margem do Rio Cotia, na Estrada São Fernando, também utilizada para agricultura familiar. Carapicuíba -SP. Foto: Julia R. Leite (Dezembro/2011)

FOTO 24 - Rio Cotia com suas margens naturalizadas próximo a área urbana . Barueri -SP. Foto: Julia R. Leite (Dezembro/2011) 160

FOTO 25 - Rio Cotia com suas margens naturalizadas, já mais deteriorado e poluído, em área urbana, próximo a sua foz. Baruer -SP. Foto: Julia R. Leite (Dezembro/2011) 160

FOTO 26- Fazenda Militar - Área verde extensa em Barueri. Foto: Julia R. Leite (2011) 162

FOTO 27- Fazenda Militar - Área verde extensa em Barueri. Foto: Julia R. Leite (Dezembro/2011) 162

FOTO 28 - Rio Tietê e a Foz do Rio Cotia. Construção de ponte até os condomínios Alphaville. Barueri-SP. Foto: Julia R. Leite (Dezembro/2011)

FOTO 29- Rio Barueri Mirim tamponado, próximo a sua foz, no Rio Tietê. A área do antigo rio foi transformada em um grande estacionamento. Barueri-SP. Foto: Julia R. Leite (Dezembro/2011) .163

FOTO 30 - Foz do Rio Cotia no RioTietê.Barueri-SP.Foto:Julia R. Leite (Dezembro/2011)

FOTO 31 - Área tamponad do rio Barueri Mirim sobre a qual foram criados jardins públicos ornamentais de escasso valor ecológico e de uso obsoleto da população. Barueri-SP. Foto: Julia R. Leite (Dezembro/2011)
FOTO 32 - Parque Ecológico Tietê-Núcleo Tamboré. Barueri-SP. Foto: Julia R. Leite (Setembro/2011). 166

FOTO 33 - Estrada de acesso ao Parque Ecológico Tietê-Núcleo Tamboré. Barueri-SP. Foto: Julia R. Leite (Setembro/2011). 166

FOTO 34 - Parque Ecológico Tietê-Núcleo Tamboré. Detalhe da margem do Rio - Barueri-SP. Foto:Julia R. Leite (2011)............166

FOTO 35 - Capivara junto a margem do Rio. Barueri. Foto: Julia R. Leite (Setembro/2011) 166

FOTO 36 - Conflito 8 - Condomínio em Aldeia da Serra exemplo de um centro urbano de baixa densidade, em lotes de tamanho médio, pela grande quantidade de condomínios da região, configuram-se como uma descontinuidade no sistema dos corredores ( Google Earth, 2012). 171

FOTO 37 - Conflito 10, bairro popular de Itapevi, baixa densidade de ocupaçao, não planejada e deficiente de infraestrutura urbana Nota-se a presença de terrenos vazio, mesmo que não seja este o destino destas áreas, ainda tornam o bairro mais permeavel e com vegetaçao que o tornam mais capaz de abrigar e conduzir deslocamentos especialmente da avifauna (Google Earth, 2012 ) .

FOTO 38 - Detalhe dos Conflito 11 e 13 , onde o centro deVargem Grande Paulista avança no sentido da borda do eixo principal e a Rodovia Raposo Tavares que secciona a área (Google Earth, 2012 ) ..

FOTO 39- Exemplo de situação que pode ser promovidas nas Áreas Núcleo Propostas, a presença dos fragmentos de vegetaçãojunto com atividades de agricultura familiar. Estrada de São de São Fernando. Cotia - SP ( Foto : Julia Leite, (Dezembro/2011).... .174 
ANAMMA: Associação Nacional de Órgãos Municipais de Meio Ambiente Secretaria da Casa

ANT: Área Natural Tombada

APAs: Áreas de Proteção Ambiental

APPS: Áreas de Preservação Permanente?

APRM: Áreas de Proteção e Recuperação dos Mananciais

CBH-AT: Comitê da Bacia Hidrográfica do Alto Tietê

CETESB: Companhia de Tecnologia de Saneamento Ambiental

CI: Conservação Internacional

CONDEPHAAT: Conselho de Defesa do Patrimônio Histórico,

Arqueológico, Artístico e Turístico

CONSEMA: Conselho Estadual do Meio Ambiente

CPRM: Companhia de Pesquisas e Recursos Minerais, do Ministé-

rio de Minas e Energia

CRIA: Centro de Referência e Informação Ambiental

EMPLASA: Empresa Metropolitana de Planejamento do Estado de São Paulo

FAESP: Federação de Agricultura do Estado de São Paulo

FAPESP: Fundação de Amparo à Pesquisa do Estado de São Paulo

FIESP: Federação das Indústrias do Estado de São Paulo

IFSP: Instituto Florestal de São Paulo

MAB: Man and Biosphere

MDT: Modelo Digital do Terreno

ONG: Organização não governamental
PDPAs: Planos de Desenvolvimento e Proteção Ambiental PEC: Parque Estadual da Cantareira

PJ-MAIS: Jovem - Meio Ambiente e Integração Social

RBCV: Reserva da Biosfera do Cinturão Verde de São Paulo

RBs: Reservas da Biosfera

RBUs: Reservas da Biosfera Urbanas

RFMG: Reserva Florestal do Morro Grande

RMSP: Região Metropolitana de São Paulo

RPPNs: Reservas Particulares de Proteção Natura

SABESP: Companhia de Saneamento Básico do Estado de São Paulo

SGB: Serviço Geológico do Brasil

SIG: Sistema de Informações Geográficas

SIGRH: Sistema Integrado de Gerenciamento de Recursos Hídricos

SMA:Secretaria Estadual de Meio Ambiente

SNUC : Sistema Nacional de Unidades de Conservação

TIN: Triangulate Irregular Network

UCA: Unidade de Conservação Ambiental

UNESCO: Organização das Nações Unidas para a Educação, a

Ciência e a Cultura

UNESP: Universidade Estadual Paulista

Unicamp : Universidade Estadual de Campinas

UNIFESP: Universidade Federal Paulista

USP: Universidade de São Paulo 


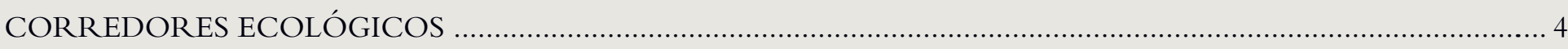

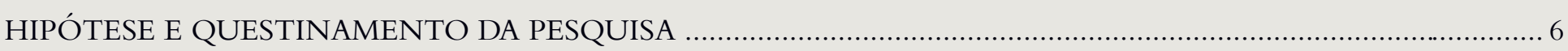

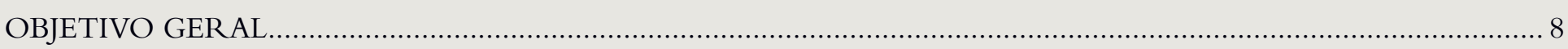

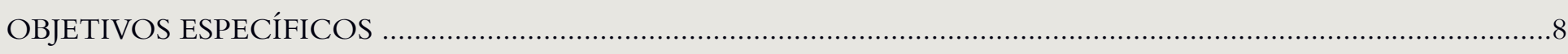

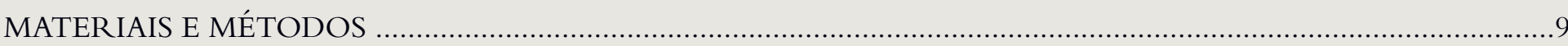

CAPÍTULO 1

BASES CONCEITUAIS PARA A CONFORMAÇÃO DE UM SISTEMA DE CORREDORESVERDEs........................23

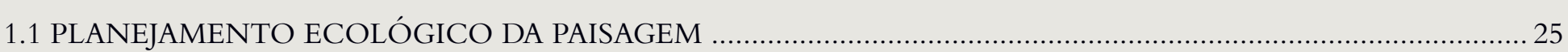

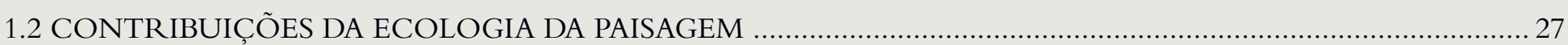

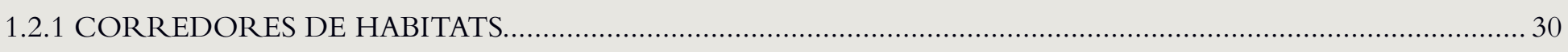

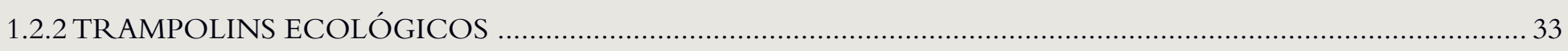

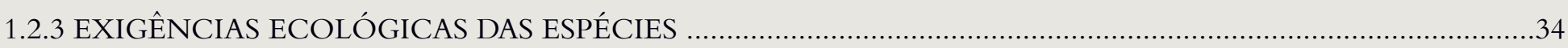

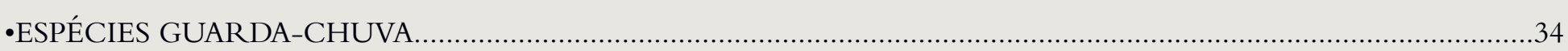

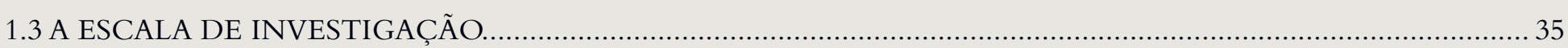

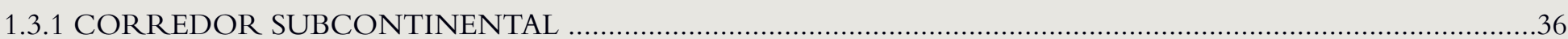

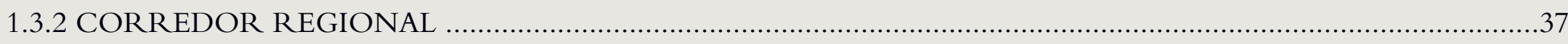

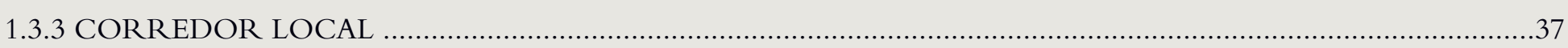

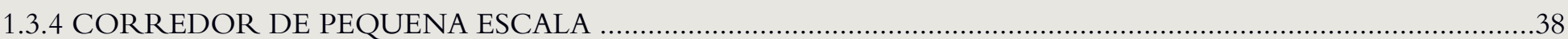

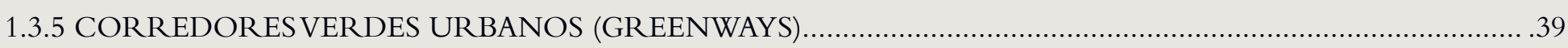

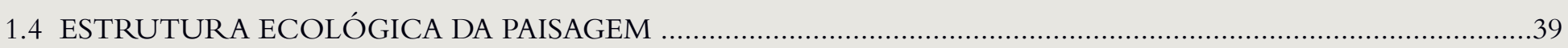

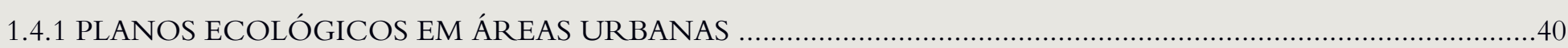

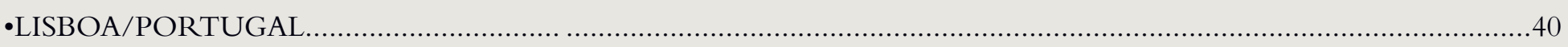

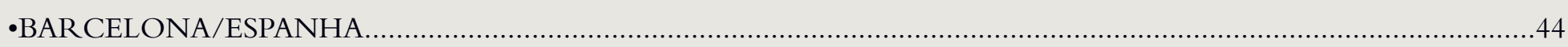

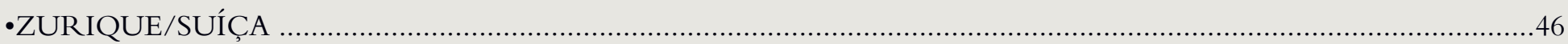

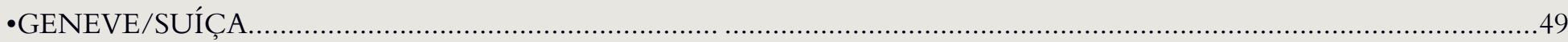




\section{CAPÍTULO 2}

ABORDAGEM REGIONAL E ÁREA DE ABRANGÊNCIA DO ESTUDO.

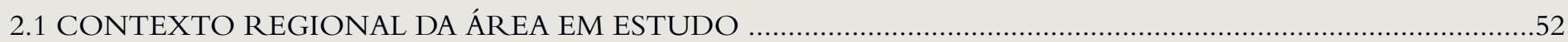

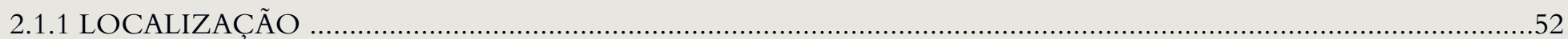

2.1.2 RESERVA DA BIOSFERA DO CINTURÃOVERDE DE SÃO PAULO (RBCV) ...................................................54

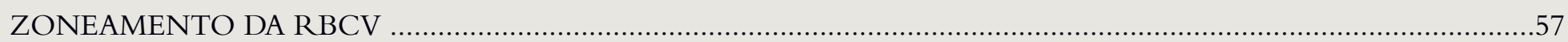

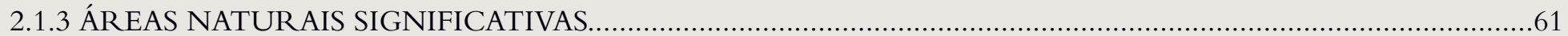

2.1.4 AVIFAUNA E MASTOFAUNA NO SETRO OESTE DA RBCV...........................................................................61

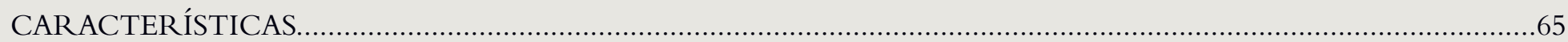

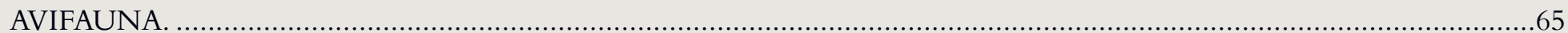

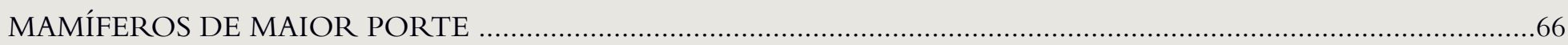

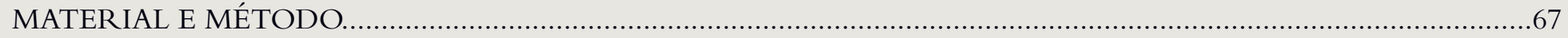

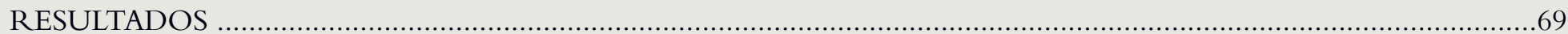

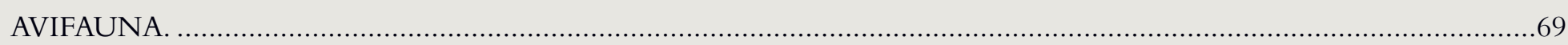

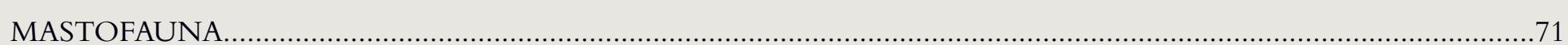

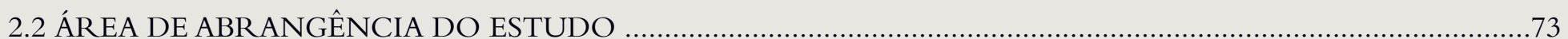

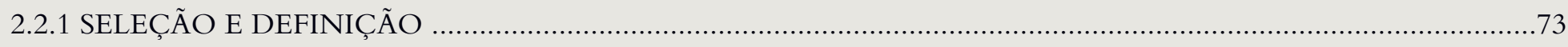

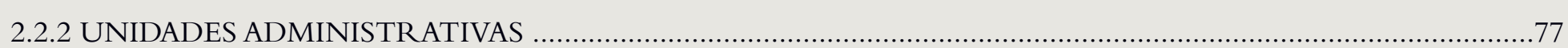

2.2.3 USO DO SOLO ….......................82

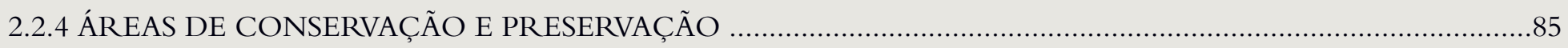

2.2.5 AVALIAÇÃO TEMPORAL DO CRESCIMENTO DA MANCHA URBANA...........................................................8 


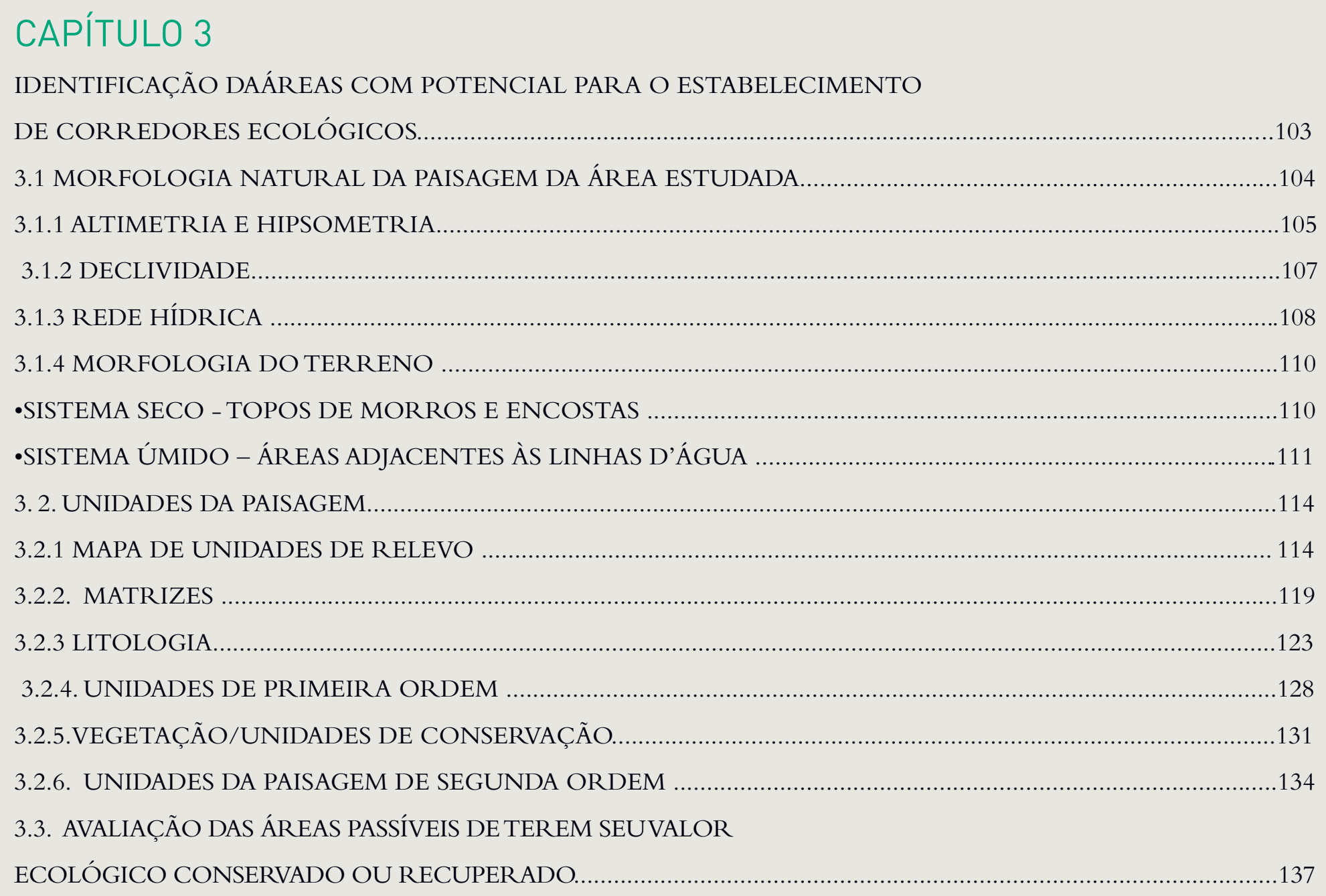




\section{CAPITULO 4}

DELINEAMENTO DAS FAIXAS DE ESTUDO PARA A VERIFICAÇÃO

DA IMPLEMENTAÇÃO DO SISTEMA DE CORREDORES ECOLÓGICOS....................................................... 145

4.1 TRAÇADO DAS FAIXAS DE CORREDORES ECOLOGICOS.......................................................................... 145

4.1.1 CLASSES DE GRAUS DE IMPORTANCIA PARA A CONDUÇÃO DE FLUXOS ECOLOGICOS.......................148

4.2 EIXO DO CORREDOR PRINCIPAL E SEUS EIXOS SECUNDÁRIOS.........................................................149

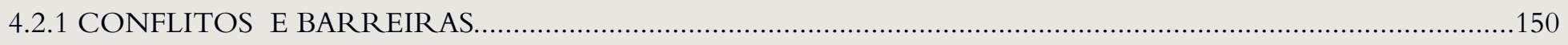

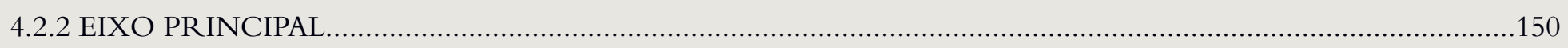

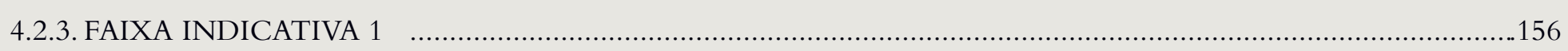

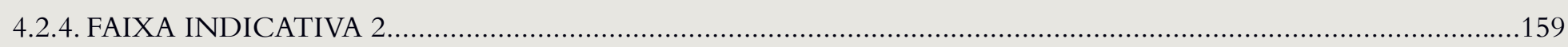

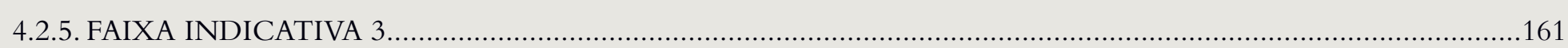

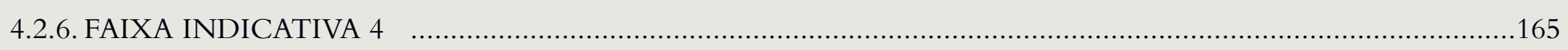

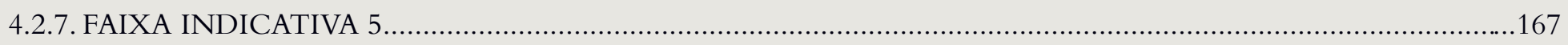

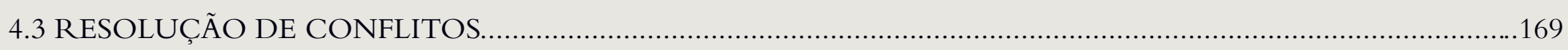

4.3.1. CONFLITOS CAUSADOS POR NÚCLEOS URBANOS...............................................................................170

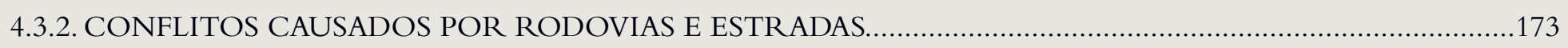

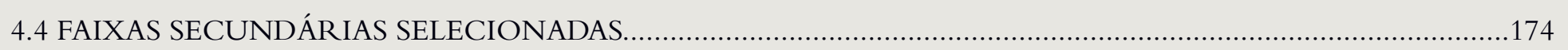

4.4.1. POSSIBILIDADES DE IMPLEMENTAÇÃO DO SISTEMA DE CORREDORES.............................................174

4.4.2. INFRAESTRUTURA VERDE NAS ÁREAS DE CONFLITO E ÁREAS DE TRANSIÇÃO................................190

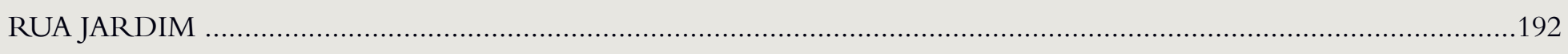

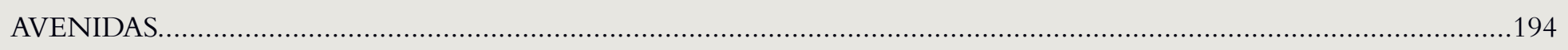

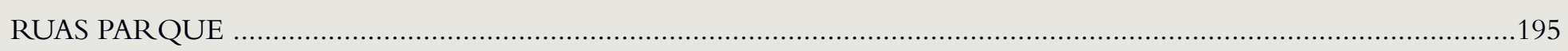

RUAS ÁREA DE PRESERVAÇÃO AMBIENTAL - APA ........................................................................................... 196

4.4.3. MEDIDAS MITIGADORAS SOBRE OS MPACTOS DE RODOVIAS PARA A FAUNA.....................................197

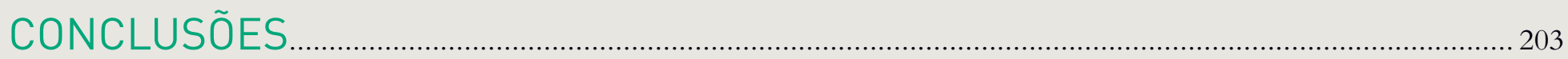

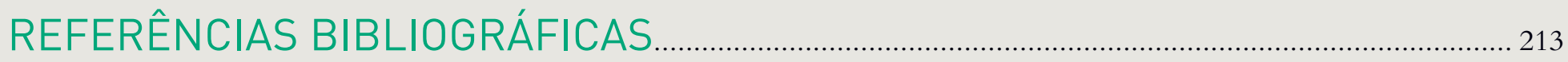




\section{RESUMO}

Esta tese propõe o desenvolvimento de um sistema de corredores ecológicos para o setor Oeste da Reserva da Biosfera do Cinturão Verde (RBVC), área que foi delimitada seguindo a metodologia e os objetivos do Programa Homem e Biosfera, da UNESCO. A área estudada localiza-se na Região Metropolitana de São Paulo e possui diversos instrumentos legais, bem como algumas unidades de conservação que são de extrema importância para a manutenção dos serviços ambientais e ecológicos na região. Além disso, no entremeio dessa área, considerada como Zona Núcleo pela RBCV, existem fragmentos de vegetação típica de Mata Atlântica em diversos estágios sucessionais, sujeitos a maior fragmentação e perda de habitat, os quais ainda hoje possuem potencial para condução de fluxos ecológicos, tanto para biodiversidade como de recursos hídricos, todos fundamentais à preservação da vida silvestre. O objetivo do trabalho foi então apresentar e discutir os conflitos, as barreiras e oportunidades, avaliados por uma abordagem fundamentada em princípios de ecologia da paisagem e planejamento ecológico, de modo a manter e aumentar os fluxos ecológicos no setor estudado pelas indicações de soluções que possam minimizar os conflitos mais desafiadores. $\mathrm{O}$ desenho do sistema de corredores foi fundamentado em avaliações da paisagem natural, feitas por meio de matrizes e diversos mapas temáticos, que indicaram áreas com alta relevância para processos ecológicos e conectividade. A cada escala de avaliação do processo de planejamento, o desenho foi sendo aprimorado. Partiu-se de uma escala regional, até a definição do traçado do eixo principal e de cinco faixas indicativas secundárias que compõem o sistema estudado. Como resultado, foi obtido o traçado do sistema macro de corredores, estabelecendo-se áreas com maior potencial para a condução dos fluxos ecológicos e a definição dos principais conflitos e barreiras para o deslocamento de animais. Por fim, para o eixo principal e suas faixas indicativas secundárias, foi feita uma proposta de implementação dos corredores e sua integração com o tecido urbano, bem como apresentados alguns exemplos de infraestruturas, de maneira a implementar o desempenho dos importantes elos de conectividade que existem na área, podendo, assim, garantir uma maior eficiência da Reserva da Biosfera do Cinturão Verde de São Paulo.

PALAVRAS-CHAVE. Planejamento Ambiental, Corredores Ecológicos, Ecologia da Paisagem, Estrutura Ecológica da Paisagem, Infraestrutura Verde, Planejamento Ecológico da Paisagem, Reserva da Biosfera do Cinturão Verde de São Paulo (RBCV). 


\section{ABSTRACT}

Here is presented a proposal for the development of ecological corridors in the western sector of the São Paulo Metropolitan Region Green Belt Biosphere Reserve (RBCV). This area was delimitated under the methodology and goals of the UNESCO's Man and Biosphere Program. This area of the Metropolitan Region of São Paulo already have a number of legal instruments and some conservation areas that are of extreme importance for the maintenance of ecological services for the Region. Between them there are fragments of Atlantic Forest in various succession stages, but under stress of further fragmentation and loss of habitats. They are until now providing ecological flows, both for biodiversity and water resources, all fundamental to the wildlife preservation and quality of the human life. This thesis aims to present the ecological corridors system obtained, that leads to discuss the conflicts, barriers and opportunities that could be taken in order to keep and enhance the flows of the ecological system in this track of the RBCV, through a landscape ecology and planning approach, with the indication of the landscape designs that could deal with the most challenging of these conflicts. The system design was based on ecological assessments of the existing landscapes, indicating areas with the more high relevance for ecological processes and connectivity. Assessments were made through the use of matrix and thematic mapping overlays. In this process, we went from the scale of regional planning to a Master Plan of a local development, which originates from the main corridor swath. We got the general layout of corridors that came out from this design process. It indicated areas with the greatest potential for conducting ecological flows, defining the main conflicts and barriers to the movements of animals and finally, allowed the delineation of the possibilities for the corridors implementation and its integration with the urban fabric and the infrastructure network that cross the whole area. The ecological and land-use and landscape information gathered could be preliminarily processed to indicate the most significant natural elements that remains, and the new elements that should be added through landscape planning and design, that could be integrated in order to resolve the barriers and conflicts, that are restraining the performance of the crucial links that can give to the RBCV its needed full implementation.

KEY WORDS: Environmental Planning; Ecological Corridor; Landscape Ecology; Landscape Ecological Structure; Green Infrastructure; Landscape Ecological Planning; Green Belt Biosphere Reserve (RBCV). 


\section{INTRODUÇÃO}

Se por um lado é consenso entre planejadores urbanos, e outros profissionais envolvidos com a administração pública, a necessidade do bom funcionamento das áreas metropolitanas, o mesmo não acontece quanto à forma de colocá-la em prática. O desenvolvimento de estudos e projetos na escala das áreas metropolitanas é proporcional aos desafios e problemas que acarreta.

Quando feito sem planejamento e de modo irregular, o crescimento urbano traz sérias implicações aos ecossistemas locais, além de causar inúmeras alterações que geram impactos ambientais negativos, como impermeabilização dos solos, processos erosivos, alterações no microclima, assoreamento, colmatagem e poluição dos rios e córregos, assim como poluição atmosférica, dentre outros (LEITE, 2008).

No caso das cidades brasileiras, são extensas as implicações e as perspectivas para estudos e análises relativos aos processos de expansão urbana e de periferização, relacionadas aos desdobramentos e impactos ambientais, já que a velocidade das transformações dos elementos naturais, nessas situações, ocorre de maneira intensa, veloz e muitas vezes de dificil e custosa reversão.

Apesar de a ocupação urbana, bem como em processo de urbanização, e a manutenção da biodiversidade ainda ocorrerem por meio de ações mutuamente exclusivas, alguns trabalhos de planejamento territorial mais recentes reconhecem a ecologia urbana como uma disciplina separada, colocando assim maior ênfase na manutenção da biodiversidade desses ambientes (HELLMUND, 2006). Nesses trabalhos, as áreas de vegetação em locais urbanos são vistas como grandes desafios de manejo para os profissionais preocupados com a biodiversidade, e não apenas como terrenos baldios biologicamente pouco significativos, de pouca importância socioeconômica ou destinados apenas ao lazer. 
Avistada por meio de imagens aéreas (vôo de pássaro), a Região Metropolitana de São Paulo (RMSP), a quarta maior metrópole do mundo, com quase 20 milhões de habitantes, apresenta elementos naturais como rios e córregos, vegetação, topografia sobrepostos por uma diversidade de usos sociais pela população que habita seus 39 municípios. Tal densidade de ocupação destaca a tensão presente em torno das áreas não ocupadas, tanto as mais como as menos extensas, os espaços abertos, muitos deles com seus destinos incertos e com ausência de regulamentação.

Como resultado de tamanho crescimento, a RMSP concentra grande parte da economia brasileira, o que garante à região inúmeros atrativos para investidores e, consequentemente, a centralização do comando do grande capital privado. Nela se encontra a maioria das sedes brasileiras dos mais importantes complexos industriais, comerciais e, principalmente, financeiros, que controlam as atividades econômicas no país. Com isso, surgiu na região uma série de serviços sofisticados, relacionados pela dependência da circulação e transporte de informações, como: planejamento, publicidade, marketing, seguro, finanças e consultorias, entre outros. O setor imobiliário é também atualmente uma atividade econômica intensa, com inúmeros projetos em execução de empreendimentos (horizontais e verticais) residenciais e comerciais.

Paralelamente, tem havido também a desindustrialização em alguns setores da região, especialmente na cidade de São Paulo - processo que passa a ocorrer a partir da década de 1980 e se intensifica na de 1990. Devido à densificação da cidade, as áreas industriais ficaram congestionadas e houve a valorização dos terrenos industriais, com o consequente aumento dos impostos territoriais. Isso levou ao desestímulo para a realização da atividade industrial e muitas empresas migraram para o interior e até mesmo para outros estados (MEYER; GROSTEIN; BIDERMAN, 2004).

Com relação à ocupação urbana, desde o início do século XX, e de modo mais intenso, vem 
predominando na RMSP o modelo de expansão horizontal e periférica, acomodando contingentes populacionais cada vez mais expressivos e promovendo a ocupação sem planejamento das franjas metropolitanas (MEYER; GROSTEIN; BIDERMAN, 2004). Dentre as áreas que deram suporte a essa expansão predatória, podem ser destacadas aquelas de grande importância ecológica e ambiental, como a Área de Proteção aos Mananciais, as Áreas de Proteção Ambiental (APAs) e as Unidades de Conservação correlatas, bem como as áreas não edificadas situadas ao longo de corpos d'água ou em encostas com grande declive (SILVA, 2004).

O crescente processo de especulação imobiliária ${ }^{1}$ na RMSP vem promovendo um crescimento intenso de investimentos. Nesse complexo processo de valorização do solo e crescimento urbano, acompanhado de forte exclusão econômica e social das camadas de baixa renda da população, os elementos naturais, como fragmentos florestais, nascentes e todo o sistema hídrico, bem como toda a fauna são ainda mais excluídos, menos considerados e amparados nas tomadas de decisões. Com isso, acabam sendo afetados profundamente, comprometendo a dinâmica ecológica geral da região e a viabilidade de muitas espécies.
${ }^{1}$ Sabemos que especuladores não apenas "preveem", mas também direcionam o "futuro" utilizando os mais diversos meios; assim, a especulação acaba não apenas acompanhando como também moldando, na maior parte das vezes, o caótico processo de transformação do espaço. Informações obtidas en http://www.usp.br/fau/docentes/ depprojeto/c_deak/CD/4verb/ espec-im/index.html. Acessado em 06/03/2012 


\section{CORREDORES ECOLÓGICOS}

Como vimos, o rápido avanço da ocupação da periferia da RMSP por assentamentos humanos que descumprem a legislação ambiental e urbanística traz consigo inúmeros impactos, com a alteração significativa do meio biofísico. Crescem em número os processos de degradação do solo e das águas, devido aos desmatamentos e deslizamentos de encostas, provocando assoreamento dos rios e, consequentemente, inundações e demais situações de risco e de perda de qualidade de vida para os moradores de toda a metrópole.

Muitos instrumentos legais e políticos atuam nesse tema buscando a ordenação da ocupação urbana frente às áreas ambientalmente frágeis. Podemos citar a Lei da Mata Atlântica, o Código Florestal, a Política Nacional do Meio Ambiente, o Plano de Bacia do Alto Tietê, a Lei de Lehman, a Lei do Código de Obras, os Planos Diretores Municipais, as Resoluções do Conselho Nacional do Meio Ambiente (CONAMA) e da Secretaria Estadual do Meio Ambiente (SMA), a Reserva da Biosfera do Cinturão Verde de São Paulo, dentre outros.

A vegetação que abrange as áreas florestais da região faz parte do grupo de Floresta Pluvial Tropical do Domínio da Mata Atlântica, sendo que a totalidade de sua área, originalmente, era recoberta por Floresta Ombrófila Densa Montana (VELOSO e LIMA, 1997). A área florestal regional constitui uma área de transição entre a Floresta Ombrófila (Floresta Atlântica) e a Floresta Mesófila Semidecidual do interior do Estado, com predominância de elementos da Mata Atlântica (MANTOVANI, 2005). A supressão da vegetação nativa foi decorrente de atividades agrícolas e urbanas, ao longo de séculos, sendo a atual existente caracterizada como vegetação secundária.

Figura de proteção ambiental reconhecida internacionalmente pela Organização das Nações 
Unidas para a Educação, a Ciência e a Cultura - (UNESCO), a Reserva da Biosfera do Cinturão Verde de São Paulo (RBCV) é parte integrante da Reserva da Biosfera da Mata Atlântica e foi criada em 1994, numa área de biomas de Mata Atlântica e de Cerrado, abrangendo 78 municípios, numa área de 1.611.710 ha. O objetivo principal de sua criação é conservar e restaurar os corredores ecológicos com diversidade biológica.

Nesta perspectiva, este estudo representa um ensaio para aplicação do método de avaliação paisagística $^{2}$ e do delineamento de corredores ecológicos por meio de um recorte ${ }^{3}$ entre três áreas de conservação principais e para além delas, localizadas na RBCV. A intenção é contribuir para a discussão de como deve ser o território, e não resolver todas as questões envolvidas no uso do solo, já que existem muitos outros interesses que interferem nesse planejamento, como a necessidade de habitação, de circulação, meios de transporte, saneamento básico, existência de núcleos de desenvolvimento econômico, de serviços de saúde e educação - todos fundamentais para o desenvolvimento da sociedade e para a vida das pessoas.

Os corredores ecológicos são importantes não apenas para o setor Oeste da RMSP, como para toda a região, pois reforçam a importância da estrutura ecológica e da infraestrutura verde, de maneira a se manter as funções ecossistêmicas da paisagem, que são fundamentais. Os animais levantados e elencados representam "bandeiras" que trazem consigo o beneficiamento de diversos outros indivíduos e elementos que garantem a sustentabilidade e habitabilidade da região.

Um sistema de corredores, delineado a partir de um minucioso processo de planejamento ecológico relacionado à dissolução de conflitos e otimização dos benefícios existentes nas paisagens, quando implementado, torna-se um importante organizador de uma série de vantagens, como: otimização do uso de recursos naturais; auxílio ao ordenamento do território; tentativa de frear a
${ }^{2}$ Neste trabalho, a paisagem é entendida como território - elemento dinâmico, fruto de diversas interações e percepcões.

${ }^{3}$ Foi feito um estudo das relações espaciais entre as áreas detentoras de valor ecológico, as quais são importantes para a manutenção e melhori dos fluxos ecológicos. 
ocupação de áreas com valor ecológico alto, evitando desastres naturais, e de adaptação às mudanças climáticas, fornecendo maior resiliência aos ambientes urbanos.

Antes de darmos início a uma abordagem como esta, foi preciso verificar a viabilidade de implementação, já que na área de abrangência do estudo, metropolitana e vasta, com $1216 \mathrm{~km}^{2}$, com distintos usos e características bem heterogêneas, periurbana, com inúmeras rodovias e conflitos, a proposta não é facilmente apreendida.

As áreas que receberam maior atenção se destacam não apenas por serem detentoras de valor ecológico, mas por se constituírem como oportunidades para os municípios se apropriarem desse patrimônio, não sendo transformados apenas em mais uma vasta periferia, árida, com canteiros centrais de avenidas e suas praças sem vida, estéreis, e sim em locais com estratégias mais "verdes", promotoras de serviços ambientais, atraentes, diferenciadas e com qualidade de vida para todos.

\section{HIPÓTESE E QUESTIONAMENTOS DA PESQUISA}

Apesar de toda a legislação existente, a expansão urbana da RMSP continua a avançar sobre as áreas previstas de proteção, inclusive aquelas abrangidas pela Reserva da Biosfera do CinturãoVerde de São Paulo que ficam expostas à destruição das áreas naturais e sua fragmentação.

Diante dessa situação, formulamos a seguinte hipótese: a partir da verificação e entendimento dos elementos naturais da paisagem, é possível concretizar o conceito de um sistema de corredores ecológicos em uma área metropolitana, de acordo com suas características periurbanas.

Para testá-la, definimos uma série de questões principais, as quais buscamos esclarecer ao longo dos capítulos. 
Dando início ao trabalho de pesquisa, perguntamos: o zoneamento atual empregado na área da RBCV, composto por Zonas Núcleos, Zonas Tampão, Zonas de Transição (IF, 2011), é suficiente para a proposta da reserva de conservação e restauração dos corredores ecológicos? Podemos avançar em uma metodologia de avaliação ecológica da paisagem de modo a resgatar os elementos naturais essenciais e que possam contribuir com o zoneamento e a gestão da reserva?

A primeira parte do trabalho foi direcionada para a avaliação do cenário atual do trecho estudado, de forma a esclarecermos e discutirmos essas questões.

Mas outros questionamentos surgiram: seria possível aplicar o conceito de corredores e conectividade, provenientes da ecologia da paisagem, nesta escala de planejamento e neste trecho selecionado da RMSP? Os processos ecológicos poderiam ser mantidos, mesmo com a ocupação urbana continuando a exercer pressão sobre as áreas de proteção?

Passamos a discutir, então, as estratégias de planejamento e os projetos dos novos espaços urbanos espaciais que podem ser utilizados para otimizar ou equilibrar a dualidade existente entre os processos ecológicos e sociais da urbanização. Dessa forma, buscamos determinar tais pontos/ áreas que correspondem aos conflitos e barreiras ao sistema de corredores, e discutir a viabilidade de implantação deles; ou seja, áreas que serviriam às funções de abrigo e proteção de habitats como os trampolins ecológicos, corredores contínuos e área ao longo de cursos d'água. Tudo isso com base em instrumentos conceituais e técnicos como: Sistema de Informações Geográficas (SIG), Unidades da Paisagem, Estrutura Ecológica, Infraestrutura Verde da Paisagem, buscando empregá-los nos processos de projeto de um cenário alternativo.

Importante frisar que a matriz tratada nesta paisagem, objeto de estudo, é composta por uma estrutura urbana heterogênea com diversos graus de adensamento e consolidação. Assim, 
continuamos a questionar: como deveria ser pensada a urbanização e requalificação urbana para responder à manutenção e implantação da estrutura ecológica? Quais instrumentos e ferramentas de planejamento urbano devem ser discutidos para serem agregados aos conceitos e princípios de ecologia da paisagem, norteadores desta investigação?

\section{OBJETIVO GERAL}

O objetivo geral desta pesquisa foi verificar a eficácia do zoneamento proposto da Reserva da Biosfera do Cinturão Verde como instrumento de gestão dos recursos naturais existentes para a manutenção de padrões e processos ecológicos no trecho selecionado.

\section{Objetivos específicos}

Os objetivos específicos foram:

1)Definir áreas com maior importância ecológica e ambiental, por meio de avaliações da paisagem realizadas durante o estudo;

2)Selecionar possíveis traçados (larguras, desenho, composição, uso) para a conformação dos corredores, a partir da situação urbana de cada trecho

3)Elaborar um cenário alternativo que aperfeiçoe as funções ecológicas estudadas, considerando aspectos como hidrologia, biodiversidade e áreas com potenciais para desenvolvimento urbano;

4)Avaliar o cenário desejável final verificando o grau de atendimento para melhor eficiência do setor da Reserva da Biosfera do Cinturão Verde de São Paulo;

5)Contribuir para novas estratégias e diretrizes no planejamento urbano e regional, com um delineamento multiescalar de um sistema de corredores ecológicos, de forma que a gestão dos elementos naturais da área de estudo seja compatível com o desenvolvimento urbano. 


\section{MATERIAS E MÉTODO}

Para a elaboração de planos e projetos de corredores ecológicos, empregamos a metodologia proposta por Hellmund $(2006,1993)$, que consiste em um processo composto por quatro etapas de planejamento e uma de manejo e gestão do sistema. Cada uma delas corresponde a uma escala diferente no processo de conformação de um corredor. Trata-se de um método capaz de auxiliar na identificação de importantes questões e indicar traçados para a proposição deste elemento nas paisagens estudadas, correspondendo a uma referência conceitual do tema discutido.

A primeira etapa sugerida por Hellmund (2006, 1993), corresponde à compreensão do contexto regional onde pretendemos criar o sistema de corredores. É o partido inicial do projeto, que, neste estudo, significa estar inserido na parte periurbana da Reserva da Biosfera do Cinturão Verde de São Paulo e representa a viabilidade geral que a área escolhida oferece para o estudo.Verificamos, então, se o sistema de corredores é adequado para a região, se tem relevância, considerando as principais áreas do ponto de vista ecológico, como também a rede hídrica e seus principais rios e afluentes. Observamos ainda o grau de fragmentação, os zoneamentos, as políticas ambientais e o poder público que incidem na área, bem como os gestores. Também foram formuladas questões relativas ao desenvolvimento, como os indutores de crescimento, seus principais problemas e limitações.

Na segunda etapa, definimos a área de abrangência do estudo. De acordo com a metodologia de referência, a proposta aqui é a seleção dos objetivos a serem alcançados com o desenvolvimento do projeto, bem como a definição geográfica da área de estudo. Para tanto, fizemos o mapeamento temático, com sobreposição de mapas e cruzamentos de informações, essencial nesta etapa, sendo que os resultados começaram a nos direcionar para o enfoque principal do sistema de corredores. É 
recomendado que as demandas de uso e implicações dos corredores sejam explicitadas de um modo bem objetivo. A delimitação das unidades de conservação, áreas com qualidade ambiental/ecológica e interesse de habitats, rotas de movimentos de fauna (localização de quando se tem acesso a estas informações), podem ser agregadas neste momento do estudo. Também identificamos os conflitos agressores da paisagem natural e sua localização.

Na terceira etapa, elaboramos o desenho macro e as faixas indicativas do sistema de corredores, com a identificação de pontos e trechos de maior conflito. Importante aqui manter a atenção para que se possa apreender a paisagem de uma maneira mais concreta. A identificação das faixas de corredores mais relevantes, ou seja, aquelas que englobam elementos naturais, é fundamental para a escolha de quais delas farão parte do sistema, sendo que, dependendo da situação, podemos obter desde uma faixa grande contínua, como pequenas porções de terra que poderão conformar um corredor.

A quarta etapa é dedicada à seleção dos desenhos, alinhamentos e larguras dos corredores. Os usos pretendidos e indispensáveis, as demandas em conjunto com detalhes e situações locais auxiliam na definição desse desenho e de suas bordas. Assim, bordas mais precisas são desenhadas a partir das faixas indicativas anteriormente definidas.

A quinta etapa proposta pelo autor representa a implementação e o manejo do sistema de corredores, que não fizeram parte do âmbito da pesquisa.

A metodologia de referência em trabalhos portugueses, fundamentada no conceito de Estrutura Ecológica da Paisagem (MAGALHÃES, 2007) foi também empregada, em conjunto com o conceito de Unidades da Paisagem (SALINAS, 1991). Concomitantemente, seguimos a metodologia de investigação de paisagens, sugerida pelos arquitetos paisagistas norte-americanos Steinitz (1990) 
e Steiner, (2000) e Lyle (1985), que trouxeram um suporte essencial para a composição de uma Estrutura Ecológica da Paisagem da área estudada.

Realizamos também a coleta de informações e material iconográfico na mídia impressa, em especial em revistas especializadas, sites, bibliotecas da Universidade de São Paulo, Universidade Técnica de Lisboa, Universidade Autônoma de Barcelona, Empresa Paulista de Planejamento Metropolitano (EMPLASA) e Instituto Florestal de São Paulo (IF). Os seguintes dados foram incorporados à pesquisa:

-EMPLASA (2007): Fotografias Aéreas Ortorretificadas - Ortofotocartas, na escala 1:5000, com data de voo de 2007.

•EMPLASA (2006): Cds 01, 02, 03 e 04. Base Cartográfica do Uso do Solo e Temática da Região Metropolitana de São Paulo.

•FUNDAÇÃO FLORESTAL - FF (2009) - Shapefiles das Unidades de Conservação nas Categorias de Proteção Integral e Uso Sustentável da RBCV, Limite do RBCV.

•INSTITUTO FLORESTAL - IF - (2010) Shapefiles dos limites das Unidades de Conservação, Inventário da Vegetação Natural e Rede Viária da RBCV.

Também coletamos informações em diversas fontes da legislação, sendo as mais significativas para este estudo:

-Agenda 21 local, documento municipal elaborado em parceria com a sociedade civil para a determinação de diretrizes para a integração de aspectos ambientais com outros aspectos do desenvolvimento, procurando a melhoria da qualidade dos ambientes urbanos e da qualidade de vida; -Código Florestal (Lei Federal no 4771, 15 de setembro de 1965, alterada pela Lei Federal nº 7803, de 15 de agosto de 1989); 
- Criação da Secretaria Municipal do Verde o do Meio Ambiente - SMVMA (Lei n 11.426, de 18 de outubro de 1993);

-Estatuto da Cidade (Lei Federal no 10.257, 2001), importante documento legal que define procedimentos de planejamento urbano e fornece algumas diretrizes para os Plano Diretores;

-Lei da Mata Atlântica (Lei no 11.428/064 e Decreto nº 6.660/08,5 que a regulamenta);

-Lei do Código de obras (Lei no 11.228, de 25 de junho de 1992);

•Lei Lehman (Legislação Federal nº 6766/79).

-Plano da Bacia do Alto Tietê (FUSP, 2002), aprovado pelo Comitê da Bacia Hidrográfica do Alto Tietê - CBH - AT (2003);

-Plano Diretor de Esgotos da Região Metropolitana de São Paulo (Revisado pela SABESP, 2003);

-Plano Diretor de Macrodrenagem da Bacia do Alto Tietê (1999);

-Plano Diretor Municipal de Barueri (Lei Complementar n. ${ }^{\circ}$ 150, de 10 de Dezembro de 2004)

-Plano Diretor Municipal de Caieiras (Lei Complementar 3.896 de 10 de Outubro de 2006)

- Plano Diretor Municipal de Cajamar (Lei Complementar nº 095 de 15 de Dezembro de 2007)

-Plano Diretor Municipal de Carapicuíba (Lei Complementar no 2.910 de 10 de Setembro 2009)

-Plano Diretor Municipal de Cotia (Lei Complementar nº 72 de 02 de Janeiro de 2007).

- Plano Diretor Municipal de Embu das Artes (Lei Complementar n 72 de Dezembro de 2003)

-Plano Diretor Municipal de Franco da Rocha (Lei Complementar Municipal nº. 618/2007 de 11 de Abril de 2007)

-Plano Diretor Municipal de Itapecerica da Serra (Lei 1.238 de 29 de maio de 2001)

-Plano Diretor Municipal de Jandira (Lei 1603 de 31 de Outubro de 2006.)

-Plano Diretor Municipal de Mairiporã (Lei Complementar n 297, de 06 de Novembro 2006). 
-Plano Diretor Municipal de Santana de Parnaíba ( Lei Complementar n o 30 de 2006)

-Plano Diretor Municipal de São Paulo (Lei nº. 13.430, de 13 de Setembro de 2002)

-Plano Diretor Municipal de Taboão da Serra (Lei Complementar no 132 de 26 de Dezembro de 2006com as alterações da Lei Complementar 164 de 24 de abril de 2008).

-Plano Diretor Municipal de Vargem Grande Paulista (Lei Complementar n ${ }^{\circ} 014$ de 12 de Dezembro de 2003).

-Política Estadual de Recursos Hídricos (Lei n 7.663, 1991);

-Política Estadual de Saneamento (Lei Estadual n 7.750);

-Política Nacional de Recursos Hídricos (Lei Federal no 9.433, 1997), responsável pela criação do "Sistema Nacional de Gerenciamento de Recursos Hídricos" e "Comitês de Bacias Hidrográficas";

-Política Nacional do Meio Ambiente (Lei Federal nº 6.938, 1988);

-Resolução do CONAMA (Resolução n 10, de $1^{\circ}$ e outubro de 1993 e Resolução nº 1, de 31 de janeiro de 1994);

-Sistema Nacional de Unidades de Conservação da Natureza - SNUC (Lei nº 9.985, de 18 de julho de 2000);

-Lei da Reserva Florestal do Morro Grande, no. 1949 em 4 de Abril de 1979;

-Lei da Reserva Florestal do Morro Grande, no. 1949 em 4 de Abril de 1979.

Todo o material obtido foi sistematizado. As Fotografias Aéreas Ortorretificadas (Ortofotocartas) disponibilizadas pela EMPLASA, na escala 1:5000, com ano de voo de 2007, serviram para a montagem inicial de um fotomosaico das áreas de estudo e para o reconhecimento delas. Optamos por trabalhar com dados georreferenciados, o que facilita a análise subsequente e a caracterização das áreas, os quais foram agrupados em uma base de dados através do software ArcGIS 9.3 (ESRI), sendo utilizado o referencial geodésico - projeção UTM (Universal Transversa de Mercartor), Fuso 23, South American Datum 1969 -SAD 69. 
A Base Cartográfica do Uso do Solo, a Temática da Região Metropolitana de São Paulo (EMPLASA, 2006) e as Fotografias Aéreas Ortorretificadas (EMPLASA, 2007) foram utilizadas em suas bases georreferenciadas para o mapeamento e investigação posterior. $O$ aplicativo gratuito Google Earth foi utilizado inúmeras vezes para conferência de alguns dados, pela facilidade de acesso e, principalmente, por ser mais atualizado do que a base da EMPLASA, de 2006 e 2007.

Com os dados, produzimos mapas temáticos para ilustrar as informações recolhidas, sendo o total de 31 mapas apresentados em formato A4, paisagem. A escala de trabalho variou em cada etapa da análise. Na primeira etapa, a regional, o mapa foi elaborado em 1:510.000 ( Mapa 1); a avaliação da supressão da vegetação e o mapeamento do uso do solo em quatro décadas foram realizados na escala de 1:300.000 (Mapa 4 ao 7). O mapeamento temático, as primeiras análises e a síntese do sistema macro de corredores foram realizados em 1: 140.000 (Mapa 8 ao 22), sendo que os procedimentos das análises da morfologia natural da paisagem foram sintetizados no Quadro 1 a seguir. Em seguida, a abordagem teve um maior detalhamento, e o eixo principal dos corredores, por ter um tamanho maior, foi tratado com uma escala menor, pela padronização do tamanho dos mapas. Assim, houve variações na etapa de análises, de 1: 80.000 (Mapa 24) e de 1:40.000 (Mapas 25 e 26). Na última etapa, as escalas utilizadas foram: 1:65.000 (Mapa 27), 1:50.000 (Mapas 28 e 29); 1:55.000 (Mapa 30) e 1:40.000 (Mapa 31).

Ainda sobre os mapas, quando possível, consideramos residuais as áreas inferiores a $0,01 \mathrm{~km} 2$; ou seja, definimos estas como a unidade mínima cartografável. 
QUADRO 1 - Síntese dos procedimentos utilizados para a determinação e desenho da Morfologia Natural da Paisagem, parte da Estrutura Ecológica Fundamental.

\begin{tabular}{|c|c|c|c|}
\hline \multicolumn{2}{|r|}{ FASES } & CARACTERIZAC̣ÃO & \multirow[t]{2}{*}{ OPERAC̣ÕES REALIZADAS } \\
\hline 1 & $\begin{array}{l}\text { Georreferenciamento do } \\
\text { Zoneamento RBCV (TIFF) }\end{array}$ & $\begin{array}{l}\text { Inserção de Sistema de } \\
\text { Coordenadas - Projeção UTM } \\
\text { (Universal Transversa de } \\
\text { Mercartor), Fuso 23, South } \\
\text { American Datum 1969 -SAD } 69 . \\
\text { em Figura Tiff. }\end{array}$ & \\
\hline 2 & Altimetria & $\begin{array}{l}\text { Curva Mestra de } 125 \mathrm{~m} / \text { Curvas } \\
\text { Auxiliares de } 25 \mathrm{~m} .\end{array}$ & $\begin{array}{l}\text { Correção da continuidade } \\
\text { das linhas. } \\
\text { Remoção de excessos. }\end{array}$ \\
\hline \multirow{2}{*}{3} & \multirow[t]{2}{*}{ MDT } & $\begin{array}{l}\text { TIN - valores de altitude } 700- \\
1200 \mathrm{~m}\end{array}$ & $\begin{array}{l}\text { ArcGis } 9.3[3 \mathrm{~d} \text { Analyst }[/ \\
\text { Create TIN. }\end{array}$ \\
\hline & & MDT com pixel de $25 \times 25 \mathrm{~m}$ & $\begin{array}{l}\text { ArcGis } 9.3 \text { [Spatial Analyst[/ } \\
\text { Convert to GRID. }\end{array}$ \\
\hline 4 & Hipsometria & $\begin{array}{l}\text { GRID com valores de altitude } \\
\text { com variações de } 50 \mathrm{~m} .10 \\
\text { classes foram incluídas numa } \\
\text { variação de } 700 \mathrm{~m} \text { até } 1200 \mathrm{~m} .\end{array}$ & $\begin{array}{l}\text { rcGis } 9.3 \text { [Spatial Analyst[/ } \\
\text { Convert to GRID_eleva- } \\
\text { tion/Reclassify. }\end{array}$ \\
\hline \multirow{3}{*}{5} & \multirow{3}{*}{ Declividade } & $\begin{array}{l}\text { Inclinação do terreno }(\%)- \\
\text { pixel } 25 \times 25 \mathrm{~m}\end{array}$ & $\begin{array}{l}\text { ArcGis } 9.3 \text { [Spatial Analyst[/ } \\
\text { Derived SLOPE }(\%)\end{array}$ \\
\hline & & $\begin{array}{l}\text { Classes de Declive } \\
\text { Reclassificação em } 5 \text { interva- } \\
\text { los: } 0-5 \% ; 5,1-15 \% ; 15,1-30 \% \text {; } \\
30,1-40 \% \text { e }>40 \%\end{array}$ & $\begin{array}{l}\text { ArcGis } 9.3 \text { [Spatial Analyst[/ } \\
\text { Reclassify }\end{array}$ \\
\hline & & $\begin{array}{l}\text { Classes de Declive } \\
\text { Reclassificação em } 2 \text { interva- } \\
\text { los: } 0-5 \% \text { e }>5 \%\end{array}$ & $\begin{array}{l}\text { ArcGis } 9.3 \text { [Spatial Analyst[/ } \\
\text { Reclassify }\end{array}$ \\
\hline \multirow[t]{2}{*}{6} & Linhas d'água & $\begin{array}{l}\text { Formato vetorial - EMPLASA, } \\
\text { (2006). }\end{array}$ & $\begin{array}{l}\text { Correção da continuidade das linhas. } \\
\text { Inserção de novas linhas d'agua a partir da } \\
\text { morfologia do terreno pela altimetria. }\end{array}$ \\
\hline & Linhas de Festo & Formato vetorial & $\begin{array}{l}\text { Delimitação manual das linhas em } \\
\text { AutoCAD } \\
\text { (3DPolyline) }\end{array}$ \\
\hline
\end{tabular}


Para obter os resultados sobre a Supressão da Vegetação, o procedimento realizado foi bastante específico. As imagens para a realização do uso do solo (material empregado especialmente nesta análise) foram adquiridas junto ao Instituto Nacional de Pesquisas Espaciais (INPE) dos satélites da família Landsat (1, 5 e 7), sendo selecionadas as cenas que recobririam o polígono envolvente da área a ser mapeada.

Selecionamos imagens de quatro datas diferentes, a saber: 27/05/1975; 19/06/1986; 28/06/1995 e 04/05/2010, de modo a permitir uma amostragem em cada uma das décadas que possuíam imagens disponíveis. Também buscamos concentrar a seleção nos meses com imagens disponíveis para todos os anos.

Para correção geométrica e processamento dos dados, optamos pelo programa Integrated Land Water Information System (Ilwis) desenvolvido pelo holandês Faculty of Geo-Information Science and Earth Observation of the University of Twente (ITC), de uso livre (disponível em http://www.itc. nl/ilwis/downloads/ilwis33.asp )

Foi necessária, ainda, para a correção geométrica das imagens adquiridas, a obtenção de uma base cartográfica auxiliar na realização do novo georreferenciamento. A base escolhida foi o sistema viário da Região Metropolitana de São Paulo em formato shapefile, publicado pela EMPLASA (2006) e já empregado em outras etapas do trabalho.

As imagens de satélite possuem distorções sistemáticas resultantes do processo de aquisição e imprecisão dos dados de posicionamento da plataforma (D’ÁLGE, 2001). Para corrigi-las, realizamos um novo georreferenciamento utilizando o software Ilwis a partir da base cartográfica da RMSP, de modo que todas as imagens ficaram com o mesmo referencial geodésico utilizado no trabalho.

Para uniformização da unidade mínima cartografável (pixel) (procedimento necessário já que as imagens são multitemporais e apresentam pixels variando entre 30 e 90 metros), as imagens foram reamostradas, resultando em imagens uniformes com pixels de 30 metros. 
Em seguida, realizamos o realce de contraste tendo como base seu histograma, procedimento que visa melhorar a qualidade da imagem, permitindo uma melhor discriminação dos objetos nela presentes (INPE, s/d); ou seja, torna mais fácil o reconhecimento de padrões de uso e ocupação do solo.

Em uma primeira fase, a interpretação das imagens orbitais se baseou nos elementos clássicos da fotointerpretação definidos por padrões específicos; são eles:

• Cores: variação de acordo com a composição colorida. Para este trabalho, realizamos uma composição colorida das imagens de modo a facilitar a identificação dos padrões de uso, sendo a vegetação em tons de verdes, edificações e solo exposto variando em tons de vermelho e água em preto;

-Textura: variação da rugosidade da feição, da lisa à altamente rugosa;

-Tonalidade: brilho encontrado na área mapeada, variando do baixo ao muito alto;

-Forma: variação geométrica das feições identificadas na imagem, da regular a muito irregular.

Convencionou-se identificar as seguintes classes de uso e ocupação do solo:

-Área edificada: identificada na imagem em tons de vermelho e geralmente com forma geométrica bem formada;

-Solo exposto: variação de tons de vermelho com ou sem forma geométrica definida e rugosidade lisa;

-Áreas de floresta: tons de verde escuro, geralmente sem forma geométrica definida, exceto no caso de parques, e com bastante rugosidade;

-Áreas de reflorestamento: variando em tons de verde claro, geralmente com forma geométrica bem definida - talhões - e com baixa rugosidade;

-Áreas de campo: variação dos tons de verde, podendo apresentar ou não forma geométrica bem definida, e com rugosidade lisa;

•Corpos d'água: identificados através de corpos negros. 
Para a elaboração do mapeamento do uso do solo, adotamos o método da classificação supervisionada e o Classificador de Máxima Verossimilhança, uma das técnicas de classificação mais utilizadas dentro do sensoriamento remoto (SOARES et al., 2011; LUCHIARI, 2001; NOVACK et al., 2007), que consiste na criação de amostras como suporte para encontrar pixels similares e classificá-los como tal. No presente trabalho, o padrão de coleta foi de, no mínimo, 1.000 pixels para cada amostra, identificação esta feita de acordo com a habilidade visual do operador e obedecendo aos critérios já citados para identificação das classes de uso e ocupação do solo.

Após esses processos, iniciamos a classificação supervisionada do uso e ocupação do solo das imagens, sendo o produto resultante submetido a um filtro majoritário, de modo a suavizá-lo e dar a ele maior homogeneidade.

O método da classificação supervisionada possui limitações decorrentes da automação computacional dos processos, que o torna menos preciso que a classificação manual das classes; todavia, apresenta uma ótima relação custo/ benefício quando em grandes áreas de estudo.

Outra limitação foi a resolução espectral/espacial das imagens de 1975 (4 bandas e 90m, respectivamente) que impossibilitaram a separação das classes mata e reflorestamento para este ano.

Mesmo com todas essas questões, a metodologia aqui empregada serviu muito bem para diagnosticar o crescimento da mancha urbana nos últimos 35 anos, evidenciando a expansão do processo de adensamento urbano a partir dos vetores do sistema viário.

Já o material utilizado para a elaboração da lista de aves e mamíferos de maior porte com provável ocorrência para a área de estudo foi obtido por meio de revisão bibliográfica de levantamentos realizados nas áreas de influência da região estudada, sendo priorizados os que ocorreram em Unidades de Conservação municipais, estaduais ou federais (levantamentos publicados ou planos de manejo). Também foram utilizados dados dos levantamentos do Estudo de Impacto Ambiental do trecho Norte do Rodoanel, que constituiu informação importante para a elaboração do levantamento. 
Assim, consideramos relevantes os levantamentos realizados em sete áreas, que constituíram a base de informação para as espécies de animais apresentadas.

Na proposição das tipologias de ruas do município de Taboão da Serra, onde exemplificamos o uso de elementos de infraestrutura verde para minimização de conflitos decorrentes dos usos urbanos, utilizamos também o Manual Técnico de Arborização Urbana do Departamento de Parques e Áreas Verdes da Cidade de São Paulo - DEPAVE (2005), seguindo a Portaria Intersecretarial nº 05/ SMMA -SIS/ 02, de 27/06/2002. Respeitamos a recomendação da passagem de pedestres com, no mínimo, 1,20m, conforme a NBR 9050/944.

Seguimos as recomendações (DEPAVE, 2005) para a área da caixa de plantio de árvores viárias, sendo que o espaço em torno daquelas de pequeno porte deve ser de $2 \mathrm{~m}^{2}$ e de médio e grande porte, $3 \mathrm{~m}^{2}$.

Lembramos que a Portaria Intersecretarial no 05/SMMA recomenda que as calçadas que deverão receber arborização tenham uma largura mínima de $2,40 \mathrm{~m}$. Aquelas com larguras inferiores não são indicadas para a arborização saudável e sem conflitos com pedestres e outros elementos da infraestrutura urbana. Portanto, procuramos, nas propostas, aumentar a largura das calçadas nas tipologias, para que possam receber o plantio de espécies de grande porte.

O trabalho está estruturado em quatro capítulos e uma conclusão. No capítulo 1, "Bases Conceituais para a Conformação de um Sistema de Corredores Verdes", apresentamos a revisão teórica e o levantamento de experiências de estudos e projetos de temas similares em outras localidades, de forma a referenciar a proposta desenvolvida nesta pesquisa, fundamentar as hipóteses levantadas e visualizar a viabilidade e as dificuldades de se elaborar um plano da paisagem que possa promover um sistema de corredores ecológicos na área estudada.

Em seguida, o capítulo 2, "Abordagem Regional e Área de Abrangência do Estudo", traz alguns aspectos da área estudada, que demonstram e esclarecem a potencialidade e a oportunidade
${ }^{4}$ A Acessibilidade é definida pela ABNT- Associação Brasileira de Normas Técnicas, pela norma NBR 9050/94. 
de essa área se tornar objeto de um planejamento ecológico da paisagem. Abordamos também neste capítulo as políticas públicas relacionadas à gestão de recursos naturais da região selecionada, bem como descrevemos seus principais elementos naturais, como vegetação e fauna regional.

Após esse contexto regional, a análise foi direcionada para um determinado limite territorial, denominado área de abrangência do estudo. A partir deste momento, passamos a avaliar e mapear a área com mais detalhes acerca da paisagem, incluindo informações relacionadas às unidades administrativas e ao uso do solo. No final do capítulo, trazemos informações sobre o crescimento urbano ocorrido em detrimento da supressão da vegetação em quatro períodos: 1975, 1986, 1995 e 2010. Os mapas apresentados são: Mapa 01 - Área de Estudo inserida no limite Oeste na Reserva da Biosfera do Cinturão Verde; Mapa 02 - Unidades Administrativas e Sistema Viário; Mapa 03 - Uso do Solo; Mapa 04- Avaliação Temporal Crescimento Urbano, 1975; Mapa 05 - Avaliação Temporal Crescimento Urbano, 1986; Mapa 06 - Avaliação Temporal Crescimento Urbano, 1995; Mapa 07- Avaliação Temporal Crescimento Urbano, 2010; Mapa 08 - Supressão da Vegetação; Mapa 09 - Concentração do Crescimento Urbano.

O capítulo 3, "Identificação de Áreas com Potencial para o Estabelecimento de Corredores Ecológicos", é dedicado ao aprofundamento do conceito da Estrutura Ecológica da Paisagem e da Morfologia Natural da Paisagem. Buscamos também explorar e demonstrar os instrumentos conceituais e técnicos relacionados ao Sistema de Informações Geográficas (SIG) que foram empregados nos processos de avaliação da paisagem. Na segunda parte do capítulo, identificamos as Unidades da Paisagem, etapa fundamental para a busca de uma definição para os corredores. Com isso, obtivemos matrizes de cruzamentos de dados e novos mapeamentos que ajudaram a conformar um mapa síntese: “Áreas com Valor Ecológico", o que possibilitou a definição dos Corredores Ecológicos na escala de abrangência adotada. Os mapas elaborados foram: Mapa 10 - Altimetria; Mapa 11 - Hipsometria; Mapa 12- Modelo Digital do Terreno; Mapa 13 - Declividade; Mapa 14 - Rede Hídrica; Mapa 15 - 
Morfologia do Terreno; Mapa 16 - Unidades do Relevo; Mapa 17- Litologia; Mapa 18 - Unidades da Paisagem I; Mapa 19 -Vegetação e Áreas de Conservação; Mapa 20 - Valor Ecológico da Paisagem; Mapa 22 -Valores Ecológicos Baixo e Muito Baixo Vulneráveis a Deslizamentos e Inundações.

No capítulo 4, "Delineamento das Faixas de Estudo para a verificação da Implementação do Sistema de Corredores Ecológicos”, continuamos a análise da paisagem, mas agora procuramos delinear faixas por onde o sistema de corredores encontrou possibilidades de percorrer. Definimos bordas e limites dos eixos principais e faixas secundárias dos sistemas e detalhamos as possibilidades de implementação para os corredores nessas situações, de maneira que os limites puderam ser ainda mais bem definidos, os conflitos mais evidenciados e discutidos, além de algumas soluções apresentadas como possibilidades de implantação capazes de minimizá-los, viabilizando a existência de um sistema integrado de corredores verdes.

Os mapas apresentados foram: Mapa 23 - Potencialidades de Fluxos na Paisagem Natural; Mapa 24 - Hierarquização das Áreas de Interesse no Eixo Principal; Mapa 25 - Hierarquização das Áreas de Interesse nas Faixas 1, 2 e 3; Mapa 26 - Hierarquização das Áreas de Interesse nas Faixas 4 e 5; Mapa 27 - Possibilidades para Implementação dos Corredores /Eixo Principal - Setor 1; Mapa 28 - Possibilidades para Implementação dos Corredores /Eixo Principal - Setor 2; Mapa 29 - Possibilidades para Implementação dos Corredores /Eixo Principal - Setor 3; Mapa 30 Possibilidades para Implementação dos Corredores/ Faixa Secundária 1; Mapa 31 - Possibilidades para Implementação dos Corredores/ Faixa Secundária 3.

Finalizamos com as conclusões, sinalizando possibilidades de mudanças na área estudada, de modo a viabilizar os corredores ecológicos, garantindo assim contribuições para a Reserva da Biosfera do Cinturão Verde de São Paulo. 
BASES CONCEITUAIS PARA A CONFORMAÇÃO DE UM SISTEMA DE CORREDORES ECOLÓGICOS 


\section{BASES CONCEITUAIS PARA A CONFORMAÇÃO DE UM SISTEMA DE CORREDORES ECOLÓGICOS}

A revisão teórica e um levantamento de experiências de estudos e projetos de temas similares aqui tratados são apresentados no presente capítulo. A ideia é referenciar a proposta que foi desenvolvida na pesquisa, fundamentar as hipóteses levantadas e visualizar a viabilidade e as dificuldades de se elaborar um plano da paisagem que possa promover um sistema de corredores ecológicos na área estudada.

A partir de uma revisão de diversos autores da área de planejamento ecológico da paisagem, temos o conhecimento de várias iniciativas, desde meados do século passado, que procuraram integrar o processo de urbanização a condicionantes e processos naturais.

(MAGALHÃES, 2007; LEITÃO \& AHERN, 2006; FORMAN, 2004; NDUBISI, 2002; STEINER, 2000; TELLES, 1997; LYLE, 1985; MCHAR G, 1969).

O termo paisagem é envolvido por uma riqueza de conteúdos e acepções. Distintos períodos históricos e sociopolíticos propiciaram diferentes maneiras de apreendê-la, compondo as relações entre esta e o sujeito, as quais se refletem em uma diversidade de conformação, interação e composição do meio externo, seja ele espaço, território, lugar, ambiente ou paisagem. 
Essa designação pode também ser compreendida a partir de alguns conceitos provenientes de distintas áreas do conhecimento, como Geografia, Filosofia, Biologia, Ecologia ${ }^{5}$, Arquitetura e Planejamento da Paisagem, Estética, Artes Plásticas, dentre outras. Na presente abordagem, a paisagem é tratada em uma interface de conhecimentos que tangencia a Geografia, a Ecologia e a Arquitetura da Paisagem 6 .

Paisagem, nosso objeto de estudo, é entendida como um sistema dinâmico e complexo, composto tanto por fatores naturais quanto culturais. Trata-se de uma acepção que depende de uma escala de observação e de um observador para ser delimitada espacialmente. É a abordagem que o observador coloca diante da paisagem que a define e que também realça os seus componentes, os quais acabam por caracterizar a sua complexidade. Um pintor ou um fotógrafo que pretenda retratar um pôr do sol no horizonte se coloca diante da paisagem numa posição adequada, buscando encontrar a imagem e seus tons de cores até que se sinta satisfeito para compor sua obra. Um ecólogo da paisagem, para seu estudo de campo, precisa definir uma área que contenha elementos que possam contribuir com o tema escolhido e, assim, auxiliar na pesquisa desenvolvida. Por exemplo, para se estudar aves típicas de um ambiente estuarino, a paisagem deve conter ecossistemas específicos para a manutenção da espécie.

Compreendemos a paisagem, então, como uma área definida pelo observador para um propósito de investigação. Sendo assim, a que selecionamos para este estudo inclui aspectos principais que lhe são inerentes, de modo que o recorte, tanto espacial como referente à escala escolhida, direcionou-nos para os questionamentos e discussões aqui tratados. Nesse sentido, a escala de observação, tanto temporal quanto espacial, é a principal questão contida no conceito de paisagem, pois define os elementos que se consegue distinguir e apreender, bem como, consequentemente, distintos questionamentos e vetores que nela atuam.

São os elementos que compõem uma paisagem que conferem as características de seu padrão e as distinções existentes entre eles que promovem a sua heterogeneidade. Também os fluxos e as relações que se estabelecem entre os elementos físicos e biológicos da paisagem são fatores de interesse quando a definimos para uma investigação, e são os responsáveis pelos processos ecológicos nela existentes.

Nesta perspectiva, entendemos como vetores da paisagem as relações entre os padrões espaciais (p.g. tamanho, formato, quantidade) dos elementos que a compõe e os processos ecológicos (p.g. migrações, forrageamento, dispersão, floração, reprodução) (FORMAN, 1995). Numa abordagem da ecologia urbana, podemos inserir aos exemplos de processos da paisagem
${ }^{5}$ Para o ecólogo Metzger (2001:4), paisagem pode ser definida como: um mosaico heterogêneo formado por unidades interativas, sendo esta heterogeneidade existente para pelo menos um fator, segundo um observador e numa determinawda escala de observação.

${ }^{6}$ Para arquitetos e planejadores urbanos, é atribuída à paisagem a dimensão social em sua composição. Dessa forma, a paisagem é considerada, além de um objeto de análises e estudo, um objeto de propostas e projetos. 
aqueles relacionados a entradas de alimentos e materiais, balanço de oxigênio e gás carbônico, fluxos de energia e matéria, ciclos hídricos e biomassa vegetal (BARRACÓ et al., 1999).

Sabemos que a paisagem é também resultado das ações do homem sobre o espaço (SANTOS, 1999), por isso fruto de decisões políticas. Neste estudo nos apropriamos do conceito de paisagem, acima descrito, para avaliá-la e, assim, elaborarmos um plano de sistema de corredores ecolóogicos para uma região periurbana, de forma que não nos estenderemos nas discussões epistemológicas, políticas e sociais relacionadas às diversas definições e conceitos atribuídos ao termo.

\subsection{PLANEJAMENTO ECOLÓGICO DA PAISAGEM}

O planejamento territorial corresponde a uma atividade relacionada à transposição do conhecimento científico e técnico para as ações humanas, de modo que decisões possam ser tomadas acerca de cenários futuros. Corresponde a um processo rigoroso que visa imprimir racionalidade às ações e enfrentar situações de forma criativa (SANTOS, 2004).

Pela própria complexidade inerente ao objeto, devem ser atribuídos ao planejamento da paisagem procedimentos metodológicos pautados em fundamentos científicos e técnicos coerentes às suas dinâmicas.

O direcionamento de ações sobre o território, seja para viabilizar alterações, transformações, seja para se conseguir a conservação de elementos naturais, precisa ser precedido de métodos que analisem a paisagem, de modo a se elaborar um inventário de determinado ambiente em uma escala ampla de observação. Dessa forma, o procedimento envolve a interpretação de complexas interações que se estabelecem entre elementos heterogêneos entre si.

A atividade de planejar quais usos determinada localidade deverá abrigar, de um modo geral, é um processo contínuo composto pela coleta, organização e análise sistematizada das informações, por meio de procedimentos e métodos, para que se possa chegar a decisões ou escolhas acerca das melhores alternativas para o aproveitamento dos recursos disponíveis (SANTOS 2004).

Na maior parte das situações, a definição de um plano (de paisagem, cidade, estado, pais, etc.), de disposição e definição das atividades humanas, com suas diretrizes, propostas e mapeamentos, é permeada por contradições e conflitos de interesses. Por isso, além dos aspectos técnico-científicos, aqui mais discutidos, devemos considerar o seu componente político, composto tanto de vertentes institucionais, como os agentes responsáveis pelos instrumentos de gerências político-institucionais 
(licenciamentos, controle, fiscalização, aprovação de leis, gestão de políticas publicas), como de vertentes comunitárias, que são os atores com atuação e interesses representativos dos desejos e das necessidades da população.

O componente econômico, figura importante do planejamento territorial, possui também grande força geradora de conflitos, e também de soluções, sobre as demais abordagens e deve ser mencionado, destacando-se a atuação de consultores e investidores, que, em sua maioria, visam à obtenção de lucros e à garantia do sucesso operacional de seus empreendimentos, desconsiderando, muitas vezes, os demais componentes e atores ${ }^{7}$.

Também a participação da sociedade, o envolvimento de lideranças e maior integração entre planos de escala mais abrangente, sejam regionais, estaduais ou federais, são essenciais ao sucesso de todos os projetos para a paisagem, pois promovem uma discussão mais coesa, o que auxilia no equacionamento de divergência de interesses.

Nesta perspectiva, uma maneira de evitar que as intervenções sobre o espaço público e/ou privado sejam acessórias e paliativas é favorecer o envolvimento das pessoas que moram, trabalham, estudam, ou seja, que vivem no perímetro da área. O grande desafio é promover o interesse e a identificação desses cidadãos com as propostas e os espaços das intervenções, de modo que esse fazer coletivo, em conjunto com os demais atores envolvidos no processo, garanta um efeito duradouro sobre a paisagem (BARTALINI, LIMA e PALAMIN, 2005).

Já o planejamento ecológico da paisagem é uma área de aplicação de princípios e conceitos de ecologia, ecologia da paisagem e biologia da conservação dentro do processo de planejamento fisico-territorial de cidades e suas regiões, bem como em áreas rurais e pouco povoadas.

Para Pellegrino 2000:168

[O planejamento ecológico] busca a criação de uma solução capaz de manejar as mudanças dos elementos da paisagem, de forma que as intervenções humanas sejam compatibilizadas com a capacidade dos ecossistemas de absorverem os impactos advindos das atividades previstas e de se manter a integridade maior possível dos processos e ciclos vitais que ocorrem em seu interior.

Em seu modelo de planejamento ecológico, Steiner (2000) se refere a múltiplos objetivos contidos na prática, como abióticos, bióticos e culturais, os quais devem manter o foco na distribuição de uso do solo. Seu modelo corresponde a um procedimento que inclui onze etapas que envolvem o estudo de sistemas biofisicos e socioculturais de lugares e/ou paisagens para que
${ }^{7} \mathrm{O}$ estudo aqui apresentado pretende oferecer uma contribuição às discussões que envolvem o processo de planejamento ecológico regional de uma paisagem periurbana, metropolitana, sendo assim complexo e multi-temático, composto por diversos atores. Não se pretende abranger, com a presente discussão, todos os temas relacionados à criação de planos, tarefa que não seria fácil e fugiria da proposta. Consideramos de suma importância resgatar os elementos naturais presentes na paisagem, tantas vezes excluídos das discussões de planos e projetos (e muitas vezes destruídos), de forma a realçar a sua importância para a conformação de um plano integrado de áreas que oferecem importantes serviços ambientais, não só ecossistêmicos, mas também para toda sociedade, agregando mais um elemento para o processo de tomada de decisões. 
os usos sejam dispostos em seus locais mais apropriados. Trata-se de um modelo que enfatiza o estabelecimento de objetivos claros, a implementação, por meio da administração e da participação pública, realizada por uma educação contínua e pela participação civil em todo o processo de planejamento. O modelo pode ser considerado transdisciplinar porque envolve profissionais, especialistas e cidadãos em um processo bastante interativo.

Florez (1997) afirma que muito se discute entre planejadores e arquitetos da paisagem urbana, sobretudo a importância da preservação e conservação dos recursos naturais, mas que, diante desse paradigma ecológico, os conceitos e princípios essenciais da Ecologia permanecem pouco compreendidos dentro dessas áreas.

Johnson e Hill (2002) são bastante entusiásticos sobre a importância em estudar e tentar aplicar conceitos ecológicos em ações de planejamento e em arquitetura da paisagem. Os autores encorajam os planejadores e arquitetos a prestarem atenção nas possibilidades que existem de reconciliar o desenvolvimento humano com técnicas que mantenham a presença da natureza.

Nudbisi (2002) avança em uma síntese crítica sobre diferentes abordagens do planejamento ecológico da paisagem. Essas abordagens oferecem uma ampla visão das mudanças de valores das sociedades com relação aos recursos naturais sobre o território e promovem um corpo conceitual consistente, com dados e técnicas necessários para que as teorias sejam colocadas em prática pelos planejadores.

\subsection{CONTRIBUIC̣̃̃ES DA ECOLOGIA DA PAISAGEM}

Como destaca Turner (et al, 2001, a ecologia da paisagem colabora com muitos aspectos no contexto da ecologia aplicada, e vem demonstrando grande importância no desenvolvimento e na aplicação de métodos de manejo de ecossistemas. Porém, de acordo com a autora, essa aplicação ainda requer a integração e a síntese de muitos aspectos da disciplina, o que dificulta a extrapolação dos dados de estudos científicos para as atividades práticas.

O enfoque dos estudos dentro da ecologia da paisagem não apenas está centrado em quanto uma paisagem possui de um determinado elemento, mas também como ele está distribuído sobre a paisagem (TURNER, GARDNER e O’NELL, 2001).

A contribuição maior trazida pela ciência para a Ecologia é, portanto, o reconhecimento de que existe uma dependência espacial e interações entre as unidades de paisagem ${ }^{8}$, que acabam por interferir no funcionamento delas (METZGER, 2001).

${ }^{8}$ Unidades da Paisagem são unidades espaciais onde existe uma homogeneidade relativa quanto ao seu comportamento/características, constituindo uma síntese de um conjunto de componentes (SALINAS, 1991). 
Nesta perspectiva, a fragmentação e a conectividade são dois conceitos amplamente discutidos em estudos e pesquisas científicas em ecologia da paisagem e de fundamental importância para o planejamento ecológico da paisagem. São conceitos relacionados, pois, a partir da fragmentação de habitats e de ecossistemas, pode vir a ocorrer a perda de conectividade entre eles, comprometendo e inviabilizando, ao longo do tempo, a existência de populações.

A questão de conectividade e a utilidade de corredores que conectem remanescentes de florestas vêm recebendo uma crescente atenção na literatura e fomenta a indagação principal desta tese.

Já a fragmentação de habitats naturais corresponde à ruptura de suas áreas contínuas (FAHRIG, 1997; FAHRIG, 2003). Junto a esses processos, ocorre a própria perda de áreas de habitat e consequente redução no tamanho médio dos fragmentos, aumento do isolamento entre eles e também das áreas de contato entre habitat e não-habitat (efeito de borda ${ }^{9}$ ). Trata-se de um processo que resulta em diferentes configurações espaciais dos remanescentes na paisagem, pois o tamanho, formato e a posição dos fragmentos influenciam o estabelecimento de conexões entre os seres vivos.

Neste sentido, é importante considerar que algumas espécies requerem grandes áreas e outras, áreas menores. A partir de teorias de manejo ecossistêmico, quando o foco de observação são grandes remanescentes de florestas, a ênfase deve recair em manejar as dinâmicas ecológicas internas. Quando os estudos se centram nos fragmentos menores, o manejo deve ser direcionado, em primeiro lugar, para o controle das interferências externas. Isso significa que a conectividade, neste caso, possui uma importância muito grande e, assim, a tentativa de aumentá-la e fazê-la mais eficiente deve ser uma meta prioritária para as ações de planejamento e manejo dessas áreas.

A conectividade se relaciona com o espaço físico onde flora e fauna podem se mover entre fragmentos de vegetação ou entre diversos habitats. Para que ocorra conexão, é preciso que existam elos e ligações em escalas apropriadas. Os corredores são, justamente, um dos meios de se estabelecer conectividade.

Organismos se movem em uma faixa de escalas espaciais, que varia desde metros a centenas de quilômetros. Para se atingir a conservação da biodiversidade em paisagens transformadas pelas atividades humanas, são então necessárias medidas que mantenham a conectividade de espécies, comunidades e processos ecológicos em múltiplas escalas. A manutenção da conectividade precisa ser também abordada na escala temporal, para permitir que haja a disponibilidade e qualidade do habitat ao longo do tempo.

Como bem destaca Bennet (2003), os benefícios consequentes do reforço da conectividade
${ }^{9}$ Os efeitos de bordas mais comuns são: elevação a temperatura e luminosidade e redução de umidade (METZGER, 1999). 
correspondem a um aumento da capacidade dos animais para percorrer paisagens alteradas, mais oportunidades para a dispersão tanto de habitats isolados como de populações e maior probabilidade de continuidade dos processos ecológicos em paisagens fragmentadas. Os elos que promovem a conectividade da paisagem podem também ter um papel fundamental na dinâmica ecológica ao atuar como habitats de plantas e animais, bem como outras contribuições para outros processos ecológicos, como oferta de abrigo, alimento e área de vida.

Ainda segundo o autor, há também desvantagens na existência dessas ligações, que incluem seu potencial de disseminação de espécies invasoras, doenças ou distúrbios (como incêndios), podendo aumentar também a exposição dos animais a predadores, competidores ou parasitas. E há que se pensar, ainda, no risco de que os investimentos necessários para manutenção das ligações podem resultar em custo-benefício menos favorável do que se fossem empregadas outras medidas de conservação.

Numa paisagem, a conectividade para as espécies e comunidades de flora e fauna pode acontecer de algumas maneiras: por meio da implementação de um mosaico de distintos elementos da paisagem, seu manejo e implementação, de modo que variados ecossistemas possam garantir a sobrevivência e mobilidade das espécies, ou então por meio de trampolins ecológicos ou corredores contínuos, ambos compostos por habitats (BENNET, 2003)(Figura 1).

A definição da maneira mais apropriada para se estabelecer a conectividade, uma vez perdida ou enfraquecida, depende do tamanho e forma da modificação do habitat. Do ponto de vista da biota, a mais atrativa seria a de se tentar manejar a paisagem buscando-se transformar todo o mosaico num ambiente adequado à sobrevivência das mais diversas formas de vida, situação que apenas consegue ser eficaz onde existe uma densa e predominante cobertura florestal ou de ecossistemas preservados. Nesta situação, espécies mais tolerantes à alteração dos habitats podem ser beneficiadas por mosaicos mais heterogêneos, pois são menos sensíveis às alterações da paisagem (BENNET, 2003).

De outro modo, num contexto de uma matriz ${ }^{10}$ com um ambiente desfavorável e hostil, existem as espécies que são atraídas, na paisagem, apenas pelas manchas ${ }^{11}$ de
के

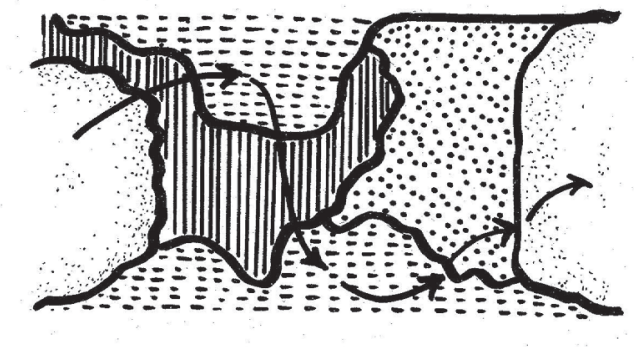

B
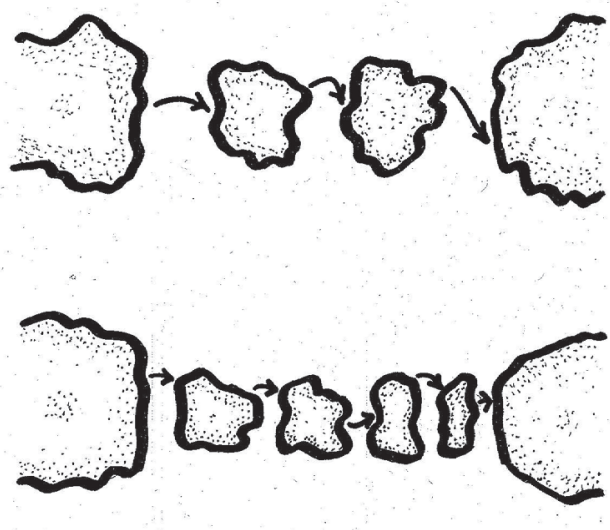

a

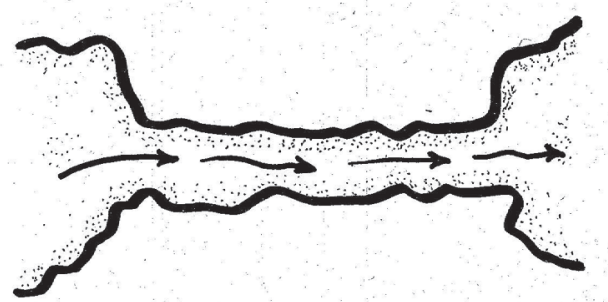

Figura 1 - Maneiras de se estabelecer a conectividade. a) Manejo de um mosaico de habitats para facilitar o movimento. b) e c) Manutenção de habitats específicos que permitam o deslocamento em ambientes hostis, sendo que este padrão pode ter a forma de trampolins ecológicos com variados tamanhos e distâncias (b) ou ser um corredor de habitat que fornece uma conexão continua (c). (adaptado de BENNET, 2003). 
habitats. Neste caso, a conectividade da paisagem depende de um corredor contínuo ou dos trampolins ecológicos, ambos formados por habitats mais atrativos e acolhedores que podem possibilitar aos indivíduos moverem-se sobre a matriz. Esta abordagem para se atingir a conectividade é fundamentada na identificação e no manejo de habitats específicos para a fauna.

\subsubsection{CORREDORES DE HABITATS}

Corredores são porções lineares de terra, que se diferenciam da área circundante em todos os seus lados (FORMAN, 1995). São também classificados como qualquer trecho identificado por espécies e utilizado por elas, de modo a facilitar os movimentos de fauna e flora, ao longo do tempo, entre fragmentos que outrora tenha ocorrido um bloqueio ou interrupção dos movimentos (HILTY; LIDICKER; MERELENDER, 2006). Os corredores podem ser compostos por diversos elementos, mas sempre têm como característica promover a conectividade entre dois deles que se encontram distantes.

A importância dos corredores nas paisagens se deve ao fato de, por meio da conectividade que propiciam, serem uma maneira de se manter populações em paisagens fragmentadas (FORMAN 1995; BENNETT, 2003).

Um corredor de habitat corresponde, portanto, a um contínuo de um ou mais habitats que beneficie o deslocamento da biota. Para que seja eficiente, deve promover uma ligação contínua, ou quase contínua, de habitats adequados em meio a um ambiente desfavorável. Tais corredores recebem diversas terminologias, como "corredores de fauna e flora", "corredores de dispersão" e "corredores de movimentos", estes conhecidos por serem utilizados por animais para se movimentarem (Harris; Scheck, 1991; Newmark, 1991; Simberloff et al., 1992; Noss, 1993 apud BENNET, 2003).
${ }^{10}$ Trata-se do elemento da paisagem que exerce a maior influência sobre os processos e as alteraçõe que nela ocorrem. É o elemento que circunda as manchas e os corredores.

${ }^{11}$ Manchas são os elementos da paisagem que se diferenciam dos elementos circundantes (Forman 1995). Em uma área urbanizada, manchas

são compostas por elementos naturais, como vegetação, por exemplo. 
De acordo com Bennet (2003), os corredores de habitat são considerados como meios mais eficazes de promover a conectividade na paisagem quando:

- Boa parte da paisagem está modificada e é inabitável para as espécies nativas;

- Os indivíduos são especialistas ou possuem uma estrita dependência de habitats que não sofreram transformações e distúrbios;

- As espécies possuem uma limitação na dimensão de seus movimentos em relação à distância a ser percorrida. Nestas situações, o corredor precisa fornecer recursos para manter os indivíduos e populações que nele residem;

- O objetivo é manter a continuidade de populações entre os habitats ao invés de simplesmente fomentar o movimento esporádico de indivíduos;

- O objetivo é a continuidade da existência de comunidades inteiras de fauna;

- A manutenção de processos ecossistêmicos necessita de habitats contínuos.

Em escala local, existem muitos exemplos diários de corredores de habitats que conectam fragmentos de vegetação natural em paisagens ocupadas com usos humanos. Podem atuar como conexões os elementos lineares, como as cercas vivas de árvores que dividem propriedades rurais, plantações, remanescentes de vegetação lindeiros a rodovias, matas ciliares, fragmentos de florestas que não são para corte. Da mesma forma para outras escalas, em que amplas faixas de vegetação que conectam florestas podem funcionar como conexões, em escalas de paisagem, regionais e até mesmo continentais.

Os corredores de habitats podem ser distinguidos a partir de suas diferentes origens e formações (FORMAN; GODRON, 1986). Podem ser de origem natural, como os rios e sua vegetação ciliar, que fazem parte de uma situação topográfica e ambiental específica, resultante de processos naturais. Podem ser remanescentes de matas e florestas mantidas em meio a áreas com usos distintos e com o ambiente alterado para servirem como ligações de conectividade. E ainda provenientes de uma regeneração natural que ocorre pelo resultado do repovoamento natural de espécies vegetais compondo um trecho de vegetação que anteriormente se encontrava desmatado. Em geral, este processo natural é resultado da ação de ventos e de animais dispersores de sementes.

Os corredores podem também ser plantados pelos homens, como as próprias culturas rurais, as barreiras de ventos criadas para proteção de propriedades e cinturões verdes urbanos, os quais também permitem a mobilidade de espécies pela paisagem. Existem, por fim, os corredores de habitats alterados, como áreas sob a rede elétrica de alta tensão e às margens de rodovias. 
QUADRO 2: Síntese do potencial de eficiência/efetividade de diferentes tipos de ligações entre paisagens que apresentam diferentes níveis de alterações (distúrbios) ambientais (adaptado de BENNET, 2003).

TIPO DE LIGAÇÃO

\begin{tabular}{|c|c|c|c|}
\hline & MOSAICO DE HABITATS & \multicolumn{2}{|c|}{ HABITATS ESPECÍFICOS } \\
\hline & & $\begin{array}{l}\text { TRAMPOLINS } \\
\text { ECOLÓGICOS }\end{array}$ & $\begin{array}{c}\text { CORREDORES } \\
\text { DE HABITATS }\end{array}$ \\
\hline \multicolumn{4}{|c|}{ PAISAGENS COM POUCAS ALTERAC̣ÕES } \\
\hline Espécies tolerantes às alterações nos habitats & $\star \star \star$ & $\star \star \star$ & - \\
\hline Espécies intolerantes às alterações nos habitats & $\star$ & $\star$ & $\star \star \star$ \\
\hline Espécies de grande mobilidade e área de vida & $\star \star \star$ & $\star \star \star$ & $\star$ \\
\hline Comunidades e processos ecológicos & $\star \star \star$ & $\star$ & $\star \star \star$ \\
\hline
\end{tabular}

PAISAGENS COM GRANDES ALTERAÇÕES

\begin{tabular}{l|c|c|c}
\hline Espécies tolerantes às alterações nos habitats & $\star$ & $\star$ & $\star \star \star$ \\
\hline Espécies intolerantes às alterações nos habitats & - & $\star$ & $\star \star \star$ \\
\hline Espécies de grande mobilidade e área de vida & $\star$ & - & $\star$ \\
\hline Comunidades e processos ecológicos & - & $\star \star \star$ & \\
\hline
\end{tabular}

LEGENDA: $\star \star \star$ abordagem eficaz; $\star$ abordagem pouco eficaz; - improvável de ser uma abordagem eficaz. 


\subsubsection{TRAMPOLINS ECOLÓGICOS}

Os trampolins ecológicos são formados por habitats de tamanhos variados e reduzidos, mas capazes de viabilizar pequenos movimentos sobre ambientes hostis para espécies que não conseguem se movimentar diretamente. Assim, a conectividade entre indivíduos e populações é alcançada por meio de movimentos curtos e de paradas, realizados de trampolim a trampolim por todo o eixo de ligação.

Em matrizes urbanas, pequenas áreas com vegetação podem ser consideradas como pontos de natureza entremeados em matrizes urbanas, como menciona Forman (1995). São elementos muito importantes porque promovem contato e adaptação das espécies à matriz, e também diminuem a resistência da matriz aos fluxos ecológicos.

Os trampolins ecológicos são passíveis de estabelecer a conectividade na paisagem:

-Para as espécies que já se movem com frequência na paisagem entre fragmentos de recursos naturais, seja por variações sazonais de oferta de alimentos, isolamento entre os abrigos e de áreas de busca de alimento;

-Para as espécies que possuem mobilidade e são capazes de percorrer a distância existente entre os trampolins ecológicos;

-Para as espécies que são tolerantes às paisagens com alterações decorrentes de distúrbios, mas não necessariamente capazes de viver dentro dessas áreas;

- Onde o objetivo é o de manter a continuidade de processos ecológicos que dependem de movimentos de animais.

Como os corredores de habitats, os trampolins ecológicos têm diferentes composições. Podem ser manchas naturais, como uma cadeia de alagados por toda uma região, ou uma área de transição de manchas de florestas tropicais em meio a um campo de cerrado. Pequenos fragmentos de florestas podem também atuar como trampolins.

Os trampolins ecológicos de habitats podem também ser originados por ações humanas, como as florestas plantadas, lagos artificiais ou uma sequência de parques urbanos em meio a uma área metropolitana. 


\subsubsection{EXIGÊNCIAS ECOLÓGICAS DAS ESPÉCIES}

Uma questão essencial na discussão sobre a importância e a viabilidade dos corredores em uma paisagem é que, para que as espécies de animais e comunidades sejam bem sucedidas, a conectividade deve ser suficiente para os indivíduos se moverem em busca de recursos em todas as etapas de suas vidas.

Outro ponto importante é que não existe uma solução que atenderá as necessidades de todas as espécies; ou seja, uma conexão que serve positivamente para a qualidade de vida e sobrevivência de uma espécie pode não servir para outras, já que muitas vezes necessitam de uma escala e composição de conexão diferentes.

As abordagens de análise da paisagem pautadas na identificação de seus padrões e processos ajudam a identificar os elementos que precisam estar presentes e as relações entre as medidas e os padrões de paisagem (e.g. riqueza de espécies). Entretanto, são insuficientes para se definir a quantidade e distribuição adequadas desses elementos além da composição, configuração e quantidade das características das paisagens necessárias para manter sua biota (LAMBECK, 1997).

\section{ESPÉCIES GUARDA-CHUVA}

As exigências ecológicas das espécies são, portanto, de extrema importância para se definir as características da paisagem que garantirão a sua sobrevivência. Neste contexto, o desafio passa a ser encontrar meios eficientes de descobrir as necessidades das espécies, sem ter de estudar cada uma individualmente. Para resolver tal situação, há a proposta do uso de "espécies guarda-chuva" (NOSS, 1990).

Neste conceito, são empregadas espécies cujas exigências de subsistência deveriam englobar as de outras menos exigentes. Essas exigências podem ser de diferentes tipos: necessidade de grandes áreas de habitat, capacidade limitada de locomoção, necessidade de habitat muito específico, entre outras

Por causa de suas dietas, tamanhos e tolerâncias físicas a mudanças ambientais, os carnívoros geralmente funcionam como espécies "guarda-chuva", já que são importantes reguladores de populações de presas ou potenciais dispersores de sementes (REDFORD, 1992). Porém, além de muitas espécies de carnívoros terem uma grande capacidade de dispersão, parecem tolerar ou cruzar ambientes alterados com facilidade (METZGER, 2006). Assim, essas espécies não serviriam como "guarda-chuva", por exemplo, para aquelas com baixa capacidade de dispersão. 
Não obstante, como a maioria das espécies em um ecossistema tem necessidades muito distintas, é improvável que apenas uma sirva como um "guarda-chuva" eficiente (LAMBECK, 1997). Foi com essa preocupação que surgiu o uso de guildas ou grupos funcionais como indicadores.

No entanto, estas assembléias são artificiais e, por vezes, heterogêneas demais, e o fato de as espécies utilizarem determinados recursos da mesma maneira não significa que respondam igualmente às perturbações antrópicas (LINDENMAYER et al., 2002).

Por outro lado, Metzger (2006) afirma que se pode adotar uma abordagem de múltiplas espécies "guarda-chuva", de modo que se perceba a paisagem a partir do ponto de vista e da escala das espécies. Essa abordagem considera todo o mosaico, identificando os fragmentos e conexões mais importantes, tendo como objetivo selecionar um grupo de espécies altamente exigente, com demandas ecológicas distintas (e.g requerimento de área; capacidade de dispersão; especialização de micro-habitat). O estudo detalhado dessas espécies pode permitir a compreensão das condições necessárias para a sobrevivência das espécies analisadas e, a partir daí, identificar as áreas importantes que devem ser protegidas, além de dar subsídios para o aumento da conectividade funcional de paisagens a partir de informações sobre a capacidade de deslocamento de espécies e larguras mínimas de corredores florestais.

Assim, perceber a paisagem sob o ponto de vista das espécies e incluir resultados desses estudos ecológicos no processo de conformação de um sistema de corredores agregará mais uma qualidade ao sistema, dotando-o de capacidades de abrigar espécies de animais que muito podem contribuir para a dinâmica ecológica local e regional.

\subsection{A ESCALA DE INVESTIGACÃ̃}

A escala é um tópico essencial em planejamento da paisagem e fundamental para as conclusões alcançadas por pesquisadores e seus estudos e suas possíveis extrapolações para diferentes tempos e locais. Assim, a escolha da melhor escala de estudo é uma tarefa importante e delicada.

Para Turner, Gardner e O’Nell, (2001), o termo escala refere-se à dimensão espacial e temporal de um objeto ou processo. As escalas são caracterizadas pela granulação da imagem (resolução espacial) contida nos dados utilizados e pela extensão (tamanho da área de estudo). Não existe uma pré-determinação sobre a escala certa para se estudar um determinado processo. Assim, as 
análises "multiescalares" continuam sendo utilizadas, para que se possa selecioná-las a partir de questionamentos e objetivos presentes nas propostas.

Em um exemplo de abordagem de planejamento da paisagem multiescalar, referência conceitual e metodológica fundamental, Hellmund (1993, 2006) propõe um método para a elaboração de planos e projetos de corredores ecológicos composto por quatro etapas, sendo que cada uma delas corresponde a uma escala diferente no processo de conformação de um mesmo corredor.

Para exemplificar algumas experiências de projetos de corredores em diferentes escalas, alguns projetos são apresentados a seguir.

\subsubsection{CORREDOR SUBCONTINENTAL}

O Corredor Biológico Mesoamericano - The Mesoamerican Biological Corridor ${ }^{12}$ - é um corredor multinacional que liga a parte Sul do México e segue por meio de quase toda a América Central, conectando uma série de parques nacionais. É composto por oito países: Belize, Costa Rica, El Salvador, Guatemala, Honduras, México, Nicarágua e Panamá, os quais se comprometeram, mediante a Comissão Centro Americana de Meio Ambiente e Desenvolvimento, a manter e proteger a paisagem, o meio ambiente, e conservá-los.

O corredor cobre uma área de aproximadamente $768.990 \mathrm{~km}^{2}$ hectares e foi criado em 1998 com a proposta de proteger 106 espécies de animais ameaçadas de extinção. Trata-se do desdobramento de um projeto anterior, intitulado "Passo da Pantera" (Panter Patch), proposto no início dos anos 1990.

FIGURA 2 - Corredor

Mesoamericano. Informações obtidas em

http://www-radar.jpl.nasa.gov/

centralamericamap/ca/index.htm, acessado em 21/10/2011
${ }^{12}$ Informações sobre o corredor obtidas em http://www.pnuma_org/recnat_ing/ Ing/cbmpres.php. Acessso em 12/09/2011.

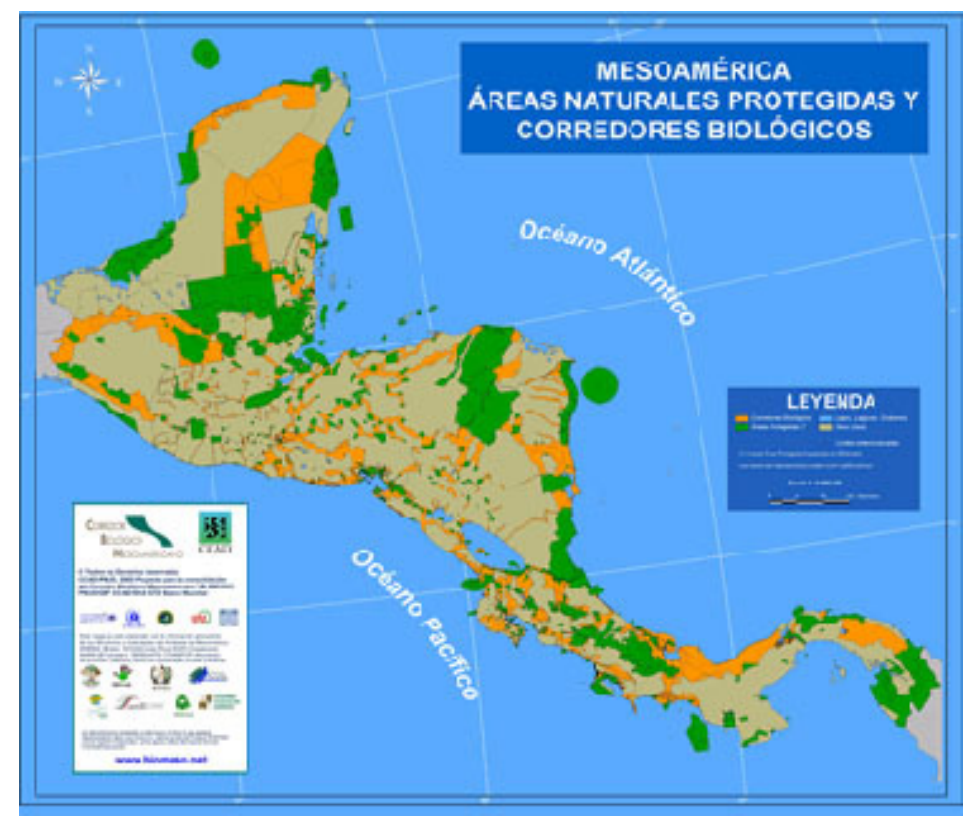




\subsubsection{CORREDOR REGIONAL}

Como exemplo de corredor para uma escala regional, temos o que liga a Estação Biológica La Selva (La Selva Biologica Station) ao Parque Nacional Braulio Carrillo (The Braulio Carrillo National Park), localizado na Costa Rica (BENNET, 2003). Trata-se de um representante de reserva de Floresta Primária preservada que recobre toda a encosta do Caribe e da América Central.

O corredor possui uma largura que varia de 3 a 6 quilômetros e um comprimento de 18 quilômetros, contando com uma área média de 9000 hectares. Foi criado em 1986 e teve sua área incorporada ao parque nacional. O projeto e a execução foram realizados com fundos de entidades e organizações americanas, sendo que o principal objetivo foi o de aumentar e preservar a biodiversidade da fauna e flora, em especial abrigar e proteger espécies de aves migratórias da região. Uma imagem da dimensão e localização do corredor pode ser vista na figura 3 ao lado.

\subsubsection{CORREDOR LOCAL}

O Corredor Australiano, criado em Queensland, exemplifica a escala mais típica de um projeto de corredor. Com 1,2 km, conecta o setor leste de Lake Barrines do Parque Nacional Crater Lakes com a parte oeste de Gadgarra State Forest, uma floresta tropical. Centenas de espécies de árvores tropicais se estabeleceram na área, a partir de sementes locais, ao longo de quatro anos. O inicio da implantação ocorreu em 1992 e encontra-se hoje concluída. O projeto representa um processo de trabalho que integrou as áreas da agricultura, silvicultura e conservação da natureza e pode ser visualizado na figura ao lado.

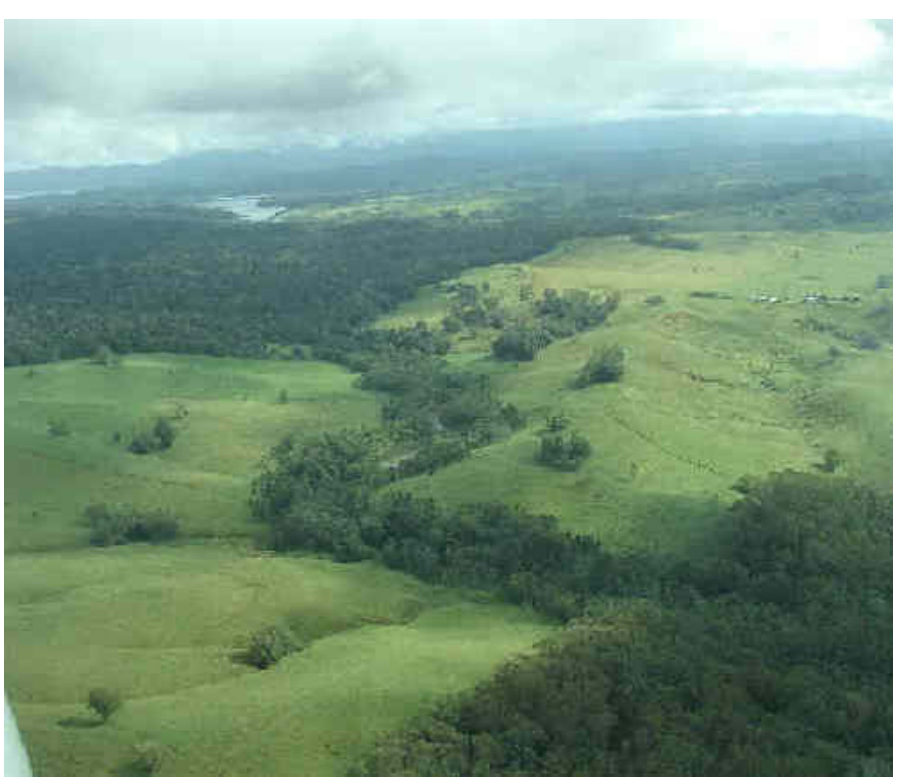

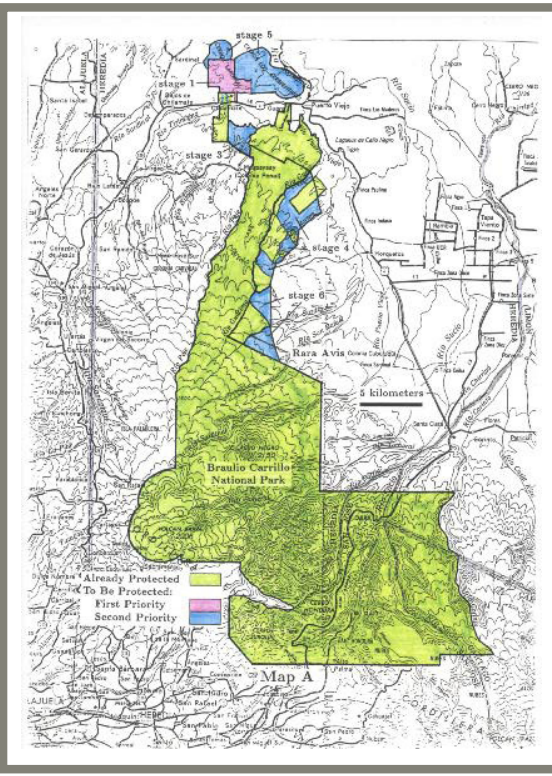

Figura 3: Corredor de ligação da Estação Biológica La Selva (La Selva Biologica Station). Informações obtidas em http://life.ou.edu/ pubs/reserves/node14.html, acessado em 25/10/2011.

\section{Foto 1 Corredor Queensland.}

Informações obtidas em http://www. treat.net.au/projects/Donaghycph_06. html acessado em 25/10/2011. 


\subsubsection{CORREDOR DE PEQUENA ESCALA}

O contato de rodovias com o sistema de corredores ecológicos age como barreira, causando interferências e impactos sobre os animais e a manutenção de trocas gênicas para vegetação. Uma solução para o problema é a construção de túneis de travessias ou de pontes vegetadas, que servem como condutores de fluxos.

Um exemplo interessante de projeto de ponte para travessia de animais, que age com medida mitigadora eficiente, foi construído sobre uma rodovia de fluxo intensivo de veículos, com alta incidência de atropelamentos e acidentes decorrentes de colisões com animais: a rodovia interestadual 70, em Washington, EUA ${ }^{13}$.

A travessia é composta por faixas com vegetação florestal, arbustivas e de pastos, além de ser amparada por uma proteção ao longo de toda a rodovia, que é cercada, direciona e conduz, com segurança para o outro lado, animais como ursos, veados, pumas, alces e linces.

O projeto apresentado ao lado, traz detalhes e soluções importantes para projetos de túneis e pontes de travessias para a fauna, como o uso de painéis pré-moldados de concreto encaixados e cobertos com vegetação. A ponte é suficientemente ampla para as faixas de florestas, arbustos e pastagens, com o objetivo de satisfazer as necessidades da maioria dos animais na área, e quilômetros de cercas em ambos os lados da rodovia servem de funil para a travessia dos animais sobre a ponte.

A importância dessas passagens é reconhecida, mas ainda existem muitas dúvidas e dificuldades em como fazê-las da melhor maneira possível.

Nesse caso específico, os pesquisadores envolvidos com a equipe do projeto afirmam que a instalação de uma ponte dessa natureza é capaz de beneficiar espécies ameaçada de extinção, como o felino lince-canadense (Lynx canadensis). A maior preocupaçao é permitir a ligação entre as espécies que vivem afastadas pela rodovia, já que a fragmentação de habitats faz com se tornem,

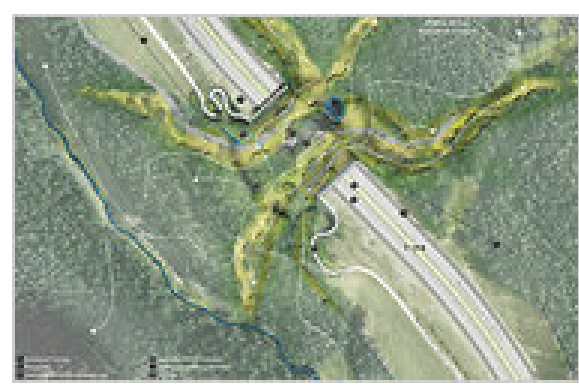

FIGURA 4 - Ponte para travessia de animais. Autor: Michael Van Valkenburgh \& Associates, New York, 2011. Informações obtidas em http:// www.nytimes.com/2011/01/24/science/ earth/24overpass.html?_r=1. Acessado em $21 / 12 / 2011$

${ }^{13}$ Informações obtidas em http://www. nytimes.com/2011/01/24/science/

earth/24overpass.html?_r=1 acessado em 02/02/2011. 
ao longo do tempo, geneticamente isoladas.

\subsubsection{CORREDORES VERDES URBANOS (GREENWAYS)}

Os corredores verdes ou greenways, do inglês, têm função ecológica definida pelos conceitos de ecologia da paisagem já apresentados. Contudo, é necessário estabelecer outras relações a esses elementos lineares, ampliando a sua importância socioeconômica e tornando-os mais compatíveis com os usos urbanos (FRISCHENBRUDER ; PELLEGRINO, 2006).

As redes de corredores verdes são também conhecidas como infraestrutura verde que corresponde a uma rede interconectada de espaços verdes que conservam as funções e valores naturais dos ecossistemas e fornecem uma série de beneficios às populações humanas (HELLMUND, 1993; 2006).

De modo geral, os corredores verdes urbanos são elementos lineares que servem como conexão entre um fragmento verde e outro e que integram equipamentos e outras funções importantes para a cidade.

Entre as funções básicas dos corredores verdes urbanos estão:

-Manutenção da biodiversidade: tem como objetivo permitir a movimentação das espécies animais e vegetais, garantindo assim sua continuidade. Em São Paulo e em outras áreas urbanas, os corredores podem ampliar a movimentação e a disseminação de animais (aves e pequenos animais) e vegetais (principalmente sementes);

-Proteção aos cursos d'água: tem como objetivo preservar a qualidade da água e recuperar as áreas com interesse para drenagem, principalmente as várzeas e fundos de vale;

- Criação e incremento de espaços para recreação e cultura: têm a função de abrigar áreas de lazer e priorizar o uso de transportes alternativos não poluentes. Podem incorporar elementos culturais importantes para a população, conectando-os e permitindo um percurso cultural e recreativo pela cidade.

\section{4 - ESTRUTURA ECOLÓGICA DA PAISAGEM}

A Estrutura Ecológica, representativa da paisagem natural ou primitiva, constitui um instrumento de sustentabilidade ecológica capaz de auxiliar no planejamento e na gestão da paisagem e de promover a leitura e definição das áreas que agregam valores ecológicos. A necessidade da sua implementação no planejamento e em projetos urbanos e regionais é reconhecida em várias iniciativas européias, como o Livro Verde do Ambiente Urbano (Comissão Européia), e Cidades Europeias Sustentáveis, mas também na Agenda XXI - local, criada na Conferência da Terra, em 
1992 (TELLES, 1997).

A metodologia proposta por Magalhães (2007), que parte do princípio de que a paisagem é uma realidade inacabada, um sistema aberto que não conhece fronteiras derivadas de dualismos racionalistas, como cidade/campo, natureza/cultura, paisagem/arquitetura, avança bastante e contribui com o presente estudo, especialmente pelo destaque e pela articulação dos elementos naturais.

A estrutura ecológica é considerada dinâmica, como um sistema que funciona pela interação de subsistemas: o Úmido, o Seco e o Cultural. Trata-se de um modelo de planejamento da paisagem baseado na continuidade (conectividade), reconhecendo a importância da estrutura fundamental da paisagem, que é composta pelo sistema úmido (linhas d'água e suas áreas relativamente planas adjacentes), sistema seco (encostas, divisores de bacias e topos de morros) e pelos habitats, sendo que o sistema seco é o que apresenta potencial para ser ocupado por áreas urbanas.

$\mathrm{Na}$ legislação portuguesa, a Estrutura Ecológica teve vários precursores, como o Domínio Hídrico, a Reserva Ecológica Nacional e a Reserva Agrícola Nacional. No entanto, a criação de uma figura de planejamento única e integrada, englobando, para além dos aspectos contemplados na legislação anterior, a Directiva Habitat, que diz respeito especificamente aos aspectos bióticos da Paisagem, só foi integrada na legislação portuguesa, no Decreto-Lei n 380/99, por meio da Estrutura Ecológica. Por força desse diploma, esta Estrutura tem de ser delimitada em todas as escalas de planejamento.

\subsubsection{PLANOS ECOLÓGICOS EM ÁREAS URBANAS}

\section{LISBOA/PORTUGAL}

Atualmente, vem sendo aplicada a política pública conhecida como a "Estrutura Ecológica Fundamental (EEF)", um desdobramento do Plano Verde de Lisboa (TELLES, 1997). Trata-se de um componente do Plano Diretor Municipal da cidade de Lisboa, publicado em 1993 ${ }^{14}$. Foi primeiramente mencionado no Master Plan de Lisboa (1994), em que foi proposta a manutenção de um anel verde periférico da cidade, composto pela colina e floresta da Monsanto, de um anel intermédio, formado pela colina do Castelo de São Jorge, de algumas radiais verdes, originadas pelo sistema de fundos de vales do município, e também de alguns elementos pontuais.

${ }^{14}$ Corresponde a um estudo e proposta sobre as áreas verdes de Lisboa que teve a coordenação do Arquiteto Paisagista Gonçalo Ribeiro Telles. Foi publicado em formato de um livro em 1997. Corresponde a uma referência do tema em Portugal e a partir dessa publicação outros livros foram lançados, de arquitetos e pesquisadores que se dedicaram a dar continuidade às investigações sobre o tema tratado. 
Alguns itens destacados do plano correspondem à estrutura verde, à estrutura ecológica, aos sistemas de vistas, às quintas (sítio e chácaras), aos elementos e às estruturas do espaço rural e à estrutura verde periurbana.

No referido estudo ganha destaque o conceito de que presença da natureza, por meio dos espaços abertos, espaços verdes e superfícies de água, é indispensável à qualidade do ambiente urbano, à beleza da cidade, ao lazer, à saúde e ao bem-estar da população. A vegetação tem importância na defesa do solo da erosão hídrica e eólica, permitindo a infiltração da água das chuvas e, por consequência, a diminuição da velocidade de escoamento superficial, devendo, por isso, revestir as cabeceiras de linhas d'águas, as áreas de maior infiltração e os leitos das cheias. E também como um elemento considerável para o conforto ambiental e termorregulação das áreas urbanas, e ainda como possibilidade da realização de longos percursos, a pé ou de bicicleta, em contato com a natureza e permitindo a contemplação da paisagem.

Segundo Telles, 1997:72

Os espaços verdes da cidade, quer verdes, quer pavimentados, não devem apenas se restringir às áreas residuais deixadas pelos edifícios, vias de circulação e parque de estacionamento, mas, pelo contrário, deverão constituir sistemas e estruturas com expressão territorial e cultural individualizada considerando as características tipológicas do conjunto urbano se integram. Devem assim ser recriados e concebidos como uma unidade indissociável do tecido edificado, complementando-se e reforçando-se mutuamente o seu significado e integrando o planejamento a todas as escalas.

O plano ilustrado na figura 7 a seguir demonstra a metodologia de referência que consegue definir os limites de setores da paisagem metropolitana de Lisboa por meio dos componentes da estrutura ecológica fundamental, como o sistema úmido, as áreas declivosas, áreas com florestas e vegetação significativas, áreas protegidas por legislação ambiental.

Os problemas das áreas metropolitanas não se reduzem, exclusivamente, aos do crescimento urbano, mas, ao contrário, abrangem aspectos de extrema complexidade que exigem a articulação e o relacionamento dos espaços urbano e rural. A estrutura verde periurbana apresenta características muito diferentes das da estrutura verde da cidade, não obedecendo, portanto, os mesmo pressupostos (TELLES, 1997). 


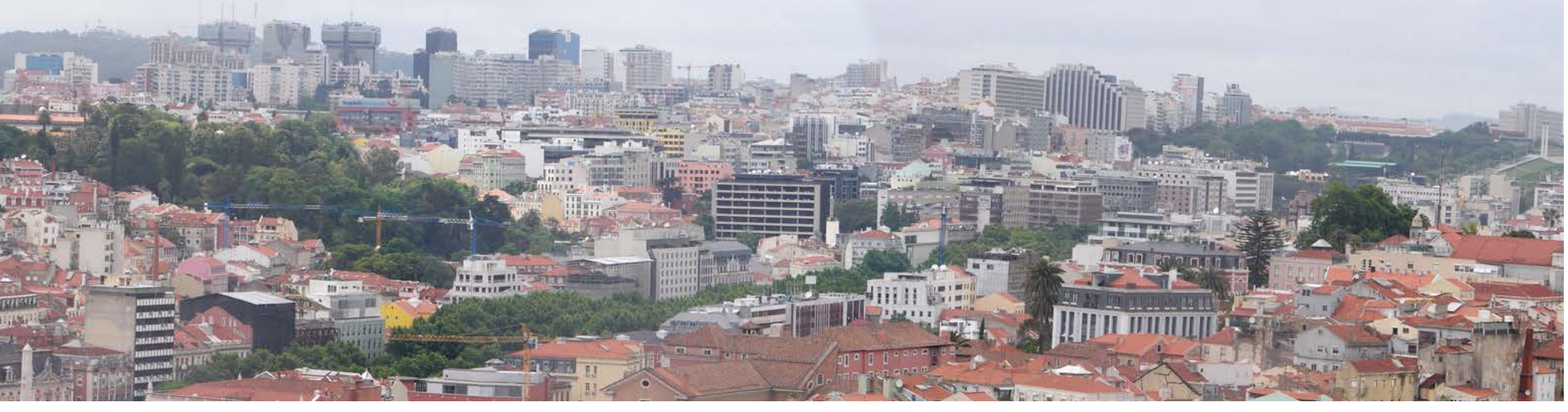

FOTO 2: acima. Imagem da parte central da cidade de Lisboa. É possível visualizar alguns elementos da estrutura ecológica: ao fundo, a colina com o Parque Monsanto, ao meio, um continuum naturale que se inicia na Avenida da Liberdade, passa pelo Parque Urbano Eduardo VII e pelo Corredor Verde da Monsanto, que, ao seu término faz a ligação com o Parque Monsanto para ciclistas e pedestres (Foto Julia Leite, 05/2010).

FIGURA 5: De fundamental importância ao plano é o Continuum Naturale, um sistema contínuo (corredor) de elementos naturais que permitem o funcionamento e desenvolvimento dos ecossistemas e a permanência do potencial genético (biodiversidade. MAGALHÃES, 2007

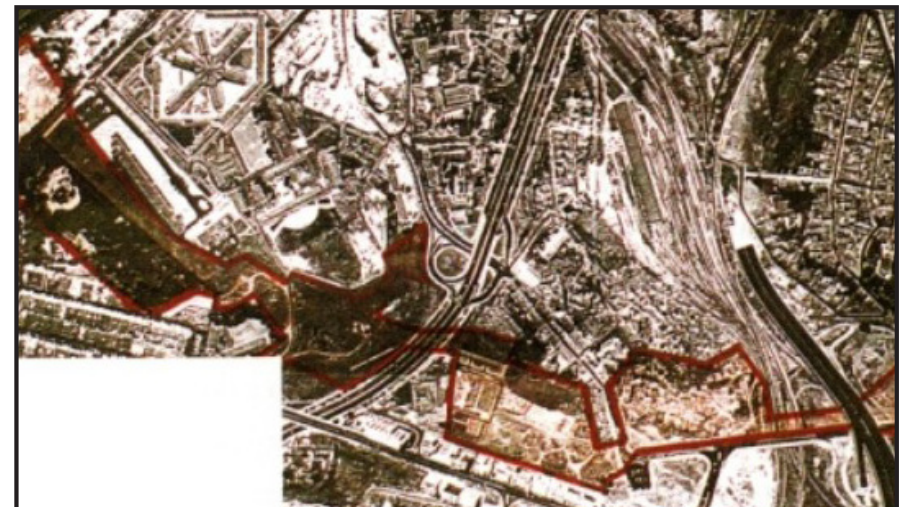




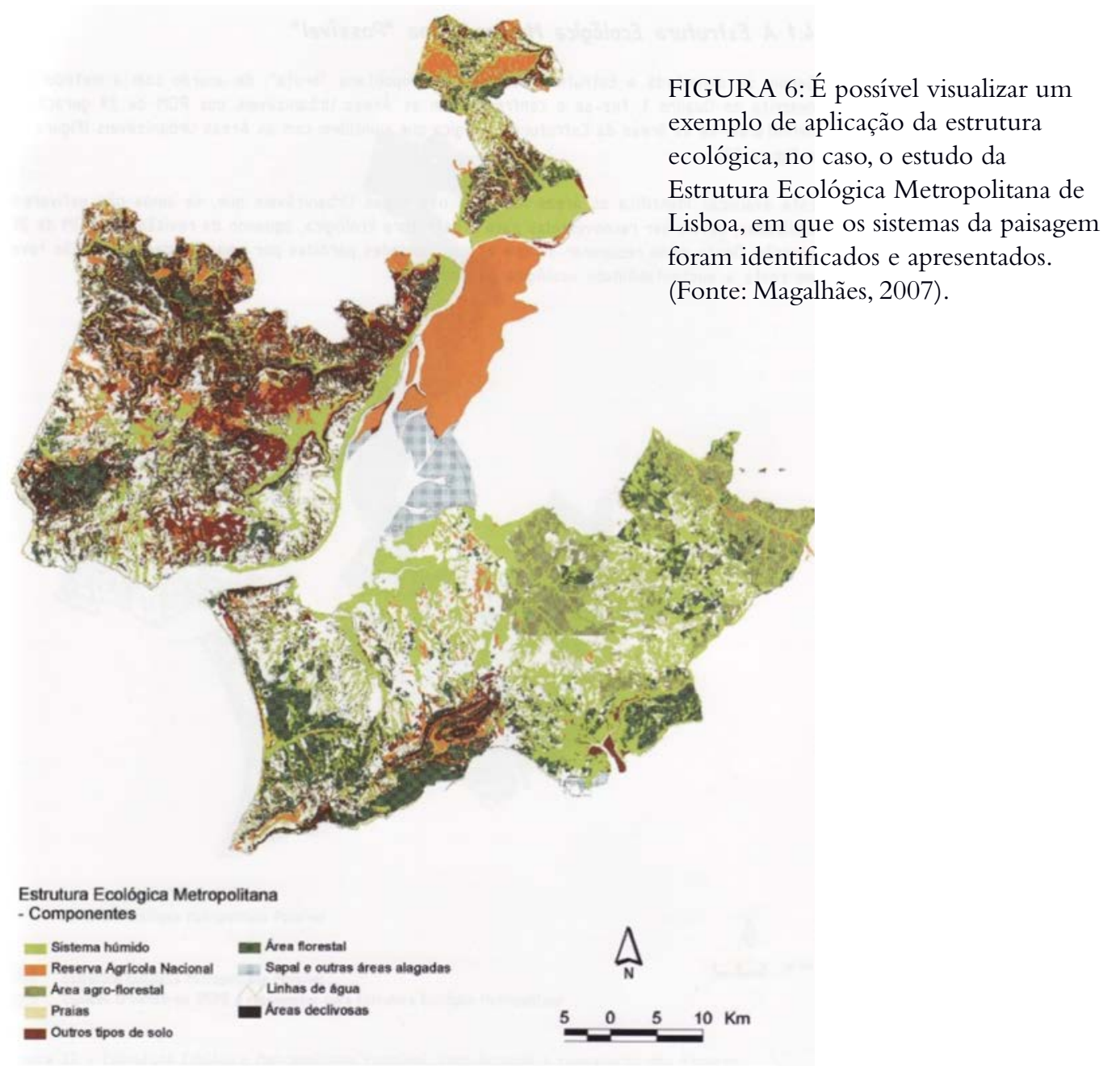

FIGURA 6: É possível visualizar um o de aplicação da estrutura

caso, o estudo d

foram identificados e apresentados.

(Fonte: Magalhães, 2007)

No Plano Verde de Lisboa, por meio da proposição de uma estrutura verde peri-urbana, pretende-se criar, basicamente, radiais verdes que alternem com os eixos de crescimento edificado, ligando-as à estrutura verde principal de Lisboa. Os objetivos são: salvaguardar áreas indispensáveis à manutenção do equilíbrio ecológico da região; impedir o alastramento do contínuo edificado; integrar no tecido urbano uma rede de ativação biológica que permita recriar o contato da população com os fenômenos naturais; melhorar e sanear o ambiente urbano; enquadrar as infraestruturas de transportes; fornecer à população suburbana suporte para as atividades de lazer e recreio e, finalmente, melhorar a qualidade estética do espaço, só possível através do contraste existente entre 


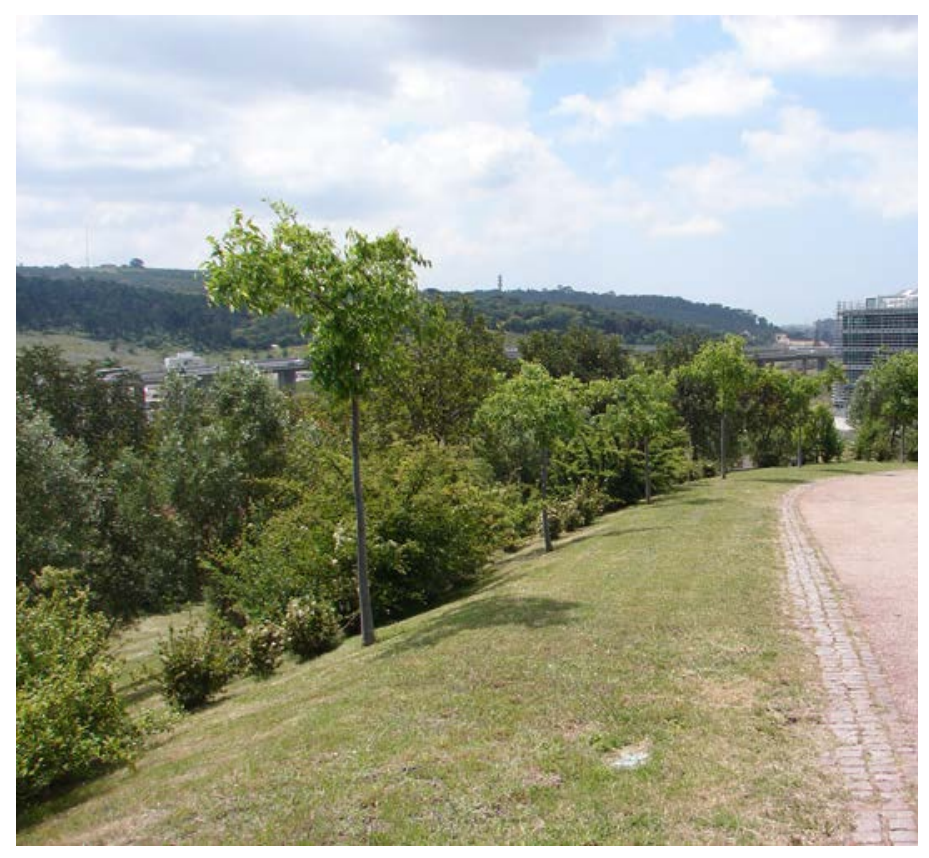

FOTO 3-Parque linear em Lisboa com ciclovia e passeio e pedestre que constitui um corredor de ligação entre o parque Eduardo VII e o Parque Monsanto. Trecho arborizado do corredor verde; no fundo, é possível observar o Parque Monsanto. (Fonte: Julia R. Leite, maio/2010).

os materiais vegetal e inerte, integrados na sua concepção, através da composição.

\section{BARCELONA/ESPANHA}

Como outra referência, também recente, podemos citar a Região Metropolitana de Barcelona, que, em 2001, contratou o ecólogo Richard Forman para aplicar o método de análise do mosaico territorial na busca de um estabelecimento de princípios básicos e de possíveis modelos para uma reformulação territorial. Esse projeto abriu novas perspectivas conceituais para planejar o território por ter tido o objetivo explícito de manter e melhorar os sistemas naturais de uma importante região urbana tendo como base princípios de ecologia da paisagem e disciplinas correlatas (FORMAN, 2004)

No "Mosaico Territorial", o ecólogo norte-americano Forman (2004) coloca a importância de se definir, em primeiro lugar, os possíveis enfoques de um plano, ou seja, as decisões relacionadas ao que é possível fazer e às metas a serem atingidas.

O autor produziu, em seu estudo, três relatórios, divididos nos seguintes temas: "Princípios e Modelos Básicos"; "Soluções Espaciais Alternativas"; "Plano de Ação e Recomendações Específicas". Para tanto, contou com apoio de diversos profissionais de agências de planejamento regional e pesquisadores catalães, os quais forneceram informações e dados biológicos, fisicos, sociais

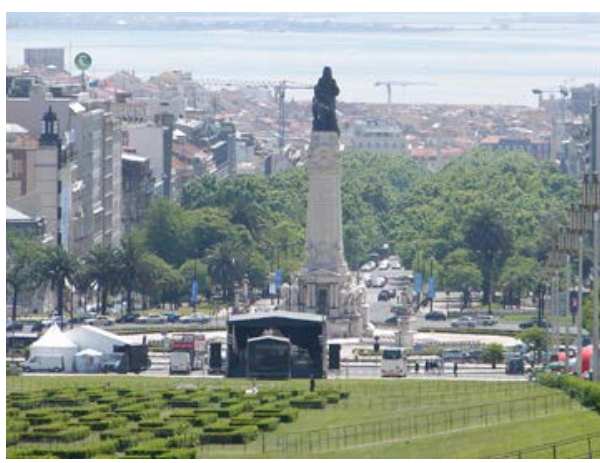

FOTO4-Estátua do Marquês de Pombal, Lisboa e a proximidade do parque com a arborização frondosa da Avenida da Liberdade, que configura um continuum naturale, proposto pelo Plano Verde. (Fonte: Julia R. Leite, maio/2010). 
necessários para o desenvolvimento do plano.

Segundo a equipe de ecólogos e planejadores urbanos catalães ${ }^{15}$, que também desenvolvem pesquisa e trabalhos paralelos na área do estudo, o plano de Forman (2004) é considerado como um trabalho superficial, já que não incluiu uma série de informações que já existiam ou que já estavam em discussão por diversos grupos e entidades locais. Entretanto, o plano foi classificado como pedagógico, pois permitiu que o tema fosse discutido, sendo que os planos subsequentes puderam aproveitar um pouco da metodologia desenvolvida. É possível também que haja desdobramentos dos estudos coordenados pelo norte-americano, como outro trabalho de planejamento urbano para a cidade, o "Plano Territorial Metropolitano de Barcelona", gerenciado pela equipe técnica da Generalitat de la Cataluna.
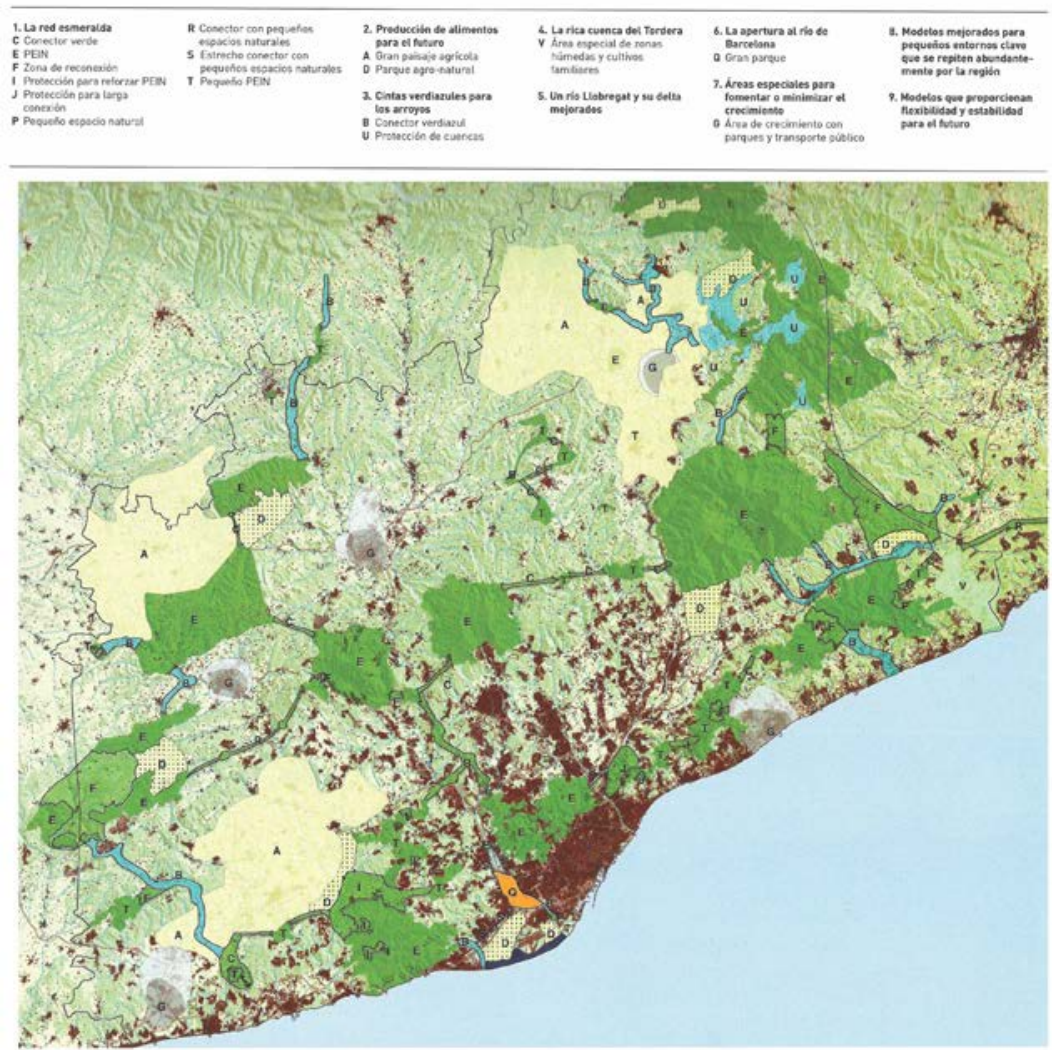

${ }^{15}$ Foram consultados, por meio de entrevistas, pesquisadores da Universidade Autônoma de Barcelona, mais especificamente, o CREAF - Centre de Recerca Ecologica i Aplications Forestals, em uma visita ao local, para se obter informações relacionadas ao Plano Mosaico Territorial de para a Região de Barcelona (03/2010)

FIGURA 7: Imagem do Plano Mosaico Territorial Barcelona.

Alternativa apresentada por Forman (2004), considerada, pelo autor, como mais promissora, em termos de conservação de ecossistemas. 


\section{ZURIQUE/SUÍÇA}

Podemos destacar ainda a cidade suíça de Zurique, que também possui uma abordagem ecológica no seu planejamento urbano da cidade.

Uma cidade "verde" à beira do lago é a proposta do Livro Verde de Zurique - The Green Book of Grun Stadt Zurique (GRUN STADT, 2006). Trata-se de um plano integrado de áreas verdes e espaços abertos e de educação ambiental que determina prioridades estratégicas para um desenvolvimento sustentável a longo prazo, como a melhoria de qualidade relacionada à oferta, para a população, de espaços abertos e verdes e à promoção e manutenção da biodiversidade local. Demonstra preocupação, especificamente, com os seguintes elementos: córrego e rios, vegetação viária, parques, praças, cemitérios e escolas.

Os espaços verdes propostos, além de corresponderem a uma grande extensão territorial, funcionam também como um anel verde envoltório da cidade.

Nos limites da cidade, os córregos, a grande oferta de espaços abertos, a presença de elementos verdes lineares (corredores) e as colinas e morros cobertos por florestas deverão compor um quadro significativo de espaços abertos conectados, referido como "impactante". Essa nova condição deverá garantir um novo visual para a imagem de Zurique, uma nova composição ainda mais verde. Há um apelo mercadológico do plano que realça a proposta como mantenedora "das qualidades verdes", característica que traria benefícios e investimentos para o município.

Especificamente, em cada distrito da cidade, seus espaços abertos e infraestruturas terão suas características locais reforçadas, como fileiras de árvores, córregos e jardins, aumentando a qualidade de vida das pessoas que ali moram, que poderão então desfrutar das qualidades projetais dos equipamentos e usos propostos. A experiência de aproximação com a água será valorizada em muitas situações, bem como a valorização de vistas, que deverão criar uma experiência urbana mais emocionante e com percursos e caminhos mais

Em sentido horário, Foto 5 e 6. Parque urbano Zürichhorn, em Zurique, Suiça. Beira lago, de multiplos usos: lazer, recreação e cultura. (Foto:

Julia R. Leite, Junho/2011). (Foto: Julia R. Leite, Junho/2011).
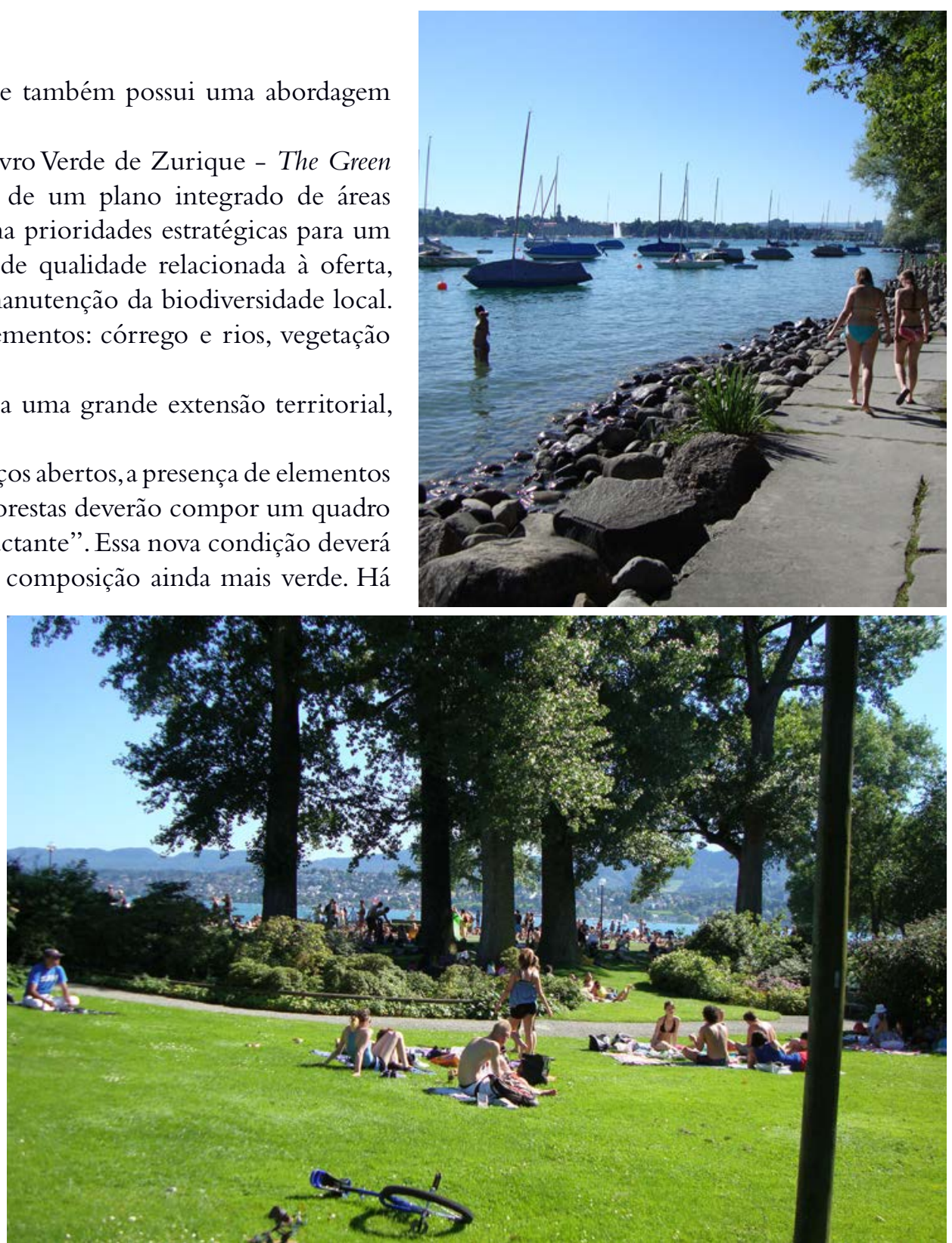


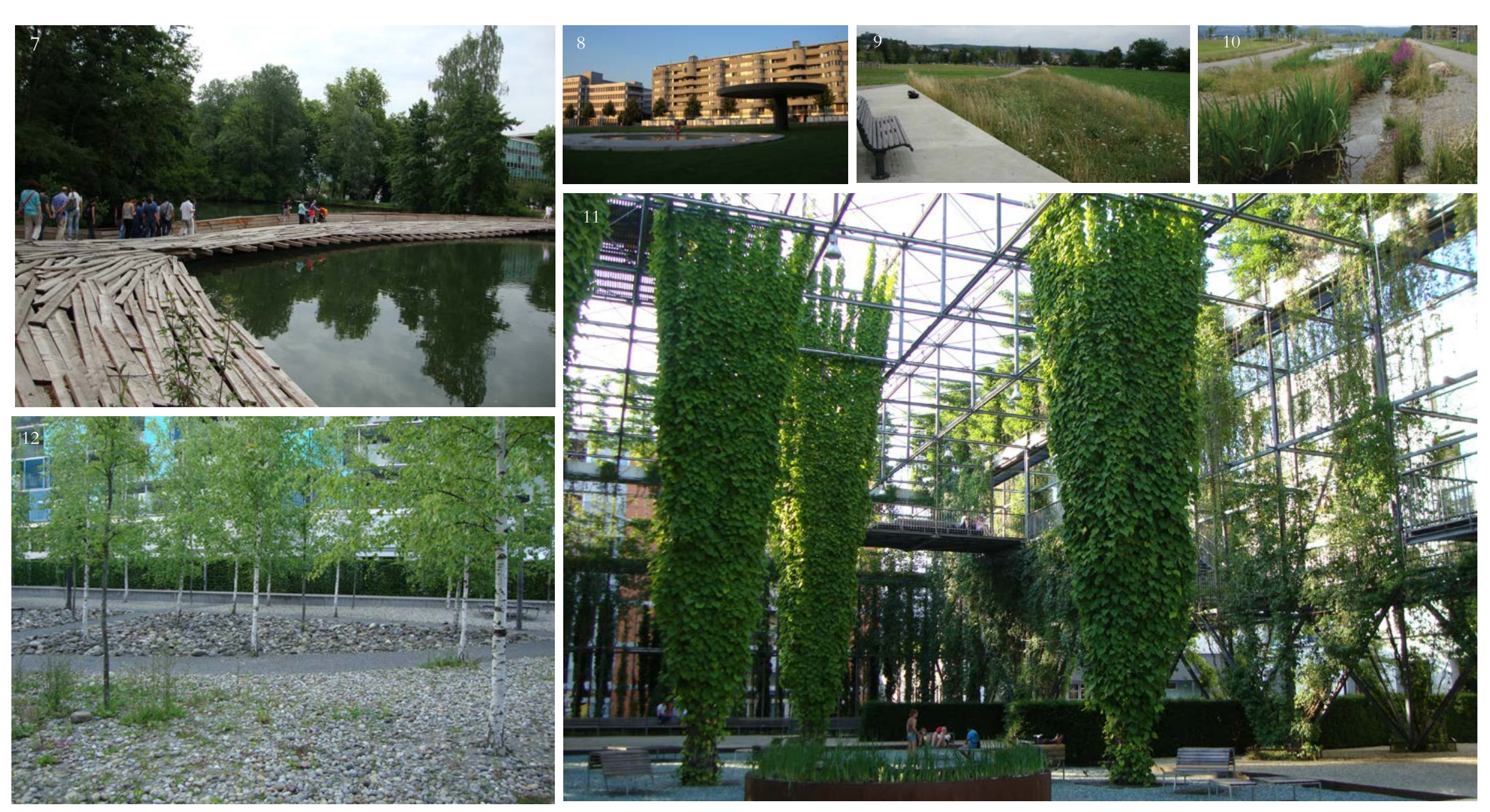

bem marcados.

Como ilustração de elementos do Livro Verde de Zurique, podemos citar alguns parques visitados. O bairro residencial Neu Oerlikon, antigo bairro industrial, fruto de uma revitalização recente, recebeu parques de uso local, como: MFO Park, Oerliker Park, Wahlenpark. São praças com projetos interessantes, contemporâneos, que possuem a vegetação como elemento de destaque.
FOTOS: 7-Passarela sobre lagoa de tratamento de água no FirmenPark

8-Parque de vizinhança, Wahlenpark 9-Campo de trigo no Griespark, 10-Alagado em Griespark, 11Vegetação suspensa na $M F O$ Park 12-Árvores em série no Oerlikerpark 
Outro parque que merece destaque é o Griespark, localizado em Volketswil, na região periurbana de Zurique. De característica ecológica, contém um córrego e sua área de várzea renaturalizados, bem como campos de trigos e outros alimentos evocando a paisagem rural num distrito periurbano.

Há também um empreendimento imobiliário que almeja a despoluição de um rio e revitalização do local, o Firmenpark Uster, na cidade de Uster, também na área periurbana de Zurique, numa fábrica desativada, cujo terreno e rio se encontram poluídos. A área vem sendo tratada, e é
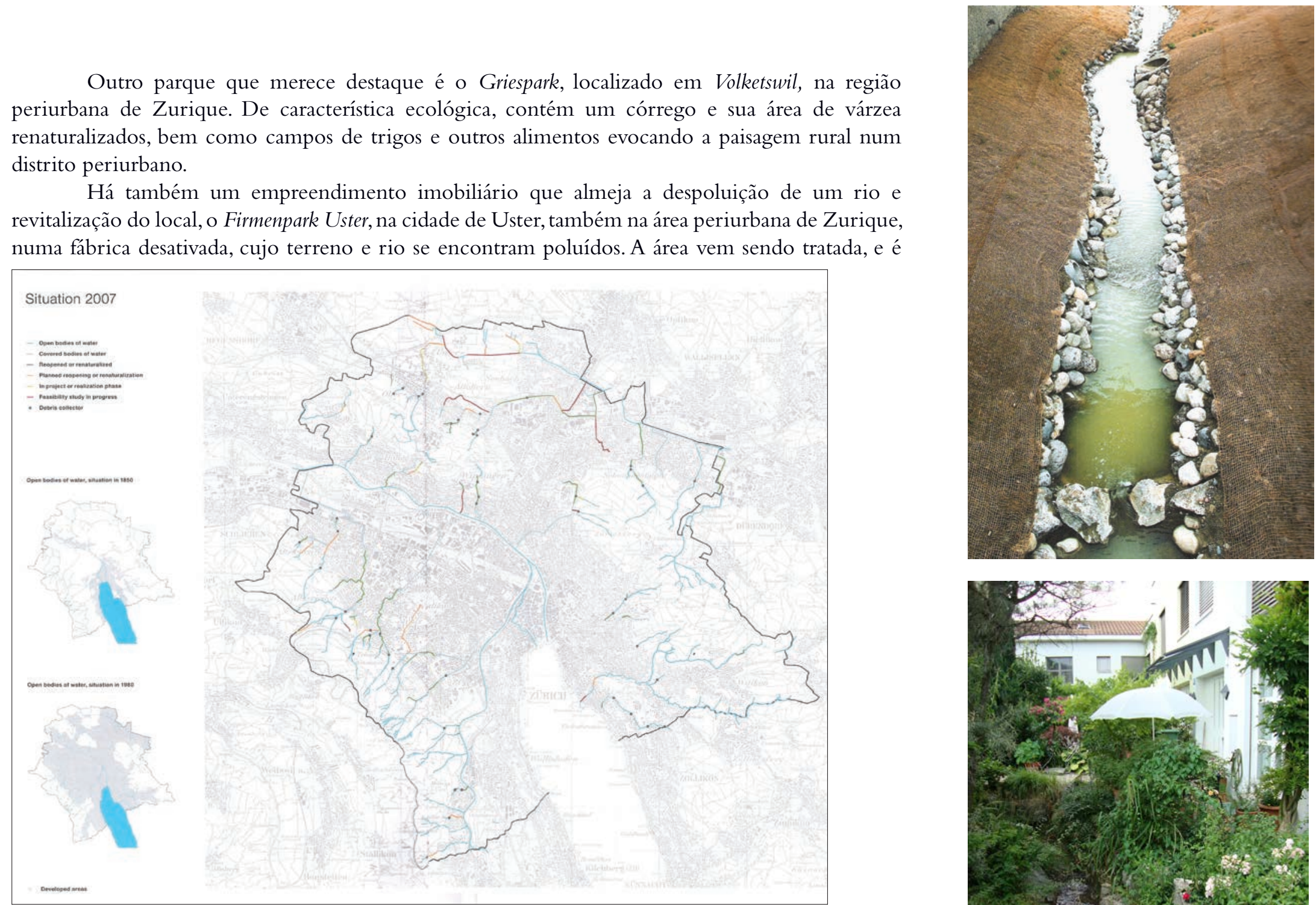

FIGURA 8: Situação dos rios e córregos na cidade de Zurique.

Projeto Stream (City of Zurique, 2007)

Ao lado, FOTOS 13 e 14, córregos renaturalizados, Zurique

(Foto Julia Leite, 2011)

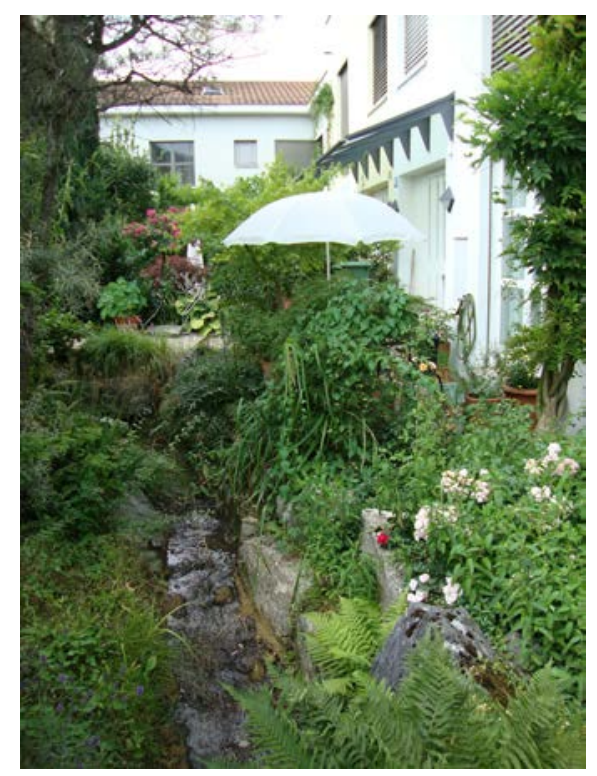


sede de uma interessante e arrojada praça, com obras de artistas e local de passeio.

Outro projeto realizado na cidade, que vai ao encontro das diretrizes do Livro Verde, é o Streams, em que foram realizados, até 2007,50 projetos de renaturalização de rios e córregos e reabertura de canais em aproximadamente $16 \mathrm{~km}$ de córregos. O projeto segue o conceito de separar as águas servidas do sistema de tratamento de esgotos, buscando criar alternativas para que as águas de córregos não sejam direcionadas para esse sistema. A renaturalização e reabertura dos canais não são apenas para embelezar ou criar novas áreas de lazer; são propostas, de fato, incorporadas ao processo de tratamento das águas da cidade.

\section{GENEVE/SUÍÇA}

Outro projeto que pode ser citado, desenvolvido como um trabalho de pesquisa ${ }^{16}$, Boudarie as a Project, para uma área periurbana de Geneve, Suíça, corresponde a um Park System PACA, Plaine de Aire. Trata-se de um Cinturão Verde para Geneve, composto por uma infraestrutura verde e que contém parques interligados por corredores verdes. O projeto discute os conceitos já abordados, como a coexistência do ambiente natural com a urbanização; uma rede de espaços verdes conectada; a multifuncionalidade e sustentabilidade de um projeto desta escala. Ou seja, um cinturão com áreas rurais, de lazer, de conservação, com usos planejados e adaptados às condições da paisagem.

Com o objetivo de confirmar e testar o desenvolvimento de um plano ecológico para a área estudada, nos próximos capítulos são abordados conceitos e princípios aqui discutidos que foram incorporados no processo de desenvolvimento de um sistema de corredores verdes na Região Metropolitana de São Paulo.
${ }^{16}$ Nathalie Monge, da Hepia - Haute ecole du paysage d'ingénierie et d'architecture, groupe de recherche Projet de Paysage, Genève/CH. 2011 IFLA - International Federation of Landscape Architecture -Congress Anais). 


\section{ABORDAGEM REGIONAL E ÁREA DE ABRANGÊNCIA DO ESTUDO}


Neste capítulo, apresentamos alguns aspectos da área estudada, inserida na Região Metropolitana de São Paulo, que demonstram e esclarecem a potencialidade e a oportunidade de essa área se tornar objeto de um planejamento ecológico da paisagem.

Importante ressaltar que não se trata de uma área intocada; ao contrário, ela já foi transformada por ações humanas há centenas de anos. Existem, pois, fragmentos de vegetação, os quais correspondem a áreas seminaturais alteradas, que precisam ser geridos. Os trechos que apresentam potencial de conservação e/ou recuperação são considerados aqui como naturais, mesmo em locais onde estão presentes sinais de ocupação.

De fato, a noção do que é natural em uma paisagem deve ser expandida não apenas para as grandes florestas, mas também para pequenos trechos em que a natureza pode existir e se manter, trazendo consigo os importantes serviços ambientais para a vida humana, além da conservação e diversidade de espécies adaptadas aos ambientes periurbanos. Assim, pequenos parques, praças, canteiros de vias públicas, jardins, quintais e tetos verdes são aqui tratados ampliando-se a idéia de Marris (2010), segundo o qual, se tentarmos, podemos ver o que há de sublime em "nossos quintais".

Para que as atividades e os usos humanos sejam agregados à preservação da natureza, não cabe apenas a ideia preservacionista de que as áreas protegidas são a única maneira de mantermos a natureza viva. Como bem destaca Marris (2011), é importante incluir outras formas de se promover essa conciliação, difundindo a concepção de que a natureza também pode ser criada pelos homens, o que não seria, necessariamente, apenas "menos pior". A natureza recriada pode vir a ser, inclusive, muito melhor do que a primária, além de muito relevante, o que nos direciona, por exemplo, e como proposto nesta tese, para o desenho de parques e corredores ecológicos. 
Abordamos também neste capítulo as políticas públicas relacionadas à gestão de recursos naturais da região selecionada, bem como a descrição de seus principais elementos naturais, essencial para se detalhar um sistema de corredores verdes.

Após esse contexto regional, a partir de alguns critérios, a análise foi direcionada para um determinado limite territorial, denominado área de abrangência do estudo. A partir deste momento, passamos a avaliar e mapear a área em uma escala de 1: 140.000 e com mais detalhes acerca da paisagem, incluindo informações relacionadas às unidades administrativas e ao uso do solo. Acrescentamos ainda informações dos municípios envolvidos a respeito das áreas de conservação e proteção.

No final do capítulo, trazemos informações sobre o crescimento urbano ocorrido em detrimento da supressão da vegetação em quatro períodos: 1975, 1986, 1995 e 2010. Os dados estão contidos em mapas, gráficos e tabelas e fomentam discussões acerca da dinâmica temporal da paisagem. Tal análise permitiu a elaboração de um mapa com pontos marcados na área estudada, os quais apresentam as maiores supressões da vegetação no período avaliado. Outro mapa produzido ilustra os trechos em que há concentração do crescimento urbano.

\subsection{CONTEXTO REGIONAL DA ÁREA EM ESTUDO}

\subsubsection{LOCALIZACÃ̃O}

O trecho escolhido como objeto de análise da paisagem localiza-se a oeste da Região Metropolitana de São Paulo (RMSP), e inclui dezessete municípios, como pode ser visualizado no Mapa 1 a seguir. Faz parte, portanto, da maior área metropolitana brasileira, composta por 39 municípios distribuídos em $850.100 \mathrm{~km}^{2}$. A RMSP é também a quinta região metropolitana mais populosa do planeta, com aproximadamente 20 milhões de habitantes (UNESCO, 2010). O trecho contém características de uma área periurbana, já que se localiza na borda da região metropolitana densamente urbanizada, e guarda ainda áreas pouco povoadas, que, pela proximidade dos diversos atrativos, vão se tornando mais valiosas e procuradas, tornando-se alvo de frequente crescimento.

O mesmo trecho é também parte dos Corredores de Biodiversidade, definidos pelo Programa Biota/FAPESP, em 2007. Ou seja, possui uma estrutura ecológica considerada relevante 
para a passagem de fauna e abrigo de flora, constituindo-se como um elo de conexão entre dois importantes biomas da Região Sudeste, a Mata Atlântica e o Cerrado.

O Programa Biota/FAPESP, desenvolvido ao longo de dois anos em todo o Estado de São Paulo, por meio de levantamentos e participação de 160 pesquisadores, registrou 10.500 espécies e identificou, pela primeira vez, as áreas onde devem ser concentrados esforços para a recuperação florestal em solo paulista. A iniciativa foi realizada pela parceria do Instituto de Botânica com o Instituto Florestal de São Paulo (IF) e Fundação Florestal, vinculados à Secretaria Estadual de Meio Ambiente (SMA), e também com as universidades estaduais USP, Unicamp e UNESP, e as organizações não governamentais Conservação Internacional (CI-Brasil) e Centro de Referência e Informação Ambiental (CRIA) ${ }^{17}$.

Dentro desse programa, foi realizado o estudo "Diretrizes da Política de Conservação e Restauração da Biodiversidade no Estado de São Paulo”. Os dados produzidos indicam áreas para a criação de corredores no estado, auxiliam a estabelecer prioridades nas ações da Polícia Militar Ambiental e promovem a base científica para definir áreas prioritárias a serem beneficiadas com recursos destinados à compensação ambiental exigidos dos empreendedores ${ }^{18}$.

De acordo com os mapas-síntese do estudo acima descrito, no setor oeste da RMSP (aqui pesquisado), mais especificamente do centro para o sul, existem conexões com alto grau de prioridade (as quais correspondem, na legenda do mapa, aos valores 3 e 4, sendo que 1 corresponde à prioridade mais alta e 7 , à mais baixa), sendo, portanto, áreas que possuem grau de urgência na manutenção da conectividade em todo o estado. Ainda sobre os mapas do Programa Biota/ FAPESP, temos no sudoeste do setor oeste da RMSP uma classificação de alta importância para a conservação da biodiversidade do Estado de São Paulo.

Além disso, parte do trecho estudado se encontra na Área de Proteção aos Mananciais, limite criado pela Lei Estadual n. 9.866 de 1997, para garantir a integridade do Sistema Integrado de Abastecimento de Água, composto por seis sistemas produtores de água: Cantareira, Guarapiranga, Rio Grande (Billings), Cotia (Alto e Baixo), Alto Tietê, Rio Claro e Ribeirão da Estiva (de pequeno porte), os quais utilizam, basicamente, mananciais de superficie para o abastecimento metropolitano (MEYER, GROSTEIN e BIDERMAN, 2004).

A gestão dos recursos hídricos da RMSP é uma tarefa complexa que acarreta vários desafios, pois envolve uma área extensa, bastante urbanizada e industrializada. A gestão é feita pelo Sistema Integrado de Gerenciamento de Recursos Hídricos (SIGRH) e adota as bacias hidrográficas como Unidades de Gerenciamento de Recursos Hídricos, estabelecendo um sistema de gestão
${ }^{17}$ Informações obtidas no blog http: //inovabrasil.blogspot.com/2008/11/diretrizespara-conservao-e-restaurao.html, acessado em 05/11/2011.

${ }^{18}$ Informações obtidas no site do Programa Biota FAPESP http://www.biota.org.br/info/ complementa/, acessado em 10/11/2011. 
descentralizado, baseado nos Comitês das Bacias ${ }^{19}$.

Devido ao grande tamanho das bacias hidrográficas, optou-se pela criação das Áreas de Proteção e Recuperação dos Mananciais (APRM), que são formadas por uma ou mais sub-bacias, com tamanhos reduzidos, para facilitar a gestão. Estão em fase de elaboração, para cada APRM, leis específicas e Planos de Desenvolvimento e Proteção Ambiental (PDPAs) ${ }^{20}$.

No que se refere ao contexto regional, a área estudada se encontra nos limites da Bacia Hidrográfica do Alto Tietê, e o seu órgão gestor responsável é o Comitê da Bacia Hidrográfica do Alto Tietê (CBH-AT) ${ }^{21}$. O comitê é um órgão colegiado, de caráter consultivo e deliberativo, que compõe o SIGRH, com atuação nessa bacia ${ }^{22}$.

\subsubsection{RESERVA DA BIOSFERA DO CINTURÃO VERDE DE SÃO PAULO (RBCV)}

Outro instrumento de gestão e planejamento que incide no trecho aqui selecionado é o da Reserva da Biosfera do Cinturão Verde de São Paulo (RBCV). Trata-se de um importante anel verde protegido, que contém áreas naturais responsáveis pela qualidade de vida da metrópole, por meio de uma série de serviços ambientais prestados. Podemos citar os oferecidos por recursos hídricos e florestais, além de gêneros agrícolas, controle de desastres naturais, bem como aspectos culturais, dentre outros ${ }^{23}$.

As Reservas da Biosfera (RBs) foram criadas pelo Programa "O Homem e a Biosfera" MAB, da Organização das Nações Unidas para a Educação, a Ciência e a Cultura - UNESCO. Fundamentam-se no conceito da "organização", que significa direcionar programas para a conciliação entre conservação de recursos naturais e desenvolvimento humano, e enfatizam a cogestão, ou seja, dispõem-se a negociar interessas e conflitos dos diferentes atores envolvidos com as questões apresentadas.

$\mathrm{O}$ conceito de RB define que essas reservas constituem locais destinados a explorar e demonstrar enfoques da conservação e do desenvolvimento sustentável, numa abordagem de escala regional. O objetivo é fomentar projetos relacionados ao desempenho de funções de conservação (paisagens, ecossistemas, espécies e diversidade genética), de desenvolvimento (econômico e humano, sustentáveis em seus três pilares principais - social, cultural e ecológico), de apoio
${ }^{19}$ Informações obtidas no site do SIRH: http://www.sigrh.sp.gov.br/cgi-bin/sigrh_home colegiado.exe?TEMA=APRESENTACAO\&CO $\mathrm{LEGIADO}=\mathrm{CRH} / \mathrm{CBH}-\mathrm{AT} \& \mathrm{lwgactw}=860613$ acessado em 18/11/2011

${ }^{21}$ Informações obtidas no site: http://www. fundacaofia.com.br/gdusm/apm.htm, acessado em $20 / 11 / 2011$

${ }^{21}$ Criado pela Lei Estadual no 7.663 de 30 de Dezembro de 1991, São Paulo-SP.

22 De acordo com o Estatuto do Comitê da Baci Hidrográfica do Alto Tietê (revisto e aprovado em 15/03/2005).

${ }^{23}$ Informações obtidas no site http://www. iflorestsp.br/rbcv/ocintverd.htm, acessado em 14/10/2009. 
logístico (a projetos educacionais, de investigação de aspectos locais, regionais, nacionais, que sejam vinculados à conservação e ao desenvolvimento sustentável) (RODRIGUES, 2006).

O envolvimento da população local é considerado como uma chave de êxito ou fracasso de qualquer reserva. Também as revisões periódicas das reservas devem ser fortalecidas buscando, ao mesmo tempo, seu envolvimento no marco de acordos multilaterais sobre o meio ambiente.

O tema de áreas urbanas passou a fazer parte das discussões do programa e foi definitivamente incluído pela definição de Reservas da Biosfera Urbanas - RBUs, sendo primeiramente mencionado no documento Application of the Biosphere Reserve Concept to Urban Areas and Their Hinterlands (UNESCO, 1998), o qual ensejava a criação do Man and Biosphere - $\mathrm{MAB}^{24}$. Posteriormente, em 2001, houve a constituição do Grupo Urbano do MAB, para a construção do referencial sobre criação e gestão de RBUs. Assim, o conceito de reserva da biosfera passou a ser aceito enquanto ferramenta apropriada à gestão urbana/periurbana integrada (RODRIGUES, 2006).

Podemos citar algumas cidades reconhecidas como RBUs: cidade do Cabo, Roma, Nova Iorque, Seul, Dar-es-Salaam (Tanzânia), Estocolmo e Kristianstad (Suécia), Chicago, Nova Orleans e São Paulo (UNESCO, 2004 apud RODRIGUES, 2006). Já no âmbito da Reserva da Biosfera da Mata Atlântica, as cidades de Recife e Florianópolis implementaram iniciativas-piloto de gestão nos moldes conceituais das RBUs (RODRIGUES, 2006).

As RBUs são reservas localizadas próximas a áreas urbanas importantes, dentro ou adjacentes aos seus limites, onde os ambientes natural, socioeconômico e cultural são moldados por fortes influências e pressões urbanas. Esse instrumento de gestão é estabelecido visando à mitigação dessas pressões e à melhoria da sustentabilidade urbana e regional (UNESCO, 2003a apud RODRIGUES, 2006).

A RBCV engloba integralmente a RMSP e a Baixada Santista e, de modo parcial, as Regiões Administrativas de Campinas, Registro, São José dos Campos e Sorocaba. Possui 23 milhões de habitantes (12\% da população brasileira ${ }^{25}$ ) em um total de 78 municípios (LINO et al., 2009).

Figura de proteção ambiental reconhecida internacionalmente pela UNESCO, a RBCV é parte integrante da Reserva da Biosfera da Mata Atlântica, sendo o objetivo principal de sua criação conservar e restaurar os corredores ecológicos que contêm uma diversidade biológica. O Cinturão Verde da Cidade de São Paulo foi declarado Reserva da Biosfera em 1993, ocasião em que havia outra iniciativa da mesma natureza em desenvolvimento, mas que era pensada para uma área muito maior: o litoral brasileiro, reconhecido como bioma da Mata Atlântica. Pela existência de
${ }^{24}$ Programa "O Homem e a Biosfera" - MAB, da Organização das Nações Unidas para a Educação, a Ciência e a Cultura - UNESCO.

${ }^{25}$ De acordo com o IBGE (2007), a população brasileira tem 183.987.291 habitantes. Informaç̃̃o obtida em http://www.ibge.gov.br/home/ estatistica/populacao/contagem2007/contagem. pdf, acessado em 24/11/2011. 
sobreposição de áreas, o Comitê Brasileiro MAB - UNESCO e o MAB Secretaria propuseram um arranjo institucional capaz de acomodar esses dois movimentos legítimos e inovadores, procurando manter ambas as identidades.

Foi assim que se definiu que a RBCV seria integrada à Reserva da Biosfera da Mata Atlântica, mas com ambas mantendo sistemas de gestão autônomos. Em 2008, foi iniciado um projeto de Revisão do Zoneamento da Reserva da Biosfera do Cinturão Verde, para o qual, mesmo em consonância com a Reserva da Mata Atlântica, foi utilizado um material complementar, com métodos e critérios para satisfazer as necessidades e desafios de sua gestão.

A revisão do zoneamento da RBCV (2009) foi fundamentada em quatro pontos principais (LINO et al., 2009):

1 - Algumas áreas protegidas, como os parques estaduais e/ou parques naturais municipais das cidades, foram imediatamente classificadas como "zonas núcleo"; outras, como Áreas de Proteção Ambiental (APAs), por meio de intervenções jurídicas, foram consideradas "zonas tampão" (amortecimento). A maior parte das áreas mantidas na revisão do zoneamento original ainda cabe na maioria dos conceitos adotados pelo atual zoneamento.

2- Durante um Congresso Mundial de Reservas da Biosfera que ocorreu em Madrid (2008), foram discutidos novos conceitos que deveriam ser desempenhados pelas RB, relacionados a temáticas contemporâneas, como: interação das reservas da biosfera com as alterações climáticas; de que forma suas zonas podem melhor responder aos desafios da urbanização e às necessidades de serviços ambientais prestados pelos ecossistemas. Um exemplo é o conceito de conectividade por meio da inclusão do papel de corredor ecológico às zonas de amortecimentos e de biodiversidade, podendo assim interligar e ajudar a proteger as zonas essenciais.

\section{FASEVI}

3- A utilização de alguns critérios do Guia Metodológico: Reserva da Mata Atlântica -

4- No ano de 2002, o grupo de trabalho MAB Urbano (UNESCO) foi criado para fornecer detalhes sobre os fundamentos e as vantagens da aplicação do conceito de reserva da biosfera em áreas urbanizadas. Foi constituída uma sólida estrutura conceitual para inspirar tanto as reservas já existentes como as que procuram o site para nomeação. A Reserva da Biosfera do Cinturão Verde é um exemplo tipicamente urbano/periurbano, sendo que a inclusão das áreas urbanas se dá pela compreensão e amadurecimento dos conceitos de biodiversidade e dos serviços ambientais ligados aos ecossistemas em paisagens urbanas. $O$ processo de revisão do zoneamento inclui critérios para 
adaptação e "entrada" em áreas densamente urbanizadas.

O grupo inicialmente decidiu classificar a área urbana da RBCV como de transição "especial", mas, devido a muitos questionamentos, para a inclusão oficial das áreas urbanas, foram definidos alguns critérios específicos, embora ainda inacabados.

Um aspecto muito importante da RBCV, que a coloca como uma instituição capaz de promover um sistema de corredores ecológicos para a área metropolitana, é que há o reconhecimento da importância de uma rede composta de áreas verdes, de modo que promovam os serviços ecológicos e ambientais. Essas áreas também constituem elos com fragmentos florestais funcionando como corredores ecológicos e de biodiversidade. A rede de áreas verdes da cidade de São Paulo e a de Santo André puderam ser classificadas como zonas tampão. Dados dos demais municípios não puderam ser agregados ao sistema pela ausência de bases de informações digitalizadas, mas se pretende incluí-los nas próximas etapas de revisão do zoneamento da reserva.

Pela intermunicipalidade que existe na $\mathrm{RBCV}$, o diálogo com as prefeituras e entre elas é extremamente necessário para o planejamento e a gestão da área. Em muitos casos, as RBs se apresentam como plataforma de discussão de questões relacionadas a formas de utilização do solo urbano e da terra, buscando esclarecer as mudanças que podem acarretar nas paisagens e ecossistemas locais. As classificações das RBs podem se constituir, aos municípios e seus respectivos planos diretores, como uma estratégia eficaz voltada à recuperação de áreas degradadas e reconstrução das paisagens naturais das cidades.

Outro instrumento legal também utilizado pela RBCV é a Lei de Proteção aos Mananciais, segundo a qual as áreas não urbanizadas e que pertencem à Área de Proteção aos Mananciais foram classificadas como zonas tampão.

\section{Zoneamento da RBCV}

De acordo com Lino et al. (2009), o zoneamento para as RBs é formado por três categorias para o planejamento da ocupação e uso do solo e de seus recursos ambientais. A RBCV segue o mesmo modelo:

ZONAS NÚCLEO: representam áreas significativas de ecossistemas específicos. No caso da RBCV, essas áreas são compostas, em sua maioria, por Unidades de Conservação Estaduais, mas estão incluídas na categoria Áreas de Proteção Integrais (Parques Federais, Estaduais, Municipais, 
Estações Ecológicas, Reservas Ecológicas, Reservas Biológicas, Monumentos Naturais, Refúgio de Vida Silvestre e Reservas Particulares de Proteção Natural - RPPNs). Já as zonas de vida silvestre estão dentro da categoria Áreas de Proteção Ambiental. O Parque Estadual da Cantareira e a Reserva Florestal do Morro Grande são classificados como zonas núcleo.

ZONAS DE AMORTECIMENTO E CONECTIVIDADE: são constituídas pelas áreas subjacentes às zonas núcleo. Nelas, todas as atividades desenvolvidas, sejam econômicas ou de qualquer outra natureza, devem se adequar às características de cada zona núcleo, de forma a garantir uma total preservação dos ecossistemas envolvidos. Correspondem a: Áreas de Proteção Ambiental - APAS (estaduais e municipais), Áreas de Proteção aos Mananciais (exceto as áreas urbanizadas), Florestas Maduras, Corredor Ecológico e de Biodiversidade entre os PE da Cantareira e Juqueri, Rede de Parque e Áreas Verdes de São Paulo e de Santo André e as Áreas Prioritárias para a Conservação Marinha.

ZONAS DE TRANSIÇÃO E COOPERAÇÃO: são constituídas pelas áreas externas às zonas tampão e permitem um uso mais intensivo, porém não destrutivo, do solo e seus recursos ambientais. Essas áreas correspondem às restantes, com exceção das grandes manchas urbanas, e são voltadas para o desenvolvimento sustentável.

No processo de revisão da RBCV (2009), houve alterações nos seus limites terrestres, em sua face leste, face oeste e uma expansão nas áreas marinhas; entretanto, essas alterações não estão relacionadas aos limites da área aqui estudada.

Os serviços ambientais, já mencionados como de suma importância e prestados pela RBCV, foram categorizados em linhas funcionais (ALCAMO, 2003), que incluem serviços de provisão (água, alimentos, madeira e fibras), de regulação (clima, controle de inundações e doenças, qualidade da água), serviços culturais (recreacionais, estéticos, espirituais, educacionais) e de suporte (formação do solo, fotossíntese, ciclagem de nutrientes).

Dentre os serviços promovidos, podemos destacar alguns benefícios, tais como: proteção dos mananciais que abastecem a cidade, como as cabeceiras e afluentes dos rios que cortam a área urbana; filtragem do ar poluído; abrigo de grande biodiversidade de espécies; proteção dos solos de áreas vulneráveis, onde se produzem chuvas torrenciais, amenizando as enchentes na malha urbana e os desastres de deslizamentos.

Ao mesmo tempo em que os serviços trazem essa série de beneficios para a metrópole, 
eles estão vinculados a todas as dinâmicas metropolitanas e são influenciados por vetores diretos e indiretos de alteração ambiental, gerados pelo mesmo aglomerado urbano (RODRIGUES, 2006).

De acordo com o Instituto Flroestal - IF, órgão gestor da reserva, hoje a RBCV se encontra ameaçada por diversas causas, como a especulação imobiliária nos municípios; grandes obras de infraestrutura; legislação inadequada e descumprida; regulamentação fundiária precária; extração ilegal de recursos florestais; atividades de mineração; aterros de lixo urbano; poluição atmosférica, causada por zonas industriais e veículos automotores; depredação do ambiente por indivíduos não conscientes e atividades industriais não centralizadas ${ }^{26}$.

A discussão sobre os serviços ambientais em áreas urbanas é comprometida por alguns fatores; o primeiro deles está relacionado à complexidade e às insuficiências da compreensão dos processos relacionados aos serviços. O segundo deriva do fato de as agências privadas terem dificuldades em deles se apropriar para comercializá-los. Além disso, a parte que cabe às agências públicas encontra dificuldade para geri-los e regulamentá-los. E, por fim, existe a condição em que aqueles grupos que mais dependem dos serviços ambientais são socialmente mais vulneráveis e tendem a ser econômica e politicamente menos influentes (ALCAMO, 2003).

Hoje, a gestão da RBCV é formada pelo conselho de gestão, pelo bureau e pela secretaria (RBCV, 2007)

O conselho de gestão é responsável por propor e acompanhar a gestão da reserva, por meio da definição de políticas e estratégias. Procura se configurar como um fórum capaz de incorporar as demandas e propostas dos mais variados segmentos da sociedade, promovendo a gestão participativa preceituada pelo programa MAB.

É composto por 34 membros, sendo 17 representantes de instâncias governamentais e 17 de instâncias não-governamentais. Os representantes do grupo governamental são: seis representantes de governos municipais; dois representantes do Instituto Florestal; um representante da Secretaria de Meio Ambiente do Estado de São Paulo; um do Comitê Estadual da Reserva da Biosfera da Mata Atlântica; um da Empresa Metropolitana de Planejamento do Estado de São Paulo (EMPLASA); um da Companhia de Saneamento Básico do Estado de São Paulo (SABESP); um da Companhia de Tecnologia de Saneamento Ambiental (CETESB); um do Ministério Público Estadual; um da Associação Nacional de Órgãos Municipais de Meio Ambiente (ANAMMA); um da Secretaria da Casa Civil; um do Ministério do Meio Ambiente; um do Conselho Estadual de Meio Ambiente (CONSEMA) e um representante governamental (RBCV, 2007).

Já em relação aos representantes não governamentais, tem-se: uma representação do setor
${ }^{26}$ Informações obtidas em http://www.iflorestsp. br/rbcv/ocintverd.htm, acessado em 14/10/2009 
primário, ocupada pela Federação de Agricultura do Estado de São Paulo (FAESP); uma do setor secundário, ocupada pela Federação das Indústrias do Estado de São Paulo (FIESP); uma do setor terciário, ocupada pela Associação Comercial; uma do Comitê da Bacia Hidrográfica do Alto Tietê; uma do Comitê da Bacia Hidrográfica da Baixada Santista; uma do Comitê da Bacia Hidrográfica dos rios Piracicaba, Capivari e Jundiaí; uma da bancada não governamental do CONSEMA; duas representações da comunidade científica; duas de moradores da região; três de ONGs atuantes na região e três convidados do comitê transitório da RBCV (RBCV, 2007).

Essa quantidade e diversidade de atores de instâncias da sociedade permitem que a RBCV funcione e atue como um espaço de discussões, numa tentativa de amenizar os conflitos de interesses, de modo a contemplá-los de maneira democrática e participativa.

Outra instância do conselho de gestão é o bureau da RBCV. De caráter executivo, é responsável por apoiar o gerenciamento de recursos, por representar publicamente a reserva, elaborar as atividades, organizar as reuniões do conselho e encaminhar as questões para sua deliberação (RBCV, 2007).

Alem do conselho de gestão, existe a secretaria, com a função de coordenação executiva, estando a cargo do Instituto Florestal da Secretaria do Meio Ambiente de São Paulo e tendo o papel de propor e executar programas e projetos no âmbito da RBCV, assessorar seu conselho de gestão e executar as políticas por este definidas (RBCV, 2007).

Do ponto de vista ambiental, as áreas que são mais sensíveis aos impactos causados pela sociedade coincidem com áreas periféricas e periurbanas, onde encontramos índices maiores de exclusão social. Para contemplar essa realidade, a RBCV criou o programa Jovem - Meio Ambiente e Integração Social (PJ-MAIS), buscando envolver a sociedade nas políticas públicas. Trata-se de um programa de educação eco-profissional e formação integral de adolescentes entre 15 e 21 anos de idade, habitantes de zonas periurbanas e de entorno de áreas protegidas da RBCV, em situação de vulnerabilidade social (RBCV, 2006 apud Rodrigues, 2006). O programa é composto por núcleos de educação eco-profissional, os quais são coordenados geralmente pelas prefeituras municipais em parceira com outras instituições do setor privado, não-governamental, acadêmico ou voluntariado.

Outro programa que está ativo é o de Avaliação Subglobal da RBCV, no qual, desde 2008 e com previsão de seguir até 2012, vêm sendo feitas avaliações de diversos programas de RBs para que a metodologia seja aplicada em escalas menores, buscando a consolidação das principais políticas e ações necessárias à gestão integrada. Dentro desse processo, um dos destaques é a avaliação ambiental integrada, que procura realizar uma discussão mais aprofundada sobre alguns dos serviços ambientais prestados pela Reserva, como os de provisão de alimentos, de produtos químicos e remédios naturais, de processos geo-hidrológicos de erosão, deslizamentos e inundações, de serviços 
de regulação da qualidade do ar e serviços culturais de recreação e turismo sustentável (UNESCO, 2010).

O tema do planejamento da paisagem da reserva é mencionado de maneira sucinta no plano de ação definido pela equipe do bureau da RBCV. No Grupo 3, que considera as ações importantes a serem realizadas, um dos temas é o re-zoneamento da $\mathrm{RBCV}$, atualizando-se as áreas-núcleo, tampão e transição. Esperamos que os resultados alcançados e as discussões realizadas na presente pesquisa possam colaborar com o tema. Também está prevista, no mesmo grupo, uma estratégia de aproximação das prefeituras e oficina e/ou tópicos de ensino voltados ao monitoramento e observação do ambiente.

\subsection{3 ÁREAS NATURAIS SIGNIFICATIVAS}

Para melhor caracterizar o trecho oeste da RMSP, podemos destacar três importantes remanescentes de vegetação, os quais consideramos como áreas naturais de extrema importância no contexto regional do trecho aqui selecionado para estudo: Parque Estadual da Cantareira, Reserva do Morro Grande e Morro do Boturuna. São áreas protetoras de diversas espécies vegetais e animais, bem como de significativos mananciais - como ilustram a Figura 11 e o Mapa 01 a seguir. O trecho também possui uma série de outros fragmentos de vegetação menores, como parte da APAs Cajamar, Parque Estadual Juqueri e Parque Estadual do Jaraguá, além de outros parques, zonas e macrozonas de preservação ambiental, ou apenas fragmentos isolados, áreas públicas e particulares, que são apresentados adiante.

O Parque Estadual da Cantareira e a Reserva do Morro Grande são preservados pela lei de Proteção aos Mananciais. Tais unidades de conservação de categoria máxima de proteção foram criadas principalmente para protegerem os recursos hídricos que abastecem a área urbana, bem como para manterem os remanescentes de vegetação.

A grande ameaça à integridade dessas áreas é o acelerado processo de expansão urbana na metrópole de São Paulo e a irregularidade no uso do solo urbano, fenômenos associados que têm como produto a explosiva dissociação entre a oferta de habitação popular e a efetiva constituição de "cidade", devido à omissão do poder público, tanto na oferta de infraestrutura e serviços urbanos quanto no controle adequado sobre o parcelamento do solo urbano (MEYER et al., 2004). 
A Região Norte do trecho estudado, que corresponde às bordas sul, sudeste e sudoeste do Parque Estadual da Cantareira, vem sofrendo, há alguns anos, diversas ações de degradação ambiental por conta da instalação de loteamentos clandestinos. As propriedades particulares situadas nas encostas da serra em zona rural foram sendo parceladas clandestinamente, caracterizando as áreas de habitação precárias da Zona Norte de São Paulo (SILVA, 2005).

Na Serra da Cantareira há um grande contínuo da Floresta Ombrófila Densa Montana (Mata Atlântica) em diversos estádios de regeneração. E em algumas áreas de sua borda há Vegetação Secundária da Floresta Ombrófila Densa Montana (INSTITUTO FLORESTAL DE SÃO PAULO, 2010), que corresponde à cobertura vegetal nativa mais expressiva da área aqui estudada. A vegetação secundária foi originada a partir da regeneração florestal de áreas que foram adquiridas no final do século XIX para o abastecimento de água da cidade de São Paulo (FUNDAÇÃO FLORESTAL, 2009).

O terreno declivoso que marca a serra é uma característica que, provavelmente, limitou a ocupação pela dificuldade de acesso e baixa aptidão agrícola, determinando, consequentemente, a preservação da cobertura vegetal original, em que predominam grandes contínuos florestais, em sua maior parte preservados e em estágio médio a avançado de regeneração.

O Parque Estadual da Cantareira (PEC) é uma Unidade de Conservação criada por meio do Decreto $n^{\circ}$ 41.626/63 (Sistema Nacional de Unidades de Conservação -SNUC), transformada em parque por meio da Lei Estadual 6.884 de 1962 e, posteriormente, em 1968, em Parque Estadual Turístico da Cantareira, pelo Decreto Estadual n ${ }^{\circ} 10.228$. O seu plano de manejo corresponde a um estudo detalhado da sua composição, estrutura, características físicas, biológicas e sociais.

Com uma área de 79,17 km2 e 90,5 km de perímetro, é considerado o maior parque urbano do mundo, abrangendo parte dos municípios de São Paulo (Zona Norte), Caieiras, Mairiporã e Guarulhos. Trata-se de um grande fragmento de Mata Atlântica que abriga diversas espécies de fauna e flora, além de mananciais de água com excelente qualidade. Possui ainda diversos tipos de uso do solo em seu entorno, como sítios, chácaras de recreio, condomínios de alto padrão, pedreiras, áreas densamente urbanizadas e terrenos com mata nativa (FUNDAÇ̃̃O FLORESTAL, 2009). Vale ressaltar que a Serra da Cantareira compreende a área do parque de domínio patrimonial público e diversas propriedades particulares, urbanas e rurais. Portanto, o parque toma a maior parte da serra, mas não toda ela.

De acordo com a Fundação Florestal (2009), a maior fonte de distúrbios ao PEC são as estradas, a Rodovia BR-381 (Fernão Dias) e as estradas da Roseira e de Santa Inês, que cortam o 
remanescente de vegetação e causam atropelamentos e barreiras ao fluxo da fauna, consequentemente dificultando ou inviabilizando o fluxo gênico. Caça, extrativismo, incêndios e assoreamento dos rios são outros problemas enfrentados pela gestão do parque.

Na parte sul do trecho estudado, temos a Reserva Florestal do Morro Grande (RFMG), localizada no município de Cotia (SP), na porção oeste da RMSP. Possui uma área aproximada de $106 \mathrm{~km}^{2}$, somando-se a ela 2,71 km², externos ao seu limite, o que corresponde à ocupação da terra pela estação de tratamento da Sabesp. Contém as cabeceiras do Rio Cotia e é explorada como manancial de abastecimento hídrico para a RMSP. Sua área é recoberta por florestas, em estádio de sucessão secundário, pertencentes ao domínio da Mata Atlântica, ou especificamente, Floresta Ombrófila Densa Montana (VELOSO et al.1997). Possui alguns trechos com poucas perturbações, conectados à Serra de Paranapiacaba e APA Itupararanga. Em 20 de junho de 1981, foi assinada a Resolução 02 de tombamento da Reserva Florestal do Morro Grande pelo Conselho de Defesa do Patrimônio Histórico, Arqueológico, Artístico e Turístico - CONDEPHAAT. Mais recentemente, a Sabesp conseguiu o tombamento da RMG como Reserva da Biosfera, pela inegável importância estratégica em função de sua biodiversidade e mananciais.

Além de sua importância estratégica como protetora de mananciais, a RFMG é uma das áreas-núcleo da Reserva da Biosfera do Cinturão Verde da Cidade de São Paulo, considerada pela UNESCO como área de alta relevância ecológica e humana ${ }^{27}$.

O Morro de Boturuna é hoje tombado pelo CONDEPHAAT com o propósito de preservar áreas de relevante interesse paisagístico, ambiental, turístico e histórico. Assim foi criada a Área Natural Tombada (ANT) Serra do Boturuna ${ }^{28}$.

Essa ANT é um importante patrimônio ambiental, sendo que, em virtude de suas características naturais, constitui-se como um marco na paisagem regional, destacando-se como um padrão geomorfológico diferenciado no Planalto Atlântico. Além disso, possui uma representação significativa na história nacional, pois foi registrada como uma das primeiras áreas de mineração de ouro de aluvião paulista, estimulando as bandeiras para desbravar o sertão em busca de distintos recursos minerais.

O Morro de Boturuna possui uma área correspondente a 11,29 km², e se localiza nos limites dos municípios de Santana de Parnaíba e Pirapora do Bom Jesus, abrangendo também o município de Araçariguama, referente à sua zona de amortecimento, com um perímetro de 300 metros ${ }^{29}$.

Com grande valor paisagístico e importante área natural remanescente, esse monte quartzítico, dotado de solos pobres, densas florestas e recursos hídricos, caracteriza-se
${ }^{27}$ Instituto Florestal de São Paulo, informações obtidas no site http://iflorestsp.br/Rbcv/index. htm), acessado em 20/04/2009.

${ }^{28}$ Segundo a Resolução da Secretaria da Cultura n 17, de 04 de agosto de 1983 - conforme processo CONDEPHAAT nº 22328/82.

${ }^{29}$ Informação obtida no site http://sufrutoverdeus.org.br/meioambiente.html, acessado em $15 / 09 / 2011$

${ }^{30}$ Segundo a Resolução da Secretaria da Cultura $n^{\circ}$ 17, de 04 de agosto de 1983 - conforme processo CONDEPHAAT n ${ }^{\circ} 22328 / 82$ 
pelo tipo de mata do domínio das florestas atlânticas de planalto e um refúgio da fauna regional ${ }^{30}$ (CONDEPHAAT, 1983).

Outras áreas de proteção encontradas no trecho estudado são as APAs, que correspondem a uma categoria de unidades de conservação criada para assegurar o bem estar das populações humanas, como também a proteção, recuperação e conservação dos recursos naturais. É considerada uma unidade de uso direto dos recursos naturais, em que são permitidas a exploração e a ocupação, conforme as normas específicas que regulam a unidade ${ }^{31}$.

Grande parte da APA Cajamar está incluída no norte da área estudada. Ela foi criada pela Lei Estadual 4.055, de 1984, por possuir características e atributos de conservação e preservação. Abrange parte da Serra do Japi e da Serra dos Cristais, que se estendem pelas regiões norte e noroeste do município de Cajamar, apresentando uma paisagem de morros cobertos com densa vegetação. Possui uma área de $134 \mathrm{~km}^{2}$. Guarda mananciais para abastecimento público representados pelos rios Juqueri-Mirim, Juqueri e Ribeirão das Lavras, onde são abundantes os recursos hídricos e as áreas de cabeceiras de diversos cursos d'água ${ }^{32}$. Esta APA é contígua a outras, como APA Piracicaba/Juqueri-Mirim e APA Cabreúva, de grande importância para região, mas que não foram incluídas na área estudada.

Outro parque inserido na área, este integralmente, é o Parque Estadual Juqueri, também considerado pelo zoneamento da RBCV como área núcleo. Com $20 \mathrm{~km}^{2}$, é uma reserva natural muito próxima da área urbana e apresenta um rico mosaico de vegetações, como campos cerrados e Mata Atlântica. Corresponde a um enclave de cerrado no domínio de Mata Atlântica, sendo uma das UCs mais importantes da RMSP, pois representa um testemunho do final do Pleistoceno, ou seja, de climas passados. Como se localiza próximo da Serra da Cantareira, existe entre os dois parques um corredor que, por se tratar de uma área desocupada, recoberta por vegetação, é utilizado por animais e acaba por conectar ambas as Unidades de Conservação; entretanto, não é uma área protegida, estando sujeito a diversas outras formas de ocupação.
${ }^{31}$ Secretaria Estadual do Meio Ambiente. Informação obtida no site http://www.ambiente.sp.gov. br/apas/oque_apa.htm, acessado em 01/01/2012.

${ }^{32}$ Secretaria Estadual do Meio Ambiente. Informação obtida no site http://www.ambiente. sp.gov.br/apas/cajamar.htm, acessado em 01/01/2012.

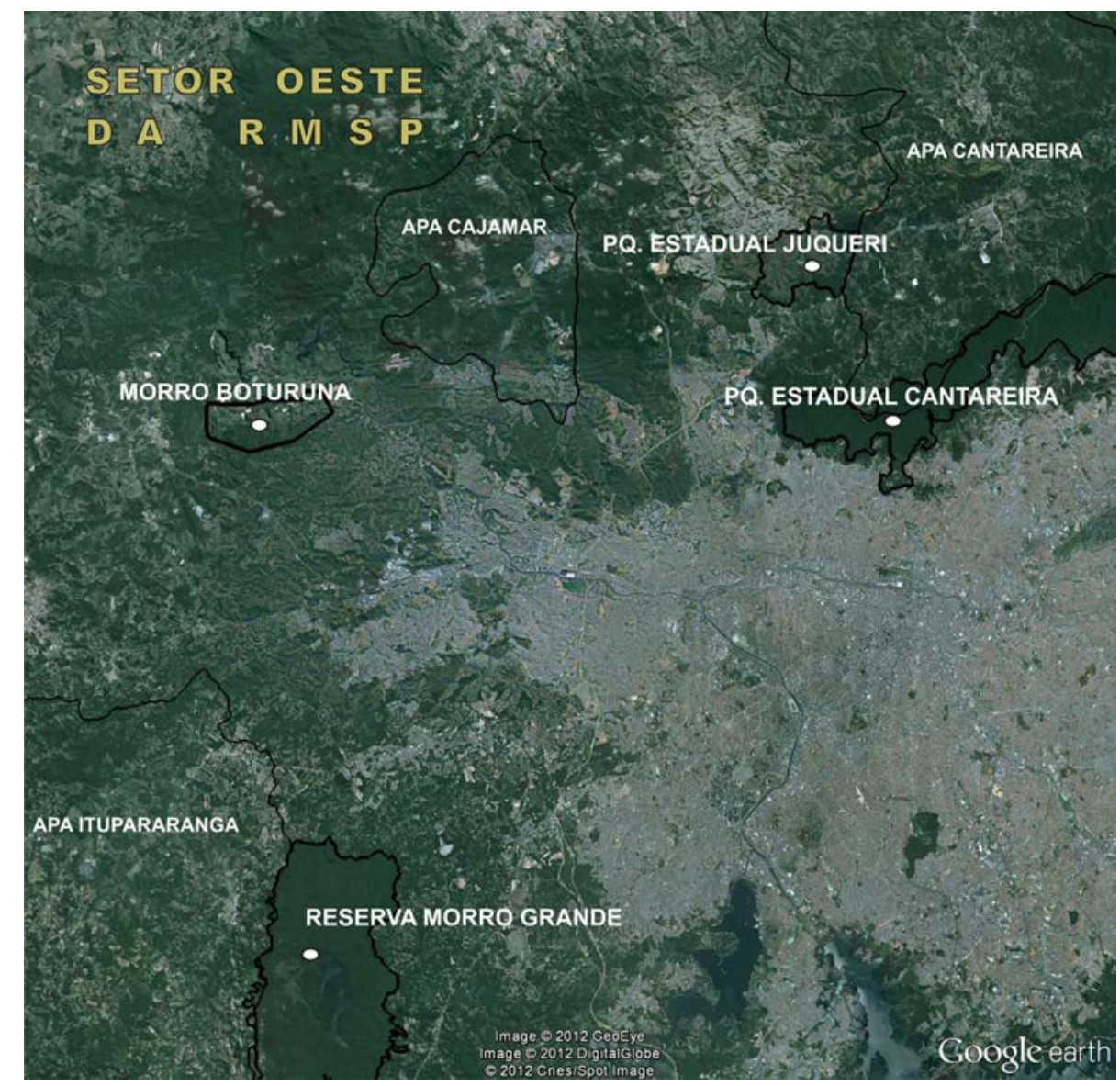

FIGURA 9: Áreas de Proteção: Parque Estadual da Serra da Cantareira, Reserva do Morro Grande, Parque Estadual Juqueri, APA Itupararanga, APA Cajamar e APA Sistema Cantareira, localizadas no trecho Oeste da RMSP. (Fonte: google Earth, acessado em 10/01/2012. 
Outro parque estadual presente na área é o do Jaraguá. Criado em 1961 em torno do Pico do Jaraguá, é também considerado uma zona núcleo da RBCV. Trata-se de uma reserva florestal com aproximadamente $5 \mathrm{~km}^{2}$ de área e constitui um dos últimos remanescentes de Mata Atlântica em áreas urbanas da cidade de São Paulo.

A APA Itupararanga foi criada pela Lei Estadual n 10.100 , de 01 de dezembro de 1998, e alterada pela Lei Estadual 11.579, de 02 de dezembro de 2003, para proteger a represa de mesmo nome, localizada no alto curso do rio Sorocaba. Inclui os municípios de Alumínio, Cotia, Ibiúna, Mairinque, Piedade, São Roque, Vargem Grande Paulista e Votorantim, com área total de 933,57 $\mathrm{km} 2$, sendo responsável por parte do abastecimento hídrico da região. A APA não faz parte da área estudada, entretanto está ligada diretamente ao arco estudado pelo lado oeste da Reserva do Morro Grande, município de Cotia, e pela sua parte no município de Vargem Grande Paulista, de forma que alguns dos processos ecológicos que ocorrem no trecho estudado estão relacionados aos da APA, e vice versa.

\subsubsection{AVIFAUNA E MASTOFAUNA NO SETOR OESTE DA RESERVA DA BIOSFERA DO CINTURÃO VERDE (RBCV)}

Neste item, caracterizamos a avifauna e a mastofauna de maior porte de provável ocorrência na região Oeste da RBCV por meio de dados secundários. De modo geral, pudemos avaliar as implicações da estrutura da paisagem e suas transformações para a manutenção da fauna. Tais informações apresentam o potencial ecológico da região, as espécies endêmicas e os graus de ameaça de extinção.

\section{-CARACTERÍSTICAS}

\section{AVIFAUNA}

As aves constituem uma classe de animais vertebrados, tetrápodes, endotérmicos e ovíparos, caracterizados principalmente por possuírem penas, apêndices locomotores anteriores modificados em asas, bico córneo e ossos pneumáticos (HICKMAN JR. et al., 2004). São reconhecidas aproximadamente 11.000 espécies de aves que habitam todos os ecossistemas do globo. O Brasil 
é o segundo país em número de aves no mundo, com 1.834 espécies (CBRO, 2011). Destas, 808 podem ser encontradas no Estado de São Paulo (FIGUEIREDO, 2011).

O Brasil também apresenta uma alta taxa de endemismo, com mais de 10\% $(\mathrm{n}=199)$ das espécies ocorrendo exclusivamente em território nacional. Em relação às ameaças, $12 \%(n=221)$ sofrem de algum tipo de ameaça em nível mundial (IUCN, 2008) e acima de 6\% (n=124), em nível federal (MMA, 2008). Já no Estado de São Paulo, cerca de 26\% (n=212) das espécies estão sob alguma ameaça. A constante destruição dos ecossistemas naturais, diminuindo e isolando os habitats disponíveis, além da caça e do tráfico estão entre as principais ameaças para a avifauna.

Entre os vertebrados, as aves são os animais mais fáceis de serem percebidos na natureza, chamando a atenção pela plumagem ou pela grande variedade de cantos (VERNER,1981). Devido às interações com a estrutura da vegetação, a presença de algumas espécies de aves e a ausência de outras pode indicar se uma área está ou não bem conservada. Assim, esse grupo é habitualmente utilizado em monitoramentos de impactos ambientais, já que respondem rapidamente às alterações no seu ambiente (UEZU et al. 2005).

\section{MAMÍFEROS DE MAIOR PORTE}

Os mamíferos apresentam uma surpreendente diversidade de formas e uma gama de variações morfológicas e fisiológicas, o que lhes possibilitou a adaptação a diferentes ambientes e a colonização desde áreas de florestas tropicais úmidas até habitats savânicos, climaticamente áridos e polares (EISENBERG e REDFORD, 1989; POUGH, 2003; KEMP, 2005).

Ocupam uma variedade de nichos ecológicos, com espécies terrestres e aquáticas que atuam como predadores de topo de cadeia (superpredadores), predadores secundários (mesopredadores) consumidores primários (herbívoros), além de desempenharem importante papel como dispersores de sementes e saprófagos (BEGON et al., 2007). Compartilham uma longa lista de caracteres, como a presença de glândulas mamárias, um único osso mandibular e a presença do neocórtex cerebral, o que os distingue de seus parentes mais próximos e define a classe Mammalia como um táxon monofilético (KEMP, 2005).

A classe Mammalia é subdividida em quatro subgrupos funcionais para estudos ecológicos e zoológicos que consideram o tamanho corporal e os aspectos ecológicos gerais: pequenos mamíferos terrestres (pequenos roedores e marsupiais); mamíferos voadores (Quirópteros); mamíferos marinhos e mamíferos terrestres de maior porte, como onças e veados. Estes últimos necessitam de grandes áreas para manter populações viáveis, apresentam alta vagilidade (i.e., alta tendência de um 
organismo ou população de mudar sua localização ou distribuição com o tempo), exibem baixa densidade populacional, apresentam tempo longo de geração (NOSS et al., 1996; CULLEN-JR. et al., 2000; PERES, 2001) e são especialistas de habitat ou guilda trófica.

Poucas áreas no mundo, em particular as florestas tropicais, ainda sustentam uma comunidade completa e preservada de grandes mamíferos (MORRISON et al., 2007).

A região Neotropical abriga uma das mais diversas faunas de mamíferos do planeta. Considerando todos os subgrupos (mamíferos voadores, marinhos, pequenos e de maior porte), abriga cerca de $24 \%$ das espécies viventes no planeta. É também composta por um alto número de táxons endêmicos, sendo mais de 80\% das espécies restritas a essa região (1994;WILSON e REEDER, 1993).

No Brasil, existem 652 espécies de mamíferos descritas (WILSON e REEDER, 2005 REIS et al., 2006), das quais 10,6\% $(n=69)$ encontram-se sob algum grau de ameaça federal (MMA, 2008). Já em nível estadual, das 38 espécies (16\%) que se encontram ameaçadas, 22 (9,5 \%) são mamíferos de maior porte (SMA, 2010). O grau de ameaça e a importância ecológica tornam evidente, portanto, a necessidade de se incluir informações sobre esse grupo em projetos de recuperação ambiental.

\section{-MATERIAL E MÉTODO}

O material utilizado para a elaboração da lista de aves e mamíferos de maior porte com provável ocorrência para a área de estudo foi obtido por meio de revisão bibliográfica de levantamentos realizados nas áreas de influência da região estudada, sendo priorizados os que ocorreram em Unidades de Conservação municipais, estaduais ou federais (levantamentos publicados ou planos de manejo). Também, foram utilizados dados dos levantamentos do Estudo de Impacto Ambiental do trecho Norte do Rodoanel, que constituiu informação importante para a elaboração da lista final.

Assim, foram considerados relevantes os levantamentos realizados em sete áreas, que constituíram a base de informação das espécies.

Abaixo, são listados os levantamentos:

1) Reserva Florestal do Morro Grande (RFMG)

Sobre a Reserva Florestal Morro Grande já descrita e já apresentada no item anterior, temos que o levantamento geral de aves no local foi realizado por Develey e colaboradores (2006) e o da mastofauna, por Negrão e Valladares-Pádua (2004) e Paula et al. (2010). 
2) Parque Estadual da Cantareira (PEC)

No Parque Estadual da Canteira, também já apresentado, foram utilizados três trabalhos sobre as aves do PEC para compor a lista base da AII: o levantamento preliminar realizado por Graham (1992), alguns registros adicionais mais recentes reportados por Antunes et al. (2006) e os dados provenientes do EIA/RIMA Rodoanel Norte (JGP/Prime 2010). Para a mastofauna, foram utilizados os dados provenientes da revisão do Plano de Manejo da Cantareira (Fundação Florestal, 2009) e do EIA/RIMA Rodoanel Norte (JGP/Prime 2010).

3) Reserva Biológica da Serra do Japi (REBIO)

A Reserva Biológica Municipal da Serra do Japi é uma Unidade de Conservação de Proteção Integral. Situa-se na Serra do Japi, em Jundiaí, Estado de São Paulo, dentro dos limites da Área de Proteção Ambiental (APA) da cidade e possui 20,71 km2. A vegetação da unidade é formada por floresta estadual semidecidual de altitude, com transição para floresta estacional semidecidual e com a presença de elementos provenientes de floresta ombrófila densa (GOLDENBERG e VARASSINI, 2001)

Os dados provenientes estão no Plano de Manejo (Ambiental Consulting, 2008) e são oriundos de Silva (1992) para a avifauna e Marinho-Filho (1992) para mastofauna.

4) Parque Estadual Juquery (PEJU)

O Parque Estadual Juquery, já descrito, teve o levantamento da avifauna realizado por Figueiredo e colaboradores (2000); não existem dados disponíveis sobre a mastofauna.

5) Parque Ecológico do Tietê (PET)

O Parque Ecológico do Tietê possui uma área de $12,5 \mathrm{~km} 2$ distribuídos ao longo das planícies de inundação do Rio Tietê, numa porção hoje em dia inserida na cidade de São Paulo. A presença ainda massiva de aves associadas a ambientes aquáticos, apesar de toda descaracterização ambiental sofrida no local ao longo dos anos pelo avanço da cidade, torna essa área de vital importância para muitas espécies.

Infelizmente, não existem publicações formais disponíveis para o local, mas um grupo de estudos paulista (Centro de Estudos Ornitológicos - CEO) realizou levantamentos voluntários no parque e disponibilizou as informações em seu website (http://www.ceo.org.br/parqu/listas/ Tiete-PE.xls).Também não existem dados disponíveis sobre a mastofauna da área. 
6) Parque Anhanguera (PA)

No Parque Anhanguera os levantamentos de aves e mamíferos foram realizados pelo Departamento de Parques e Áreas Verdes de São Paulo (São Paulo, 2010).

7) Parque Estadual do Jaraguá (PEJ)

No Parque Estadual do Jaraguá o levantamento de aves foi feito por Pense e Carvalho (2005) e o de mastofauna retirado do EIA/RIMA Rodoanel Norte (JGP/Prime, 2010).

Para complementação das informações, ainda foram considerados os dados provenientes de dois levantamentos realizados na região metropolitana de São Paulo, nos municípios de Caucaia, Embu e Taboão da Serra (FUSP/FAU-USP, 2009; ENCIBRA, 2010).

No caso da avifauna, as espécies foram classificadas de acordo com o grau de sensibilidade às perturbações antrópicas (sensu STOTZ et al., 1996), endemismo aos biomas brasileiros (BROOKS et.al., 1999; SILVA, 1997) e presença em listas oficiais de espécies ameaçadas de extinção (IUCN, 2008; MMA, 2008; SMA, 2010). A classificação taxonômica e a nomenclatura científica das espécies seguem o Comitê Brasileiro de Registros Ornitológicos (2011).

A mastofauna foi classificada segundo seu endemismo (REIS et al. 2006), uso de habitat (WILSON e REEDER, 2005; REIS et al., 2006) e a presença em listas oficiais de espécies ameaçadas de extinção (IUCN, 2008; MMA, 2008; SMA, 2010). A classificação taxonômica e a nomenclatura científica seguem Wilson e Reeder (2005) e Reis et al. (2006).

\section{-RESULTADOS}

Avifauna

Após a revisão dos dados secundários, foi consolidado um total de 396 espécies de possível ocorrência na região da área de estudo, distribuídas em 23 Ordens e 66 Famílias. Esse número representa 49\% das 808 espécies de ocorrência para o Estado de São Paulo (FIGUEIREDO et al., 2011).

As famílias com maior representatividade de táxons são: Tyrannidae, com 44 espécies (11,1\%), Thraupidae, com 28 espécies (7,1\%) e Furnaridae, com 22 espécies (5,6\%). Além disso, destaca-se a grande quantidade de rapinantes das Ordens Accipitriformes, Falconiformes e Pandionidae, com 24 espécies (6,1\%), das quais se sobressaem o florestal de grande porte gaviãopega-macaco (Spizaetus tyrannus) e os raros de menor porte, gavião-de-sobre-branco (Amadonastur 
lacernulatus) e o gavião-pombo-pequeno (Amadonastur lacernulatus).

De todas as espécies compiladas, 100 (25,3\%) são consideradas endêmicas, sendo 99 (25\%) da Mata Atlântica e apenas uma, a gralha-do-campo (Cyanocorax cristatellus), do Cerrado. A grande proporção de espécies endêmicas da Mata Atlântica indica que a avifauna regional se encontra ainda preservada. Não obstante, a presença de espécies endêmicas deve ser considerada como um aspecto decisivo para o reconhecimento da importância regional de uma área para a conservação no contexto global (STRAUBE e URBEN-FILHO, 2005).

A gralha-do-campo, única espécie endêmica do Cerrado na lista de aves da região, tem se beneficiado com o desmatamento e vem expandindo sua área de distribuição nos últimos anos (WILLIS e ONIKI, 1987), sendo encontrada até no litoral de São Paulo (inf. pess. Celso H. F. Parruco). Por outro lado, foram registradas quatro espécies exóticas, todas típicas de ambientes abertos e/ou antropizados: garça-vaqueira (Bubulcus ibis), pomba-doméstica (Columba livia), bicode-lacre (Estrilda astrild) e pardal (Passer domesticus),

Das 387 espécies de possível ocorrência na região, 50 (12,6\%) encontram-se sob alguma ameaça de extinção. Destas, seis espécies estão presentes na lista da fauna brasileira ameaçada de extinção, sendo que apenas a pararu-espelho(Claravis geoffroyi) possui status de criticamente ameaçada. Esta espécie de pombo raro é intimamente ligada a florestas com alto grau de preservação e, aparentemente, é dependente das frutificações periódicas de bambus nativos nas florestas de altitude do sudeste do país (SICK, 1997). Na presente compilação, essa espécie esteve presente apenas no P.E.Cantareira. Entretanto, trata-se de um registro histórico de pele de museu, sendo que não há outros mais recentes no país.

Uma espécie está classificada como "em perigo" em nível estadual, o caboclinho-de-papobranco (Sporophila palustris), que habita paisagens abertas, como capinzais altos, banhados e capinzais úmidos. As populações residentes se encontram nos campos sulinos, e os registros em São Paulo são provavelmente de migrantes de inverno ou indivíduos vagantes, mas o conhecimento sobre os movimentos migratórios dessa espécie é bastante limitado (BRESSAN et al., 2010). Neste estudo, o caboclinho-de-papo-branco foi registrado na única área de estudo com fisionomia de Cerrado, o P. E. Juquery.

As outras quatro espécies estão classificas como "vulneráveis" à extinção, sendo raras ou pontuais: o gavião-pombo-pequeno (Amadonastur lacernulatus), o papagaio-de-peito-roxo (Amazona vinacea), o pixoxó (Sporophila frontalis) e a cigarra-verdade (Sporophila falcirostris).

Das espécies ameaçadas em nível mundial (IUCN, 2008), 27 encontram-se sob algum tipo de ameaça (uma criticamente ameaça; uma em perigo; sete vulneráveis; dezoito quase ameaçadas). 
Já em nível estadual (SMA, 2010), 39 espécies sofrem algum tipo de ameaça (seis criticamente ameaçadas; três em perigo; quinze vulneráveis; quinze quase ameaçadas). Entre as espécies criticamente ameaçadas para o estado, estão o pixoxó (Sporophila frontalis) e a cigarra-verdadeira (Sporophila falcirostris), espécies raras que possuem associações com taquaras, principalmente durante a frutificação de taquaras nativas dos gêneros Merostachys, Bambusa e Chusquea. A maior ameaça para essas espécies é causada pela excessiva captura e comércio ilegal, além da perda e fragmentação de habitats florestais (MMA, 2008).

Com relação à sensibilidade das espécies de aves às perturbações ambientais, 178 (46,1\%) possuem média sensibilidade e $35(9,1 \%)$, alta sensibilidade. Já as de baixa sensibilidade totalizam $173(44,8 \%)$ espécies. Essas características, juntamente com a proporção de espécies endêmicas e/ ou ameaçadas, demonstram que as comunidades de aves nas áreas amostradas, assim como o próprio ambiente em que se encontram, estão em um bom grau de preservação. Ainda, apesar da grande proporção de espécies com baixas exigências ecológicas, as áreas estudadas possuem um grande número de espécies com dificuldade e/ou incapazes de permanecer em ambientes antropicamente perturbados.

\section{MASTOFAUNA}

No total, foi possível registrar 38 espécies de mamíferos de maior porte que correspondem a 86,4\% (n=44) de espécies esperadas para a região (2011; REIS et al., 2006), distribuídas em 19 famílias e oito ordens.

Dessas espécies registradas, quatro são de tatus (Ordem Cingulata), uma é de preguiça, uma de tamanduá (Ordem Pilosa), oito são de macacos (Ordem Primate), onze são da Ordem Carnívora, uma espécie é da Ordem Perissodactyla, três pertencem à Ordem Artiodactyla, sete espécies são roedores (Ordem Rodentia) e duas são coelhos (Ordem Lagomorpha).

Duas espécies de macacos, o bugio (Allouata clamitans) e o sagüi-da-serra-escuro (Callithrix aurita), são endêmicas do bioma Mata Atlântica. As demais apresentam distribuições mais amplas, podendo, inclusive, ocorrer por todo território nacional, em áreas de habitat natural. Por outro lado, três espécies foram introduzidas na área, o ratão-do-banhado (Myocastor coypus), o sagüi-doCerrado (Callithrix penicillata) e o sagüi-comum (Callithrix jacchus), e uma espécie é considerada exótica, a lebre-europeia (Lepus europaeus).

No caso do ratão-do-banhado (M. coypus), trata-se de introdução realizada no estado de São Paulo há algumas décadas, com a finalidade de criar os animais para obtenção de peles. 
Animais escapados dos criadouros se estabeleceram em toda a região ao redor da grande São Paulo. A espécie, embora silvestre, é nativa do sul do Brasil. Já o sagüi-do-Cerrado (C. penicillata) ocorre naturalmente desde o Maranhão até o leste do Mato Grosso e norte de São Paulo, enquanto o sagüi-comum (C. jacchus) possui distribuição original no nordeste brasileiro. A espécie nativa da região, habitante da Floresta Atlântica de São Paulo, sul de Minas Gerais e Rio de Janeiro, o sagüida-serra-escuro (C. aurita), está localmente extinta em muitas localidades. Tanto C. penicillata quanto C. jacchus, têm sido criadas ilegalmente e frequentemente soltas em qualquer mata pelos próprios infratores, quando os animais perdem o encanto ou passam a dar demasiado trabalho. O resultado é que parece mais fácil encontrar uma das duas espécies introduzidas nessa região do Estado que a espécie nativa, que está ameaçada. Quanto a lebre-européia (Lepus europaeus), natural da Europa, a espécie foi introduzida na década de 80 nos estados do sul do Brasil, atualmente sendo registrada no Estado de São Paulo.

Das 38 espécies de possível ocorrência para a região, 15 (39,5\%) encontram-se sob algum grau de ameaça ou deficiente em dados. Destas, cinco são citadas na lista de espécies ameaçadas de extinção em nível federal (MMA, 2008), o sagüi-escuro-da-serra (Callithrix aurita), o sauá (Callicebus personatus), a jaguatirica (Leopardus personatus), o gato-do-mato-pequeno (Leopardus tigrinus) e a onça-parda (Puma concolor), todas consideradas vulneráveis a extinção. Outras três espécies estão presentes na lista de espécies mundialmente ameaçadas (IUCN, 2008), o sagüi-escuro-da-serra (Callithrix aurita), o gato-do-mato-pequeno (Leopardus tigrinus) e a anta (Tapirus terrestris), sendo as três avaliadas como vulneráveis a extinção. O veado-mateiro (Manzama americana), por sua vez, é uma espécie considerada deficiente em dados. Já em nível estadual, 14 espécies estão presentes na lista das espécies da fauna ameaçada de extinção (SMA, 2010), sendo seis consideradas vulneráveis, o sagüi-escuro-da-serra (Callithrix aurita), a jaguatirica (Leopardus tigrinus), o gato-do-mato-pequeno (Leopardo tigrinus), a onça-parda (Puma concolor), a anta (Tapirus terrestris) e o veado-mateiro (M. americana). Seis espécies estão classificadas como quase ameaçadas, o macaco-prego (Cebus nigritus), o Sauá (Callicebus nigrifrons), o bugiu (Allouata clamitans), a lontra (Lontra longicaudis), o cateto (Pecari tajacu) e a paca (Cuniculus paca). Outras duas espécies são consideradas deficientes em dados, o tatu-de-rabo-mole (Cabassous tatoutay) e o furão (Galictis cuja).

Uma parcela significativa da comunidade de mamíferos de maior porte depende de habitats florestais, mostrando-se extremamente susceptível à perda e fragmentação. De forma geral, os grandes e médios mamíferos, como os felinos, os canídeos e os porcos, possuem grande capacidade de deslocamento (alta vagilidade) e alta tolerância a diferentes tipos de habitats naturais. São espécies 
que podem facilmente colonizar paisagens compostas de mosaicos florestais e matrizes permeáveis, desde que a porcentagem de cobertura florestal seja representativa, pois procuram esta fitofisionomia em busca de abrigo e de recursos alimentares. A manutenção de populações viáveis requer que as áreas sejam conservadas e mantidas protegidas contra a caça. Os primatas, a paca (C. paca), a anta ( $T$ terrestris) e a lontra (L. longicaudis) são também exemplos de espécies que dependem da manutenção de grandes áreas florestais para sua permanência na região. Mamíferos arborícolas, como os primatas e as preguiças, são mais exigentes quanto a o habitat e à distribuição, apresentando capacidade de deslocamento mais limitada, restringindo-se somente a ambientes florestais.

A comunidade da região de estudo também abriga espécies pertencentes a guildas tróficas diferentes. Essa diversidade de hábitos alimentares demonstra haver uma variedade de nichos e habitats na região de estudo que permite a ocorrência de espécies com requerimentos diferenciados. A presença dessas espécies indica ainda a existência de alguns refúgios (i.e., habitats adequados) em alguns fragmentos da região, apesar da evidente degradação de muitos deles.

\section{2 ÁREA DE ABRANGÊNCIA DO ESTUDO}

\subsubsection{SELECC̃̃O E DEFINIC̣ÃO}

Após o contexto regional ter sido evidenciado, a segunda etapa do processo de planejamento para o desenvolvimento de um sistema de corredores, proposto por Hellmund $(1993 ; 2006)$ e aqui seguido, consiste na indicação da área de abrangência do estudo e nas definições gerais dos objetivos que esse sistema poderá atender.

Os objetivos gerais desse planejamento são conservar e recuperar todas as áreas com valor ecológico e aquelas vulneráveis a inundações e deslizamentos que ainda hoje não foram ocupadas, bem como maximizar a conectividade entre os fragmentos, especialmente os maiores, tanto aqueles localizados na área estudada como no entorno; mas também entre os fragmentos menores,

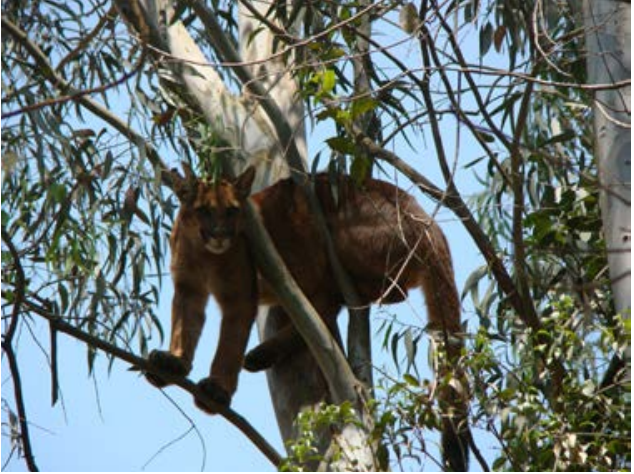

Legenda: Onça Parda ( Puma concolor) encontrada em árvore próxima a

condomínio em Franco da Rocha - SP Foto Instituto Florestal de São Paulo - IF Nov 2011. 
salvaguardando as respectivas diferenças de conectividade.

Embora a área de abrangência não inclua todas as APAS e parques estaduais mencionadas no contexto regional, além da Serra do Mar e de toda a APA Cantareira, pela proximidade e pontos de conexões, sabemos que interferem na dinâmica ecológica da área estudada.

Tal contexto pode ser visualizado no Mapa 1 a seguir. A área de abrangência é marcada em linhas tracejadas, para indicar que se trata de um sistema aberto, com seu limite ancorado nas duas áreas de proteção, Reserva Morro Grande e parte oeste do Parque Estadual da Cantareira. Mas a área de interferência e de atuação, para o estudo de conectividade e de um sistema de corredores ecológicos, estende-se para além dos traços.

Importante esclarecer que o recorte da área de estudo corresponde a um ensaio, realizado primordialmente entre três reservas principais e as demais elencadas, mas com implicações para além delas, já que se trata de uma investigação a respeito das relações entre os processos ecológicos. Ou seja, a conectividade que se busca implementar não se restringe aos limites marcados, avança para os arredores e assim por diante, causando interferências regionais. Assim, os fluxos do sistema de corredores se dão no eixo norte-sul, mas também nos eixos transversais.

A definição da área de abrangência do estudo foi feita a partir de alguns critérios já discutidos no início do capítulo. Por ser a RBCV muito extensa, não foi possível realizar a pesquisa em toda a área, que foi criada com 73 municípios paulistas, mas, com a Revisão do Zoneamento (2009), passou a ter 78 .

Em primeiro lugar, definimos previamente que a pesquisa seria realizada em uma área periurbana à grande matriz da RMP, devendo conter fragmentos florestais e uma condição não completamente urbanizada que justificasse uma discussão de conservação de elementos naturais (vegetação, abrigo de animais, nascentes, rios e riachos, etc.). A partir dos dados do mapeamento de uso do solo (EMPLASA, 2006), identificamos que a área selecionada apresentava essas características, possuindo uma dinâmica típica de área que circunda uma grande metrópole, com partes que se encontram protegidas por instrumentos legais federais, estaduais e municipais (Áreas de Preservação Permanente - APPs, Unidades de Conservação, APAs, Parques Estaduais, Parques Municipais, Área de Proteção aos Mananciais, Zoneamentos de Planos Diretores Municipais). Porém, sofre grandes pressões urbanas, em especial pela presença de rodovias e pela proximidade de grandes centros, os quais atuam como vetores de crescimento e aumento da ocupação urbana na área.

O zoneamento da Reserva da Biosfera do CinturãoVerde da Mata Atlântica de São Paulo 
MAPA 1 - ÁREA DE ESTUDO INSERIDA NO LIMITE OESTE DA RESERVA DA BIOSFERA DO CINTURÃO VERDE

Projeçăo Universal Tranversal Mercator ( UTM) Elipsoide South American Datum (SAD) 1969 Organizaçăodos dados e Elaboração:

Júlia R. Leite, (2011).

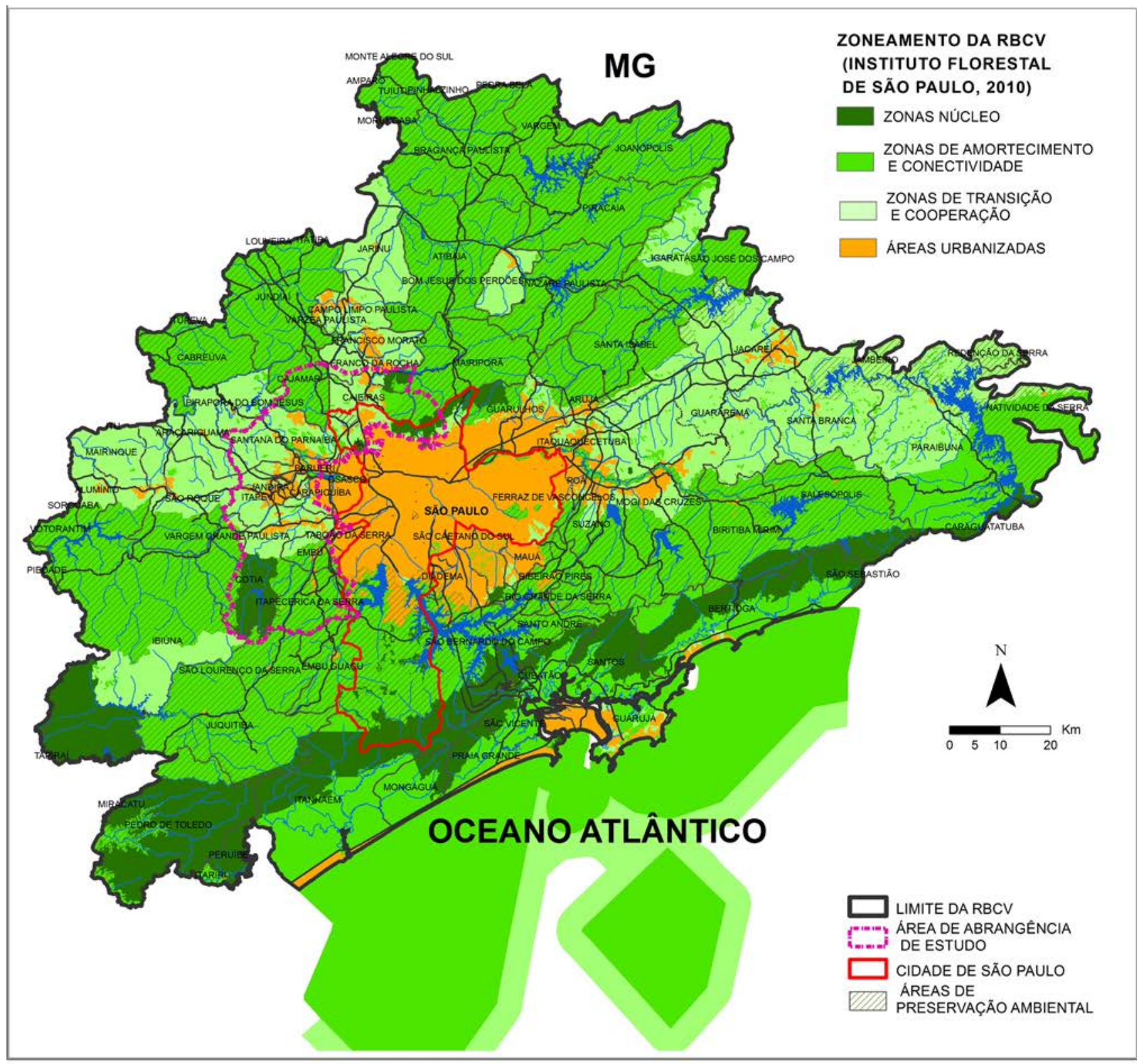


(2009) nos possibilitou definir o limite da área aqui estudada, sendo que procuramos incluir os fragmentos de vegetação mais significativos do setor oeste da RMSP, de modo a identificar o potencial ecológico do arco estudado e ancorar o sistema de corredores. Assim, os trechos maiores e mais bem conservados são consideradas pelo Zoneamento da Reserva da Biosfera do Cinturão Verde (LINO et al., 2009) como as áreas núcleo, também amparadas pela legislação ambiental, como o Parque Estadual da Cantareira, a Reserva Estadual do Morro Grande, Área Natural Tombada Boturuna, Parque Estadual Juqueri, Parque Estadual do Jaraguá e APA Cajamar, que são, portanto, fragmentos de grande importância ecológica e biológica para a RMSP. Há no interior do trecho outros muitos remanescentes de vegetação, que, por sua composição vegetal e estruturas, são também capazes de promover conexões entre as áreas protegidas e entre si.

Nesta perspectiva, a área escolhida, bem como seus remanescentes e espaços abertos de edificações (áreas semi-naturais) foram alvo de análises da paisagem.

Também foi incluída no trecho apenas a parte oeste da Serra da Cantareira, de modo a restringirmos as análises e discussões para esse setor da RMSP. A Reserva do Morro Grande acabou sendo incluída integralmente para que todo seu entorno pudesse ser avaliado, já que existem vários fragmentos menores em uma área mais rural do que urbana.

Para a delimitação da linha divisória da área de abrangência do estudo, partimos do zoneamento proposto pela RBCV, o qual, como já colocado anteriormente, propõe a seguinte classificação: Zonas de Transição e Cooperação; Zonas de Amortecimento e Conectividade; Zonas Núcleo. Sendo assim, o limite da área a ser estudada, que tangencia a matriz urbana, corresponde ao Limite definido pelo IF da Zona de Transição e Cooperação da RBCV.

Outro fator que nos levou a incluir apenas uma parte do Parque Estadual da Serra da Cantareira e da APA Cajamar foi o fato de ambas as áreas já serem protegidas pela legislação, possibilitando direcionar, desta forma, o alvo da investigação para a paisagem existente e seus fragmentos de vegetação.

A fim de facilitar a obtenção de dados (EMPLASA, 2006) relativos à ocupação do solo, base física e biológica e das fotografias aéreas ortorretificadas, respeitamos o limite da RMSP para delimitar a borda oeste da área de abrangência.

A identificação do rio Cotia como um elemento da paisagem de importância estrutural para a conectividade estrutural e ecológica fez com que sua foz no rio Tietê fosse incluída na área de estudo, mesmo se tratando de um trecho da RMSP altamente urbanizado e que não está incluído na zona de amortecimento pelo RBCV.Também a identificação da APA de Cajamar como zona de 
amortecimento e conectividade da RBCV e do Parque Estadual do Juqueri fez com que o limite norte da área de abrangência do estudo fosse ampliado, visando ancorar o sistema.

Embora o contexto hidrográfico não tenha sido um elemento utilizado para a delimitação da área de abrangência, é importante ressaltar que ela está incluída nos limites da Bacia Hidrográfica do Alto Tietê, mais precisamente, contendo trechos que pertencem à divisão das sub-bacias: PenhaPinheiros, Cotia-Gurapiranga e Jusante-Pinheiros. Essa divisão, porém, não foi determinante no desenho da área de estudo.

\subsubsection{UNIDADES ADMINISTRATIVAS}

Na área determinada como de abrangência do sistema de corredores estão incluídos limites de dezessete municípios da RMSP, mas apenas quatro deles possuem sua área inteira dentro do trecho aqui estudado - Barueri, Caieiras, Jandira e Santana do Parnaíba. Os municípios integrantes, a área que ocupam e o percentual correspondente à área total municipal estão discriminados na Tabela 1, e a ilustração dos municípios pode ser visualizada no Mapa 2. 
TABELA 1: Municípios incluídos na Área de Abrangência do Estudo (EMPLASA, 2006).

\begin{tabular}{|c|c|c|c|}
\hline IDENTI| & $0 \quad$ MUNICÍPIO & ÁREA (km2) & \%DA ÁREA TOTAL MUNICIPAL \\
\hline 1 & BARUERI & 57,71 & $87,14 \%$ \\
\hline 2 & CAIEIRAS & 96,83 & $100,00 \%$ \\
\hline 3 & CAJAMAR & 89,68 & $67,43 \%$ \\
\hline 4 & CARAPICUIBA & 16,64 & $48,92 \%$ \\
\hline 5 & COTIA & 261,47 & $80,52 \%$ \\
\hline 6 & EMBU & 56,99 & $81,01 \%$ \\
\hline 7 & FRANCO DA ROCHA & 41,92 & $31,44 \%$ \\
\hline 8 & ITAPECERICA DA SERRA & 142,46 & $94,51 \%$ \\
\hline 9 & ITAPEVI & 82,47 & $100,00 \%$ \\
\hline 10 & JANDIRA & 17,31 & $100,00 \%$ \\
\hline 11 & MAIRIPORÃ & 28,83 & $8,98 \%$ \\
\hline 12 & OSASCO & 6,23 & $9,58 \%$ \\
\hline 13 & SANTANA DE PARNAÍBA & 176,55 & $100,00 \%$ \\
\hline 14 & SAO LOURENCO DA SERRA & 10,88 & $5,82 \%$ \\
\hline 15 & SAO PAULO & 113,77 & $7,47 \%$ \\
\hline 16 & TABOAO DA SERRA & 1,82 & $8,98 \%$ \\
\hline 17 & VAR GEM GRANDE PAULISTA & 14,43 & $34,04 \%$ \\
\hline
\end{tabular}


TABELA 2: Informações sobre as rodovias estaduais e federais que atravessam a área de estudo (EMPLASA, 2006).

\begin{tabular}{|c|c|c|c|c|}
\hline NOME & DOMÍNII & PISTA & CLASSIFICACÃO & SITUAC $\tilde{A O}$ \\
\hline ESTR. DOS ROMEIROS & ESTADUAL & DUPLA & METROPOLITANO & PAVIMENTADA \\
\hline ROD. DOS BANDEIRANTES & ESTADUAL & DUPLA & MACROMETROPOLITANO & PAVIMENTADA \\
\hline ROD. PRES. CASTELO BRANCO & ESTADUAL & DUPLA & MACROMETROPOLITANO & PAVIMENTADA \\
\hline ROD. RAPOSO TAVARES & ESTADUAL & DUPLA & MACROMETROPOLITANO & PAVIMENTADA \\
\hline ROD. RÉGIS BITTENCOURT & FEDERAL & DUPLA & MACROMETROPOLITANO & PAVIMENTADA \\
\hline ROD. SP-023 & ESTADUAL & SIMPLES & METROPOLITANO & PAVIMENTADA \\
\hline ROD. SP-274 & ESTADUAL & SIMPLES & ESTRUTURAL URBANA & PAVIMENTADA \\
\hline RODOANEL MÁRIO COVAS & ESTADUAL & DUPLA & MACROMETROPOLITANO & PAVIMENTADA \\
\hline
\end{tabular}


No Mapa 2, constam também as estradas e rodovias estaduais e federais que atravessam a área de estudo. Dentre elas, oito receberam um destaque em função do fluxo de veículos, especialmente por serem vias federais e estaduais e, portanto, com maior volume de tráfego, além de atravessarem um maior número de cidades e estados. A seguir, estão algumas informações sobre as vias, como o nome, o domínio (se estadual ou federal), se a pista é dupla ou simples, a classificação e a situação da pavimentação. Essas informações foram obtidas em dados fornecidos pela EMPLASA (2006).

Devido à importância da presença dos grandes eixos rodoviários e ferroviários para a dinâmica do crescimento urbano na área estudada, realizamos um levantamento de informações relacionadas a essas vias, como: data de suas instalações, quais os municípios da área de estudo são atravessados por elas entre outros aspectos relevantes.

A rodovia mais antiga instalada na área é a SP 330 - Anhanguera: em 1914, foi construído o seu primeiro trecho e em 1940, o segundo. Ela atravessa, no trecho estudado, os municípios de São Paulo, Cajamar e Osasco. A rodovia mais recente que atravessa a área é a SP 021 - Rodoanel Mário Covas, uma rodovia de contorno da Região Metropolitana de São Paulo, destinada a interligar as rodovias de acesso a essa região. De acordo com a Dersa (2010), essa via vem sendo implantado por trechos: trecho oeste $(32 \mathrm{~km})$, já em operação desde 2002; trecho sul $(61 \mathrm{~km})$, em operação desde 2010; trecho leste obteve a licença prévia em 2010, com previsão de início de obras em 2011; trecho norte, ainda em fase de licenciamento ambiental, completará o anel rodoviário em torno da RMSP, devendo seccionar os municípios de São Paulo, Caieiras e Mairiporã. O oeste e o sul atravessam, no trecho estudado, os municípios de Itapecerica da Serra, Embu, Taboão da Serra, Cotia, Barueri e Santana de Parnaíba.

A Linha Férrea 8 Metropolitana (CPTM) exerce um papel fundamental para a conformação do tecido urbano da área estudada. Seu traçado é muito antigo e corresponde à antiga Estrada de Ferro Sorocabana, construída em 1870 para o transporte de carga, passando a operar, a partir de 1920, como transporte suburbano, atendendo ao transporte público intermunicipal. Na área estudada serve aos municípios de Itapevi, Jandira, Barueri e Carapicuíba.

As demais rodovias são: dos Bandeirantes - SP 348 (1978), Castello Branco - SP 280 (1968), Estrada dos Romeiros - SP 312 (sem data), Rodovia SP-274 (sem data), Rodovia Raposo Tavares-SP 270 (1937) e Regis Bittencourt BR -116 (1951). 
MAPA 02 - UNIDADES

ADMINISTRATIVAS E

SISTEMA VIÁRIO

Municípios Integrantes da Área de Estudo

\section{LEGENDA}

LIMITE DA AREA DE
ABRANGENCIA DO ESTUDO

:-... LIMITE RMSP

- SEDEs MUNICIPAIS

$\square$ LIMITES MUNICIPAIS

- RODOANEL MÁRIO COVAS

- RODOVIAS FEDERAIS E ESTADUAIS

_ SISTEMA VIÁRIO (RMSP)

FONTE DOS DADOS: INSTITUTO
FLORESTAL, IF, (2010); EMPLASA, (2006),

Projeção Universal Tranversal Mercator ( UTM) Elipsoide South American Datum (SAD) 1969 Organizaçăo e Elaboraçăo:
Júlia R. Leite, (2011).

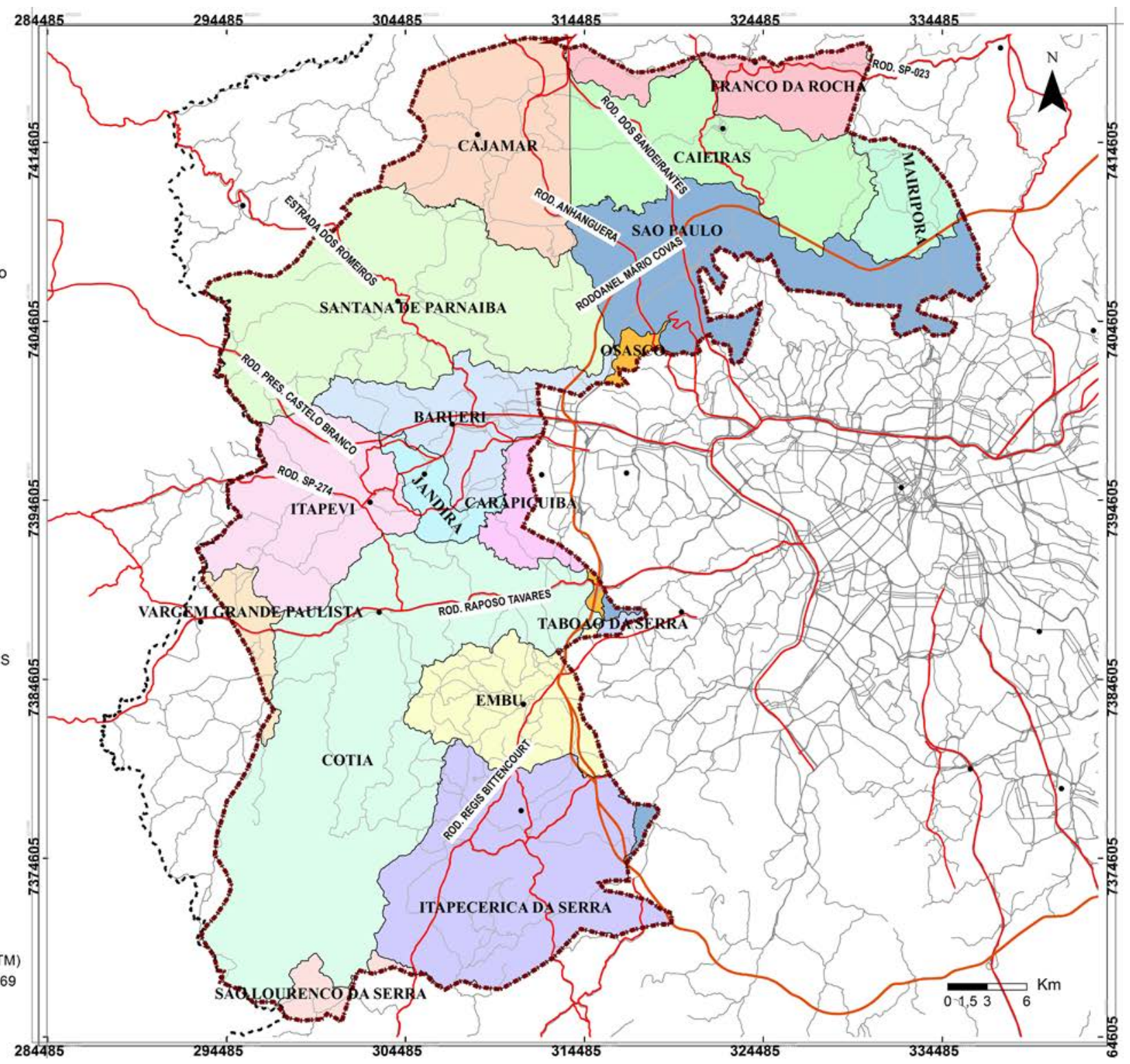




\subsubsection{USO DO SOLO}

Para produção do mapa do uso do solo, buscamos informações no mapeamento da EMPLASA (2006), realizado com shapefiles, que são polígonos georreferenciados que trazem dados relacionados às tipologias de uso do solo, definidas no mapeamento realizado sobre a imagem Ikonos de 2002.

Em nosso mapa, essas informações foram reinterpretadas, e as classes de vegetação Campo, Capoeira, Matas e Reflorestamento foram agrupadas em uma única categoria: Vegetação. Tais classes foram mais bem exploradas em um mapa destinado apenas a esse tema, denominado Vegetação e as Unidades de Conservação (Mapa 19), apresentado no próximo capítulo. Aqui, nos atemos à distribuição geral do uso do solo, evidenciando com maior detalhamento as demais classes, já que a vegetação será novamente tratada posteriormente.

Alterações foram feitas nas classes originais de Aterro Sanitário e Lixão, embora sejam bem distintas - a primeira é o destino final correto dos resíduos e a segunda refere-se à degradação e ao abrigo dos resíduos sem cuidados, que exige remediação; entretanto, na escala avaliada, essa distinção não foi considerada e ambas as classes foram agrupadas para facilitar a interpretação do uso do solo. O mesmo foi feito para as classes de Loteamentos Desocupados e Solo Exposto.

O Mapa 3 ilustra a discussão seguir.

Da área total estudada, com aproximadamente $1.216 \mathrm{~km}^{2}$, a classe predominante no mapa do uso do solo se refere à Vegetação, com $70,88 \%$ do total. Já a área urbanizada aparece como a segunda de maior predominância, com $11,71 \%$, e em seguida, os usos por chácaras e hortifrutigranjeiros, com 9,47\%. O Solo Exposto e o Loteamento Desocupado aparecem com $1,63 \%$ da área total. As demais classes de uso do solo ocupam menos de 1\%, ou seja, os percentuais não são muito significativos, mas como a área estudada possui grande dimensão, essa presença não deixa de ter importância. As classes mapeadas, suas respectivas áreas de abrangência e os percentuais relativos à área total de estudo são apresentados na Tabela 3 a seguir.

Importante retomar que o fato de haver um predomínio de vegetação, comprovado pela avaliação realizada, na borda urbana da RMSP, foi um dos critérios para a seleção da área de estudo. A relevância dessa situação de ocupação do território para discussão da possibilidade de proposição de um sistema de corredores ecológicos constitui-se como um elemento facilitador na visão conservacionista, preservacionista e de recomposição dos elementos naturais ainda presentes no trecho. 
MAPA 3 - USO DO SOLO

LEGENDA

LaRANGENCIA DO ESTUDO

- HIDROGRAFIA PRINCIPAL

- SEDES MUNICIPAIS NA ÁREA

HWH FERROVIAS

- RODOVIAS

USO DO SOLO

AREA URBANIZADA

HABITAÇÕES PRECÁRIAS

INDÚSTRIA

MINERAÇÃ̃o

CHACARAS

ATERRO SANITARIO E LIXÃO

SOLO EXPOSTO

VEGETAÇÃO

VEGETAÇÃo DE VARZEA

ESPELHO DAGUA

RESERVATORIO DE RETENCAO

OUTROS USOS

FONTE DE DADOS: EMPLASA, 2006.

Projeçăo Universal Tranversal

Mercator ( UTM) Fuso 23

Elipsoide South American Datum ( SAD) 1969

Organizaçăodos dados e Elaboraçăo:

Júlia R. Leite, (2011)

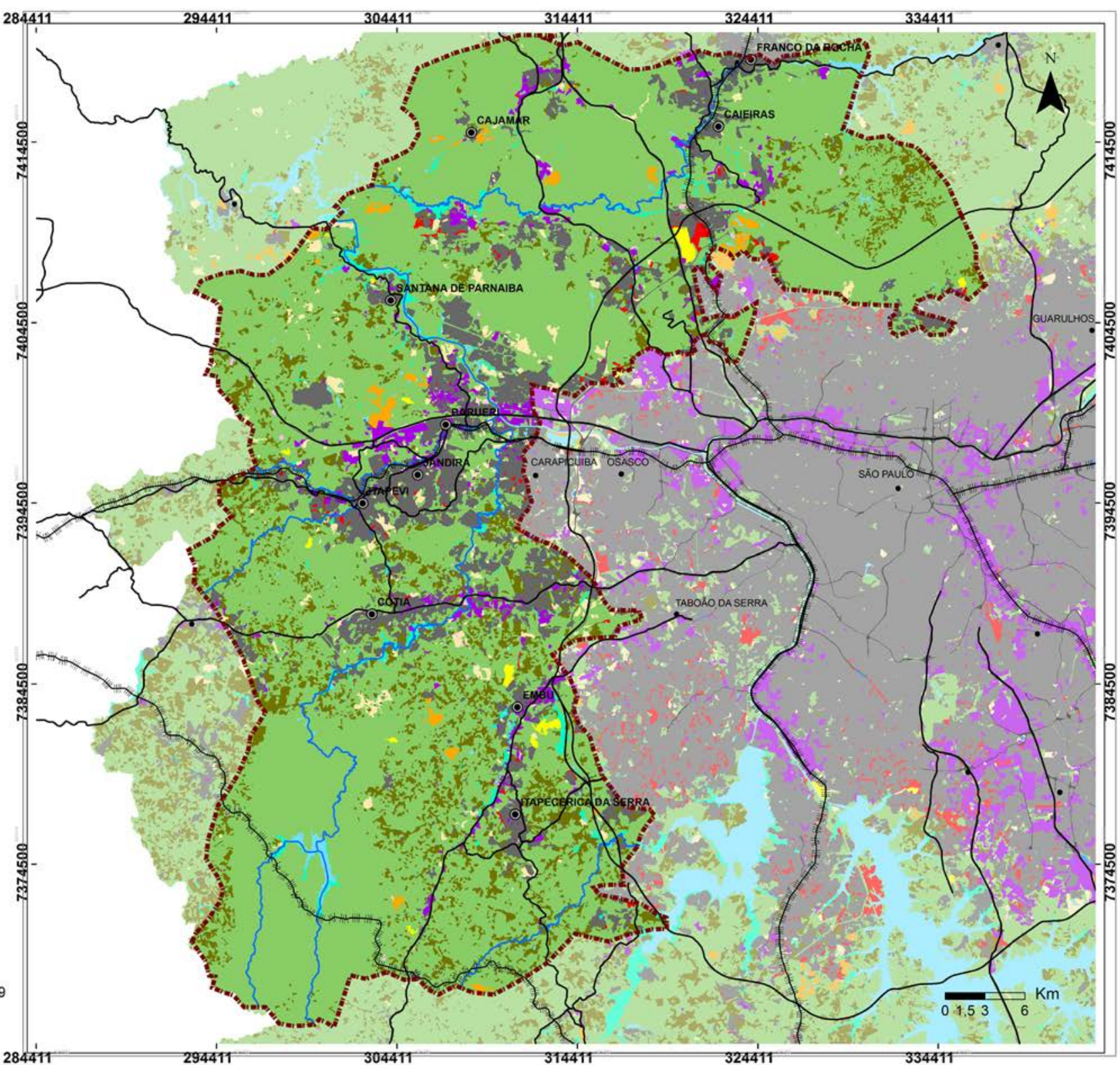


TABELA 3: Classes de uso do solo encontradas na área de abrangência de estudo, suas áreas e percentuais da área total.

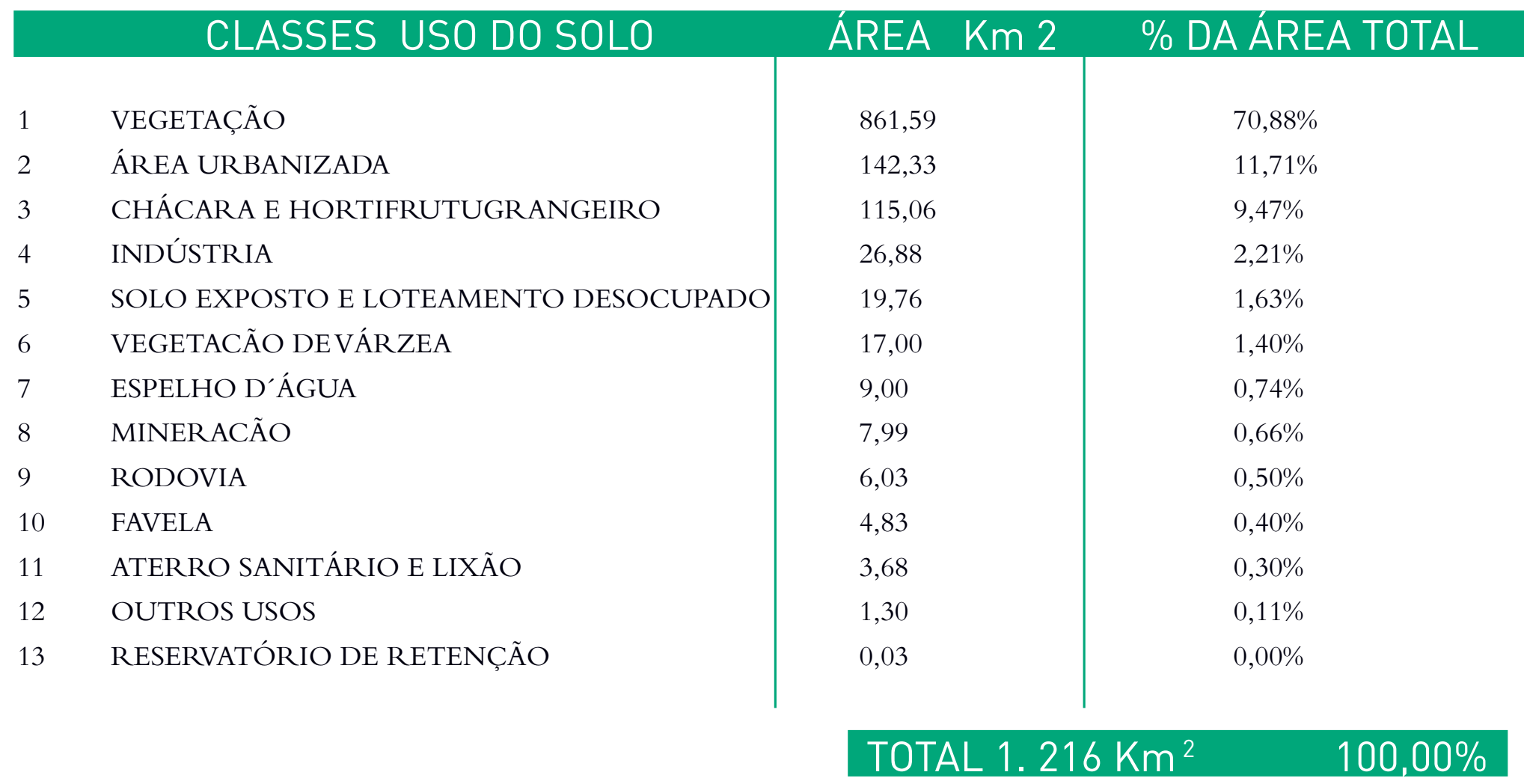




\subsection{4 ÁREAS DE CONSERVAC̣ÃO E PRESERVAC̣̃̃O}

Examinamos os planos diretores dos municípios envolvidos no setor oeste da $\mathrm{RBCV}^{33}$, buscando, no âmbito da legislação municipal, as macrozonas ecológicas, áreas de conservação, preservação, as zonas de restrição à ocupação, de maneira a correlacionarmos essas informações às regiões com valor ecológico da área estudada.

O plano diretor municipal é um instrumento de desenvolvimento urbano previsto no Estatuto da Cidade, que corresponde à denominação oficial da Lei Federal 10.257, de 10 de Julho de 2001. Permite que os municípios definam o padrão de ocupação urbana de seus territórios, por meio da proposição de macrozonas, zonas e diretrizes, e assim direcionem o crescimento urbano às áreas que tenham capacidade para determinados usos, de maneira a equacionar todos os interesses municipais com as limitações e condicionantes ambientais. Visa, ainda, à racionalização do uso de recursos públicos para a melhoria da qualidade de vida da população e preservação dos recursos naturais.

Solicitamos às secretarias responsáveis pelo planejamento urbano dos municípios os mapas relacionados ao tema estudado ${ }^{34}$. De posse desse material, em diversos formatos (PDFs, Imagens JPGs, arquivos DWGs), realizamos o georreferenciamento em formato shapefile, para adicionar à base de dados. Os polígonos produzidos foram adicionados ao Mapa de Vegetação junto com as informações obtidas anteriormente sobre unidades de proteção ambiental. As informações sobre as áreas mapeadas foram organizados no Quadro 3 a seguir.
${ }^{33}$ Esta atividade da pesquisa foi desenvolvida em parceria com o Comitê Gestor do Instituto Florestal da RBCV.

${ }^{34}$ Com exceção dos municípios Itapevi, São Lourenço da Serra e Osasco, os quais receberam a solicitação para envio de material de seus planos diretores e não responderam. 
Todos os municípios estudados possuem zonas e macrozonas de proteção e conservação ambiental. Os limites das áreas que guardam recursos naturais significativos, sendo, portanto, protegidas pelo município, são explicitados por meio de diretrizes gerais nos planos diretores e respectivos mapas com zoneamento territorial. Importante realçar que a maior parte dos limites definidos também é passível de ser alterada e revista por medidas municipais, de acordo com interesses e necessidades do poder público. Por esse motivo, incluir tal discussão na pesquisa foi importante para que os esforços possam ser incorporados no sistema de corredores mas também para que o presente estudo possa fomentar, subsidiar e apoiar as discussões acerca dessas áreas com valor ecológico, dentro do âmbito municipal.

Alguns municípios, como Santana de Parnaíba e Embu das Artes, possuem em seu plano diretor áreas mais bem regulamentadas do ponto de vista ambiental, como a APA Embu Mirim, prevista, mas ainda sem seu plano de manejo - condição para se tornar uma Área de Proteção Ambiental oficial, e também o Parque daVárzea do Rio Embu Mirim, ainda em obras, que também sediará um novo campus da Universidade Federal Paulista (UNIFESP). Em Santana de Parnaíba estão previstas áreas de proteção à APA Várzea Tietê, do Morro Tuvurussum, Serra Itaqui, futuro Parque Burle Marx e Lagoa Bacuri, bem como a área natural tombada pelo CONDEPHAT, o Morro do Boturuna e a Reserva Biológica Tamboré , área municipal de 3,68 $\mathrm{Km}^{2}$ onde foi instituída uma Unidade de Conservação Ambiental (UCA), administrada por uma organização não governamental. O Quadro 3 a seguir contém um resumo das áreas incluídas no estudo. 
QUADRO 3:Áreas de conservação e preservação municipais identificadas nos municípios, dentro da Área de Abrangência do Estudo.

\section{MUNICIPIOS ÁREAS DE CONSERVACÃO E PRESERVACÃO MUNICIPAIS}

BARUERI

-ZPA 1 - Zona de Proteção Ambiental a Qualificar

-ZPA 2 - Zona de Proteção Ambiental a Preservar

-Bioma da Mata Atlântica (parte Oeste do Município)

CAJAMAR $\quad$ APA Cajamar

\begin{tabular}{ll}
\hline CARAPICUIBA & Área de Urbanização Controlada \\
& $\bullet$ Área de Proteção e Urbanização Controlada \\
\hline & \\
COTIA & ZPA - Zona de Preservação Ambiental \\
& $\bullet$ Reserva Florestal do Morro Grande \\
& - Parque das Nascentes \\
& $\bullet$ Parque Tizo \\
& $\bullet$ Cemucam
\end{tabular}

EMBU

-Áreas de Proteção Ambiental

-Parque da Várzea do Rio Embu Mirim

-ZEIA - Zona Especial de Interesse Ambiental

-ZDR - Zonal de Desenvolvimento Rural Urbano

-APA Embu Verde

-Fonte de Água Mineral dos Jesuítas 


\begin{tabular}{|c|c|}
\hline ITAPECERICA DA SERRA & $\begin{array}{l}\text {-Macrozona de Preservação } \\
\text {-ZEPA - Zona Especial de Proteção Ambiental - Parque da Várzea do Embu Mirim }\end{array}$ \\
\hline JANDIRA & $\begin{array}{l}\text {-ZEIA } 1 \text { - Zona Especial de Interesse Ambiental - Área de Lazer - Cidade da Família } \\
\text {-ZEIA } 2 \text { - Zona Especial de Interesse Ambiental - Várzea Rio São João } \\
\text {-ZEIA } 3 \text { - Zona Especial de Interesse Ambiental - Sitio Pedra Bonita/Pq Natural } \\
\text { Municipal Portal Ecológico } \\
\text {-ZEIA } 4 \text { - Zona Especial de Interesse Ambiental - Pedreira do Mirante } \\
\text {-ZERA - Zona Especial de Recuperação Ambiental /Antigo Lixão }\end{array}$ \\
\hline MAIRIPORÃ & $\begin{array}{l}\text { - Reserva Estadual da Cantareira } \\
\text { - Zona de Uso Sustentável/Macrozona de Preservação }\end{array}$ \\
\hline SANTANA DO PARNAIBA & $\begin{array}{l}\text {-APA Várzea Tiete } \\
\text { - Morro Tuvurussu } \\
\text { - Morro Tuvurussu } 2 \\
\text {-Serra Itaqui } \\
\text { - Futuro Parque Burle Marx } \\
\text { - Lagoa Bacuri } \\
\text { - Área Natural Tombada Morro do Boturuna } \\
\text { - Reserva Biológica Tamboré }\end{array}$ \\
\hline SÃO PAULO & $\begin{array}{l}\text {-Zona Especial de Proteção Ambiental; } \\
\text {-Parques e Reservas Existentes: } \\
\text {-Parque Jaraguá } \\
\text {-Parque Anhanguera } \\
\text { - Reserva Cantareira } \\
\text {-Zona Especial de Proteção Agrícola e Extração Mineral. }\end{array}$ \\
\hline TABOÃO DA SERRA & $\begin{array}{l}\text {-Área Homogênea de Proteção Ambiental } \\
\text {-Parque Proposto } \\
\text {-Área Privada com Vegetação Significativa }\end{array}$ \\
\hline VARGEM GRANDE PAULISTA & $\begin{array}{l}\text {-Área de Proteção Ambiental } 1 \\
\text { - Área de Proteção Ambiental } 2\end{array}$ \\
\hline
\end{tabular}




\subsubsection{AVALIAC̣ÃO TEMPORAL DO CRESCIMENTO DA MANCHA URBANA}

Diante da intensa pressão de desenvolvimento que alguns trechos mais urbanizados realizam sobre as áreas ainda não urbanizadas, sejam as últimas cobertas com matas nativas secundárias de vegetação ombrófila densa, capoeira, campo, reflorestamento ou até mesmo com solo exposto, consideramos importante, para avançar numa proposta de implantação de corredores ecológicos, a realização de um estudo temporal.

A idéia foi avaliar o padrão de crescimento urbano na área de abrangência do estudo ao longo das três últimas décadas, iniciando-se na de 70, pela disponibilidade de imagens de satélite,

TABELA 4: Análise temporal do uso do solo.

\begin{tabular}{|c|c|c|c|c|c|c|c|c|}
\hline \multirow[b]{2}{*}{ CLASSE } & \multicolumn{2}{|c|}{$1975^{\star}$} & \multicolumn{2}{|c|}{1986} & \multicolumn{2}{|c|}{1995} & \multicolumn{2}{|c|}{2010} \\
\hline & $\mathrm{Km}^{2}$ & $\%$ & $\mathrm{Km}^{2}$ & $\%$ & $\mathrm{Km}^{2}$ & $\%$ & $\mathrm{Km}^{2}$ & $\%$ \\
\hline ÁGUA & 14,28 & 1,2 & 17,32 & 1,4 & 11,01 & 0,9 & 8,34 & 0,7 \\
\hline ÁREA URBANA & 115,9 & 9,5 & 90,83 & 7,5 & 126,10 & 10,4 & 145,27 & 11,9 \\
\hline $\begin{array}{l}\text { CAMPO/ } \\
\text { CAPOEIRA }\end{array}$ & 426,8 & 35,1 & 435,39 & 35,8 & 330,52 & 27,2 & 466,74 & 38,4 \\
\hline MATA TOTAL & 642,35 & 52,8 & 513,35 & 42,1 & 544,76 & 44,7 & 443,38 & 36,5 \\
\hline REFLOREST & - & - & 115,09 & 9,5 & 167,43 & 13,8 & 102,26 & 8,4 \\
\hline S/ DADOTOTAL & - & - & 2,08 & 0,2 & - & 0,0 & 0 & 0,0 \\
\hline SOLOEXPOSTO & 16,98 & 1,4 & 42,25 & 3,5 & 36,50 & 3,0 & 50,32 & 4,1 \\
\hline TOTAL & $1.216,31$ & $100 \%$ & $1.216,31$ & $100 \%$ & $1.216,31$ & $100 \%$ & $1.216,31$ & $100 \%$ \\
\hline
\end{tabular}

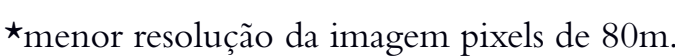


mas também porque, nessa ocasião, a população urbana do Brasil superou a rural (MEYER e GROINSTEIN, 2004).

Buscamos realizar então uma análise temporal do crescimento urbano e, consequentemente, da supressão da vegetação na área estudada por meio de análises de imagens de satélite em quatro momentos: 1975, a mais antiga; 1986, 1995 anos intermediários, e 2010, a mais recente. O momento de implantação das rodovias foi um dado que norteou a definição dos anos a serem pesquisados, mas a disponibilidade de imagens gratuitas de satélite foi determinante como fator de escolha para o primeiro ano de avaliação, 1975.

A partir dos estudos desenvolvidos, obtivemos alguns resultados importantes. O primeiro deles foi o mapeamento do uso do solo nos quatro momentos.

A Figura 12 a seguir traz um quadro-síntese contendo as quatro imagens interpretadas. A Tabela 4 e os Gráficos 1 e 2 mostram as áreas de cada classe de uso encontrada em $\mathrm{km}^{2}$ e o percentual que esta representa da área total, expressando o índice de crescimento absoluto de cada classe de uso do solo ao longo do tempo. O Gráfico 1 contém a representação das alterações absolutas sofridas em cada classe de uso estudada para cada período. O Gráfico 2 possui barras que representam a soma das áreas de cada classe de uso do solo dentro da área total de estudo, sendo possível visualizar o percentual de crescimento absoluto e relacioná-lo ao aumento relativo em cada classe e respectivos anos.

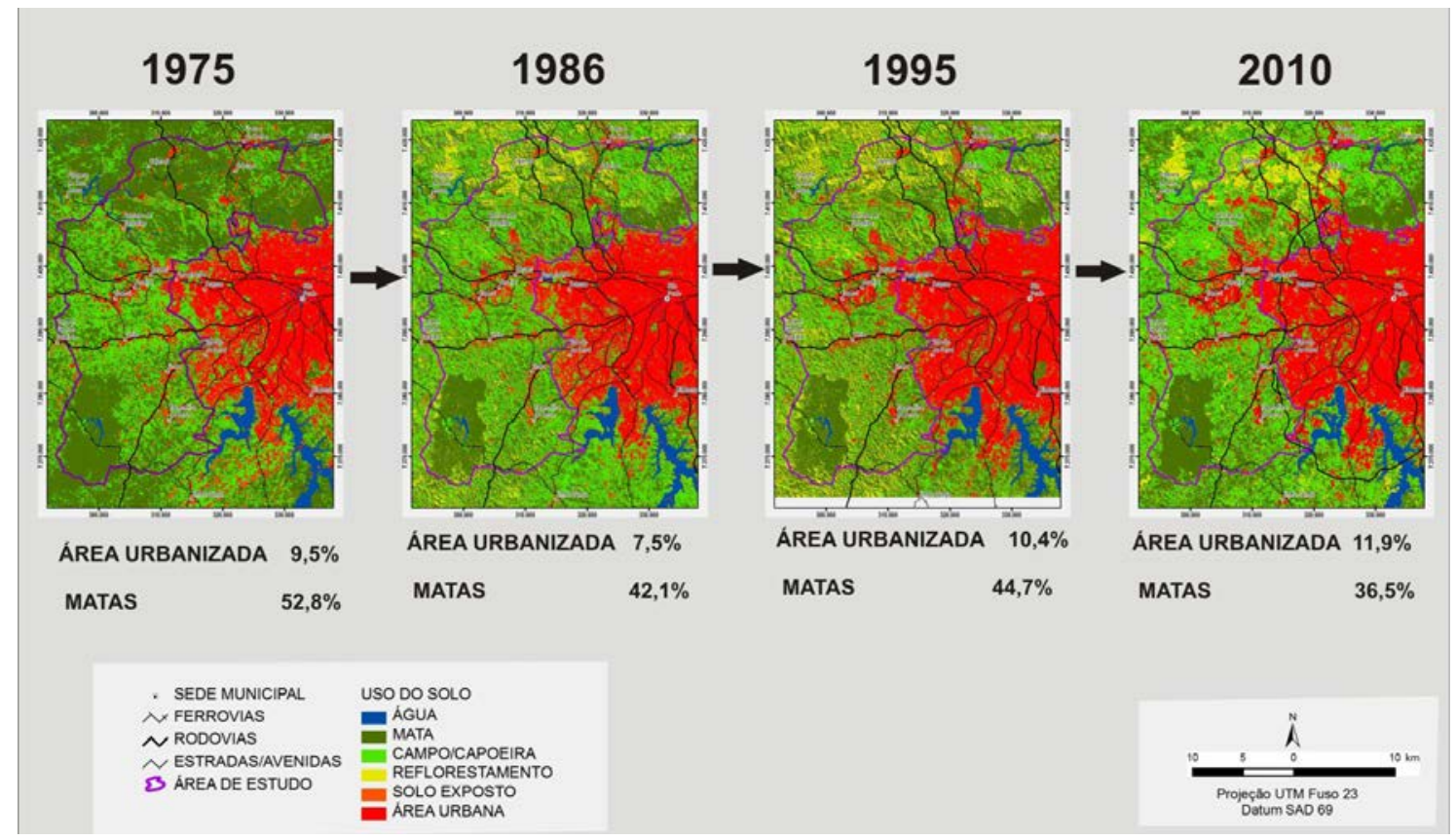

FIGURA 12: Avaliação temporal do crescimento urbano. Base: Satélite Landsat 5 nas datas: 27/05/1975; 19/06/1986;28/06/1995;04/05/2011. 
GRÁFICO 1 - Análise temporal das classes de uso do solo.

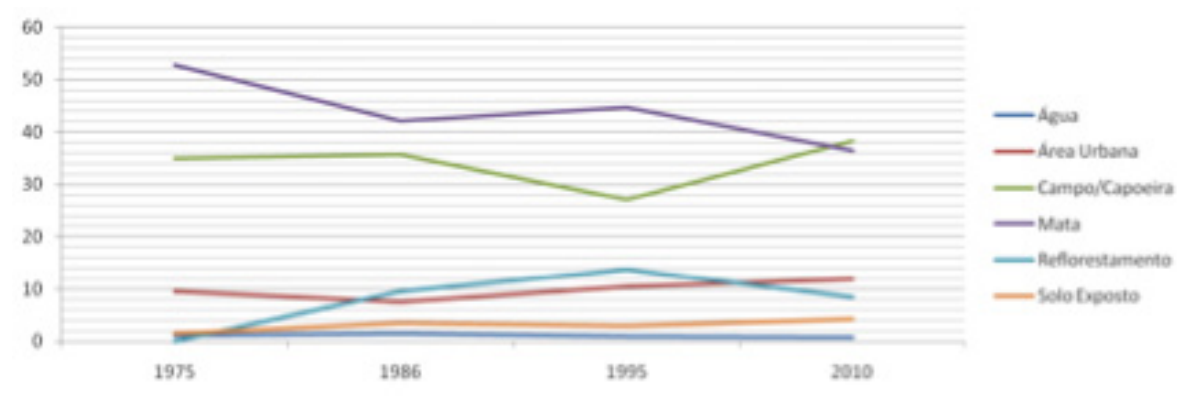

GRÁFICO 2 - Histograma da análise temporal das classes de uso do solo.

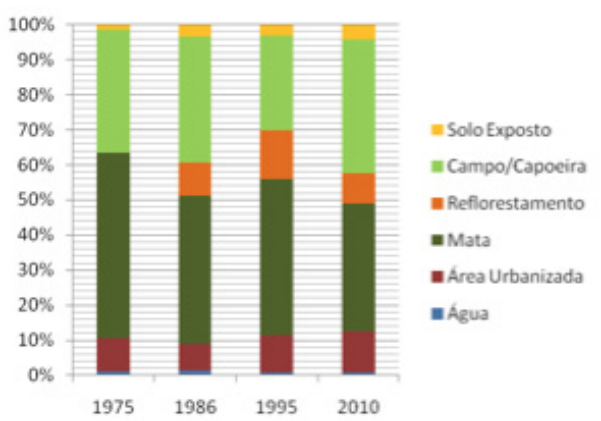

A Tabela 5 e o Gráfico 3, apresentados a seguir, contêm o porcentual relativo de crescimento e de regressão das áreas das classes de uso do solo estudadas, em relação ao número da área inicial de cada classe. Como pode ser visualizado, um crescimento urbano como o que ocorreu entre 1986 e 1995, no valor de 2,9 pontos percentuais, conforme Tabela 5, representou um aumento de área urbanizada de 39\% em relação à data anterior (nove anos).

GRÁFICO 3 - Crescimento relativo em percentuais (\%) de cada classe de uso do solo.

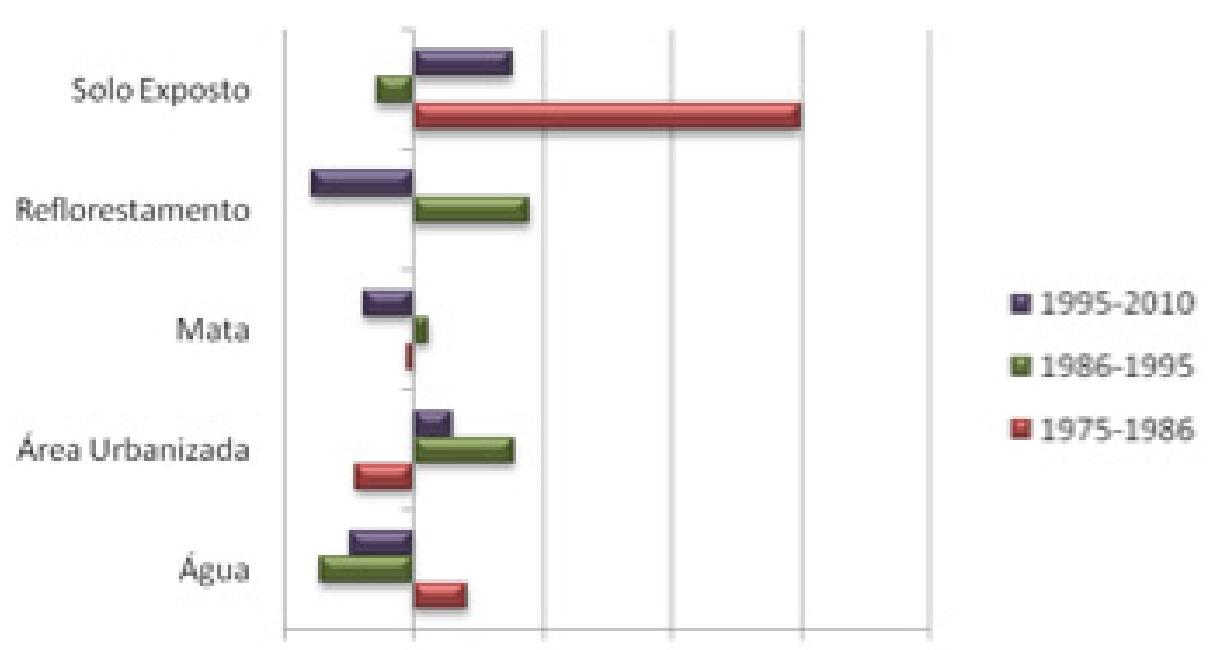


TABELA 5 - Variação histórica das classes do uso do solo.

\begin{tabular}{|c|c|c|c|c|c|c|c|}
\hline \multirow[b]{2}{*}{ CLASSE } & \multicolumn{2}{|c|}{1975} & \multicolumn{2}{|c|}{1986} & \multicolumn{2}{|c|}{1995} & \multirow{2}{*}{$\begin{array}{l}2010 \\
\mathrm{Km}^{2}\end{array}$} \\
\hline & $\mathrm{Km}^{2}$ & IAR \% & $\mathrm{Km}^{2}$ & IAR \% & $\mathrm{Km}^{2}$ & IAR \% & \\
\hline Água & 14,28 & 21 & 17,32 & -36 & 11,00 & -24 & 8,34 \\
\hline Área urbana & 115,90 & -22 & 90,83 & 39 & 126,10 & 15 & 145,27 \\
\hline Campo/capoeira & 426,80 & 2 & 435,38 & -24 & 330,52 & 41 & 466,74 \\
\hline Mata & 642,35 & -2 & $513,35^{\star}$ & 6 & 544,76 & -19 & 443,38 \\
\hline Reflorestamento & - & - & 115,09 & 45 & 167,43 & -39 & 102,26 \\
\hline S/dado & - & - & 2,08 & - & - & - & - \\
\hline Solo exposto & 16,98 & 149 & 42,25 & -14 & 33,50 & 38 & 50,32 \\
\hline
\end{tabular}

IAR -Índice de Alteração Relativo à data anterior

* Os valores das áreas de Mata e Reflorestamento foram somados para cálculo da alteração sofrida na data anterior. 


\section{MAPA 4 - USO DO SOLO 1975}

Avaliação Temporal do Crescimento Urbano

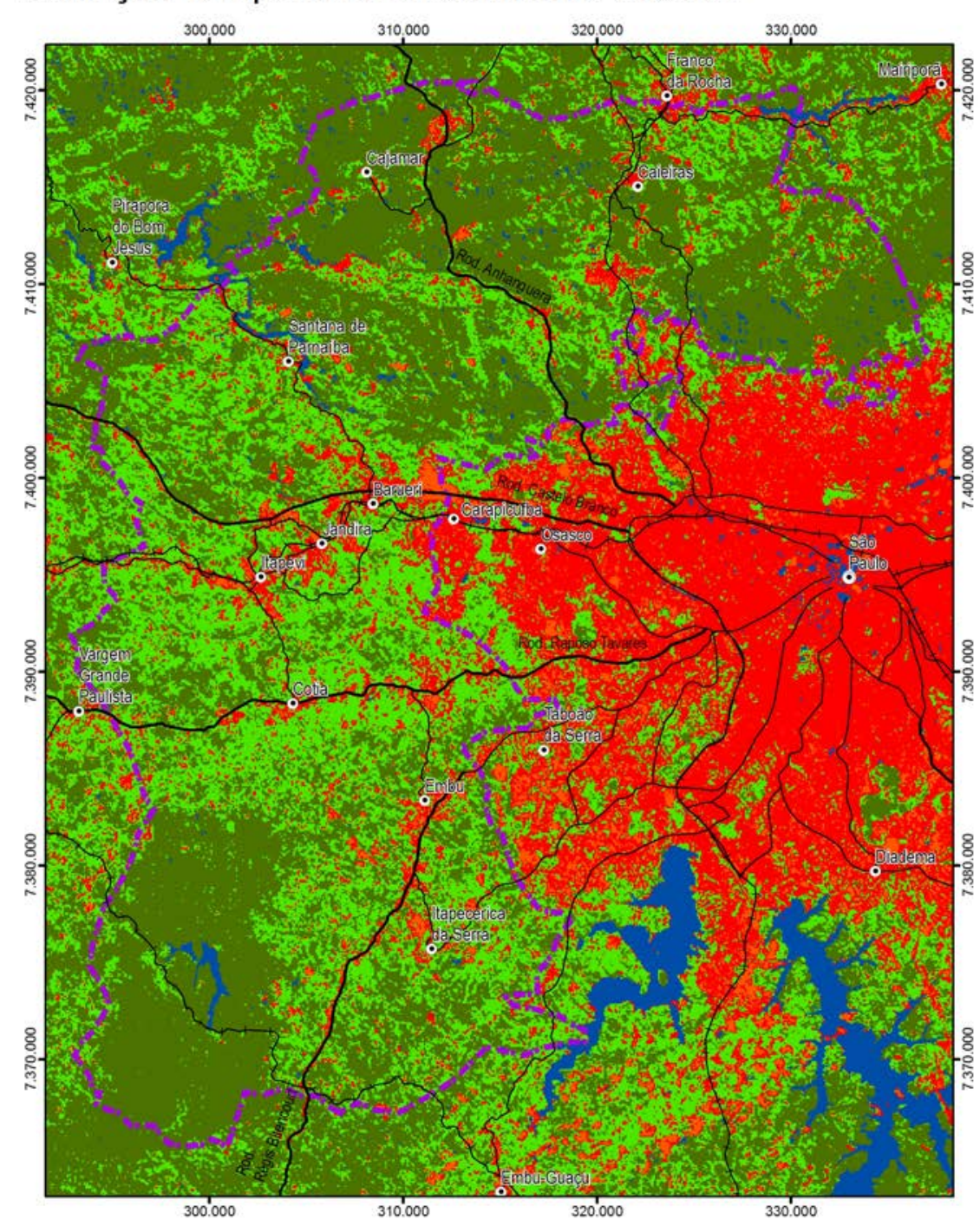

Mapa elaborado por classificação supervisionada a partir da imagem do satélite LandSat 5 de 27/05/1975
- SEDE MUNICIPAL
USO DO SOLO
$\triangle \times$ FERROVIAS
$\sim$ RODOVIAS
MATA E REFLORESTAMENTO
CAMTRADASAVENIDAS CAMPOEIRA
12. AREADE ESTUDO
SOLO EXPOSTO

\begin{tabular}{c} 
Escala: 1:300.000 \\
$5.5 \quad 0$ \\
\hline
\end{tabular}

Projeção UTM Fuso 23 
MAPA 5 - USO DO SOLO 1986

Avaliação Temporal do Crescimento Urbano

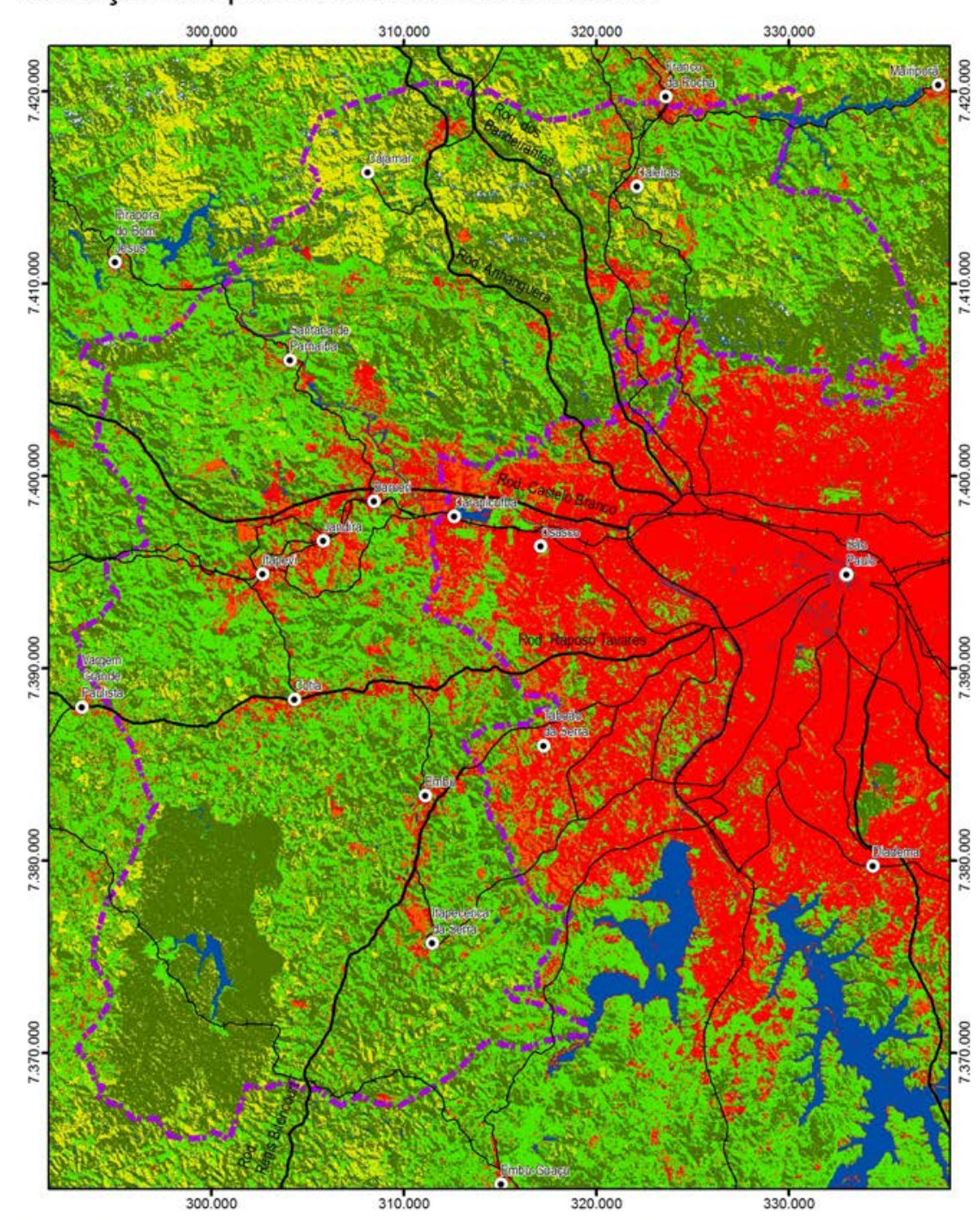

Mapa elaborado por classificação supervisionada a partir da imagem do satélite LandSat 5 de 19/06/1986
- SEDE MUNICIPAL
USO DO SOLO
$\leadsto \times$ FERROVIAS
ÁGUA
A
$\sim$ RODOVIAS
E. ERTRADAS/AVENIDA
- MATA
REFLORESTAMENTO
- SOLO EXPOSTO
Escala: $1: 300.000$
2.5
0
Projeção UTM Fuso 23
Datum SAD 69 
MAPA 6 - USO DO SOLO 1995

Avaliação Temporal do Crescimento Urbano

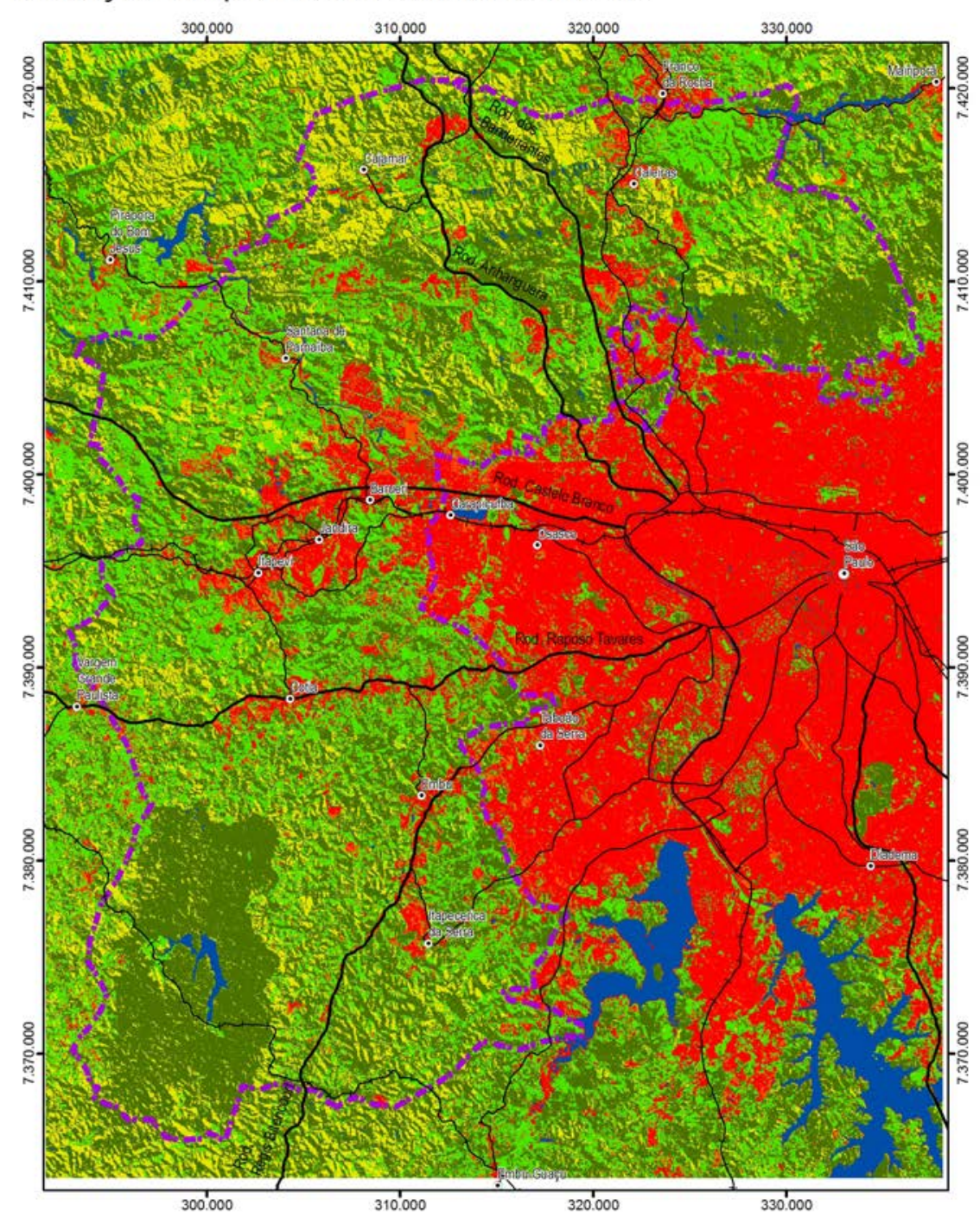

Mapa elaborado por classificação supervisionada a partir da imagem do satélite LandSat 5 de 28/06/1995

- SEDE MUNICIPAL USO DO SOLO

- SEDE MUNICIPAL

USO DO SOLO
ÁGUA

$\sim$ RODOVIAS

MATA

A

NESTRADAS/AVENIDAS

2. ÁREA DE ESTUDO

- MATA

REFLORESTAMENTO

- SOLO EXPOSTO

Escala: $1: 300.000$
$2.50^{5}$
Projeção UTM Fuso 23

ÁREA URBANA 
MAPA 7 - USO DO SOLO 2010

Avaliação Temporal do Crescimento Urbano

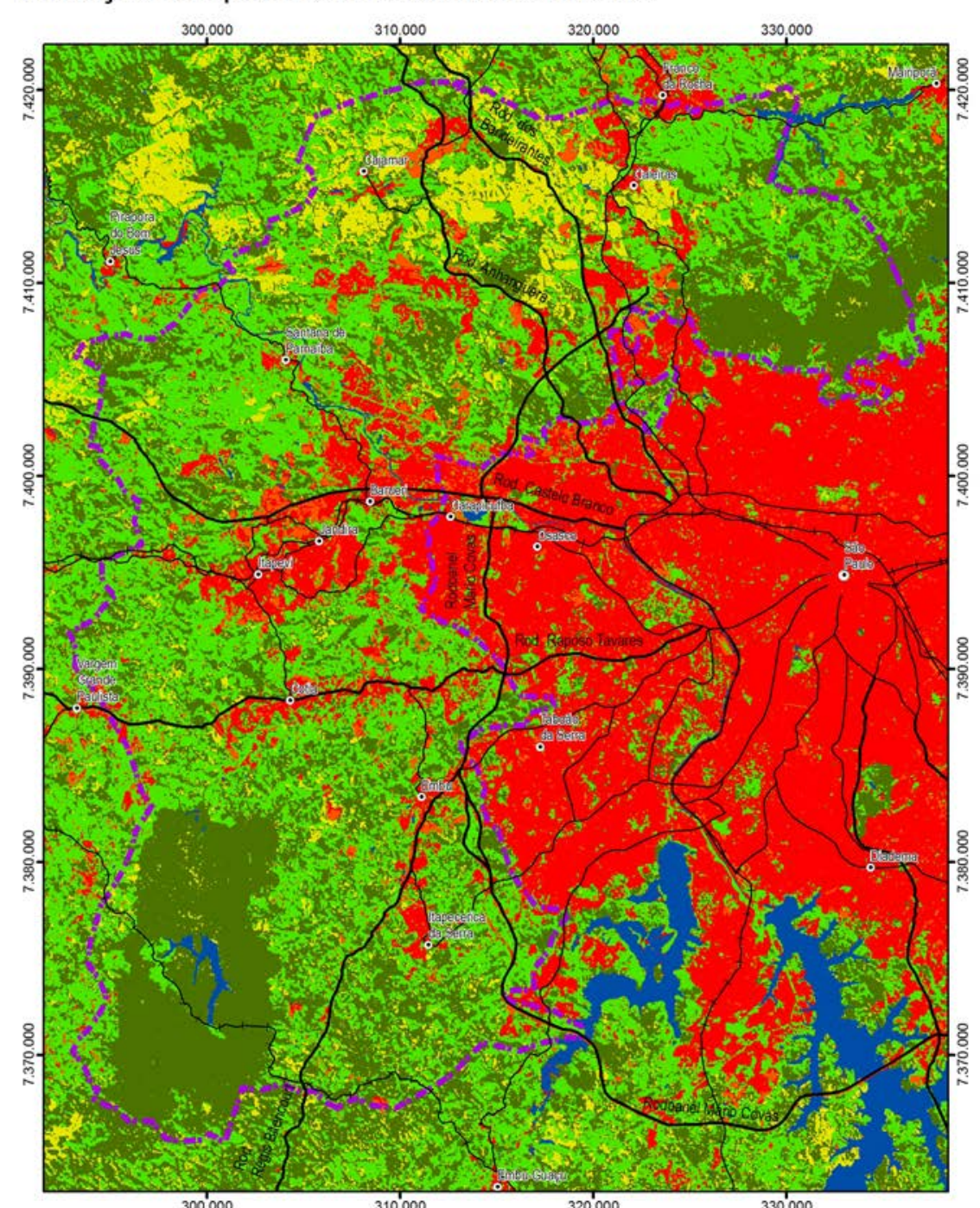

Mapa elaborado por classificação supervisionada a partir da imagem do satelite LandSat 5 de 04/05/2010
- SEDE MUNICIPAL
$\rtimes \times$ FERROVIAS
USO DO SOLO
$\sim$ RODOVIAS
- AGUA
ESTRADAS/AVENIDAS
MATA
1. ÁREADE ESTUDO
CAMPO/CAPOEIRA
SOLO EXPOSTO

$\bigwedge^{N}$

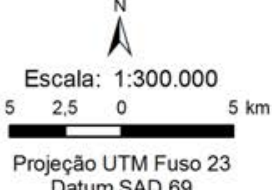

Projeção UTM Fuso 23
Datum SAD 69 
Como a imagem de 1975 possui tamanhos de pixels maiores que as demais, os resultados apresentaram algumas incongruências, não sendo possível diferenciar a classe de Mata e Reflorestamento com precisão. Dessa forma, a avaliação numérica da supressão de matas só pôde ser feita para os anos de 1986, 1995 e 2010, identificando-se, assim, que em 24 anos houve a perda da ordem de 7.000 hectares de matas, o que configura o desmatamento ocorrido na área. Se somarmos, em todas os quatro anos estudados, os valores das áreas de Mata e Reflorestamento conjuntamente, podemos identificar que em 35 anos ocorreu a remoção de vegetação de porte arbóreo num total de 96,73 $\mathrm{km}^{2}$. Entretanto, os reflorestamentos são áreas comerciais; portanto, um plantio realizado com o objetivo de produção é passível de corte. A soma da supressão da vegetação de porte arbóreo do reflorestamento com as matas é um dado que trata parcialmente do desmatamento ilegal.

A remoção de Pinus sp., por exemplo, muitas vezes, é fundamental para o desenvolvimento das matas, pois essa espécie atua como inibidora biológica, o que atrapalha bastante o crescimento de outras espécies arbóreas nativas. A remoção de Eucaliptus sp. tem também suas vantagens, pois supre a necessidade de madeira e serve como uma alternativa à proibição de corte de árvores nativas. Assim, não podemos chamar de desmatamento essas supressões, aqui consideradas em conjunto.

De modo geral, com relação aos locais de supressão de vegetação arbórea dentro da área de estudo, observando as imagens, podemos afirmar que grande parte dos fragmentos com vegetação de porte arbóreo, inicialmente identificados nas imagens de 1975, e depois em 1986 e 1995, sofreu redução em suas áreas. O desmatamento nesse período, de modo geral, foi difuso; os fragmentos foram sendo suprimidos pelas suas bordas, tornando suas áreas cada vez menores ao longo dos anos avaliados. Houve pontos em que observamos uma maior concentração de supressão da vegetação, como pode ser visualizado no Mapa 8 a seguir, indicando que, em alguns trechos, foi mais intensa, dando em geral lugar a áreas urbanizadas.

Os dois maiores focos de supressão de vegetação estão localizados na parte norte do trecho estudado e indicam que o corte de árvores e aumento da fragmentação são processos mais antigos do que na parte sul, tendo maior repercussão e diminuição da vegetação. Nas partes central e sul do trecho estudado, identificamos visualmente outros pontos de supressão mais concentrada, mas que se confundem muito com o processo de supressão difusa claramente identificado na primeira observação. 
MAPA 8 - SUPRESSÃO DA VEGETAÇAO EM 35 ANOS Interpretação Ecológica da Paisagem

\section{LEGENDA}

LIMITE DA ÁREA DE
ABRANGÊNCIA DO ESTUDO

REDE HIDRICA RBCV

PONTOS DE MAIOR CONCENTRAÇÃO DE SUPRESSÃO DA
PORTE ARBOREO

\section{VEGETAÇÃo 2010 \\ MATA \\ REFLORESTAMENTO}

VEGETAÇÃO 1995

MATA

REFLORESTAMENTO

\section{VEGETAÇÃO 1986}

MATA

REFLORESTAMENTO

\section{VEGETAÇÃO 1975}

MATAE REFLORESTAMENTO

FONTE: MAPA ELABORADO POR CLASSIFICAÇÃO SUPERUSANADA DE MAGEM DOSATELITE 28/06/1995: 19/06/1986: 27/05/1975

Projeção Universal Tranversa

Elipsoiide South American Datum ( SAD) 1969 Elaboraçăo: Júlia R. Leite, (2011).

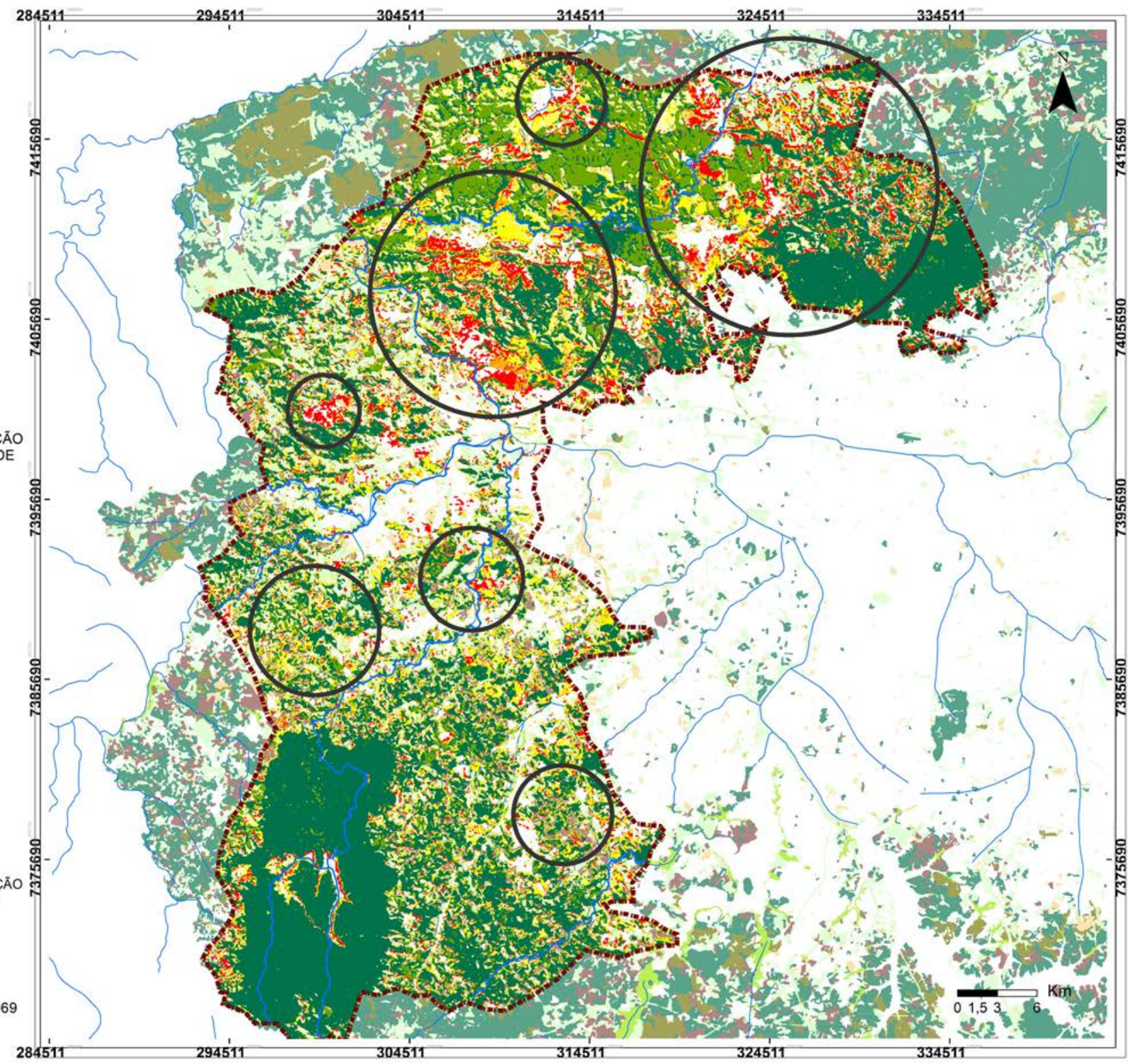


No mapa anterior, há indicação de desmatamento na Reserva do Morro Grande, o que não aconteceu. Trata-se da instalação de algum equipamento da Sabesp e da presença de água no reservatório que não foram identificados automaticamente pelo processo de mapeamento empregado.

Entre 1986 e 1995, houve aumento de 6\% e 45\% das classes Matas e Reflorestamento, respectivamente, e a diminuição das áreas de Solo Exposto e Campo/Capoeira, em 14\% e 24\%, respectivamente. Isso pode ser explicado por uma prática de reflorestamento de plantio de Eucaliptos e Pinus, para silvicultura, que deve ter sido empreendida em terras com Campo/Capoeira e Solo Exposto. Já o crescimento de mata pode ter sido uma decorrência espontânea dos bosques de Reflorestamento, que, em alguns casos, conseguem estimular o crescimento de matas por funcionarem como vegetação pioneira e estimularem o crescimento e sucessão de sub-bosque vegetal ou de vegetação espontânea. Pode ter ocorrido também algum plantio de árvores nativas que se desenvolveram sobre as áreas permeáveis, mas é importante frisar que, na década em questão, a prática recorrente de reflorestamento era o plantio das exóticas Eucalyptos sp e Pinus sp.

Por outro lado, ainda analisando esse mesmo período, observamos um crescimento de áreas urbanizadas de 39\%, índice que corresponde a um desenvolvimento urbano significativo em uma década e que pode estar relacionado a assoreamento de rios, ocupação de margens e várzeas por áreas urbanas (implantação de loteamentos, prédios, vias de transportes, dentre outros).

Porém, a diminuição de áreas urbanas no primeiro período analisado não corresponde a um dado claro, e não encontramos explicações que a justifiquem. Podemos atribuí-la a limitações da metodologia relacionadas à diferença de tamanho de pixels da imagem de 1975, e por esse motivo descartamos essa informação relacionada às áreas urbanas. Como pode ser visualizado nas Tabelas 4 e 5, a urbanização aparece como uma constante crescente ao longo dos quatorze anos.

Houve um crescimento das áreas urbanizadas de 54\% durante 24 anos, de caráter concentrado, quase que exclusivamente nas áreas marcadas na Figura 13 a seguir. Isso ocorreu em função das facilidades e infraestruturas criadas pelas rodovias, pela linha de trem metropolitano da CPTM, por empreendimentos imobiliários, como condomínios e loteamentos de alto e médio padrão, e também alguns locais para habitações populares. O pólo mais significativo de crescimento urbano aconteceu entre os municípios de Barueri, Itapevi, Jandira e Santana do Parnaíba. Em Cotia e Carapicuíba, o crescimento urbano também se apresentou intensivo. Em todas as situações de adensamento, percebemos claramente uma ligação com as rodovias que funcionam como vetor de indução ao desenvolvimento dessas áreas.

Podemos fazer uma interpretação da morfologia de crescimento urbano, com origem do centro da RMSP com o formato alongado como "dedos" ou "tentáculos" que vão se estendendo ao longo das rodovias de grande fluxo e circulação de veículos. 
MAPA 9 - CONCENTRAÇÃO

DE CRESCIMENTO DE

ÁREAS URBANAS

\section{LEGENDA}

a." LIMITE DA ÁREA DE

ABRANGENCIA DO ESTUDO

HIDROGRAFIA PRINCIPAL

- SEdes municipais na ÁREa

HWH FERROVIAS

- RODOVIAS

CONCENTRAČ̃A

CRESCIMENTO URBANO

USO DO SOLO

ÁREA URBANIZADA

HABITAÇÕES PRECÁRIAS

INDÚSTRIA

MINERAÇÃO

CHACARAS

ATERRO SANITÁRIO E LIXÃO

SOLO EXPOSTO

VEGETAÇÃO

VEGETAÇÃo DE VÁRZEA

ESPELHO D'ÁGUA

RESERVATÓRIO DE RETENÇÃO

OUTROS USOS

FONTE DOS DADOS EMPLASA, 2006

Projeção Universal Tranversa

Mercator (UTM) Fuso 23

Elipsóide South American Datum (SAD) 1969

Organização dos dados e Elaboração:

Júlia R. Leite, (2011).

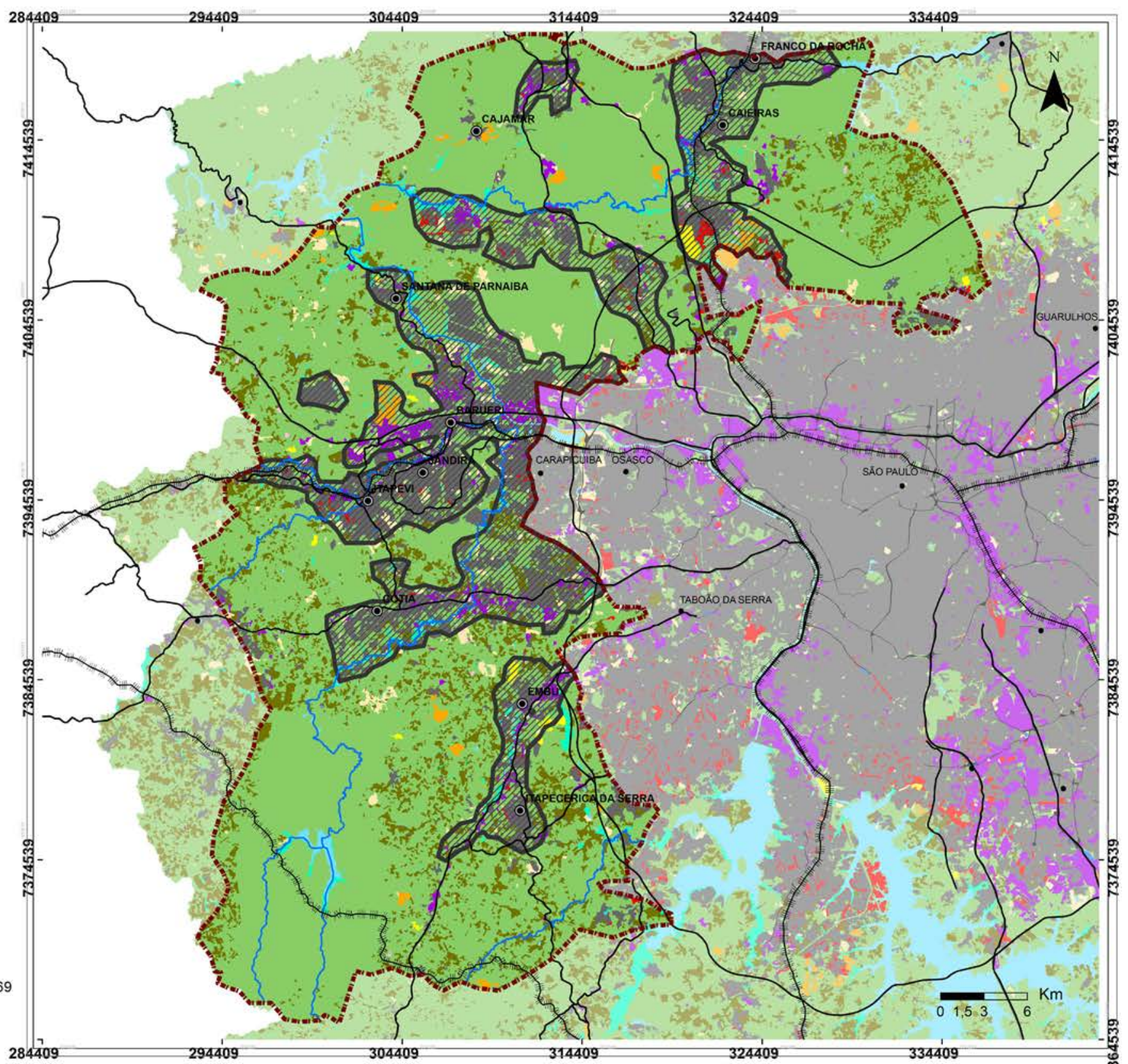


Para concluirmos este capítulo, temos que a área de abrangência deste estudo representa aquela em que o sistema de corredores será desenvolvido, ou seja, a delimita espacialmente. Além do mais, o processo de sua definição indica os objetivos e as características do sistema de maneira mais clara e contextualizada.

As informações a respeito da dinâmica temporal da paisagem estudada nos permitiram direcionar as investigações de planejamento ecológico da paisagem regional para os pontos em que os vetores de crescimento vêm causando transformações e impactos mais significativos em seus elementos naturais. Ou seja, serviu como uma base para a estratégia de desenhar um contínuo de elementos naturais, o qual deve, portanto, lidar com situações de barreiras aos fluxos ecológicos, que são resultantes dos processos de crescimentos urbano, da presença de rodovias e estradas e da supressão da vegetação, elemento natural cuja existência é de fundamental importância, tanto para a manutenção da biodiversidade da área, como dos recursos hídricos e para a qualidade de vida da população. Não apenas a vegetação arbórea, mas todas as áreas seminaturais, como os campos e solo exposto, os trechos de natureza mais ou menos intocada presentes, que possuem a potencialidade estratégica para recuperação e criação de paisagens que combinem uma conservação ecológica/ ambiental com os usos urbanos.

No capítulo seguinte, analisamos a área aqui caracterizada, para que seja revelado o cerne do sistema de corredores, que são os locais que detêm os valores ecológicos da paisagem. 


\section{IDENTIFICAC̣̃̃O DE ÁREAS COM POTENCIAL PARA O ESTABELECIMENTO DE CORREDORES ECOLÓGICOS}




\section{CAPÍTULO 3 \\ IDENTIFICAÇÃO DE ÁREAS COM POTENCIAL \\ PARA O ESTABELECIMENTO DE CORREDORES ECOLÓGICOS}

Neste capitulo foi realizado um aprofundamento do conceito da Estrutura Ecológica da Paisagem e uma maior definição da Morfologia Natural da Paisagem, dentro da área de estudo para os possíveis corredores ecológicos. O estudo dessas estruturas espaciais constituiu uma metodologia eficiente, que permitiu uma interpretação integrada dos diversos elementos da paisagem natural.

Buscamos também explorar e demonstrar os instrumentos conceituais e técnicos relacionados ao Sistema de Informações Geográficas (SIG) que foram empregados nos processos de avaliação da paisagem para a obtenção de dados e interpretações sobre a paisagem natural. Os dados obtidos foram aplicados aos conceitos e princípios de planejamento ecológico da paisagem que nortearam esta investigação.

$\mathrm{Na}$ segunda parte do capítulo, foram identificadas as Unidades da Paisagem, etapa fundamental para a busca de uma definição para os Corredores. Os princípios e fundamentos são muito semelhantes ao da etapa anterior, mas neste momento, pudemos partir de um maior detalhamento para as etapas de cruzamento de informações por meio de diagramas e matrizes e o agrupamento das informações em unidades, que auxiliaram na organização dos dados e procedimentos a seguir.

Com isso obtivemos matrizes de cruzamentos de dados e novos mapeamentos que ajudaram a conformar um mapa síntese: “Áreas com Valor Ecólogico”, o que possibilitou a definição dos Corredores Ecológicos na escala de abrangência adotada.

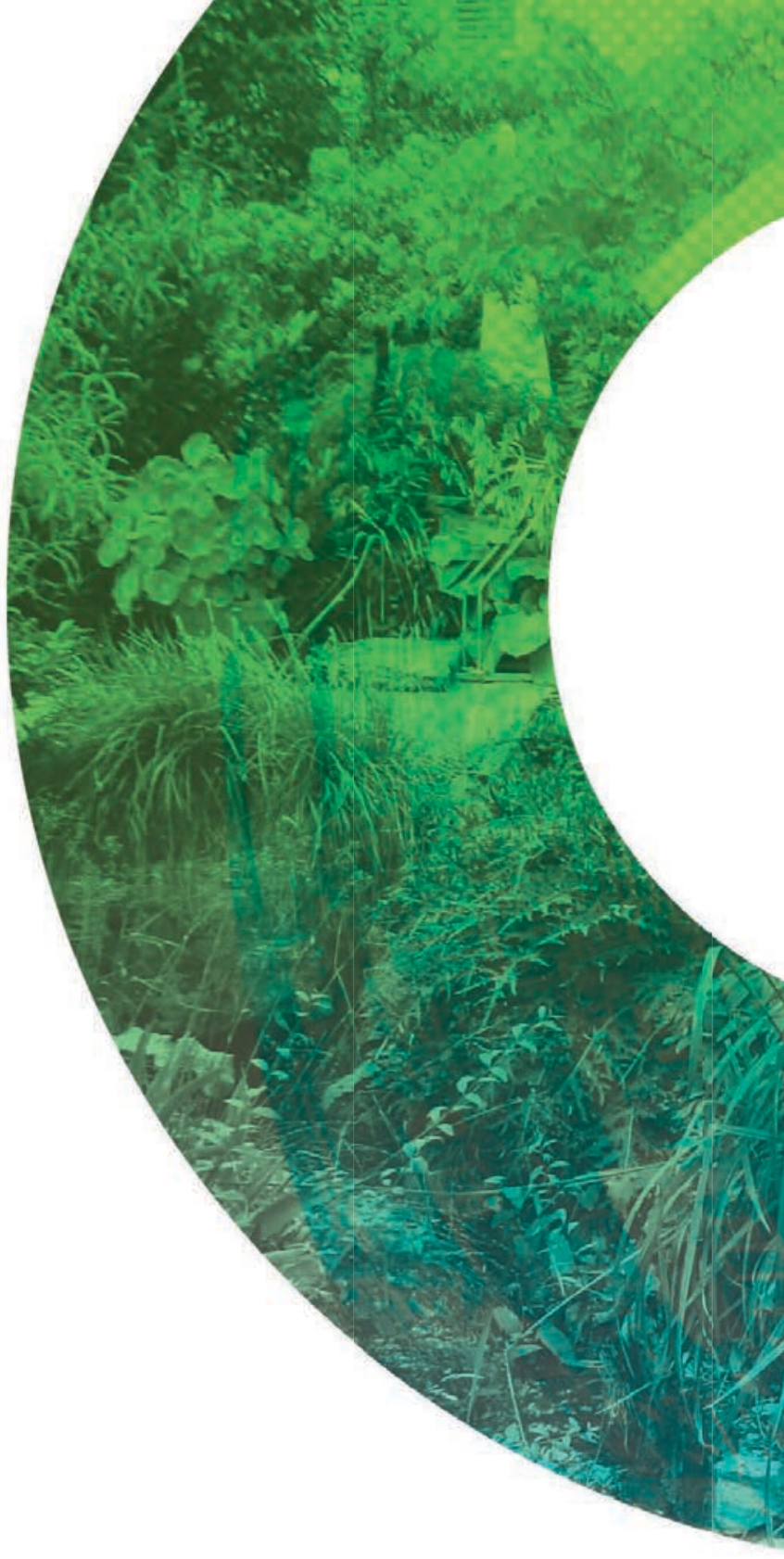




\subsection{A MORFOLOGIA NATURAL DA PAISAGEM DA ÁREA ESTUDADA}

Nesta primeira etapa do trabalho, como já dito, definimos a Morfologia Natural da Paisagem na área de abrangência. Segundo Magalhães (2007) corresponde a forma que a paisagem possui e que é resultante de suas estruturas naturais.

O estudo dessas estruturas e suas implicações na forma da paisagem constituem uma metodologia eficiente que permite a interpretação integrada dos diversos elementos da paisagem natural. Com isso, a medida que a experiência nesta interpretação, por meio de estudos de caso, é possível estabelecer alguma relações entre a forma da paisagem e a interação entre suas componentes . Por exemplos vales encaixados e suas correspondência com litologias duras ou a situação de planícies aluviais com solos sedimentares e férteis (MAGALHÃES, 2007; CUNHA, 2007).

Outro aspecto importante que podemos retirar da Morfologia Natural da Paisagem é a indicação imediata quanto a possibilidade de ser utilizada por determinadas atividades, como as que requerem edificação ou não, conservação, restauração, uso restrito, riscos de inundações ou deslizamento, aptidão para agricultura, etc.

Assim os fatores usados para definição da Morfologia Natural da Paisagem foram Altimetria, Hipsometria, Hidrografia, Declives, e Morfologia do Terreno. A escala de mapeamento foi a de 1: 140.000. Para a elaboração de todos os mapas e procedimentos de analise foi utilizado o aplicativo ARCView 9.3. Foram excluídas da base de dados os polígonos dos shapefiles com áreas inferiores a $0,01 \mathrm{~km}^{2}$, considerados como residuais, e iriam prejudicar a avaliação dos resultados. A resolução dos pixels dos rasters, definidos em formatos grids 


\subsubsection{ALTIMETRIA E HIPSOMETRIA}

De extrema importância para o presente estudo são as curvas altimétricas do terreno fornecidas pela EMPLASA (2006) em que as mesmas são formadas por curvas mestras marcadas a cada $125 \mathrm{~m}$ e pelas auxiliares com $25 \mathrm{~m}$ de eqüidistância.

A carta hipsométrica foi elaborada sobre a base altimétrica (curvas de nível e pontos de altitude). Foram definidas 10 classes de altimetria entre 700 e 1200 metros, correspondendo cada uma delas a um intervalo de $50 \mathrm{~m}$.

Foi produzido o Modelo Digital do Terreno ( Mapa 12) pela triangulação dos pontos entre as cotas do terreno em formato digital (TIN). Este resultado, além de ser uma informação essencial para avaliações da paisagem como a definição de classe declividade, representa muito bem a morfologia do terreno.

Da interpretação da cartografia, Mapa 10, Mapa 11 e Mapa 12, constata-se que a maior parte da diversidade altimetrica que caracteriza a área estudada se reflete na presença de algumas áreas de cumeada (zonas altas) entre um planalto composto por talvegues (zonas mais baixas). É possível diferenciar duas situações altimetricas associadas a situações morfológicas específicas. A primeira delas reúne as cotas mais baixas, ainda que presentes em cotas acima do mar, dentro do planalto paulista, e constituem morfologias da paisagem conotadas com a presença e acumulação de água - as várzeas do Rio Tietê, do Rio Cotia, do Rio Juqueri, Rio Embu-Mirim e Rio Barueri-Mirim. É nas várzeas do rios Tietê e Juqueri em que as cotas mais baixas encontram maior expressão.

O segundo conjunto, onde temos as cotas mais elevadas, corresponde aos maciço da Serra da Cantareira e a ao Morro Grande, e que no primeiro temos uma altimetria acima de $950 \mathrm{~m}$ atingindo a cota máxima encontrada de $1200 \mathrm{~m}$ e no segundo uma altimetria superior a $900 \mathrm{~m}$ com uma cota máxima de 1050 ( isso no trecho da reserva compreendido na área de estudo). Há uma terceira colina, Morro do Boturuna, que se destaca na área de estudo, com as cotas altimetricas que variam de $900 \mathrm{~m}$ a $1100 \mathrm{~m}$. 

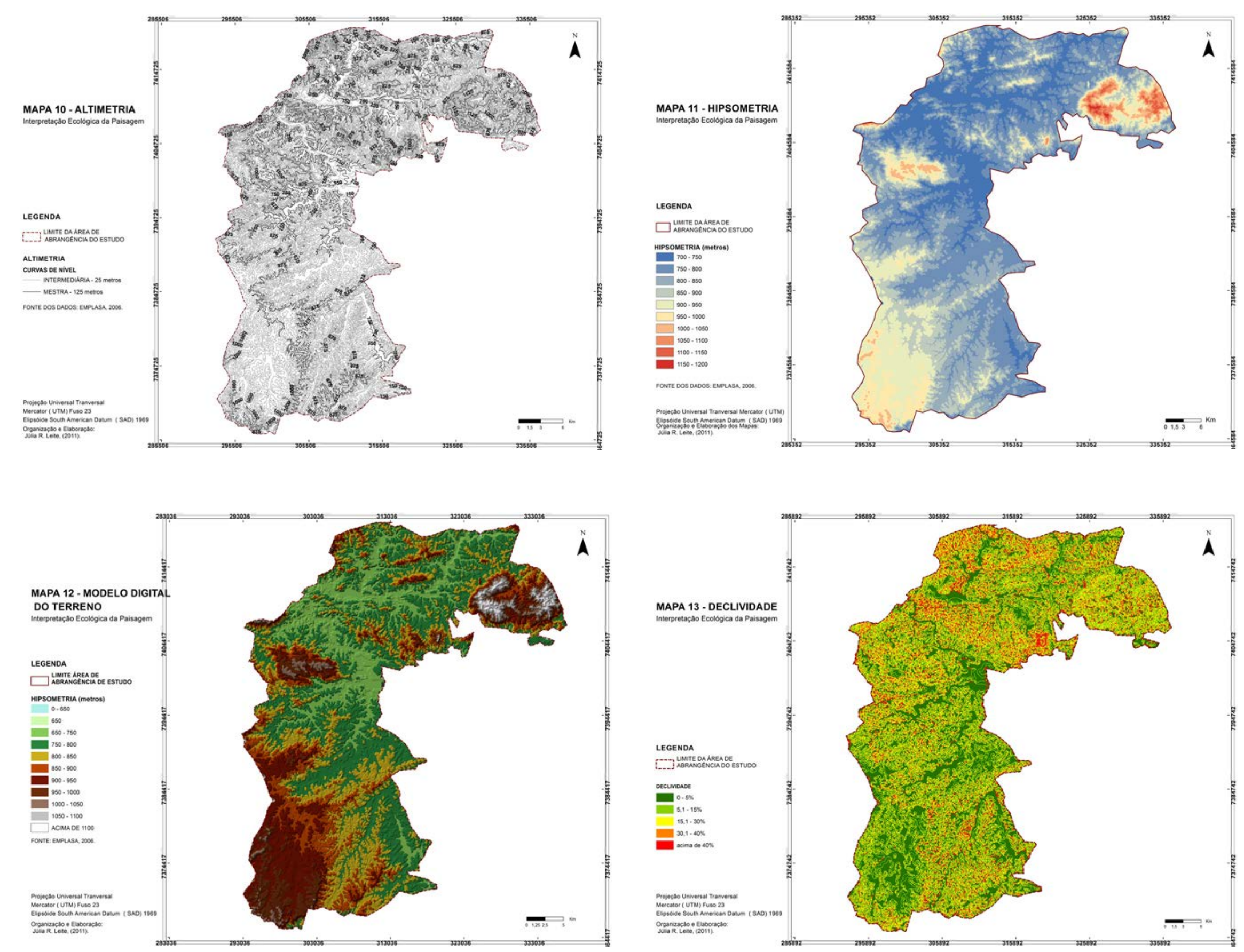


\subsubsection{DECLIVIDADE}

O mapa de declividades (Mapa 13 a seguir) foi elaborado a partir do TINGRID, produzido pela ferramenta 3D Analyst. Foram definidas 5 classes de declive 0-5\% (muito fraca); 5-15\% (fraca); 15-30\% (média); 30-40\% (alta) e acima de 40\% (muito alta) (Tabela 6).

As classes de inclinação do terreno foram escolhidas por seguirem as recomendações técnicas recomendadas por ROSS (1994), Lei de Lehman ${ }^{35}$ e do Código Florestal Brasileiro36 que consideram a relação da inclinação de terrenos com a aptidão para conservação e preservação, bem como de área inapropriadas para ocupação, por se tratarem de riscos de deslizamentos de encostas. Para classes de inclinação mais especificas, que vislumbram outras atividades, como espaços edificados e usos agrícolas, não podem ser definidas com a base altimetrica disponibilizada, já que as cotas, da base dados, são muito espaçadas de forma que a geração dos modelos digitais do terreno originam classes de inclinação com resolução de baixa acuidade. Entretanto para a dimensão e escala de trabalho em estão sendo produzidos os mapas e analises as cotas utilizadas atendem muito bem aos resultados.

O mapa produzido constitui um instrumento de análise para subsidiar a discussão proposta em torno da área de estudo, sobretudo por meio da identificação das áreas planas (0-5\% de inclinação) localizadas nas margens dos corpos d'água e daquelas áreas planas que estão localizadas sobre as linhas divisórias de subbacias hidrográficas e que acabam formando topos de morros largos.
${ }^{35}$ Lei Lehman - Legislação Federal n. 6766/79 que dispõe sobre o parcelamento do solo urbano e não permite o parcelamento do solo em terrenos com declividade igual ou superior a 30\% (trinta por cento), salvose atendidas exigências específicas das autoridades competentes.

${ }^{36}$ Lei Federal no. 4771, 15 de Setembro de 1965 alterada pela Lei Federal no. 7803 de 15 de Agosto de 1989. Foi alterado novamente em 2011 , pela aprovação do novo Código Florestal (Projeto de Lei 1876/99), que permite alguns usos nas áreas de preservação permanente (APPs). Com relação a ocupação de encostas e de altimetrias elevadas o novo código permite nos topo de morros, montes e serras com altura mínima de 100 metros e inclinação superior a $25^{\circ}$, a manutenção de culturas de espécies lenhosas ou de atividades silviculturais, assim como a infra-estrutura física associada a elas.

TABELA 6 - Classes de declividade encontradas, em área $\left(\mathrm{km}^{2}\right)$ e percentuais da área total (\%).

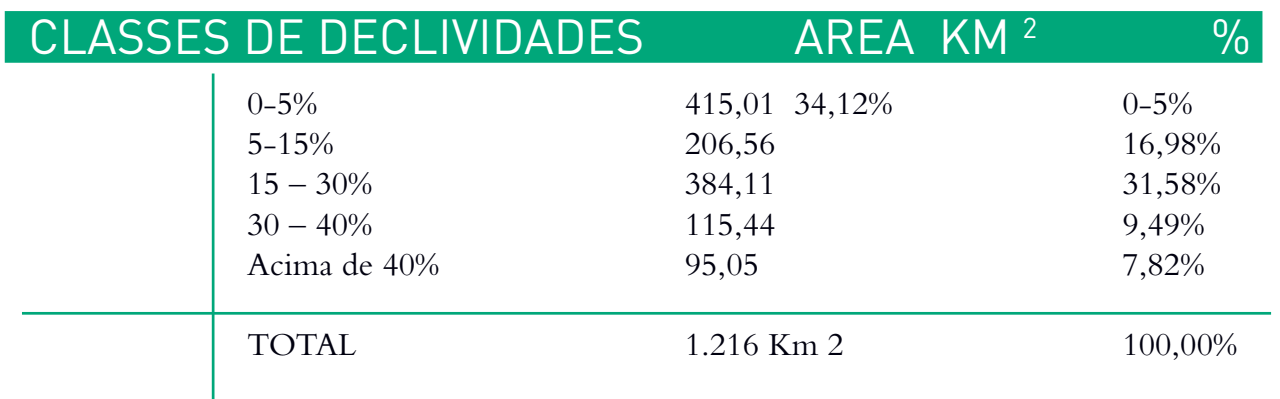


$\mathrm{Na}$ área de estudo predominam os declives suaves, os inferiores a 5\% de inclinação muito fraca, correspondendo a $34,12 \%$ da área total estudada. A segunda classe de inclinação, com maior predominância é a de declives médios, compreendida entre 15-30\%. Em seguida observamos a terceira predominância para a classe de declividades fracas, entres as inclinações 5-15\% que corresponde a $16,98 \%$ da área total. Para as inclinações altas e muito altas observamos um percentual de $9,49 \%$ e 7,82\% respectivamente. Podemos afirmar que as implicações de declives acentuados não são as características mais fortes da área estudada, e sim os problemas decorrentes de uma presença intensa de declividades muito fracas, ou seja indicam uma maior propensão a enchentes e inundações.

\subsubsection{REDE HÍDRICA}

A rede hídrica utilizada foi a fornecida pela EMPLASA (2006), proveniente do mapeamento da Região Metropolitana de São Paulo. A rede hídrica sofreu algumas correções em suas linhas e formatos tendo-se como base a altimetria (EMPLASA, 2006) e em algumas situações, também o mosaico de ortofotos para a área estudada (EMPLASA,2007) onde ambos nos indicaram que as correções eram necessárias. Em consulta ao site do Plano de Bacia do Alto Tietê, extraiu-se informação acerca dos principais rios que estão presentes na área de estudo: Rio Tietê, Rio Cotia, Rio Juqueri, Rio Embu-Mirim e Rio Barueri-Mirim.

Não foi realizada a hierquização mais precisa da ordem dos cursos d'agua e as principais subbacias dentro da área de abrangência pela indisponibilidade destes dados prontos para toda a área estudada nas agencias e fontes consultadas. Apenas indicamos os rios principais com nomes e seus tributários que puderam ser identificados o que nos dá uma idéia geral do movimento hídrico da drenagem que segue a direção das área mais baixas e planas, ou seja na direção nos cursos d'água principais.

Como pode ser visualizado no Mapa 14 a rede hídrica bastante densa e ramificada é decorrente da topografia da área, típica de uma planalto, e faz com que ocorra a predominância de área mais planas e conseqüentemente de várzeas, para onde convergem as principais linhas d'água, e com isso se configura uma homogeneidade na paisagem. Nos trechos onde temos alguns vales encaixados, como na Serra da Cantareira, no Morro Grande e no Morro do Boturuna a rede hídrica adquire uma conformação mais ramificada e com caráter ainda mais denso, com a presença de mais nascentes, como é característico de tais situações morfológicas. 
MAPA 14 - REDE HÍDRICA Interpretação Ecológica da Paisagem

\section{LEGENDA}

LIMITE DA AREA DE
ABRANGENCIA DO ESTUDO
LIMITE DA RMSP

- RIOS PRINCIPAIS ÁREA DE ESTUDO

- REDE HIDRICA

REDE HIDRICA DA RMSP

ESPELHOS D'ÁGUA

RESERVATÓRIOS DE RETENÇÃO

VEGETAÇÃO DE VÁRZEA

DIVISÃO DE SUBBACIAS ALTO TIETÊ COTIA-GURAPIRANGA

JUQUERI-CANTAREIRA

JUSANTE-PINHEIROS-PIRAPORA PENHA-PINHEIROS

FONTE DE DADOS: EMPLASA, 2006;
PLANO DA BACIA DO ALTO TIETE, 2002

\section{Projeção Universal Tranversal}

Mercator (UTM) Fuso 23

Elipsoide South American Datum ( SAD) 1969

Organizaçăo e Elaboraçăo:
Júlia R. Leite, (2011).

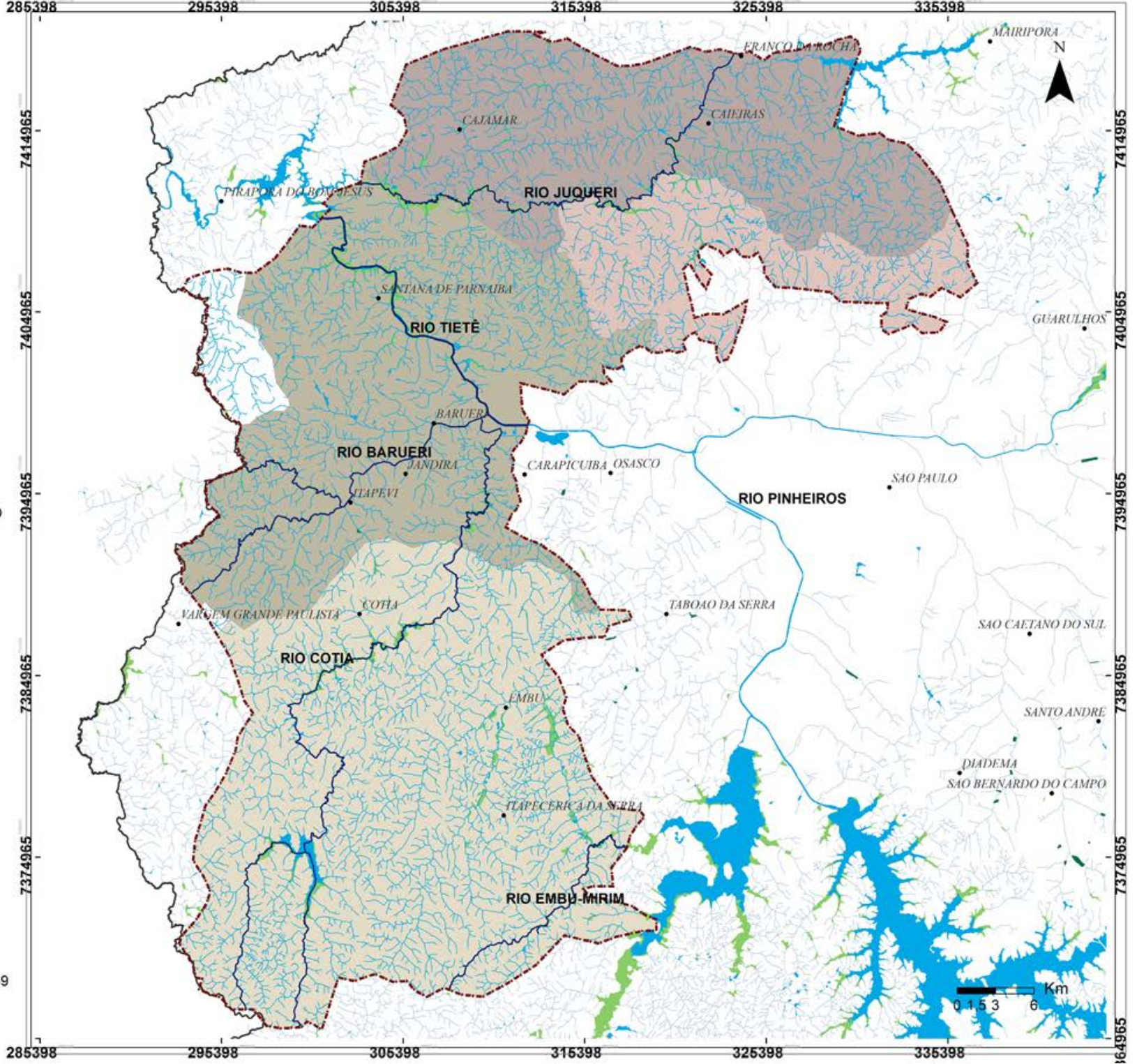




\subsubsection{MORFOLOGIA DO TERRENO}

Morfologia do terreno corresponde a forma global do terreno, sua base fisica, e constitui um importante indicador do comportamento dos processos ecológicos, cuja tradução em planta e se possível em maquete, é um instrumento muito útil para a compreensão da paisagem (Magalhães, 2001). O Mapa da Morfologia do Terreno foi produzido com base no Mapa da Hidrografia e Mapa de Declividade, que deram origem a três situações ecológicas fundamentais determinadas pelo relevo: os topos de morros, as encostas e as áreas planas adjacentes as linhas d'água.

A partir da informação gerada acerca da declividade do terreno, iniciou-se o trabalho sobre as áreas com as inclinações muito fracas, ou seja, aquelas com inclinação no terreno inferiores a 5\%. Por um processo automático, as áreas planas adjacentes a rede hídrica foram diferenciadas das demais áreas planas, considerando-se assim as primeiras integrantes do sistema úmido da paisagem e as demais pertencentes ao sistema seco (as encostas e topos de morros). A morfologia do terreno pode ser visualizada no Mapa 15 a seguir.

\section{SISTEMA SECO - TOPOS DE MORROS E ENCOSTAS}

Os topos de morros são constituídos pelas linhas divisoras de bacias hidrográficas e por áreas mais ou mesmo planas que são contiguas as linhas, e podem ter larguras variáveis e até mesmo se apresentarem apenas por meio das linhas divisórias.

As áreas planas do Sistema Seco constituem os topos dos morros e foram todas interligadas manualmente pelos os divisores de bacia. Todos os polígonos resultantes do processamento automático tiveram que ser revistos manualmente e corrigidos em seus formatos e em muitas das suas sobreposições conflitantes.

Os topos de morros em geral encontram-se mais susceptíveis à erosão e aos ventos dominantes do que as demais situações determinadas pelo relevo; é a partir dessas situações que a água pluvial é escoada em direção as cotas mais baixas, que de uma perspectiva estritamente ecológica os permite classificar, segundo Magalhães (2001), como 
“zonas de elevada sensibilidade, cuja degradação produz extensas alterações no padrão de funcionamento de toda bacia hidrográfica. Tanto no nível da erosão, como do ciclo hidrológico"

( MAGALHÃES, 2001:343).

É nos topos de morros, sobretudo naqueles que são mais alargados, que os riscos de inundações dos fundos de vale pode ser minimizados, por meio da re-vegetação apropriada que permita a infiltração e retenção das águas. No entanto se os topos de morros apresentarem dimensões apropriadas para ocupação, assumindo formas de planaltos, poderão suportar edificações e infraestruturas urbanas. Mesmo dentro desta perspectiva de utilização deve-se ressalvar a existência e manutenção de faixas de vegetação nas bordas do planalto assegurando a proteção contra ventos, erosão e implementando a infiltração de águas pluviais ( MAGALHÃES, 2001)

As encostas (vertentes) são caracterizadas por serem áreas que mais concorrem para verter águas nas linhas d'água. Litologias mais duras geram encaixes mais profundos das linhas d'água e declives mais acentuados das vertentes. Segundo Magalhães (2001) são essas as situações de relevo mais aptas a receberem edificações e instalação de culturas agrícolas.

\section{SISTEMA ÚMIDO - ÁREAS ADJACENTES AS LINHAS D’ÁGUA}

O Sistema Úmido das bacias hidrográficas é formado pelas linhas d'água e respectivas áreas adjacentes (várzeas) e correspondem a áreas planas ou côncavas onde água e ar frio se acumulam. São nessas áreas onde esse acumulam os materiais transportados das cotas mais altas e ao longo de todo o percurso, dando posteriormente origem aos aluviossolos que representam elevada aptidão para a produção de biomassa.

Um quadro síntese (Quadro 4) foi montado com os elementos que vem sendo estudados para a composição da Estrutura Ecológica da área estudada. Alguns dos elementos componentes da estrutura ecológica fundamental como a Orientação Solar, Aqüíferos, Geologia, Valor Ecológico dos Solos são apenas mencionados no quadro. A geologia foi abordada neste trabalho e será apresentada a seguir, os demais componentes não serão tratados neste trabalho. 


\begin{tabular}{|c|c|c|c|c|c|c|}
\hline \multicolumn{4}{|c|}{ POTENCIALIDADES } & $\begin{array}{l}\text { AMENTAL - } \\
\text { ESTRUTURA } \\
\text { ECOLÓGICA }\end{array}$ & $\begin{array}{c}\text { EEMENTOS } \\
\text { ÁREAS } \\
\text { COMPLEMENTARES }\end{array}$ & $\begin{array}{l}\text { APTIDÃO A } \\
\text { EDIFICAÇÃO }\end{array}$ \\
\hline \multirow{5}{*}{ 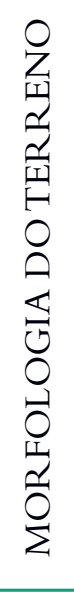 } & \multirow{2}{*}{$\begin{array}{l}\text { Sistema } \\
\text { Úmido }\end{array}$} & $\begin{array}{l}\text { Linhas } \\
\text { d'água }\end{array}$ & & & & \\
\hline & & $\begin{array}{c}\text { Zonas } \\
\text { adjacentes }\end{array}$ & & $\bullet$ & & \\
\hline & \multirow{3}{*}{$\begin{array}{l}\text { Sistema } \\
\text { Seco }\end{array}$} & Encostas & & & & $\bullet$ \\
\hline & & \multirow{2}{*}{$\begin{array}{c}\text { Topos dos } \\
\text { Morros }\end{array}$} & Largos & $\bullet$ & & $\bullet$ \\
\hline & & & Estreitos & $\bullet$ & & \\
\hline \multicolumn{4}{|c|}{ Declividades acentuadas $(>30 \%)$} & & & \\
\hline \multicolumn{4}{|c|}{ Orientação Solar } & & S & $\mathrm{E}, \mathrm{O}, \mathrm{N}$ \\
\hline \multicolumn{4}{|c|}{ Aqüíferos } & $\bullet$ & & \\
\hline \multirow{2}{*}{\multicolumn{3}{|c|}{ Geologia (Permeabilidade) }} & Alta & $\bullet$ & & \\
\hline & & & Baixo & & & \\
\hline \multirow{3}{*}{\multicolumn{3}{|c|}{ Solos (Valor Ecológico) }} & Elevado & • & & $\bullet$ \\
\hline & & & Médio & & $\bullet$ & \\
\hline & & & Baixo & & & $\bullet$ \\
\hline \multicolumn{3}{|c|}{ Vegetação } & & $\bullet$ & & \\
\hline
\end{tabular}


MAPA 15 - MORFOLOGIA DO TERRENO

Interpretaçăo Ecológica da Paisagem

\section{LEGENDA}

LIMITE DA AREA DE

MORFOLOGIA DO TERRENO

LINHAS DE ÁGUAE FAIXA

ZONAS ADJACENTES

TOPOS DE MORROS

ENCOSTAS

FONTE DE DADOS: EMPLASA, 2006.

Projeção Universal Tranversa

Mercator ( UTM) Fuso 23

Elipsóide South American Datum ( SAD) 1969 Organização e Elaboraçăo:

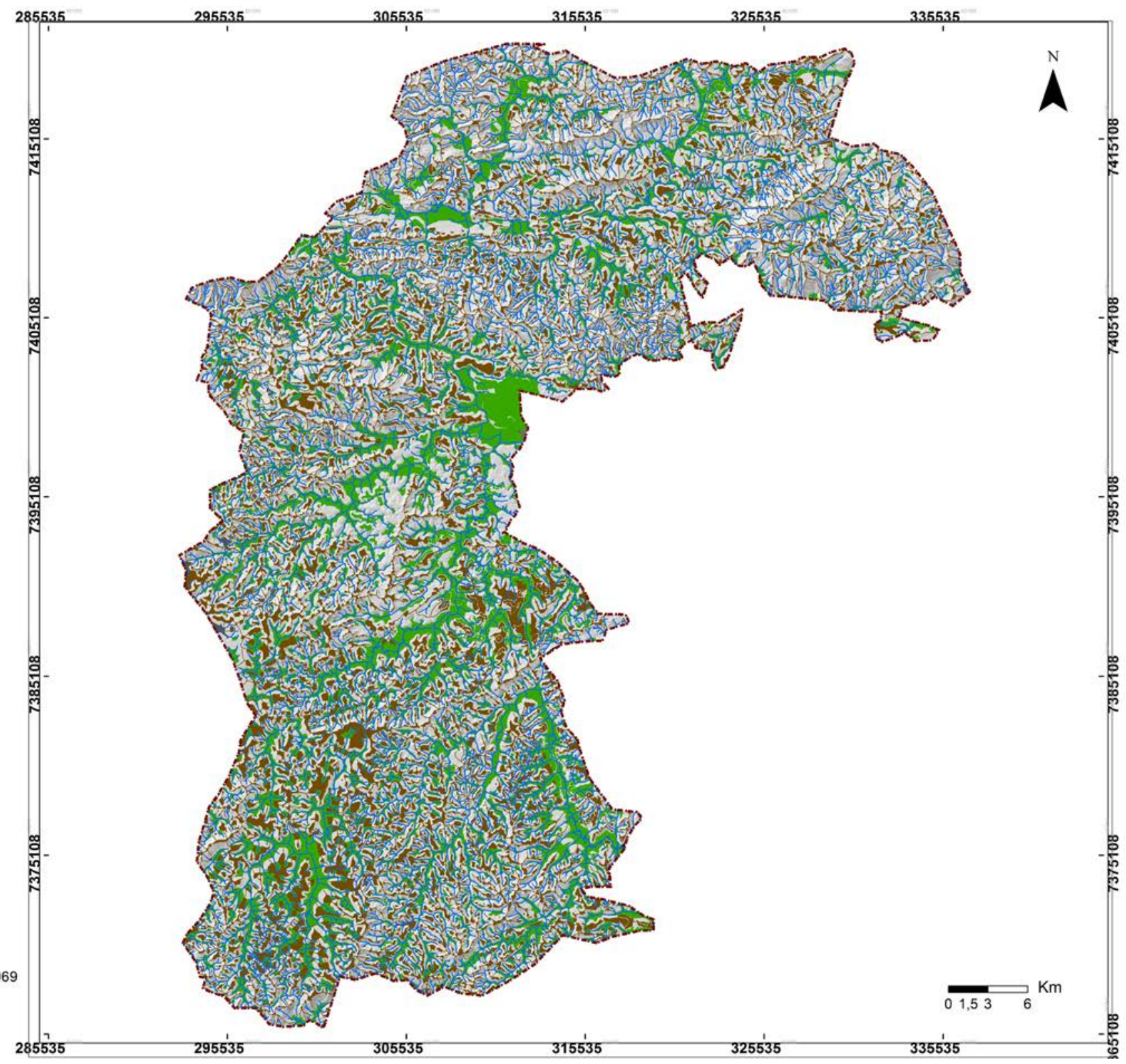




\section{2. UNIDADES DA PAISAGEM}

Complementamos a metodologia da Estrutura Ecológica Fundamental com a metodologia de Unidades da Paisagem ${ }^{37}$. Os princípios e fundamentos são muito semelhantes, mas neste segundo caso, pudemos partir de uma maior organização no material para as etapas de cruzamento de informações por meio de diagramas e matrizes e o agrupamento das informações em unidades, que auxiliaram na organização dos dados e procedimentos.

As Unidades da Paisagem constituem uma síntese de um conjunto de componentes. São unidades espaciais onde existe uma homogeneidade relativa quanto ao seu comportamento e características.

Também obtivemos um melhor suporte operacional e metodológico para as operações realizadas por meio do SIG ArcGIS com a recomendações de Puebla, (2010) de forma a termos mais acuracia da metodologia e da qualidade dos dados obtidos. Com esse suporte metodológico, procuramos reiniciar a avaliação da paisagem e em seguida complementá-la com os resultados obtidos pela Morfologia Natural da Paisagem, onde nenhuma informação anteriormente processada foi perdida e sim adicionada ao próximo resultado. De maneira que pudemos obter uma avaliação dos processos naturais da paisagem mais completa e com menos erros.

\subsubsection{MAPA DE UNIDADES DE RELEVO}

A primeira parte da metodologia consiste em determinar um Mapa de Unidades de Relevo. Um esquema geral que indica de forma geral a metodologia empregada e as principais relações do Sistema de Informações Geográfica (SIG) com a base de dados de elementos da paisagem e poderá esclarecer sobre o procedimento que foi realizado. A base das informações utilizadas foram as mesmas já apresentadas no item anterior. Indicamos no esquema a seguir a maneira como foram abordadas e processadas por meio da metodologia empregada.
${ }^{37}$ Discutida na Disciplina FLG 5057-2 Métodos de Avaliação de Paisagens para

o Turismo e Conservação. Local: Universidade de São Paulo/ Faculdade de Filosofia, Letras e Ciências Humanas/FFLCH. Depto de Geografia. Prof. Responsável: Prof Dr. Eduardo Salinas Chávez ; Agosto a Novembro de 2008. 
DIAGRAMA 1 Elementos principais da relação SIG-Base de Dados dos Elementos da Paisagem.

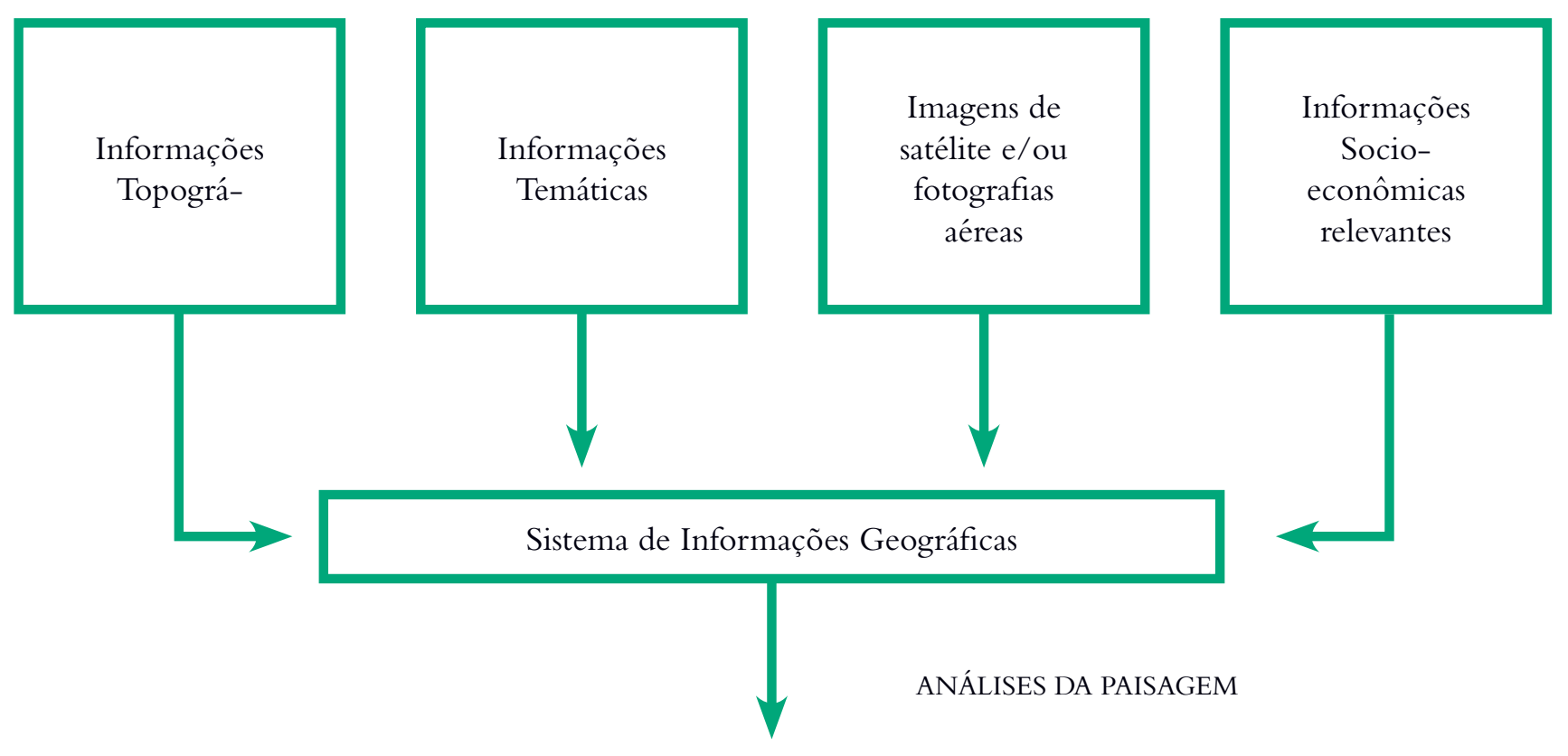

Mapa Preliminar de Unidades da Paisagem

ANÁLISES DA PAISAGEM E TRABALHO DE CAMPO

Mapa das Unidades da Paisagem 
DIAGRAMA 2 - Esquema Geral da elaboração de Unidades da Paisagem.

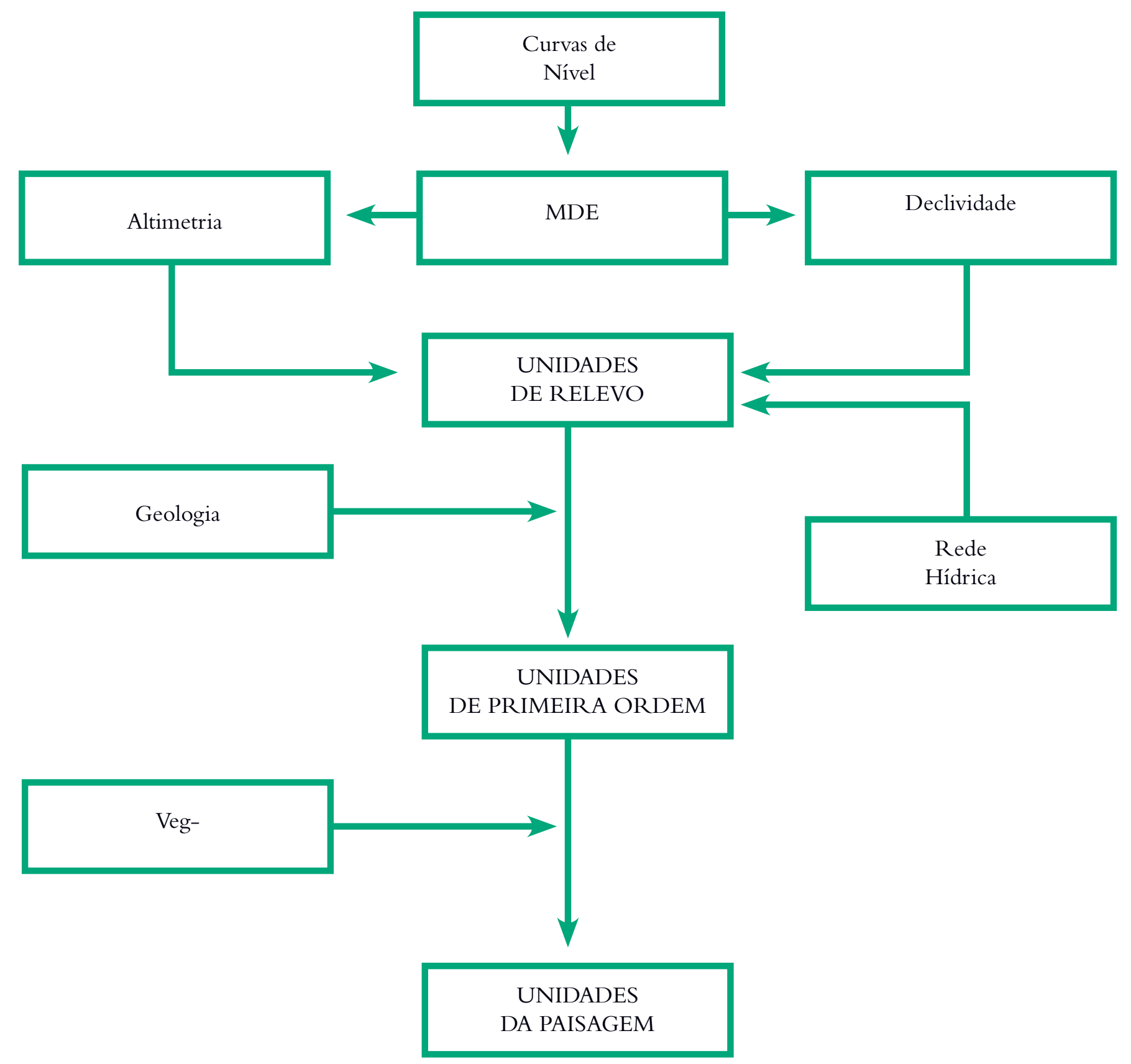


$\mathrm{Na}$ primeira etapa para se chegar a unidades de relevo, foram utilizadas as informações topográficas - altimetria do terreno. Utilizou-se o algoritmo de Delaunay, o qual o software ArcGIS utiliza para calcular o Modelo Triangular do Relevo (TIN).

O Modelo Digital de Elevação do Terreno (TIN) foi obtido pela introdução das curvas altimétricas (EMPLASA, 2006), com equidistancia de 25 metros, no modelo TIN. Por ese motivo empregou-se uma resolução da imagen raster com um pixel de $25 \times 25 \mathrm{~m}$.

TABELA 7 - Classes Altimetricas identificadas na área de abrangência de estudo, com as cotas que as representam e suas características.

\begin{tabular}{c|c|c} 
CLASSES ALTIMETRICAS & COTAS & $\begin{array}{c}\text { CARACTERÍSTICAS } \\
1\end{array}$ \\
\hline 2 & até $900 \mathrm{~m}$ & $\begin{array}{c}\text { Base de colinas maix altas , as } \\
\text { colinas e alguns divisores das } \\
\text { sub-bacias hidrográficas. }\end{array}$ \\
\hline 3 & $1050 \mathrm{~m}-1050 \mathrm{~m}$ & $\begin{array}{c}\text { Morros e Serras, como a Serra da } \\
\text { Cantareira, alguns trechos do Morro } \\
\text { Grande e elevações presentes no } \\
\text { município Santana do Parnaíba. }\end{array}$ \\
\hline
\end{tabular}

O Modelo Digital de Elevação do Terreno (MDT) em formato TIN permite-nos modelar o terreno de modo que é capaz de agregar bem as informação relacionadas ao mass point, os softline e hardline, e é capaz de gerar triângulos exatos aos dados originais (Puebla, 2010). Desta maneira foi escolhido o TIN para gerar o Modelo Digital de Elevação do Terreno, buscando uma maior possível fidelidade com a realidade, bem como as demais informações e dados necessários nesta parte da pesquisa para obtenção das Unidades de Relevo (SALINAS, 2001), e da Morfologia Natural da Paisagem (MAGALHÃES, 2001) e subseqüentemente, a Estrutura Ecológica Fundamental (MAGALHÃES, 2001) e as Áreas de Valor Ecológico (AHERN, 2005SALINAS, 2001; NDUBISi,1995). 
Para obtenção do Mapa e da Matriz de Unidades de Relevo o Modelo Digital de Elevação do Terreno (MDT) foi reclassificado em 3 classes altimetricas. Pela interpretação da paisagem no mapa Altimétrico Geral (Mapa 11 - Hipsometria) onde identificamos de 3 classes altimetricas que deveriam ser consideradas.

De acordo com a Tabela 7 a seguir na Classe 1 estão inseridas as cotas altimétricas inferiores a 900m, e são, portanto, a porção da área mais baixa. Na Classe 2 temos as cotas altimétricas entre 900 e 1050 metros, estas correspondem a base de morros e montanhas na área estudada, ou então, as colinas e alguns divisores das sub-bacias hidrográficas. Na Classe 3 temos as altimetrias mais altas e desta forma correspondem aos morros e montanhas, como a Serra da Cantareira, alguns trechos do Morro Grande e algumas colinas presentes no município Santana do Parnaíba, integrantes da Serra do Boturana.

A etapa seguinte correspondeu a obtenção do Mapa de Declividade e Modelo Digital de Elevação do Terreno (MDT) . O MDT foi agora reclassificado em declividades (SLOPE). As classes de declividades utilizadas foram as recomendadas por Ross (1994) e para a escala de trabalho em que estão sendo feitas as análises da paisagem, estas classes nos trazem informações suficientes acerca as áreas planas (sejam as inundaveis ou os topos de morros), sobre as áreas de inclinações medias e aquelas muito ingrimes, e que sao suceptiveis a deslizamentos, bem como protegidas pelo Código Florestal e pela Lei de Lehman. Assim definimos as seguintes classes de declividade (Tabela 8):

TABELA: Valores das inclinações do terreno que correspondem a cada Classe de Declividade.

\section{CLASSES DE DECLIVIDADES INCLINACÃ̃ (\%)}

\begin{tabular}{c|c}
1 & $0-5 \%$ \\
\hline 2 & $5-15 \%$ \\
\hline 3 & $15-30 \%$ \\
\hline 4 & $30-40 \%$ \\
\hline 5 & Acima de $40 \%$ \\
\hline
\end{tabular}




\subsubsection{MATRIZES}

Matrizes foram empregadas em distintas etapas da avaliação da paisagem. Elas são utilizadas para a caracterização e avaliação de resultados, para a caracterização dos temas estudados e também para determinação dos usos potenciais bem como de geração de impactos. As matrizes apresentam inúmeras vantagens para a metodologia de trabalho pois permitem uma fácil e instantânea combinação dos aspectos avaliados, é de fácil representação, permite uma combinação de análise qualitativa e quantitativa; pode ser modificada pelo usuário (complementada), tem custo baixo para sua elaboração e permite uma possível analise matemática.

Possuem também algumas desvantagens e especificidades de precisam ser levadas em conta de maneira a melhor aproveitarmos os efeitos positivos em trabalhos deste gênero: os resultados que obteremos de suas interpretações são subjetivos, são caucados na compartimentação das variáveis estudadas, promovem a soma de valores heterogêneos e se as matrizes são muito extensas, por meio de muitas quadriculas geram resultados muito complexos .

A primeira matriz de cruzamento de informações foi realizada pela combinação dos polígonos relativos as 3 classes de altimetrias e os 5 polígonos das 5 classes de declividade do terreno. A Tabela 9 contém as informações obtidas pela matriz e a coloração da interpretação de cada uma das unidades, e pode ser visualizada a seguir:

A partir da interpretação e análise do cruzamento obtido, agruparam-se os resultados em unidades morfológicas, onde cada uma recebeu uma coloração para sua identificação. Em seguida elaborou-se uma tabela (Tabela 10) com a numeração de cada uma das unidades de relevo, sua identificação numérica, coloração, características e observações, tais detalhes criados para facilitar a interpretação da análise e incorporação das informações nas análises subseqüentes. 
TABELA 9: Matriz de cruzamento de informações e interpretação das Unidades de Relevo da Paisagem.

\begin{tabular}{|c|c|c|c|c|}
\hline & & 1 & 2 & 3 \\
\hline 1 & $0-5 \%$ & $336,69 \mathrm{~km}^{2}$ & $74,76 \mathrm{~km}^{2}$ & $2,89 \mathrm{~km}^{2}$ \\
\hline 2 & $5-15 \%$ & $162,9 \mathrm{~km}^{2}$ & $44,94 \mathrm{~m}$ & $170 \mathrm{~km}^{2}$ \\
\hline 3 & $15-30 \%$ & $305, \mathrm{o} 6 \mathrm{~km}^{2}$ & $68,85 \mathrm{~km}^{2}$ & $6,28 \mathrm{~km}^{2}$ \\
\hline 5 & ACIMA 40\% & $72,31 \mathrm{~km}^{2}$ & $19,76 \mathrm{~km}^{2}$ & $3,05 \mathrm{~km}^{2}$ \\
\hline
\end{tabular}


TABELA 10: Unidades de Relevo, suas características e observações.

\begin{tabular}{|c|c|c|c|}
\hline $\begin{array}{l}\text { UNIDADES } \\
\text { MORFOLÓGICAS }\end{array}$ & COR & CARACTERÍSTICAS & OBSERVAÇÕES \\
\hline 1 & Verde & $\begin{array}{l}\text { Planices Fluviais - leito } \\
\text { rios, fundo de vales }\end{array}$ & $\begin{array}{l}\text { Áreas com inclinação } \\
\text { entre } 0-5 \% \text {, com variação } \\
\text { altimetrica entre } 720-900 \mathrm{~m}\end{array}$ \\
\hline 2 & Verde & Terraços Baixos Fluviais & $\begin{array}{l}\text { Áreas com inclinação } \\
\text { entre } 5-15 \% \text {, com variação } \\
\text { altimetrica entre } 720-900 \mathrm{~m}\end{array}$ \\
\hline 3 & Verde & $\begin{array}{c}\text { Terraços e Encostas Suaves } \\
\text { de Vales e Colinas }\end{array}$ & $\begin{array}{l}\text { Áreas com inclinação entre } \\
15-30 \% \text {, com variação } \\
\text { altimetrica entre } 720-900 \mathrm{~m}\end{array}$ \\
\hline 4 & & $\begin{array}{l}\text { Encostas Erosivas de } \\
\text { Transição dos Vales }\end{array}$ & $\begin{array}{l}\text { Áreas com inclinação } \\
\text { superior a 30\% com variação } \\
\text { altimetrica entre } 720-900 \mathrm{~m}\end{array}$ \\
\hline 5 & Laranja & $\begin{array}{c}\text { Encostas Suaves de } \\
\text { Colinas, Morros e Serras. }\end{array}$ & $\begin{array}{l}\text { Áreas com inclinação } \\
\text { entre } 5-15 \% \text {, com variação } \\
\text { altimetrica entre } 900-1200 \mathrm{~m}\end{array}$ \\
\hline 6 & Vermelo & $\begin{array}{c}\text { Encostas Médias de } \\
\text { Colinas, Morros e Serras. }\end{array}$ & $\begin{array}{c}\text { Áreas com inclinação entre } 15- \\
30 \% \text {, com variação altimetrica } \\
\text { entre } 900-1200 \mathrm{~m}\end{array}$ \\
\hline 7 & Vermelo & $\begin{array}{l}\text { Encostas Acentuadas } \\
\text { de Morros e Serras }\end{array}$ & $\begin{array}{l}\text { Áreas com inclinação acima } \\
\text { de } 30 \% \text { com variação } \\
\text { altimetrica entre } 900-1200 \mathrm{~m}\end{array}$ \\
\hline 8 & Marron & $\begin{array}{l}\text { Divisores de Bacias } \\
\text { Hidrográficas e Topos } \\
\text { de Colinas, Morros e }\end{array}$ & $\begin{array}{l}\text { Áreas com inclinação entre } \\
0-5 \% \text {, com variação altimetrica } \\
\text { entre } 900-1200 \mathrm{~m}\end{array}$ \\
\hline
\end{tabular}




\section{MAPA 16 - UNIDADES}

DE RELEVO

Interpretação Ecológica da Paisagem

\section{LEGENDA}

LIMITE DA ÁREA DE
ABRANGENCIA DO ESTUDO

HIDROGRAFIA PRINCIPAL

HIDROGRAFIA PRINCIP

— LINHAS DE CUMEADA

UNIDADES DE RELEVO

LEITO DE RIOS E
PLANICES INUNDAVEIS

TERRAÇOS FLUVIAIS BAIXOS

TERRAÇOS E ENCOSTAS

ENCOSTAS EROSIVAS DE

ANSIÇĀO DOS VALES

ENCOSTAS SUAVES DE

ENCOSTAS MEDIAS DE
COLINAS, MORROS E SERRAS

ENCOSTAS ACENTUADAS

TOPOS DE MORROS E SERRAS

Projeçăo Universal Tranversal

Mercator ( UTM) Fuso 23

Elipsóide South American Datum ( SAD) 1969

Organização e Elaboração

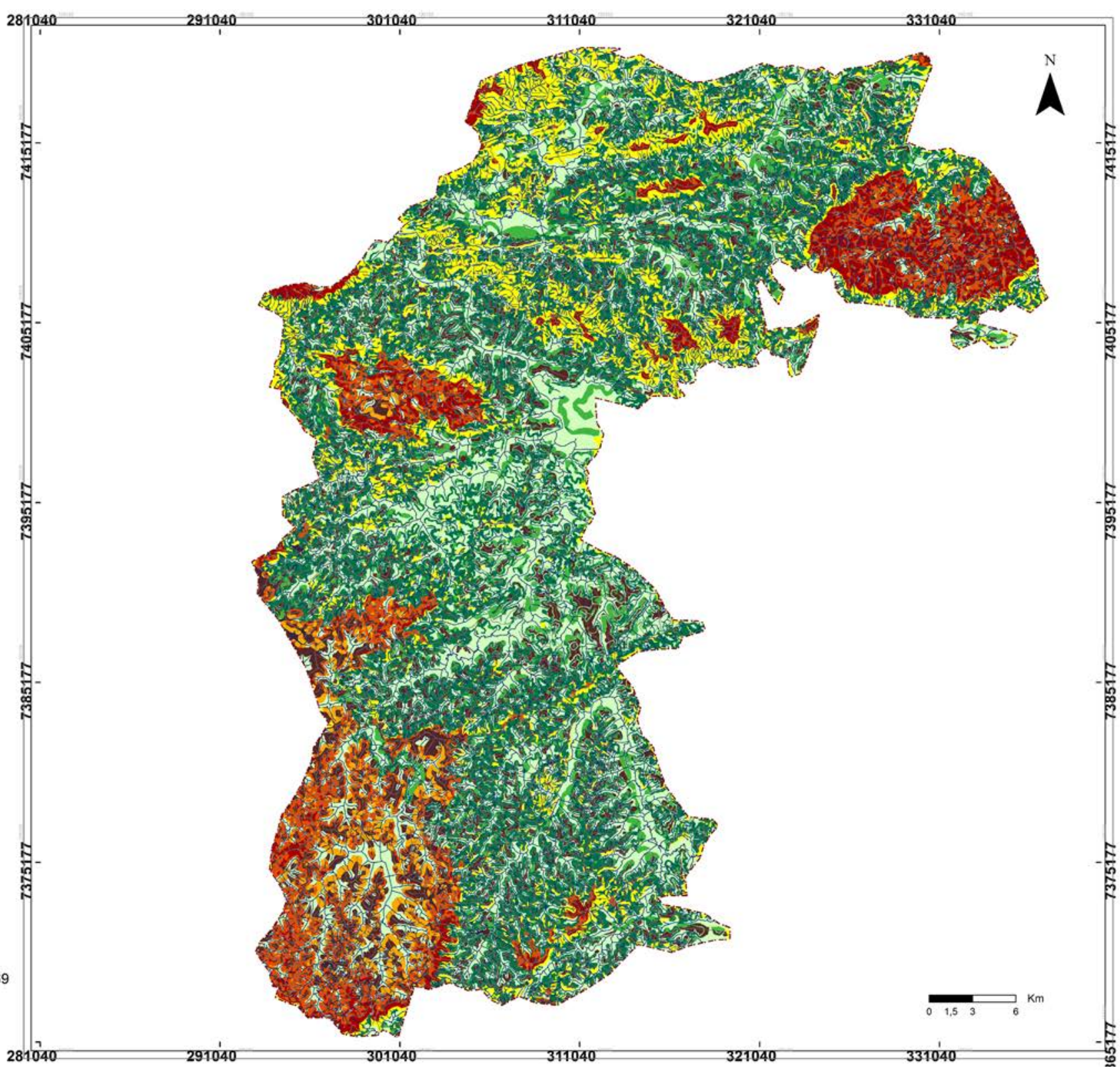




\subsubsection{LITOLOGIA}

A base do Mapa 11, Litologia, foi a Carta Geológica do Estado de São Paulo produzida pela Companhia de Pesquisas e Recursos Minerais, do Ministério de Minas e Energia, e Serviço Geológico do Brasil CPRM/SGB (2010) ${ }^{38}$ A figura obtida foi georrererenciada e digitalizada e as informações foram adicionadas a base de dados do Sistema de Informações Geográficas. Com isso foram realizados cruzamentos de informações, matrizes e mapas, estes dois últimos para representar o novo conteúdo que foi agregado às Unidades de Relevo, anteriormente elaboradas.

As classes de litologia presentes na área estudada foram interpretadas e pudemos identificar 5 classes de litologia conforme pode ser visualizado na Tabela 11 a seguir.

${ }^{8}$ Disponibilizado pelo site http://www.cprm gov. br/ Acessado em 21/01/2010. 
TABELA 11: Interpretação do Mapa Geomorfológico do Estado de São Paulo (CPRM- SGB,2010) para a determinação de 5 classes de Litologia para a área estudada.

\begin{tabular}{|c|c|c|c|c|}
\hline $\begin{array}{c}\text { CLASSES } \\
\text { GEOMORFOLÓGICAS } \\
\text { ESTADO SÃO PAULO } \\
\text { (CPRM, 2010) }\end{array}$ & $\begin{array}{l}\text { DOMÍNIO GEOLÓGICO - } \\
\text { AMBIENTAL }\end{array}$ & $\begin{array}{l}\text { UNIDADE GEOLÓGICO- } \\
\text { AMBIENTAL }\end{array}$ & CARACTERÍSTICAS & UNIDADES LITOLOGIA \\
\hline 01 & $\begin{array}{l}\text { Sedimentos cenozoicos inconsolidados } \\
\text { ou pouco consolidados, depositados } \\
\text { em meio aquoso }\end{array}$ & Planíces fluviais & $\begin{array}{l}\text { Ambiente de planície } \\
\text { aluvionar recente }\end{array}$ & depósitos aluviais \\
\hline 16 & $\begin{array}{l}\text { Sedimentos cenozóicos e mezozëicos } \\
\text { pouco ou moderadamente consolidados }\end{array}$ & Tabuleiros dissecados & Predomínio de sedimentos arenosos & sedimentos arenosos \\
\hline 70 & $\begin{array}{c}\text { Sequencias sedimentares proterozoicas } \\
\text { dobradas metamorfizadas de baixo } \\
\text { grau a medio grau }\end{array}$ & Morros e serras baixas & $\begin{array}{l}\text { Metaarenitos, quartzitos, } \\
\text { metaconglomerados }\end{array}$ & $\begin{array}{l}\text { Vulcanogeno sedimentarias (arenitos, } \\
\text { grauvacas, tufitas, conglomerados, etc.) }\end{array}$ \\
\hline 89 & $\begin{array}{c}\text { Seqüências vulcanossedimentares } \\
\text { proterozoicas dobradas metamorfizadas } \\
\text { de baixo grau a alto grau }\end{array}$ & Morros e serras baixas & Indiferenciado & $\begin{array}{l}\text { Vulcanogeno sedimentarias (arenitos, grau- } \\
\text { vacas, tufitas, conglomerados, etc.) }\end{array}$ \\
\hline 96 & $\begin{array}{c}\text { Sequiências vulcanossedimentares } \\
\text { proterozoicas dobradas metamorfizadas } \\
\text { de baixo grau a alto grau }\end{array}$ & Morros e serras baixas & $\begin{array}{l}\text { Predomínio de metassedimentos } \\
\text { silico-argilosos }\end{array}$ & $\begin{array}{c}\text { Vulcanogeno sedimentarias } \\
\text { (arenitos, grauvacas, tufitas, conglomerados, } \\
\text { etc.) }\end{array}$ \\
\hline 105 & $\begin{array}{c}\text { Sequiências vulcanossedimentares } \\
\text { proterozoicas dobradas metamorfizadas } \\
\text { de baixo grau a alto grau }\end{array}$ & Montanhoso & $\begin{array}{l}\text { Metagrauvaca,metaareno,tufo e } \\
\text { metavulcanica basica eintermediaria }\end{array}$ & $\begin{array}{l}\text { Vulcanogeno sedimentarias (arenitos, } \\
\text { grauvacas, tufitas, conglomerados, etc.) }\end{array}$ \\
\hline 130 & $\begin{array}{l}\text { Complexos granitoides deformados } \\
\text { Colinas dissecadas e morros baixos }\end{array}$ & $\begin{array}{l}\text { Colinas dissecads } \\
\text { morro abixo }\end{array}$ & $\begin{array}{l}\text { Series graniticas subalcalinas: calcio alcalinas } \\
\text { (baixo,medio e alto k) toleticas }\end{array}$ & Granitos \\
\hline 132 & $\begin{array}{l}\text { Complexos granitoides deformados } \\
\text { Colinas dissecadas e morros baixos }\end{array}$ & montanhosos & $\begin{array}{l}\text { Série graníticas subalcalinas: cálcio } \\
\text { alcalinas(baixo, médio e alto K) Toléticas }\end{array}$ & Granitos \\
\hline 135 & Complexos granitoides deformados & Morros e serras baixas & Granitóides peraluminosos & Granitos \\
\hline 139 & Complexos granitoides deformados & Morros e serras baixas & Indeterminado & Granitos \\
\hline 174 & $\begin{array}{l}\text { Granito gnaisse migmatico } \\
\text { e granulitos }\end{array}$ & Morros e serras baixas & Gnaisses indiferenciados & Gnaisse \\
\hline 130,131132 & $\begin{array}{l}\text { Complexos granitoides deformados } \\
\text { Colinas dissecadas e morros baixos }\end{array}$ & $\begin{array}{l}\text { Montanhas_morros } \\
\text { e serras baixas }\end{array}$ & Series graníticas subalcalinas: & Granitos \\
\hline
\end{tabular}


Com a interpretação acima demonstrada definiu-se as 5 classes de Litologia como esta sendo mostrado na Tabela 12 a seguir:

TABELA 12- Classes de Litologia identificadas na área de estudo (CPRM- SGB, 2010).

\begin{tabular}{c|c} 
CLASSES & LITOGIAS \\
1 & Sedimentos \\
\hline 2 & Depositos \\
\hline 3 & Vulcanogeno sedimentarias \\
\hline 4 & Gnaisse \\
\hline 5 & Granitos \\
\hline
\end{tabular}

A Carta Geológica do Estado de São Paulo (CPRM- SGB, 2010) foi interpretada de onde nos foi possível obter as informações sobre domínios geológicos presentes na área estudada os quais nos indicaram de maneira geral duas características importantes, a permeabilidade do solo e a tendência deslizamentos.

A primeira, a permebilidade do solo, ou seja, a propriedade que representa uma maior ou menor dificuldade com que a percolação da água ocorre através dos poros do solo. Nos materiais granulares não coesivos como as areias, por exemplo, há uma grande porosidade o que facilita o fluxo de água através dos solos, enquanto que nos materiais finos e coesivo como as argilas, ocorre o inverso por apresentar baixa permeabilidade.

A permeabilidade do solo, quando se requer uma analise especifica, é representada por coeficientes matemáticos e é determinado por análises especificas de materiais retirados dos locais estudados. No contexto do presente estudo, uma avaliação regional, de uma área metropolitana, 
algumas correlações podem ser feitas entre as formações geológicas (composições litológicas) e suas propriedades de permeabilidade. Essa correlação mesmo que não tão precisas como uma análise realizada com dados de campo pode nos trazer informações importantes sobre a área estudada e nos indicar características que podem ser somadas as informações já obtidas. Lembrando que, para escala de estudo da investigação, um dado desta natureza pode trazer contribuições a discussão e metodologia.

Assim de modo muito geral podemos afirmar que Granitos, Gnaisses e Sedimentos Vuncanogeno-Sedimentares por serem materiais geológicos coesos acarretam em pouca infiltração, onde esta ocorre apenas nas fissuras.Já as rochas sedimentos arenosos possuem maior permeabilidade por permitirem maior infiltração de águas. Também podemos inferir que nas primeiras rochas a tendência a deslizamentos é menor do que no segundo grupo. O mapa das classes litológicas podem ser visualizados a seguir (Mapa 17). 


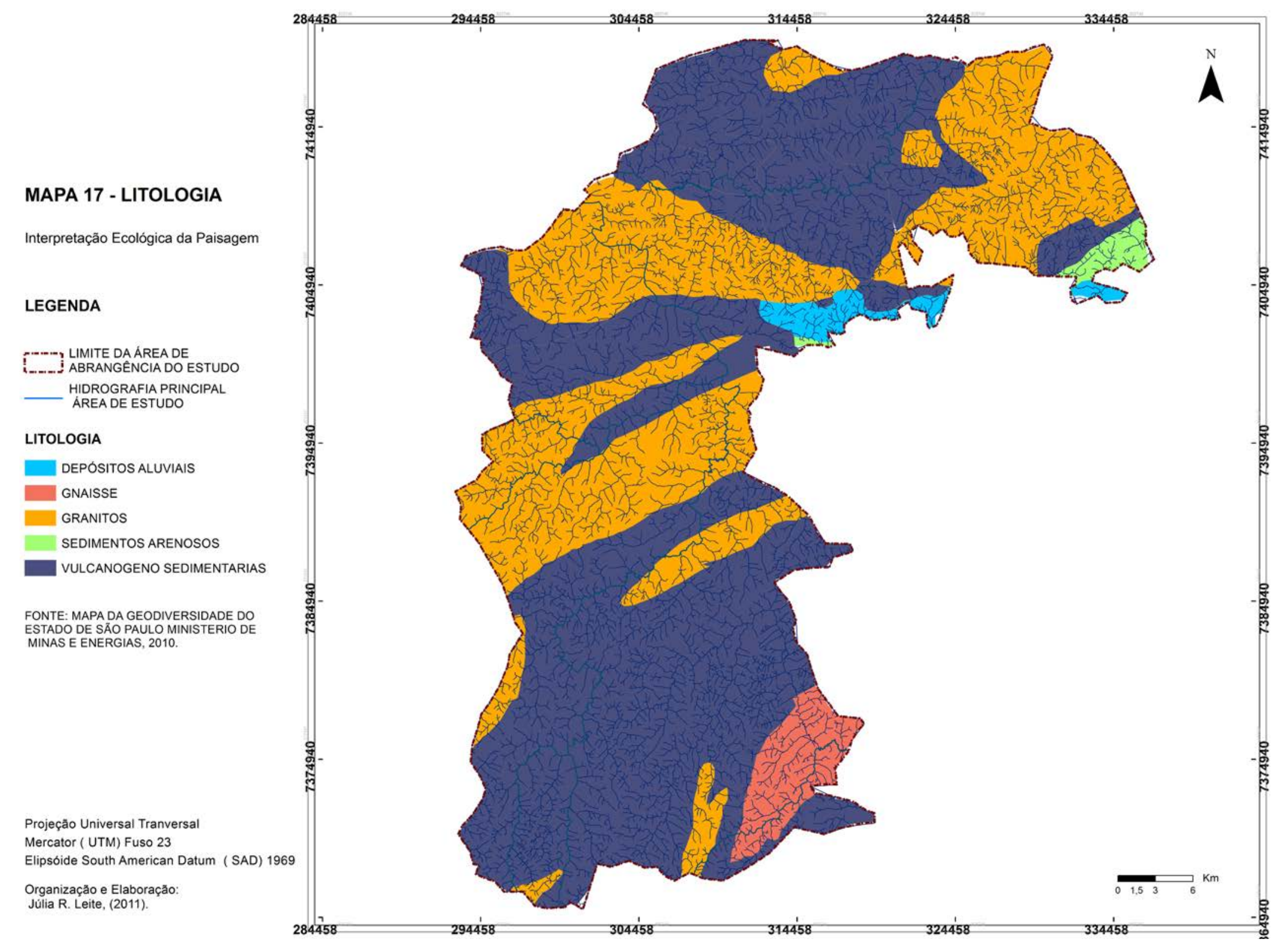




\subsubsection{UNIDADES DE PRIMEIRA ORDEM}

TABELA 13: As nove Unidades da Paisagem $1^{2}$. Ordem encontradas, com suas características e coloração no Mapa 18.

\begin{tabular}{|c|c|c|}
\hline 1 & $\begin{array}{l}\text { litologias moles, (sedimentos arenosos e planices aluviais), } \\
\text { permeáveis, sem risco de deslizamentos, risco de inundações. }\end{array}$ & VERDE CLARO \\
\hline 2 & $\begin{array}{l}\text { litologias moles em terraços fluviais baixos, terraços e encostas suaves } \\
\text { de vales, permeabilidade media, baixa tendência a deslizamentos. }\end{array}$ & VERDE MÉDIO \\
\hline 3 & $\begin{array}{l}\text { litologias duras e permeabilidade baixa (vulcanosedimentares, } \\
\text { gnaisses e granitos), maior estabilidade, em planices inundáveis. }\end{array}$ & VERDE ESCURO \\
\hline 4 & $\begin{array}{l}\text { litologias duras e impermeáveis (vulcanosedimentares, gnaisses e granitos) , maior } \\
\text { estabilidade, terraços fluviais baixos, terraços e encosta leves de vales, encostas suaves } \\
\text { de colinas morros e serras, permeabilidade baixa, baixa tendência a deslizamentos }\end{array}$ & AMARELO \\
\hline 5 & $\begin{array}{l}\text { litologias duras e impermeáveis (vulcanosedimentares, gnaisses e granitos), } \\
\text { maior estabilidade, encostas médias de colinas, morros e serras. permeabilidade } \\
\text { baixa , media tendência a deslizamentos }\end{array}$ & LARANJA \\
\hline 6 & $\begin{array}{l}\text { litologias moles, (sedimentos arenosos e planices aluviais), permeabilidade medias, } \\
\text { encostas suaves e médias de colinas, morros e serras, alto risco de deslizamentos. }\end{array}$ & ROSA \\
\hline 7 & $\begin{array}{l}\text { litologias moles, (sedimentos arenosos e planices aluviais), } \\
\text { permeabilidade medias, alto risco de deslizamentos encostas erosivas de transição } \\
\text { de vales e encostas acentuadas de morros e serras. }\end{array}$ & VERMELHO CLARO \\
\hline 8 & $\begin{array}{l}\text { litologias duras e muito baixa permeabilidade (vulcanosedimentares, } \\
\text { gnaisses e granitos) encostas erosivas de transição de vales } \\
\text { e encostas acentuadas de morros e serras - risco deslizamentos. }\end{array}$ & VERMELHO ESCURO \\
\hline 9 & topos de morros agrupados todos juntos. & CINZA ESCURO \\
\hline
\end{tabular}


A partir do cruzamento das informações da litologia com as Unidades de Relevo obtivemos um mapa de Unidades da Paisagem de $1^{\text {a }}$. Ordem. A Tabela 13 a seguir contém os atributos do cruzamento. Esta ultima foi obtida a partir da interpretação e reorganização dos cruzamentos que deram origem a legenda do mapa e a classificação das 9 Unidades da Paisagem de $1^{\text {a }}$. Ordem ( Mapa 18). A interpretação foi feita com base nas informações das Unidades de Relevo e Litologia, esta ultima com suas implicações gerais sobre permeabilidade e susceptibilidade a deslizamentos. 


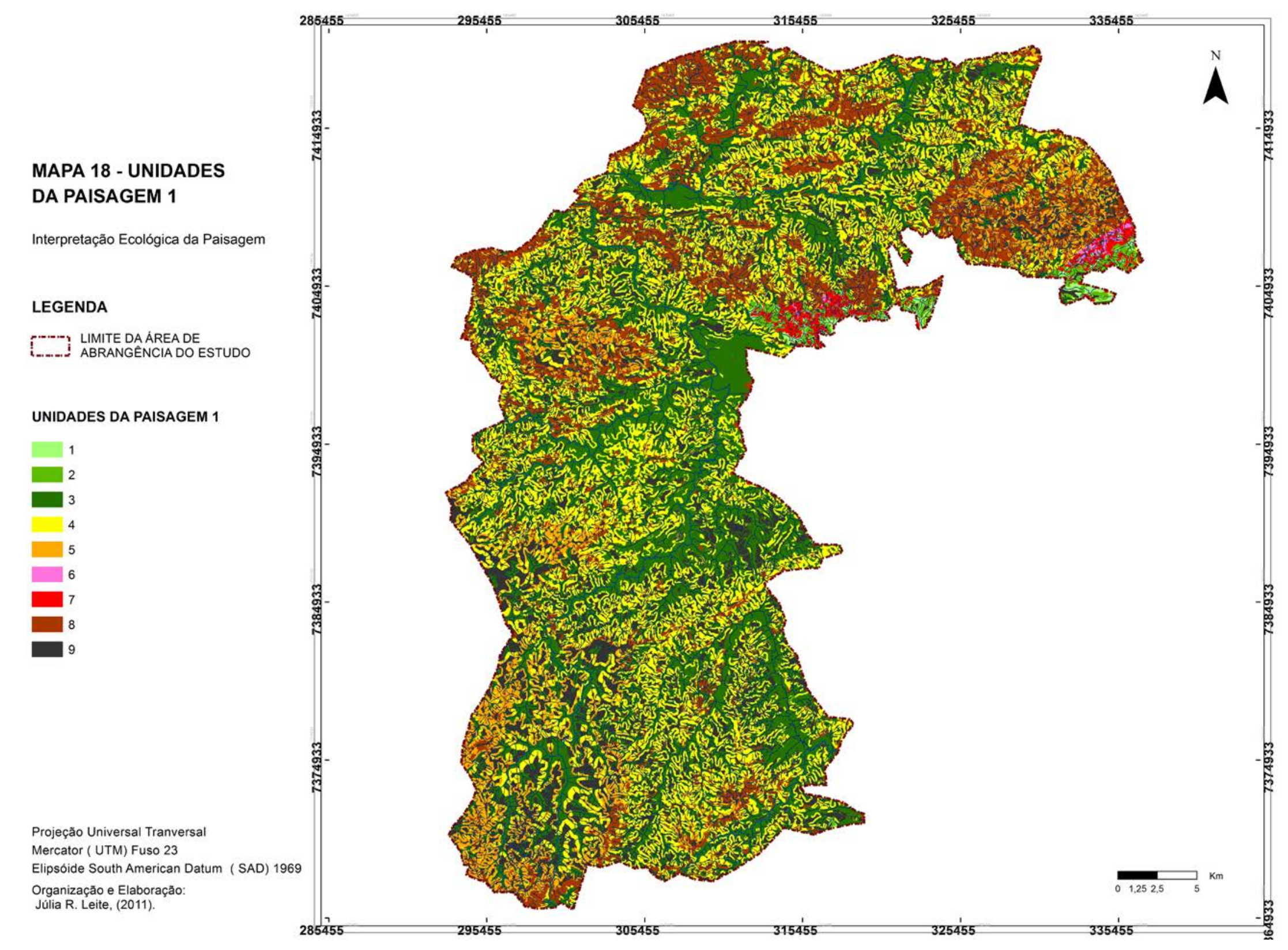




\subsubsection{VEGETACÃ̃/UNIDADES DE CONSERVACָ̃̃O}

Os dados utilizados referentes a vegetação foi o resultado de uma sobreposição de dois levantamentos e mapeamentos da vegetação na área estudada. O primeiro deles foi a base de dados do Levantamento Floristico (IF, 2010) que classifica a vegetação do Estado de São Paulo em Matas e Capoeiras, sendo que primeira corresponde a Floresta Ombrófila madura e a segunda classe corresponde a Vegetação Secundária de Floresta Ombrófila. O segundo dado utilizado foi o da EMPLASA, (2006) do Uso do Solo que contem também classes distintas de vegetação, e classifica o território em áreas deVárzea, Reflorestamento, Campo, Solo Exposto, que são também informações importantes para a pesquisa.

Com os shapefiles contendo polígonos de cada uma dessas classes, as informações foram combinadas, de maneira que priorizamos a classificação do IF, e complementamos com os demais polígonos da EMPLASA. Nos locais em que encontramos matas (EMPLASA, 2006) e o IF, (2010) não havia identificado nada, deixamos a classe da primeira, mas contendo uma distinção na legenda (Mapa 19).

Outra informação de grande importância obtida pelo Instituto Florestal de São Paulo foi a relacionada aos limites de áreas protegidas pela esfera jurídica estadual dentro da área de abrangência. Encontramos as Unidades de Conservação: Parque Estadual da Serra da Cantareira, Reserva Ecológica do Morro Grande, Parque Estadual do Jaraguá e Parque Estadual Juquery, as APAS Estaduais: APA Cajamar e APA Várzea Rio Tietê, Dentre os Parques Municipais de São Paulo, temos o Parque Anhanguera. Outras áreas protegidas como as de caráter municipal, determinadas nos planos diretores municipais, já apresentadas no capitulo 2, foram incorporadas a mapa e poderão, junto com as demais mencionadas, serem visualizadas no mapa a seguir. 
O Mapa da Vegetação e de Áreas de Conservação e Preservação ( Mapa 19), indica o estado de fragmentação da vegetação de porte arbóreo (Matas) no trecho situado entre os parques estaduais Serra da Cantareira e Morro Grande. Ao todo foram identificados 1114 fragmentos de Matas com área superior a $0,01 \mathrm{~km}^{2}$, totalizando um 265,86 $\mathrm{km}^{2}$ desta tipologia de vegetação e que corresponde a 23,14\% da área do trecho de estudado. Para a tipologia Capoeira encontramos 3.428 fragmentos totalizando uma cobertura desta tipologia de $305,22 \mathrm{~km}^{2}$ o que corresponde a $26,56 \%$ da área total. De Vegetação de Várzea temos 142 fragmentos em um total de $16,20 \mathrm{~km}^{2}$ que corresponde a 1,40\% do total. Encontramos 345 fragmentos compostos por Eucalyptos sp e Pinus sp. que somam um total de 146,60 $\mathrm{km}^{2}(12,76 \%)$. Para Campo 1387 fragmentos $(14,41 \%$ da área total). De Chácaras encontrou-se 1352 fragmentos (12,76\%). A ultima tipologia corresponde ao Solo Exposto, que não constitui uma tipologia de Vegetação, mas como corresponde a superfícies permeáveis que podem vir a ser vegetadas, estão incluídas nesta análise. Correspondem a 281 polígonos, e somam uma área de $18,29 \mathrm{~km}^{2}$, ou seja, $1,59 \%$ do total.

As informações apresentadas acima também podem ser visualizadas na Tabela 14 a seguir.

TABELA 14:Tipologias de de área não urbanizadas encontradas na Área de Estudo - RMSP.

\begin{tabular}{l|l|l|l} 
& & & \\
MATA & 1114 & 265,86 & $23,14 \%$ \\
CAPOEIRA & 3428 & 305,22 & $26,56 \%$ \\
CAMPO & 1387 & 165,55 & $14,41 \%$ \\
REFLORESTAMENTO & 345 & 146,60 & $12,76 \%$ \\
CHACARA & 1352 & 88,45 & $12,76 \%$ \\
VEGETAÇÃO DEVÁRZEA & 142 & 16,20 & $1,41 \%$ \\
SOLO EXPOSTO & 281 & 18,29 & $1,59 \%$ \\
& & & $\mathbf{8 7 , 5 7 \%}$
\end{tabular}


MAPA 19 - VEGETAÇÃO

Interpretação Ecológica da Paisagem

\section{LEGENDA}

LIMITE DA ÁREA DE

- REDE HIDRICA RBCV

\section{CLASSES DE VEGETAÇÃO} (IF, 2010; EMPLASA, 2006)

MATA

CAPOEIRA

REFLORESTAMENTO

VEGETAÇÃO DE VÁRZEA

CHACARA

CAMPO/CAPOEIRA

SOLO EXPOSTO

\section{ÁREAS PROTEGIDAS}

(INSTITUTO FLORESTAL, 2010) CATEGORIAS MÁXIMAS DE UNIDADES DE CONSERVAÇÃo APAS ESTADUAIS APAS MUNICIPAIS

MACROZONAS, ZONASE 促

FONTE DE DADOS: EMPLASA, 2006: INSTITUTO FLORESTAL (IF), $2010 ;$
PLANOS DIRETORES MUNICIPAIS.

Projeção Universal Tranversa

Mercator ( UTM) Fuso 23

Elipsóide South American Datum (SAD) 1969

Organização e Elaboração:

Júlia R. Leite, (2011).

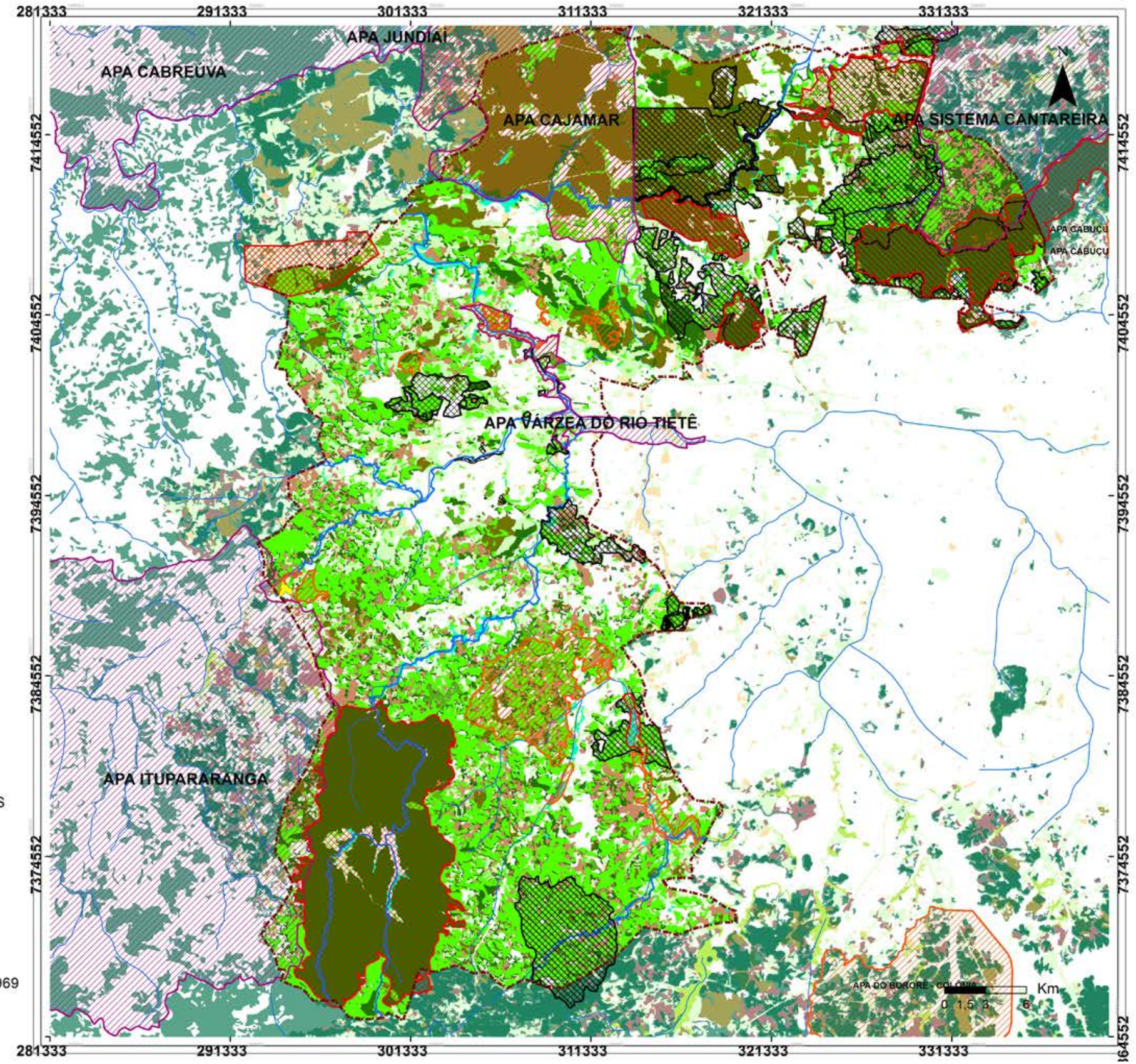




\subsubsection{UNIDADES DA PAISAGEM DE SEGUNDA ORDEM}

Em seguida procuramos definir as Unidades de $2^{\mathrm{a}}$. Ordem, ou seja, buscamos encontrar as Unidades da Paisagem finais. Nesta etapa do trabalho as Unidades da Paisagem I foram cruzadas com as informações sobre a Vegetação (suas 5 classes). Reinterpretamos as Unidades de 2 $2^{\text {a }}$. Ordem e com isso obtivemos as 55 Unidades da Paisagem final. O material obtido pelo cruzamento pode ser visualizado na Tabela 15 a seguir. Não apresentaremos o mapa referente as 55 unidades pela dificuldade de visualização de uma legenda tão extensa. O mais importante desta análise para as etapas subseqüentes é a matriz em formato de tabela que contem as informações de todas as analises realizadas, de todas as unidades obtidas, que poderão ser reagrupadas de acordo com a intenção. A tabela a seguir é apresentada com a interpretação do valor ecológico da paisagem, e colorida diferente para cada um dos 5 valores definidos. Cada uma das Unidades Paisagem foi avaliada em relação a alguns aspectos, para que pudéssemos obter a informação final sobre o Valor Ecológico da Paisagem Natural, como está mais bem descrito no item a seguir:

TABELA 15 - As 55 Unidades da Paisagem encontradas na área estudada e agrupadas por seu valor ecológico:Verde -Muito Alto (5) ;Verde Claro Alto (4) ; Amarelo -Médio (3); Azul Claro -Fraco (2); Azul Escuro -Muito Fraco (1).

\begin{tabular}{|c|c|c|c|c|c|c|c|}
\hline UNID. PAISAGEM & 1- MATA & 2- CAPOEIRA & $\begin{array}{c}\text { 3-REFLORES- } \\
\text { TAMENTO }\end{array}$ & $\begin{array}{c}\text { 4-CHÁCARA } \\
\text { CAMPO }\end{array}$ & $\begin{array}{c}\text { 5-VEGETAÇÃO } \\
\text { VÁRZEA }\end{array}$ & $\begin{array}{l}\text { 6- SOLO } \\
\text { EXPOSTO }\end{array}$ & $\begin{array}{c}\text { AREAS } \\
\text { URBANIZADOS }\end{array}$ \\
\hline 1 & $\begin{array}{l}1.1 \text { matas, } \\
\text { litologias moles, } \\
\text { sedimentos } \\
\text { arenosos e } \\
\text { planices aluviais, } \\
\text { permeaveis, } \\
\text { sem risco de } \\
\text { deslizamentos, } \\
\text { risco de } \\
\text { inundações. }\end{array}$ & $\begin{array}{l}\text { 1.2capoeiras, } \\
\text { litologias moles, } \\
\text { sedimentos arenosos } \\
\text { e planices aluviais, } \\
\text { permeaveis, } \\
\text { sem risco de } \\
\text { deslizamentos, risco } \\
\text { de inundações. }\end{array}$ & $\begin{array}{l}1.3 \text { reflorest } \\
\text { litologias moles, } \\
\text { sedimentos arenosos } \\
\text { e planices aluviais, } \\
\text { permeaveis, } \\
\text { sem risco de } \\
\text { deslizamentos, risco } \\
\text { de inundações. }\end{array}$ & $\begin{array}{l}1.4 \text { campo e } \\
\text { chacaras, litologias } \\
\text { moles, sedimen- } \\
\text { tos arenosos e } \\
\text { planices aluviais, } \\
\text { permeaveis, sem } \\
\text { risco de desliza- } \\
\text { mentos, risco de } \\
\text { inundaçôes. }\end{array}$ & $\begin{array}{l}1.5 \text { varz, litologias } \\
\text { moles , sedimentos } \\
\text { arenosos e planices } \\
\text { aluviais, permeaveis, } \\
\text { sem risco de desli- } \\
\text { zamentos, risco de } \\
\text { inundações. }\end{array}$ & $\begin{array}{l}1.6 \text { solo exp, lito- } \\
\text { logias moles, sedi- } \\
\text { mentos arenosos } \\
\text { e planices aluviais, } \\
\text { permeaveis, sem } \\
\text { risco de desliza- } \\
\text { mentos, risco de } \\
\text { inundações. }\end{array}$ & $\begin{array}{l}\text { litologias moles, sed- } \\
\text { imentos arenosos } \\
\text { e planices aluviais, } \\
\text { permeaveis, sem } \\
\text { risco de desliza- } \\
\text { mentos, risco de } \\
\text { inundações. }\end{array}$ \\
\hline 2 & $\begin{array}{l}2.1 \text { matas lito- } \\
\text { logias moles em } \\
\text { terraços fluviais } \\
\text { baixos, terraços e } \\
\text { encosta leves de } \\
\text { vales, permea- } \\
\text { bilidade media, } \\
\text { baixa tendência a } \\
\text { deslizamentos. }\end{array}$ & $\begin{array}{l}2.2 \text { capoeiras } \\
\text { litologias moles } \\
\text { em terraços fluviais } \\
\text { baixos, terraços e } \\
\text { encosta leves de } \\
\text { vales, permeabili- } \\
\text { dade media, baixa } \\
\text { tendência a desliza- } \\
\text { mentos }\end{array}$ & $\begin{array}{l}2.3 \text { reflorest, } \\
\text { litologias moles } \\
\text { em terraços fluviais } \\
\text { baixos, terraços e } \\
\text { encosta leves de } \\
\text { vales, permeabili- } \\
\text { dade media, baixa } \\
\text { tendência a desliza- } \\
\text { mentos. }\end{array}$ & $\begin{array}{l}2.4 \text { campo e } \\
\text { chacaras, lito- } \\
\text { logias moles em } \\
\text { terraços fluviais } \\
\text { baixos, terraços e } \\
\text { encosta leves de } \\
\text { vales, permea- } \\
\text { bilidade media, } \\
\text { baixa tendência a } \\
\text { deslizamentos }\end{array}$ & $\begin{array}{l}2.5 \text { varz litologias } \\
\text { moles em terraços } \\
\text { fluviais baixos, } \\
\text { terraços e encosta } \\
\text { leves de vales, per- } \\
\text { meabilidade media, } \\
\text { baixa tendência a } \\
\text { deslizamentos. }\end{array}$ & $\begin{array}{l}2.6 \text { solo exp } \\
\text { litologias moles } \\
\text { em terraços fluviais } \\
\text { baixos, terraços e } \\
\text { encosta leves de } \\
\text { vales, permeabili- } \\
\text { dade media, baixa } \\
\text { tendência a desliza- } \\
\text { mentos }\end{array}$ & $\begin{array}{l}\text { litologias moles } \\
\text { em terraços } \\
\text { fluviais baixos, } \\
\text { terraços e encosta } \\
\text { leves de vales, } \\
\text { permeabilidade } \\
\text { media, baixa } \\
\text { tendência a desli- } \\
\text { zamentos. }\end{array}$ \\
\hline
\end{tabular}




\begin{tabular}{|c|c|c|c|c|c|c|c|}
\hline UNID. PAISAGEM & 1- MATA & 2- CAPOEIRA & $\begin{array}{l}\text { 3-REFLORES- } \\
\text { TAMENTO }\end{array}$ & $\begin{array}{l}\text { 4-CHÁCARA } \\
\text { CAMPO }\end{array}$ & $\begin{array}{l}\text { 5-VEGETACCÃO } \\
\text { VÁRZEA }\end{array}$ & $\begin{array}{l}\text { 6- SOLO } \\
\text { EXPOSTO }\end{array}$ & $\begin{array}{c}\text { AREAS } \\
\text { URBANIZADOS }\end{array}$ \\
\hline 3 & $\begin{array}{l}3.1 \text { matas, litologias } \\
\text { duras e per- } \\
\text { meabilidade baixa } \\
\text { (vulcanosediment, } \\
\text { gnaisses e granitos, } \\
\text { maior estabilidade, } \\
\text { em planices inun- } \\
\text { daveis. }\end{array}$ & $\begin{array}{l}3.2 \text { capoeiras, } \\
\text { litologias duras e } \\
\text { permeabilidade baixa } \\
\text { (vulcanosediment, } \\
\text { gnaisses e granitos, } \\
\text { maior estabilidade, } \\
\text { em planices inun- } \\
\text { daveis. }\end{array}$ & $\begin{array}{l}3.3 \text { reflorest, } \\
\text { litologias duras e } \\
\text { permeabilidade baixa } \\
\text { (vulcanosediment, } \\
\text { gnaisses e granitos, } \\
\text { maior estabilidade, } \\
\text { em planices inun- } \\
\text { daveis. }\end{array}$ & $\begin{array}{l}3.4 \text { campo e chaca- } \\
\text { ras, litologias duras } \\
\text { e permeabilidade } \\
\text { baixa (vulcano- } \\
\text { sediment, gnaisses } \\
\text { e granitos, maior } \\
\text { estabilidade, em } \\
\text { planices inundaveis. }\end{array}$ & $\begin{array}{l}3.5 \text { varz, litologias } \\
\text { duras e permeabili- } \\
\text { dade baixa (vulcano- } \\
\text { sediment, gnaisses e } \\
\text { granitos, maior esta- } \\
\text { bilidade, em planices } \\
\text { inundaveis. }\end{array}$ & $\begin{array}{l}3.6 \text { solo exp lito- } \\
\text { logias duras e per- } \\
\text { meabilidade baixa } \\
\text { (vulcanosediment, } \\
\text { gnaisses e granitos, } \\
\text { maior estabilidade, } \\
\text { em planices inun- } \\
\text { daveis. }\end{array}$ & $\begin{array}{l}3 \text { litologias duras } \\
\text { e permeabilidade } \\
\text { baixa (vulcano- } \\
\text { sediment, gnaisses } \\
\text { e granitos, maior } \\
\text { estabilidade, em } \\
\text { planices inundaveis. }\end{array}$ \\
\hline 4 & $\begin{array}{l}4.1 \text { mata litologias } \\
\text { duras e impermeaveis } \\
\text { (vulcanosediment, } \\
\text { gnaisses e granitos, } \\
\text { maior estabilidade, } \\
\text { terraços fluviais } \\
\text { baixos, terraços e } \\
\text { encosta leves devales, } \\
\text { encostas suaves de } \\
\text { colinas morros } \\
\text { e serras, permea- } \\
\text { bilidade baixa, baixa } \\
\text { tendência a desliza- } \\
\text { mentos }\end{array}$ & $\begin{array}{l}4.2 \text { capoeiras, } \\
\text { litologias duras } \\
\text { e impermeaveis } \\
\text { (vulcanosediment, } \\
\text { gnaisses e granitos, } \\
\text { maior estabilidade, } \\
\text { terraços fluviais } \\
\text { baixos, terraços } \\
\text { e encosta leves } \\
\text { de vales, encostas } \\
\text { suaves de colinas } \\
\text { morros e serras, } \\
\text { permeabilidade } \\
\text { baixa, baixa tendên- } \\
\text { cia a deslizamentos. }\end{array}$ & $\begin{array}{l}4.3 \text { reflorest } \\
\text { litologias duras } \\
\text { e impermeaveis } \\
\text { (vulcanosediment, } \\
\text { gnaisses e granitos, } \\
\text { maior estabilidade, } \\
\text { terraços fluviais } \\
\text { baixos, terraços } \\
\text { e encosta leves } \\
\text { de vales, encostas } \\
\text { suaves de colinas } \\
\text { morros e serras, } \\
\text { permeabilidade } \\
\text { baixa, baixa tendên- } \\
\text { cia a deslizamentos. }\end{array}$ & $\begin{array}{l}4.4 \text { campo e chaca- } \\
\text { ras litologias duras e } \\
\text { impermeaveis (vulca- } \\
\text { nosediment, gnaisses e } \\
\text { granitos, maior esta- } \\
\text { bilidade, terraços flu- } \\
\text { viais baixos, terraços } \\
\text { e encosta leves de } \\
\text { vales, encostas suaves } \\
\text { de colinas morros e } \\
\text { serras, permeabilidade } \\
\text { baixa, baixa tendência } \\
\text { a deslizamentos. }\end{array}$ & $\begin{array}{l}4.5 \text { varz, litologias } \\
\text { duras e impermeaveis } \\
\text { (vulcanosediment, } \\
\text { gnaisses e granitos, } \\
\text { maior estabilidade, } \\
\text { terraços fluviais } \\
\text { baixos, terraços e } \\
\text { encosta leves de } \\
\text { vales, encostas suaves } \\
\text { de colinas morros e } \\
\text { serras, permeabilidade } \\
\text { baixa, baixa tendência } \\
\text { a deslizamentos. }\end{array}$ & $\begin{array}{l}4.6 \text { solo exp } \\
\text { litologias duras } \\
\text { e impermeaveis } \\
\text { (vulcanosediment, } \\
\text { gnaisses e granitos, } \\
\text { maior estabilidade, } \\
\text { terraços fluviais } \\
\text { baixos, terraços } \\
\text { e encosta leves } \\
\text { de vales, encostas } \\
\text { suaves de coli- } \\
\text { nas morros e } \\
\text { serras, permea- } \\
\text { bilidade baixa, } \\
\text { baixa tendência a } \\
\text { deslizamentos. }\end{array}$ & $\begin{array}{l}4 \text { litologias duras } \\
\text { e impermeaveis } \\
\text { (vulcanosediment, } \\
\text { gnaisses e granitos } \\
\text { maior estabi- } \\
\text { lidade, terraços- } \\
\text { fluviais baixos, } \\
\text { terraços e encosta } \\
\text { leves de vales, } \\
\text { encostas suaves } \\
\text { de colinas morros } \\
\text { e serras, permea- } \\
\text { bilidade baixa, } \\
\text { baixa tendência } \\
\text { a deslizamentos. }\end{array}$ \\
\hline 5 & $\begin{array}{l}5.1 \text { matas } \\
\text { litologias duras } \\
\text { e impermeaveis } \\
\text { (vulcanosediment, } \\
\text { gnaisses e granitos, } \\
\text { maior estabilidade, } \\
\text { encostas médias } \\
\text { de colinas, morros } \\
\text { e serras. Permeabi- } \\
\text { lidade baixa, } \\
\text { media tendência } \\
\text { a deslizamentos }\end{array}$ & $\begin{array}{l}5.2 \text { capoeiras, } \\
\text { litologias duras } \\
\text { e impermeaveis } \\
\text { (vulcanosediment, } \\
\text { gnaisses e granitos, } \\
\text { maior estabilidade, } \\
\text { encostas médias de } \\
\text { colinas, morros e } \\
\text { serras. permeabili- } \\
\text { dade baixa, media } \\
\text { tendencia a desliza- } \\
\text { mentos }\end{array}$ & $\begin{array}{l}5.3 \text { reflorest } \\
\text { litologias duras e } \\
\text { impermeaveis (vulca- } \\
\text { nosediment, gnaisses } \\
\text { e granitos, maior } \\
\text { estabilidade, encostas } \\
\text { médias de colinas, } \\
\text { morros e serras. } \\
\text { permeabilidade baixa, } \\
\text { media tendência a } \\
\text { deslizamentos }\end{array}$ & $\begin{array}{l}5.4 \text { campo e chácar- } \\
\text { as, litologias duras } \\
\text { e impermeaveis } \\
\text { (vulcanosediment, } \\
\text { gnaisses e granitos, } \\
\text { maior estabilidade, } \\
\text { encostas médias de } \\
\text { colinas, morros e } \\
\text { serras. permeabili- } \\
\text { dade baixa, media } \\
\text { tendência a desliza- } \\
\text { mentos }\end{array}$ & $\mathrm{X}$ & $\begin{array}{l}5.6 \text { solo exp } \\
\text { litologias duras } \\
\text { e impermeaveis } \\
\text { (vulcanosediment, } \\
\text { gnaisses e granitos } \\
\text { maior estabi- } \\
\text { lidade, encostas } \\
\text { médias de colinas, } \\
\text { morros e serras. } \\
\text { permeabilidade } \\
\text { baixa, media } \\
\text { tendência a desli- } \\
\text { zamentos }\end{array}$ & $\begin{array}{l}5 \text { litologias duras } \\
\text { e impermeaveis } \\
\text { (vulcanosediment, } \\
\text { gnaisses e granitos } \\
\text {, maior estabi- } \\
\text { lidade, encostas } \\
\text { médias de colinas, } \\
\text { morros e serras. } \\
\text { permeabilidade } \\
\text { baixa, media } \\
\text { tendência a desli- } \\
\text { zamentos }\end{array}$ \\
\hline 6 & $\begin{array}{l}6.1 \text { matas litologias } \\
\text { moles, sedimentos } \\
\text { arenosos e planices } \\
\text { aluviais, permea- } \\
\text { bilidade medias, } \\
\text { encostas suaves e } \\
\text { médias de colinas, } \\
\text { morros e serras. } \\
\text { alto risco de desli- } \\
\text { zamentos }\end{array}$ & $\begin{array}{l}6.2 \text { capoeiras } \\
\text { litologias moles, } \\
\text { sedimentos } \\
\text { arenosos e planices } \\
\text { aluviais, permea- } \\
\text { bilidade medias, } \\
\text { encostas suaves e } \\
\text { médias de colinas, } \\
\text { morros e serras. } \\
\text { alto risco de } \\
\text { deslizamentos }\end{array}$ & $\begin{array}{l}6.3 \text { reflorest } \\
\text { litologias moles, } \\
\text { sedimentos arenosos } \\
\text { e planices aluviais, } \\
\text { permeabilidade me- } \\
\text { dias, encostas suaves } \\
\text { e médias de colinas, } \\
\text { morros e serras. alto } \\
\text { risco de deslizamen- } \\
\text { tos. }\end{array}$ & $\begin{array}{l}\text { 6.4 campo } \\
\text { e chacaras, litologias } \\
\text { moles, sedimentos } \\
\text { arenosos e planices } \\
\text { aluviais, permeabili- } \\
\text { dade medias, encos- } \\
\text { tas suaves e médias } \\
\text { de colinas, morros e } \\
\text { serras. alto risco de } \\
\text { deslizamentos. }\end{array}$ & $\mathrm{X}$ & 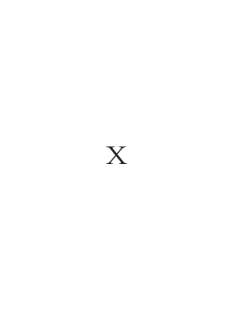 & $\begin{array}{l}6 \text { litologias moles, } \\
\text { sedimentos areno- } \\
\text { sos e planices } \\
\text { aluviais, permea- } \\
\text { bilidade medias, } \\
\text { encostas suaves e } \\
\text { médias de colinas, } \\
\text { morros e serras. } \\
\text { alto risco de desli- } \\
\text { zamentos. }\end{array}$ \\
\hline
\end{tabular}




\begin{tabular}{|c|c|c|c|c|c|c|c|}
\hline UNID. PAISAGEM & 1- MATA & 2- CAPOEIRA & $\begin{array}{l}\text { 3-REFLORES- } \\
\text { TAMENTO }\end{array}$ & $\begin{array}{c}\text { 4-CHÁCARA } \\
\text { CAMPO }\end{array}$ & $\begin{array}{l}\text { 5-VEGETACCÃO } \\
\text { VÁRZEA }\end{array}$ & $\begin{array}{l}\text { 6- SOLO } \\
\text { EXPOSTO }\end{array}$ & $\begin{array}{c}\text { AREAS } \\
\text { URBANIZADOS }\end{array}$ \\
\hline 7 & $\begin{array}{l}7.1 \text { matas litolo- } \\
\text { gias moles , sedi- } \\
\text { mentos arenosos } \\
\text { e planices aluviais, } \\
\text { permeabilidade } \\
\text { medias, alto risco } \\
\text { de deslizamentos } \\
\text { encost erosiv tran- } \\
\text { sic vales e encost } \\
\text { acentua morr e } \\
\text { serr. }\end{array}$ & $\begin{array}{l}7.2 \text { capoeiras, } \\
\text { litologias moles } \\
\text {, sedimentos } \\
\text { arenosos e planices } \\
\text { aluviais, permeabi- } \\
\text { lidade medias, alto } \\
\text { risco de desliza- } \\
\text { mentos encost } \\
\text { erosiv transic vales } \\
\text { e encost acentua } \\
\text { morr e serr. }\end{array}$ & $\begin{array}{l}7.3 \text { reflorest } \\
\text { litologias moles }, \\
\text { sedimentos arenosos } \\
\text { e planices aluviais, } \\
\text { permeabilidade } \\
\text { medias, alto risco } \\
\text { de deslizamentos } \\
\text { encost erosiv transic } \\
\text { vales e encost } \\
\text { acentua morr serr. }\end{array}$ & $\begin{array}{l}7.4 \text { campo e } \\
\text { chacaras litologias } \\
\text { moles, sedimen- } \\
\text { tos arenosos e } \\
\text { planices aluviais, } \\
\text { permeabilidade } \\
\text { medias, alto risco } \\
\text { de deslizamen- } \\
\text { tos encost erosiv } \\
\text { transic vales e } \\
\text { encost acentua } \\
\text { morr e serr. }\end{array}$ & $\mathrm{x}$ & $\begin{array}{l}\text { 7.6 solo exp litolo- } \\
\text { gias moles , sedi- } \\
\text { mentos arenosos } \\
\text { e planices aluviais, } \\
\text { permeabilidade } \\
\text { medias, alto risco } \\
\text { de deslizamentos } \\
\text { encost erosiv tran- } \\
\text { sic vales e encost } \\
\text { acentua morr e }\end{array}$ & $\begin{array}{l}7 \text { litologias moles } \\
\text {, sedimentos } \\
\text { arenosos e planices } \\
\text { aluviais, permeabi- } \\
\text { lidade medias, alto } \\
\text { risco de desliza- } \\
\text { mentos encost } \\
\text { erosiv transic vales } \\
\text { e encost acentua } \\
\text { morr e serr. }\end{array}$ \\
\hline 8 & $\begin{array}{l}8.1 \text { matas litolo- } \\
\text { gias duras e muito } \\
\text { baixa permeabi- } \\
\text { lidade (vulcano- } \\
\text { sediment, gnaisses } \\
\text { e granitos) encost } \\
\text { erosiv transic vales } \\
\text { e encost acentua } \\
\text { morr e serr - risco } \\
\text { deslizamnetos. }\end{array}$ & $\begin{array}{l}8.2 \text { matas litolo- } \\
\text { gias duras e muito } \\
\text { baixa permeabi- } \\
\text { lidade (vulcano- } \\
\text { sediment, gnaisses } \\
\text { e granitos) encost } \\
\text { erosiv transic vales } \\
\text { e encost acentua } \\
\text { morr e serr - risco } \\
\text { deslizamnetos. }\end{array}$ & $\begin{array}{l}8.3 \text { reflorest litolo- } \\
\text { gias duras e muito } \\
\text { baixa permea- } \\
\text { bilidade (vulcano- } \\
\text { sediment, gnaisses } \\
\text { e granitos) encost } \\
\text { erosiv transic vales } \\
\text { e encost acentua } \\
\text { morr e serr - risco } \\
\text { deslizamnetos. }\end{array}$ & $\begin{array}{l}8.4 \text { campo e } \\
\text { chacaras, litolo- } \\
\text { gias duras e muito } \\
\text { baixa permeabi- } \\
\text { lidade (vulcano- } \\
\text { sediment, gnaisses } \\
\text { e granitos) encost } \\
\text { erosiv transic } \\
\text { vales e encost } \\
\text { acentua morr e } \\
\text { serr - risco desli- } \\
\text { zamnetos. }\end{array}$ & $\begin{array}{l}8.5 \text { varz, litologias } \\
\text { duras e muito } \\
\text { baixa permeabi- } \\
\text { lidade (vulcano- } \\
\text { sediment, gnaisses } \\
\text { e granitos) encost } \\
\text { erosiv transic vales } \\
\text { e encost acentua } \\
\text { morr e serr - risco } \\
\text { deslizamentos }\end{array}$ & $\begin{array}{l}8.6 \text { solo exp litolo- } \\
\text { gias duras e muito } \\
\text { baixa permeabi- } \\
\text { lidade (vulcano- } \\
\text { sediment, gnaisses } \\
\text { e granitos) encost } \\
\text { erosiv transic vales } \\
\text { e encost acentua } \\
\text { morr e serr - risco } \\
\text { deslizamnetos. }\end{array}$ & $\begin{array}{l}8 \text { litologias duras } \\
\text { e muito baixa } \\
\text { permeabilidade } \\
\text { (vulcanosedi- } \\
\text { ment, gnaisses e } \\
\text { granitos) encost } \\
\text { erosiv transic vales } \\
\text { e encost acentua } \\
\text { morr e serr - risco } \\
\text { deslizamnetos. }\end{array}$ \\
\hline \multirow[b]{2}{*}{9} & $\begin{array}{l}9.1 \text { matas topos de } \\
\text { morros agrupados. }\end{array}$ & $\begin{array}{l}9.2 \text { capoeiras, } \\
\text { topos de morros } \\
\text { agrupados. }\end{array}$ & $\begin{array}{l}9.3 \text { reflorest topos } \\
\text { de morros agrupa- } \\
\text { dos. }\end{array}$ & $\begin{array}{l}9.4 \text { campo e } \\
\text { chacaras, topos } \\
\text { de morros agru- } \\
\text { pados. }\end{array}$ & $\begin{array}{l}9.5 \text { varz topos de } \\
\text { morros agrupados. }\end{array}$ & $\begin{array}{l}9.6 \text { solo exp topos } \\
\text { de morros agru- } \\
\text { pados. }\end{array}$ & $\begin{array}{l}9 \text { topos de morros } \\
\text { agrupados }\end{array}$ \\
\hline & & & & & & & \\
\hline
\end{tabular}




\subsection{AVALIACAO DAS ÁREAS PASSÍVEIS DE TEREMSEU VALOR ECOLÓGICO CONSERVADO OU RECUPERADO}

As 55 unidades da paisagem encontradas foram reorganizadas buscando verificar aquelas que possuem potencial para preservação, conservação e recuperação, e assim seriam áreas componentes da proposta dos corredores verdes. As áreas que possuem tal potencial são as áreas detentoras de valor ecológico em conjunto com as áreas vulneráveis a riscos, portanto não indicadas a todas as atividades humanas, especialmente a ocupação por cidades. Entendemos que as áreas com valor ecológico alto e muito alto são aquelas que abrigam uma vegetação desenvolvida, de matas, capoeira, vegetação de várzea e reflorestamento, alem de todas as áreas do sistema úmido as quais são de grande importância para a dinâmica ecológica do sistema hídrico da paisagem, e as áreas com litologias porosas em áreas baixas e planas, que acabam por permitir a absorção de águas pluviais e as recargas dos aqüíferos. As áreas vulneráveis a riscos e acidentes são as com litologia porosa em altas declividades (suceptiveis a deslizamentos), com litologias duras em áreas úmidas (áreas inundáveis), e os topos de morros. A sobreposição de tais condições tornam as áreas com valores ecológicos ainda mais altos.

Com base nas Unidades da Paisagem obtidas e seus processos e comportamentos tentamos definir o potencial das áreas para conservação e recuperação com relação a alguns aspectos:

1.Integridade da Vegetação

2.Manutenção Sistema Úmido

3.Permeabilidade do Solo

4.Instabilidade Relevo

5.Erodibilidade Solo

6.Declividade

A grande importância em se buscar incluir o valor ecológico da paisagem natural é que este representa um dos fatores condicionantes do seu potencial de conservação e recomposição da vegetação e de percolação da água sobre solos porosos e sua vulnerabilidade em relação aos riscos de erosão e inundações. Dessa forma, áreas com alto valor ecológico são aquelas que se encontram em porções da paisagem natural que guardam uma vegetação com alta integridade, área de reserva 
e recarga de aqüíferos e se localizam no sistema úmido da paisagem.

Com os critérios acima explicitados as 55 unidades da paisagem obtidas nas etapas anteriores foram interpretadas em cinco ordens de valor ecológico: Muito Alto, com coloração Verde Escuro; Alto, com coloração Verde Claro; Médio, amarelo; Baixo, azul claro e Muito Baixo colorido com azul escuro. (Tabela 15 acima e Mapa 20).

Indicado pela composição das áreas de Valor Ecológico Alto e Muito Alto foi possível traçar um desenho, numa escala regional, ou seja, macro, de um sistema de corredores ecológicos, composto por áreas contínuas e/ou próximas que possuem valores ecológicos para a paisagem. As áreas com classe de Valor Ecológico Médio foram melhor estudadas no próximos capítulo, em situações locais, e que serão agregadas ou não ao sistema dependendo do contexto local.

A vulnerabilidade das unidades a inundações e deslizamentos foi analisada para as áreas que apresentaram um valor ecológico baixo e muito baixo, ou seja que seguindo o raciocínio utilizado as mesma não iriam ser incluídas no sistema de corredores. Verificamos nas Unidades da Paisagem 1; 3; 6; 7; 8; 6.4; 8.4 e 8.6 características que as tornam vulneráveis ou a inundações ou a deslizamentos. Algumas destas unidades são áreas urbanizadas e não entraram no escopo do trabalho outras são áreas com campo, chácaras e solo exposto, e que por apresentarem tais vulnerabilidades foram incluídas no desenho macro de corredores. O mapa das áreas com valor ecológico baixo e muito vulneráveis a inundação e deslizamentos esta apresentando a seguir.

O desenho do sistema macro de corredores obtido poderá ser visualizado no MAPA 22 a seguir. As áreas agrupadas formadores do desenho macro do sistema de corredores têm a coloração verde escuro. 
Pudemos constatar que as áreas com valor ecológico mais alto dentro da paisagem e que não estão ocupadas por áreas urbanas estão concentradas na borda externa do limite Oeste da área de abrangência. Algumas faixas radiais em direção ao centro da cidade de São Paulo também foram marcadas pro terem valores ecológicos altos.

A área total que o sistema macro de corredores ocupa é de aproximadamente $895 \mathrm{Km}^{2}$, o que representa aproximadamente $74 \%$ da área total da área de estudo.

Em uma macro escala obtivemos um desenho possível de um sistema de corredores que atravessaria a área de abrangência do estudo, e conectaria as 3 manchas de vegetação mais significativas, tanto em tamanho como em composição de flora: Serra da Cantareira, Morro Grande e Serra do Boturuna. A sua continuidade não é integral, com a presença de barreiras e conflitos, como rodovias e áreas urbanas, necessitando de alguns detalhes pontuais de projetos de corredores de forma que seria possível fazer a conexão dos fragmentos. Podemos afirmar também que este macro corredor ecológico regional, também garantiria a integridade da estrutura ecológica fundamental que ainda não foi ocupada por urbanização. $O$ desenho obtido desenho além de conseguir promover a conexão entre os fragmentos é capaz de manter as funções ecológicas (vegetação, rede hídrica, áreas inundáveis, áreas com riscos de deslizamentos e as áreas permeáveis) no trecho onde está inserido. 


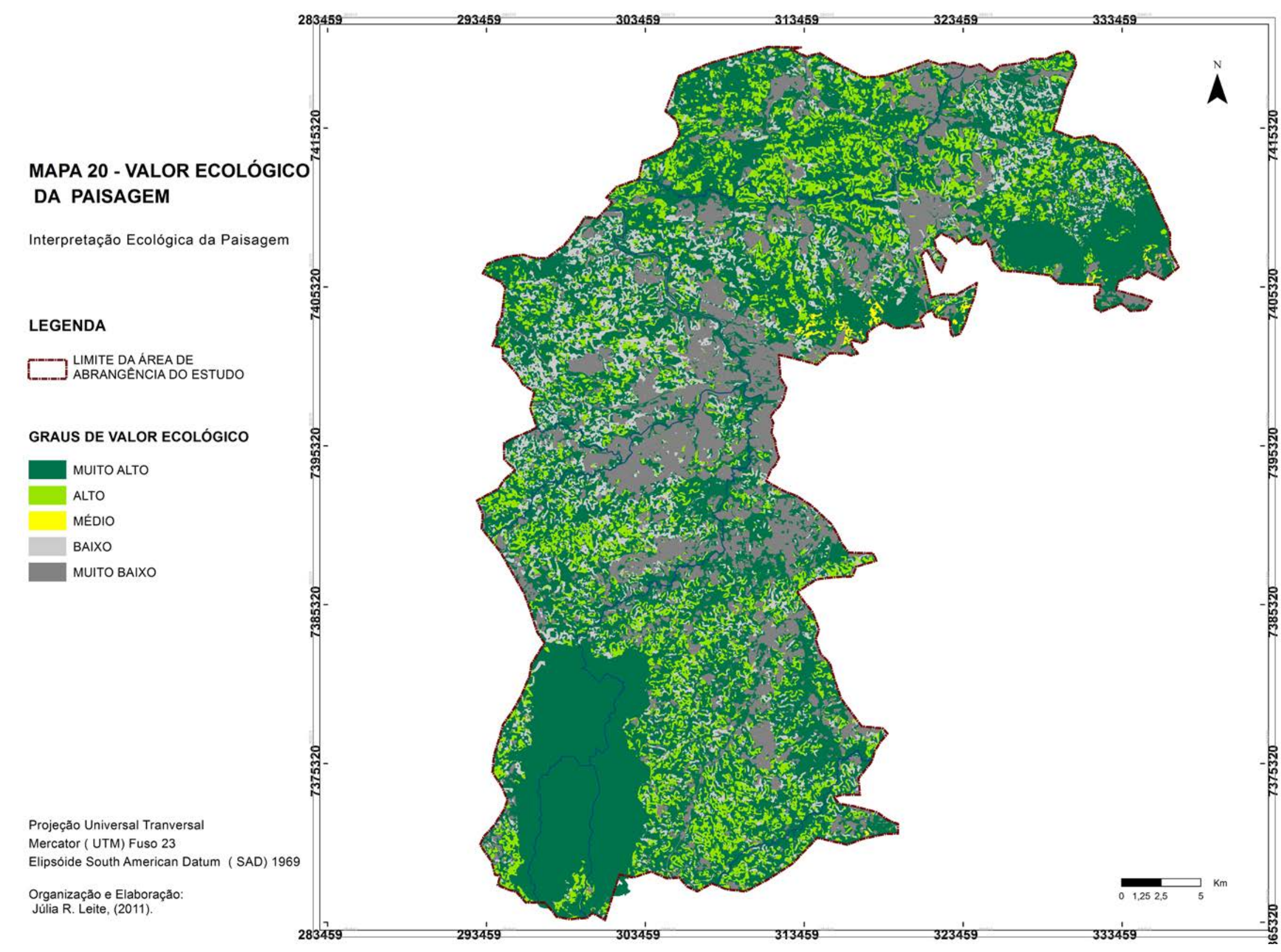


MAPA 21 - VALORES

ECOLÓGICOS BAIXO E

MUITO BAIXO VULNERÁVEIS

A DESLIZAMENTOS E

\section{INUNDAÇÔES}

Interpretação Ecológica da Paisagem

\section{LEGENDA}

LI...... LIMITE DAÁREA DE

LIMITE DAAREA DE
ABRANGENCIA DO ESTUDO

ÁREAS COM VULNERABILIDADEA DESLIZAMENTOS E INUNDAÇOES

AREAS COM URBANIZAÇAO CONSOLIDADA

ÁREAS COM SOLO EXPOSTO, DESOCUPADOS, CAMPOS E CHÁCARAS

Projeção Universal Tranversa Mercator ( UTM) Fuso 23

Elipsóide South American Datum ( SAD) 1969 Organizaçăo e Elaboração:

Júlia R. Leite, (2011).

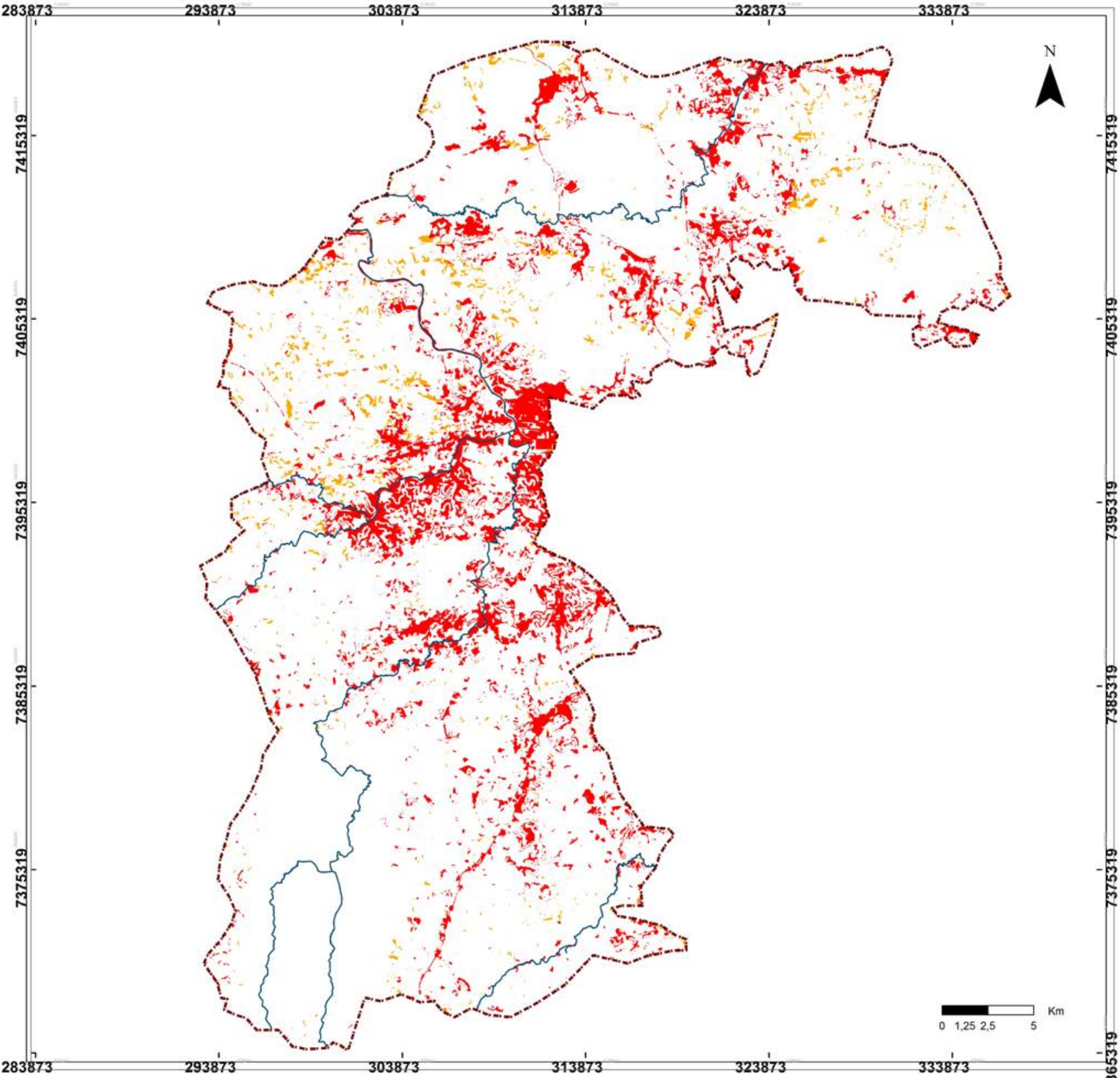


MAPA 22 - SISTEMA DE

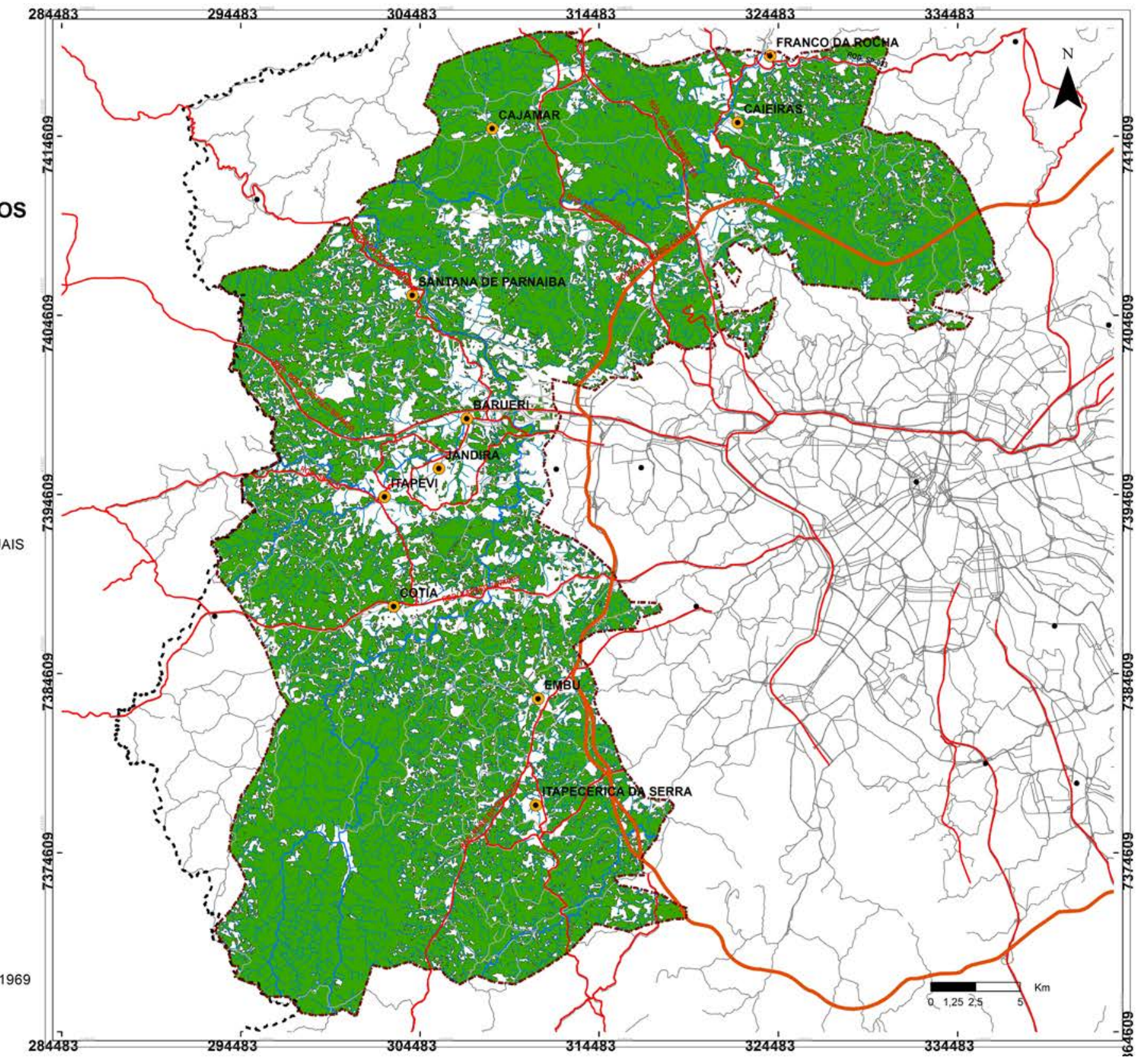

Projeção Universal Tranversal Mercator ( UTM) Fuso 23

Elipsoiide South American Datum ( SAD) 1969 Organizaçăo e Elaboração: 
As etapas e procedimentos realizados nos permitiu definir para a paisagem estudada, dentro de seus elementos naturais, o que do território ainda contem de áreas com elementos com potencial para serem preservados, conservados e até mesmo serem recuperados, desta forma sugerimos receber atenção para ações e medidas de conservação e proteção da natureza.

Os processo urbanos e administrativos identificados foram excluídos desta análise por se tratar de uma complexa abordagem que esta fora do escopo deste trabalho. Remover centros urbanos, empreendimentos e loteamentos, rever políticas publicas de desenvolvimento urbano, habitação, sistema de transportes não se trata de uma tarefa fácil, portanto mesmo todos esses processos ocorrerem dentro dos limites da RBCV e muitas deles se darem nas áreas da paisagem natural classificadas neste estudo com fragilidade muito alta e alta, tais situações precisam ser tratadas individualmente e sob outro enfoque. As áreas não urbanizadas são, portanto as que mereceram atenção e correspondem a possibilidades para a implantação de corredores ecológicos, compostos de vários espaços abertos multifuncionais conectados, os quais podem assumir várias tipologias, integrando uma proposta de Infraestrutura Verde para região.

A principal contribuição desta etapa foi abrir a possibilidade de começarmos a esboçar os sentidos e abrangências dos respectivos vetores de conexão, o que vai nos permitir um seu posterior aprofundamento já na escala de uma plano diretor (master plan), com indicação das diversas ações localizadas que devem ser traduzidas em projetos de arquitetura da paisagem específicos, para que possa ser finalmente demonstrada a viabilidade de resolução de conflitos e interesses divergentes de uso do solo. 
DELINEAMENTO DAS FAIXAS DE ESTUDO PARA A VERIFICAÇÃO DA IMPLEMENTAÇÃO DO SISTEMA DE CORREDORES ECOLÓGICOS 


\section{CAPÍTULO 4 \\ DELINEAMENTO DAS FAIXAS \\ DE ESTUDO PARA A VERIFICAÇÃO \\ DA IMPLEMENTAÇÃO DO SISTEMA DE CORREDORES ECOLÓGICOS}

Neste capítulo, continuamos a apresentar os resultados da análise da paisagem, mas agora procuramos sintetizar e interpretar as informações obtidas, de modo a delinear faixas em que os corredores encontrariam maiores condições de desenvolvimento.

Selecionamos três trechos do eixo principal e duas faixas indicativas secundárias, considerando suas características (largura, composição e uso existente) e situação urbana. Realizamos então as últimas análises para observar as condições de implementação, de maneira que limites e bordas fossem ainda mais bem definidos e os conflitos mais evidenciados e discutidos. Além disso, elaboramos algumas possibilidades de implantação de soluções projetuais, capazes de minimizar esses conflitos e viabilizar um sistema integrado de corredores ecológicos em situações de intensa transformação.

\subsection{TRACADO DAS FAIXAS DE CORREDORES ECOLÓGICOS}

Tendo o sistema macro de corredores ecológicos como base, interpretamos graficamente as áreas detentoras de valores ecológicos alto e muito alto (definidas no capítulo 3), áreas com potencial de abrigo e condução de animais silvestres, sementes vegetais e preservação de fluxos hídricos. Com essa interpretação, 
e de forma a tornar a proposta mais compreensível, por meio de flechas, definimos um desenho para as bordas dos corredores e agregamos uma hierarquização gráfica das possibilidades de fluxos ecológicos, discutindo suas características, potencialidades, limitações e conflitos.

Assim, representamos graficamente faixas de corredores sobre as áreas, priorizando aquelas mais importantes para os fluxos ecológicos, de maneira a termos uma indicação da estrutura principal do sistema de corredores. Com esse desenho, identificamos o trecho de maior possibilidade de fluxos para animais e desenvolvimento da vegetação, o que justificaria a presença de um corredor principal, de caráter radial, com alguns trechos perpendiculares indo ao encontro das áreas mais urbanizadas. Estes últimos têm as faixas delimitadas por linhas mais finas, indicando que sua estrutura ecológica é menos rica que a principal.

Este desenho é apresentado no Mapa 23 a seguir. Buscamos, com esta representação, iniciar também a discussão sobre os conflitos causados por áreas urbanizadas e em expansão, e por barreiras provenientes, bem como sobre os riscos de acidentes à fauna devido à existência de rodovias na área estudada.

Uma marcação inicial da estrutura principal do corredor nos mostrou, por meio dos quadriláteros desenhados, que a conectividade dele é limitada; ou seja, não há possibilidade de termos hoje um corredor ecológico inteiramente contínuo na área estudada. No contorno envoltório de todos esses quadrados, obtivemos a representação das faixas indicativas de corredores ecológicos para a área, a faixa principal e as secundárias do sistema.

A tabela com as 55 unidades da paisagem encontradas na etapa anterior foi reinterpretada e obtivemos nove classes, cada uma representando uma importância para a condução de fluxos ecológicos; ou seja, com potencialidades distintas, capazes de direcionar, cada uma a seu modo, os fluxos sobre as faixas de corredores ecológicos. Apresentadas no item a seguir, essas classes serviram como base para o sentido dos fluxos ecológicos possíveis, mas não figuram no mesmo mapa para não dificultar a visualização das outras informações.

Como resultado, obtivemos os sentidos, representados por meio de vetores, que os corredores principais podem assumir, ainda de modo preliminar, numa tentativa de apreender o desempenho que tal sistema poderá ter para a condução de fluxos. Este desempenho foi aqui considerado apenas visualmente, pela largura da faixa do corredor, a distância entre os fragmentos, seu grau de importância, sua composição e a situação de entorno. Representamos essa diferenciação por meio de linhas e setas com espessuras, na cor amarela e com tamanhos distintos, de maneira a ilustrarmos a existência de condução e o seu potencial (Mapa 23). 


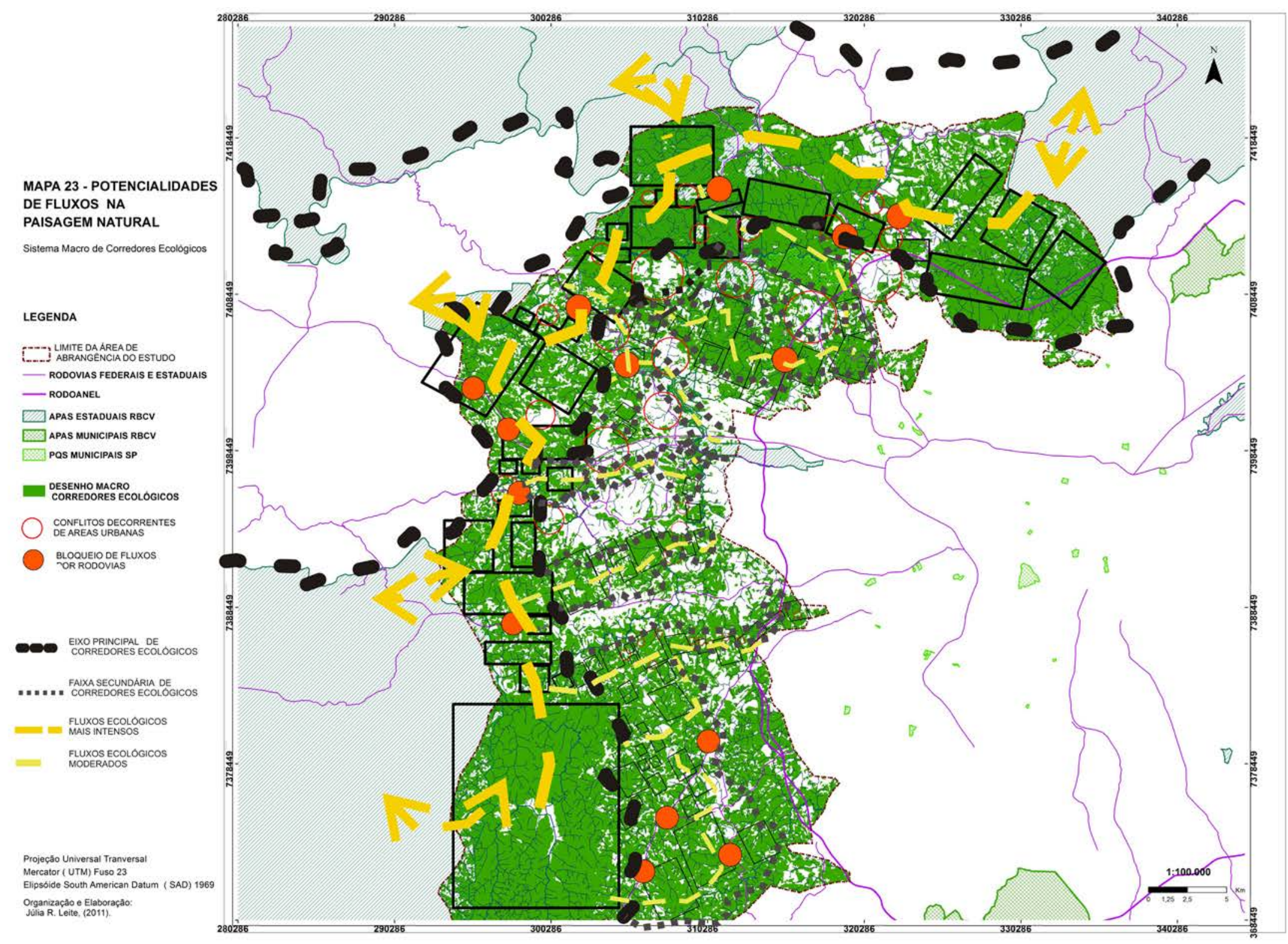




\subsubsection{CLASSES DE GRAUS DE IMPORTÂNCIA PARA A CONDUCÃ̃O DE FLUXOS ECOLÓGICOS}

Reinterpretamos as unidades da paisagem buscando hierarquizar os graus de importância ecológica para os processos ecológicos de fauna e flora (mobilidade, reprodução, abrigo, oferta de alimentos, proteção, dentre outros). Assim, definimos nove classes de importância, com suas cores correspondentes indicadas na legenda do mapa:

9 - Máxima Importância: matas, capoeiras e vegetação de várzea no sistema úmido (Verde Escuro);

8 - Grande Importância: matas, capoeiras e vegetação de várzea no sistema seco;

7 - Muito Alta Importância: vegetação de reflorestamento de eucalipto e pinheiros no sistema úmido (Verde Musgo Escuro);

6 - Alta Importância: vegetação de reflorestamento de eucalipto e pinheiros no sistema seco

(Verde Musgo Claro);

5 - Média Alta Importância: vegetação de campo e chácaras no sistema úmido (Verde Acinzentado);

4 - Média Importância: vegetação de campo e chácaras no sistema seco (Verde Amarelado);

3 - Média Baixa Importância: solo exposto sistema úmido (Rosa Claro);

2 - Baixa Importância I: solo exposto sistema seco (Beje Claro).

1 - Baixa Importância II: solos expostos vulneráveis (Capítulo 3)

0 - Baixa Importância III: áreas urbanizadas (Capítulo 2);

Como já dito, essa interpretação nos possibilitou uma base para o desenho das faixas indicativas de corredores ecológicos e para a caracterização e interpretação de suas condições, como pode ser visualizado nos mapas de cada faixa no item a seguir. 


\subsection{EIXO DO CORREDOR PRINCIPAL E SEUS EIXOS SECUNDÁRIOS}

O eixo principal, estruturador do sistema de corredores, conforma um corredor mais largo, que percorre toda a extensão norte-sul e foi ancorado nas três principais áreas de proteção incluídas na área de abrangência: Serra da Cantareira, Morro Boturuna e Morro Grande, sendo que elas tiveram apenas uma pequena parte incluída no eixo do corredor, como pode ser visto a seguir. Definimos a existência de cinco faixas secundárias, perpendiculares ao eixo principal, que alcançam a parte urbanizada da Região Metropolitana de São Paulo, sendo a quinta delas formada por uma volta (looping).

Os limites do eixo principal e dessas cinco faixas secundárias do sistema de corredores foram desenhados para que pudéssemos continuar a avaliação da paisagem natural. Buscamos caracterizar mais precisamente cada um dos eixos, discutir mais a situação e condição das áreas com valor ecológico muito alto, alto e médio, os conflitos existentes e refinar ainda mais o traçado das faixas verdes, no intuito de verificar a possibilidade de implementação de corredores ecológicos no trecho estudado.

Neste item, são apresentados os resultados dessa análise, por meio de mapas e discussão de dados, sobre os quais definimos as áreas de mais interesse para o sistema de corredores. Foram elaborados seis mapas, sendo cada um correspondente a um dos eixos dos corredores, de maneira a ilustrar melhor as condições atuais das áreas estudadas. As interpretações de uso do solo e dos conflitos foram feitas tendo como base as Unidades da Paisagem em conjunto com imagens do aplicativo Google Earth (2012), mais atuais que a base de dados usada (EMPLASA, 2006). Com essa interpretação, em muitas situações identificamos diferenças no uso do solo, como a presença de núcleos urbanos em áreas anteriormente não urbanizadas, especialmente sobre aquelas antes recobertas com solo exposto e campo.

No eixo principal, tanto as descrições dos conflitos como a apresentação das áreas de interesse foram mais bem detalhadas. Essa abordagem diferenciada ocorreu devido à sua maior importância no sistema, ao fato de estarem agregados, nesse eixo, valores ecológicos mais significativos da área estudada e também por conduzir os fluxos principais. 


\subsubsection{CONFLITOS E BARREIRAS}

Conflitos decorrentes de manchas urbanas dentro da área estudada foram destacados com círculos vermelhos indicando a sua localização. O grau de dificuldade de transposição de alguns conflitos foi verificado em algumas situações e em uma escala mais aproximada, de modo a contemplarmos mais informações e detalhes.

As barreiras e impactos provenientes do contato de rodovias com o sistema de corredores, marcados com círculos preenchidos com coloração laranja, geram dificuldades para alguns fluxos ecológicos. A principal solução para esse impacto sobre os animais e para a manutenção de trocas gênicas para a vegetação é a construção de túneis de travessias ou de pontes vegetadas, que servem como condutores de fluxos.

As rodovias são elementos lineares indispensáveis ao funcionamento das cidades para transporte de pessoas e cargas. A partir do final da década de 1960, houve a obrigatoriedade de se realizar Relatórios de Avaliação de Impactos Ambientais para a construção de estradas no Brasil ${ }^{39}$, os quais, mais recentemente, vêm incluindo em seus estudos medidas mitigadoras para os problemas relacionados a atropelamento de animais e passagem para fauna.

As estradas, dependendo do volume de tráfego e características associadas, representam barreiras ou filtros, aos movimentos diários de animais, a migração, a dispersão de indivíduos, e consequentemente ao intercâmbio genético, seja por meio da destruição do habitat, da morte por atropelamento ou pela repulsa do animal para atravessar (JAEGER et al., apud BAGER, 2011).

A ecologia de estradas é uma área de estudo recente, mais ligada à biologia, e enfatiza mais os impactos das rodovias sobre os vertebrados. Segundo Bager (2011), esse enfoque em atropelamentos da fauna é equivocado, e temos carência de trabalhos sobre efeitos marginais de rodovias, monitoramento de indivíduos por radiotelemetria, marcação e captura, entre outros que reflitam a densidade e o comportamento dos indivíduos no entorno da rodovia.

\subsubsection{EIXO PRINCIPAL}

O eixo principal do sistema de corredores possui uma área de $507 \mathrm{~km}^{2}$. Dentro dele estão contidos os maiores valores ecológicos encontrados no setor estudado (Mapa 24).

Alguns aspectos nos permitem inferir que existe maior fluxo de animais e de processos
${ }^{39}$ De acordo com a Resolução CONAMA $\mathrm{N}^{\circ}$ 001, de 23 de Janeiro de 1986. Publicado no Diário Oficial da União de $17 / 2 / 86$. Artigo $2^{\circ}$. Parágrafo I. 
ecológicos (de um modo geral) na área marcada. São eles: proximidade com unidades de conservação da natureza de grande extensão - Morro do Boturuna, Parque Estadual da Cantareira, Morro Grande, bem como com as APAS de Cajamar e Itupararanga, Parque Estadual da Serra do Mar, Serra de Paranapiacaba e APA Cantareira; presença de maior concentração de matas, também em estágios avançados, como as capoeiras; presença de fauna, também com espécies de graus moderados e altos de exigência ecológica.

A distância dos centros urbanos mais adensados priva tal trecho de conflitos decorrentes da interferência de circulação de veículos, poluição do ar, dejetos, ruídos, impermeabilização de solos, dentre outros, de modo que o eixo central consegue exercer bem seu papel como ecossistema e na manutenção de processos ecológicos.

Encontramos dez municípios no eixo central, que podem ser visualizados na tabela abaixo, contendo a área que ocupam e o percentual relacionado à área total do eixo. Destes, quatro ocupam 66\% da área - Santana de Parnaíba (21,64\%); Caieiras (18,07\%); Cajamar (15,89\%); Itapevi (10,37\%).

TABELA 16 - Municípios encontrados no eixo principal do Sistema de Corredores,

a área que ocupam e seus respectivos percentuais.

\begin{tabular}{l|l|l} 
MUNICÍPIOS & \multicolumn{2}{c}{ ÁREA KM } \\
BARUERI & 9,33 & $1,84 \%$ \\
\hline CAIEIRAS & 91,63 & $18,07 \%$ \\
\hline CAJAMAR & 80,58 & $15,89 \%$ \\
\hline COTIA & 38,37 & $7,57 \%$ \\
\hline FRANCO DA ROCHA & 41,91 & $8,27 \%$ \\
\hline ITAPEVI & 52,58 & $10,37 \%$ \\
\hline MAIRIPORÃ & 28,83 & $5,69 \%$ \\
\hline SANTANA DE PARNAIBA & 109,73 & $21,64 \%$ \\
\hline SÃO PAULO & 40,39 & $7,97 \%$ \\
\hline VARGEM GRANDE PAULISTA & 13,65 & $2,69 \%$ \\
\hline ÁREA TOTAL & $\mathbf{5 0 7 , 0 0}$ & $\mathbf{1 0 0 , 0 0 \%}$
\end{tabular}




\section{OPORTUNIDADES NO EIXO PRINCIPAL}

Como apresentado no Mapa 24 a seguir, o eixo principal possui recursos e elementos naturais que o tornam mantenedor de circulação biológica, bem como de recarga de aquíferos e do sistema úmido. Além do contato que mantém com áreas maiores de conservação, existem no sistema úmido 1715 fragmentos com matas, vegetação de várzea e capoeira (Classe 9), nenhum fragmento de vegetação de reflorestamento (Classe 7), três fragmentos chácaras e campo (Classe 5). Já no sistema seco, há 881 fragmentos de matas, vegetação de várzea e capoeira (Classe 8), 328 fragmentos de reflorestamento (Classe 6), 1447 fragmentos de chácaras e campo (Classe 4), nenhum fragmento de solo exposto (Classe 3) e, ainda, 184 fragmentos em áreas não urbanizadas vulneráveis (Classe 2). Foram excluídos desta análise os fragmentos com área inferior a $0.01 \mathrm{~km}^{2}$, considerados como residuais na escala abordada.

Os fragmentos maiores, classificados como Classes de Importância 9 e 8 e com área superior a $3 \mathrm{~km}^{2}$, estão concentrados na parte sul do eixo, exatamente no limite da reserva do Morro Grande. Também estão concentrados na parte norte e correspondem à vegetação do Parque Estadual da Cantareira, bem como às áreas incluídas na Zona Especial de Preservação Ambiental e Recursos Hídricos (ZEPARRH) do município de Caieiras e na Zona Especial de Proteção Ambiental no município de São Paulo. Os fragmentos médios, com área entre 0,5 e $3 \mathrm{~km}^{2}$, estão localizados em locais próximos às áreas de conservação e aos fragmentos maiores. Os fragmentos menores do que $0,5 \mathrm{~km}^{2}$ estão distribuídos ao longo de todo o eixo.

Já para a Classe de Importância 6, os fragmentos maiores do que $3 \mathrm{~km}^{2}$ estão concentrados mais especificamente na APA Cajamar, e os menores estão mais distribuídos, embora localizados ao norte do eixo.

A Classe de Importância 5 apresenta apenas três fragmentos no eixo central, todos com uma área inferior a $0,5 \mathrm{~km}^{2}$. Já para a Classe de Importância 4, os maiores fragmentos, entre 0,5 e $3 \mathrm{~km}^{2}$, concentram-se no centro do eixo, e os de áreas inferiores a $0,5 \mathrm{~km}^{2}$ distribuem-se ao longo do total.

Com relação às áreas protegidas por instrumentos legais, a maior parte do município de São Paulo presente no eixo principal é de áreas de proteção - Parque Estadual da Cantareira e Parque Municipal Anhanguera. Além destes, o eixo possui outros instrumentos de proteção que visam garantir a integridade dos ecossistemas e impedir alterações destes sítios: partes dos já referidos aqui, Morro Boturuna, Parque Estadual Cantareira, Morro Grande, Parque Estadual Juqueri, APA 
Cajamar e APA Cantareira, bem como a APA Várzea Tiete, APA Vargem Grande Paulista, Área de Estudo Serra do Itaqui (Santana Parnaíba), Zonas de Interesse Ambiental Municipal em Franco da Rocha, São Paulo, Caieiras e Barueri.

Entretanto, em meio a todas essas oportunidades representadas pelas áreas de interesse, existem conflitos e barreiras que prejudicam e até mesmo impedem algumas das travessias entre os fragmentos. Em razão da escala e dos recursos empregados para a identificação, foram aqui denominados Conflitos, pois representam as principais descontinuidades no eixo central, como pode ser visualizado no Mapa 24.

\section{PRINCIPAIS CONFLITOS NO EIXO PRINCIPAL}

Os maiores conflitos são decorrentes da travessia das rodovias sobre o eixo principal e de áreas urbanas de pequeno porte. O Rodoanel Sul e Oeste passa distante do eixo; apenas o futuro norte, ainda sem seu traçado totalmente definido, deverá passar bem próximo ou ainda atravessar a Serra da Cantareira, caso seja este o seu traçado.

Como Conflito 1, temos a área urbanizada de Caieiras, que inclui o centro do município, localizada no extremo norte do eixo, contendo áreas de baixo padrão construtivo e muitas habitações precárias, ao longo da rodovia SP 332. A área urbanizada se estende por quase toda a largura do eixo principal e representa uma grande dificuldade para que o Parque Juqueri e todos os demais fragmentos de vegetação do entorno da APA Cantareira e Parque possam ser conectados com o sentido leste do eixo.

Na mesma área, de característica distinta, temos o Conflito 2, referente à rodovia SP 332, que secciona o eixo em destaque, comprometendo e causando interferências aos fluxos de animais. Além disso, traz consigo a capacidade de servir como um vetor de crescimento urbano ao longo de suas margens.

Os Conflitos 3 e 5 dizem respeito, respectivamente, às rodovias Bandeirantes e Anhanguera, que atravessam toda a largura do eixo, significando, portanto, grandes obstáculos e riscos para a travessia de animais que necessitem seguir em direção a APA Cajamar, APA Jundiaí, e APA Cabreúva.

Com as mesmas implicações, temos o Conflito 4, referente à área urbanizada de Cajamar, que inclui seu centro, localizada em uma APA de caráter Estadual e Municipal, de forma que já existem algumas regulamentações de crescimento e desenvolvimento urbano relacionadas com aspectos ambientais. 
O Conflito 6 corresponde à rodovia SP 312, Estrada dos Romeiros. E o Conflito 7, localizado na parte central do eixo, é composto por uma área urbana de Santana de Parnaíba e inclui parte do centro do município.

Um pouco mais a sul, destacamos o Conflito 8, ainda em Santana de Parnaíba, localizando-se no centro do bairro Aldeia da Serra e nos condomínios, alguns dos quais envolvidos por áreas de conservação municipais, Bioma da Mata Atlântica. Bem próximo está o Conflito 9, referente à rodovia Castelo Branco. Mais abaixo, o Conflito 10, em Itapevi, um bairro decorrente de urbanização, com infraestrutura precária, de tamanho extenso e que compromete e ameaça os fluxos ecológicos no eixo principal. Em conjunto, marcamos a Rodovia SP 274 - Rene Benedito da Silva, com o bairro se instalando em suas margens, sendo também uma barreira no eixo.

Já na parte sul do eixo destacamos o Conflito 11, referente a uma pequena parte da área urbanizada de Vargem Grande Paulista. Ainda que a maior parte da área urbanizada se encontre fora do eixo, mais ao lado, gera impactos, conflitos e interferências na dinâmica ecológica.

Mais ao sul, o Conflito 12, que diz respeito à Rodovia Estadual Raposo Tavares; e abaixo, o Conflito 13, relativo a alguns condomínios no município de Cotia - ocupação não muito densa, mas que foi marcada pela proximidade com a Reserva Morro Grande.

Outros conflitos de menor impacto nesta escala de abordagem puderam ser elencados. Em Mairiporã, observamos chácaras e condomínios pulverizados no entorno do parque Estadual da Cantareira e da Zona Proteção Integral Municipal. Há também alguns condomínios do município de Cotia, Santana de Parnaíba, Cajamar, mesmo sendo uma APA.

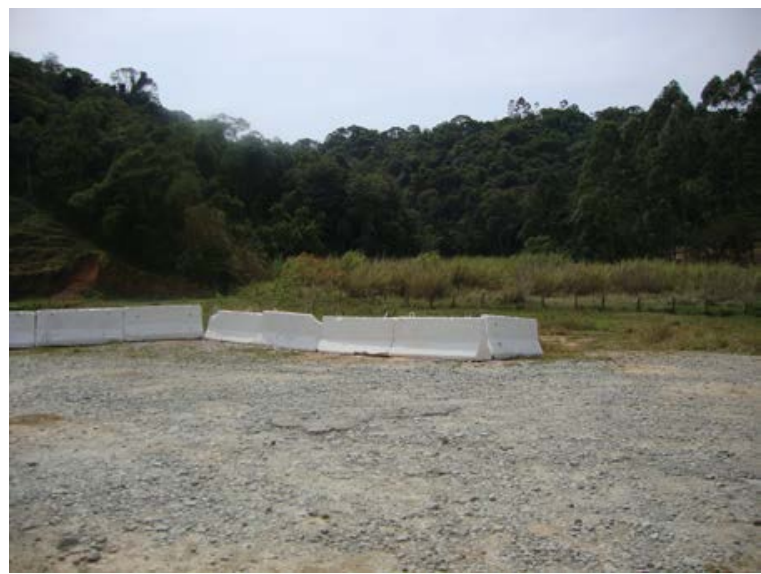

FOTO 15: Fragmento de capoeira localizado no eixo principal proximo à Aldeia da Serra, Barueri. Foto: Julia R. Leite (2011).

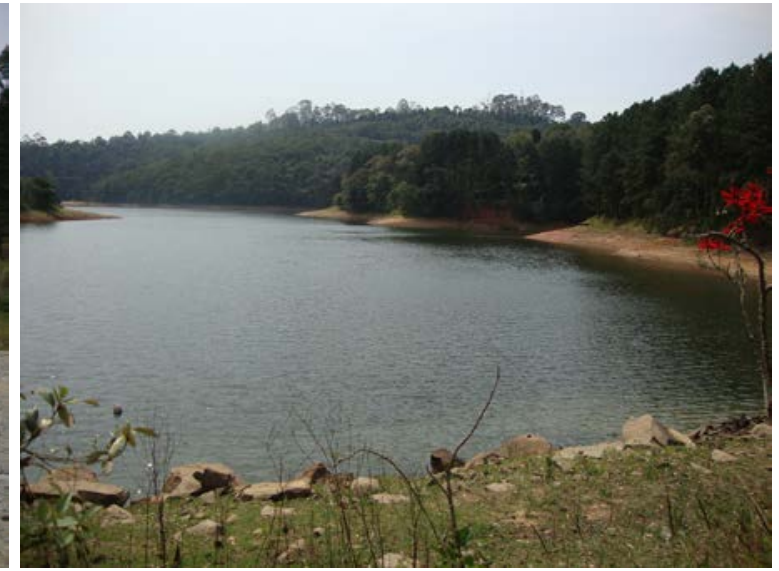

FOTO 16: Lago junto a fragmento de capoeira no condomínio Residencial Aldeia da Serra, localizado no eixo principal, Barueri. Foto: Julia R. Leite (2011).

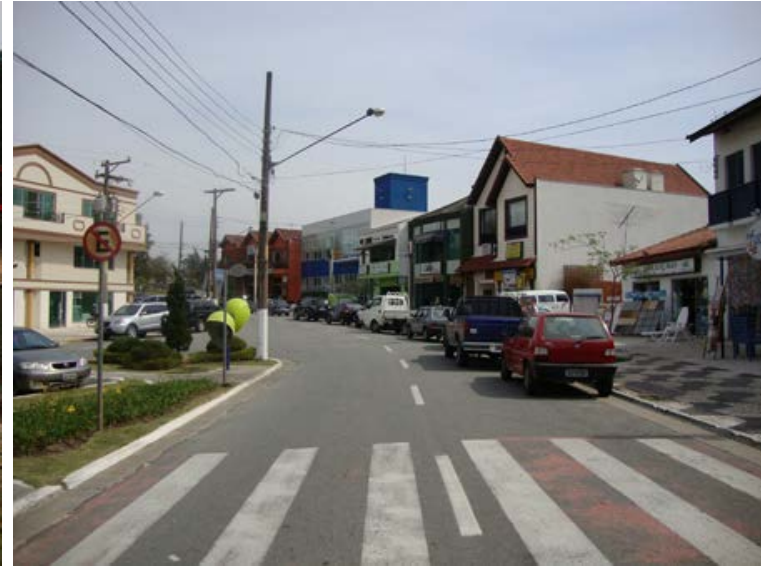

FOTO 17: Centro Comercial de Aldeia da Serra. Barueri-SP. Julia R. Leite (2011). 


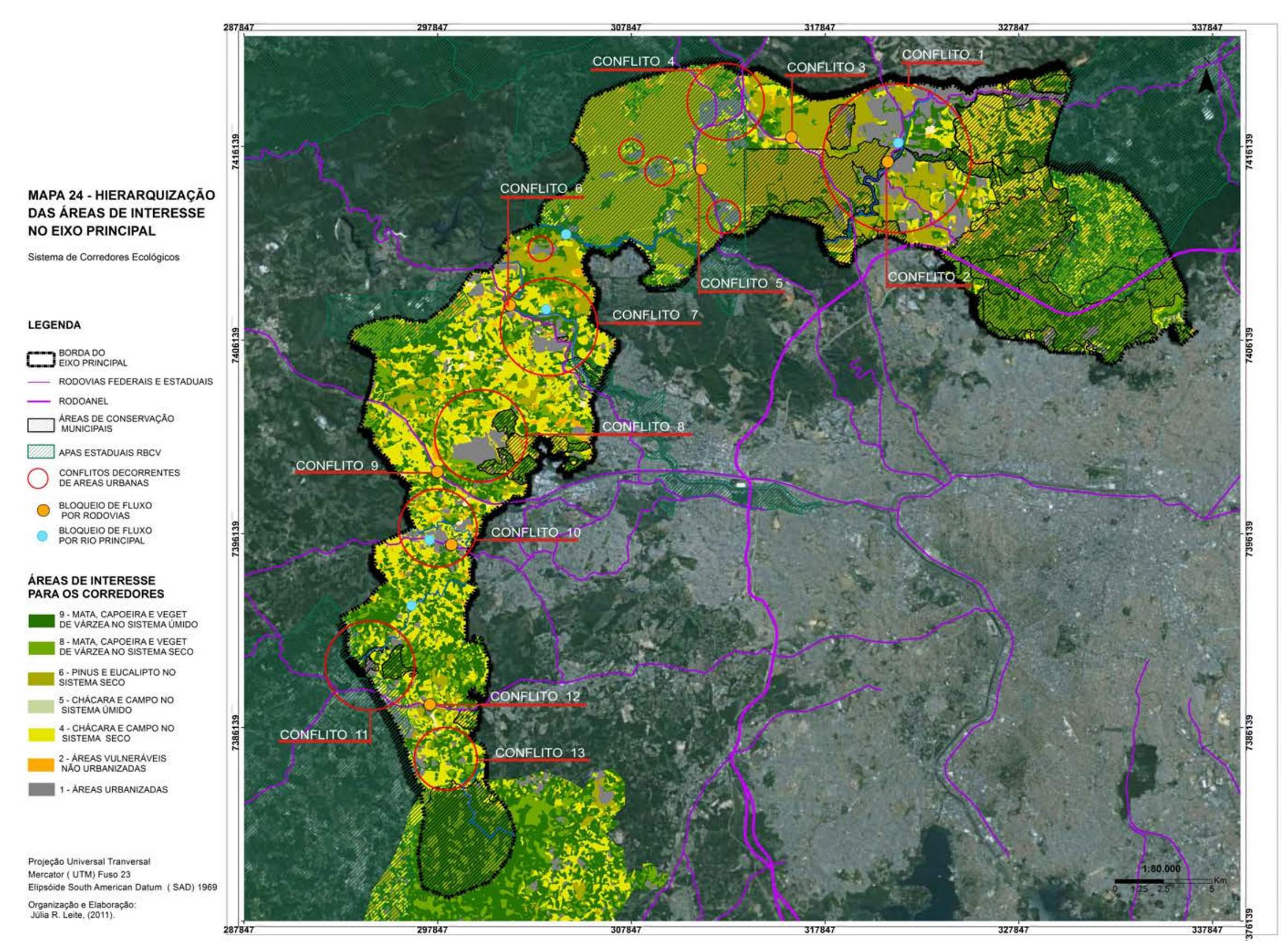




\subsubsection{FAIXA INDICATIVA 1}

A Faixa Indicativa 1, apresentada no Mapa 25 a seguir, possui uma área de $45,14 \mathrm{~km}^{2}$ e contém quatro municípios: Taboão da Serra, São Paulo, Embu e Cotia, sendo que 95\% da área total da faixa estão localizados nos municípios de Embu das Artes (53,66\%) e Cotia $(41,27 \%)$.

A tabela a seguir indica os municípios inseridos na Faixa Indicativa 1:

TABELA 17 - Municípios encontrados na Faixa Indicativa 1 do Sistema de Corredores,

as áreas que ocupam e seus respectivos percentuais(\%).

\begin{tabular}{l|l|l} 
MUNICÍPIOS & ÁREA KM & \multicolumn{1}{c}{$\%$} \\
TABOÃO DA SERRA & 1,30 & $2,85 \%$ \\
\hline SAO PAULO & 0,80 & $1,74 \%$ \\
\hline OSASCO & 0,22 & $0,48 \%$ \\
\hline EMBU & 24,22 & $53,66 \%$ \\
\hline COTIA & 18,63 & $41,27 \%$ \\
\hline ÁREA TOTAL & $\mathbf{4 5 , 1 4}$ & $\mathbf{1 0 0 \%}$
\end{tabular}

A Faixa Indicativa 1 contém muitos fragmentos considerados como a categoria máxima de importância ecológica (9 e 8) ( Mapa 25), distribuídos ao longo de toda a faixa.

Verificamos que a maior parte da faixa está regulamentada por instrumentos de legislação ambiental municipal, como a APA Amigos do Embu, APA EMBU, Parque Municipal Fazenda Tizo (SP), Zonas Homogêneas de Proteção Ambiental (Taboão da Serra) e uma parte da Reserva do Morro Grande (Cotia).

A existência desses instrumentos legais, os quais servem para assegurar a manutenção de funções ecológicas no limite dessas unidades de proteção, infelizmente não garante a integridade dos elementos naturais. Os interesses econômicos e políticos muitas vezes se sobrepõem aos direitos ambientais urbanos; portanto, é preciso que sejam feitos planos e projetos que auxiliem o poder 
público a lidar com as questões e conflitos que existem em áreas como a aqui estudada. Neste caso, a metodologia de planejamento da paisagem desenvolvida possui o papel de auxiliar na concretização de futuros projetos em busca de trazer melhorias ambientais.

Como um conflito de maior magnitude, encontramos o trecho $\mathrm{Su}$ do Rodoanel atravessando sua parte final e, um pouco antes, a Estrada do Embu, segregando o eixo.

A maior parte dos conflitos decorre de núcleos urbanos que estão instalados no município de Embu das Artes e alguns em Cotia.

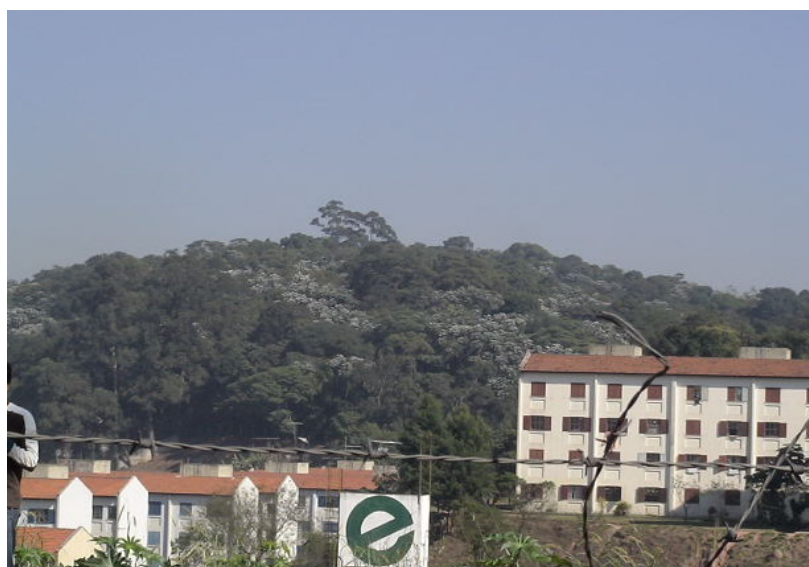

FOTO 19: Fragmento de Mata em Área Homogênea de Proteção Ambiental. Taboão da Serra-SP. Foto: Julia R. Leite (2008).

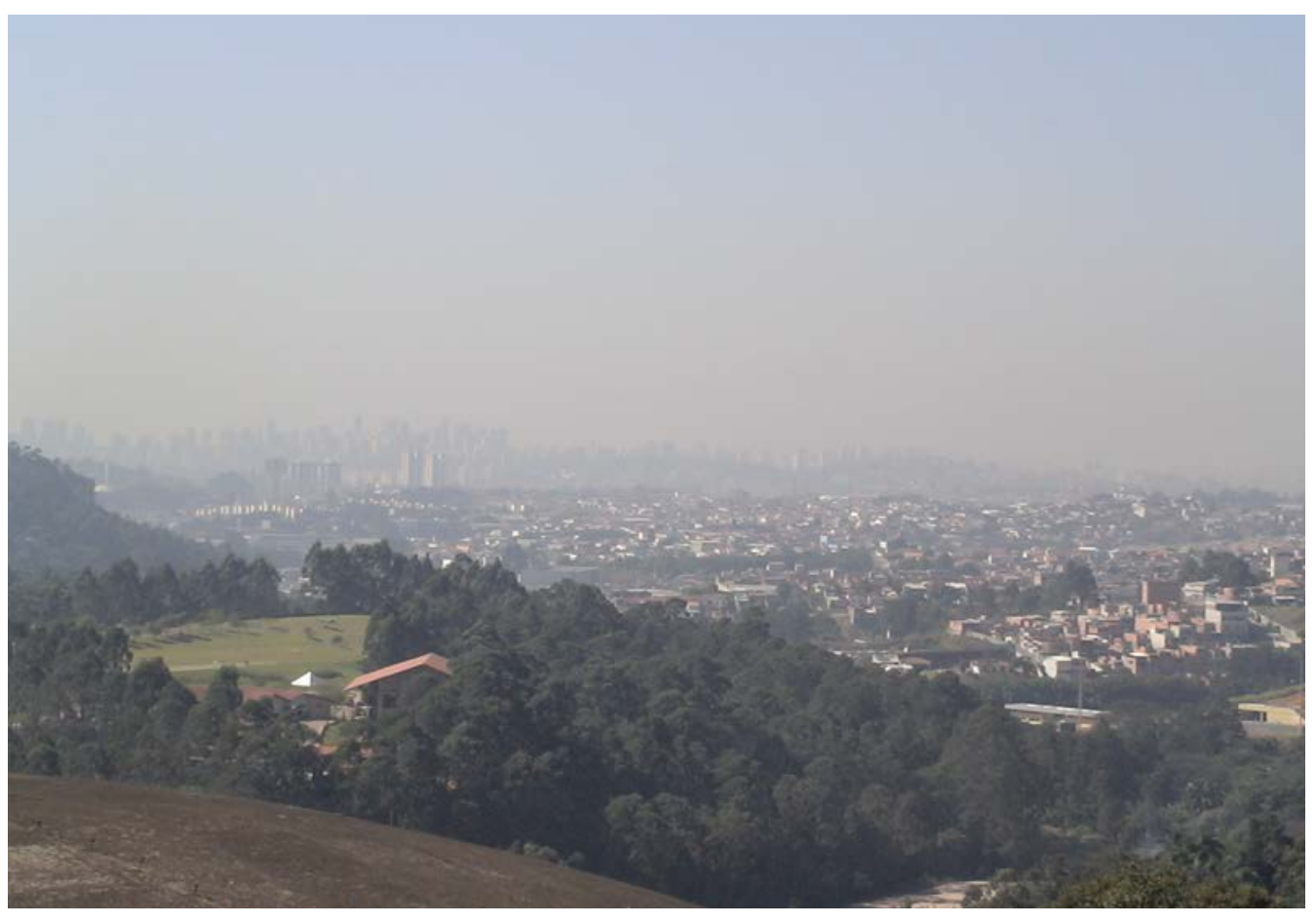

FOTO 20: Fragmento de Mata em Área Homogênea de Proteção Ambiental. Taboão da Serra-SP. Foto: Julia R. Leite (2008). 


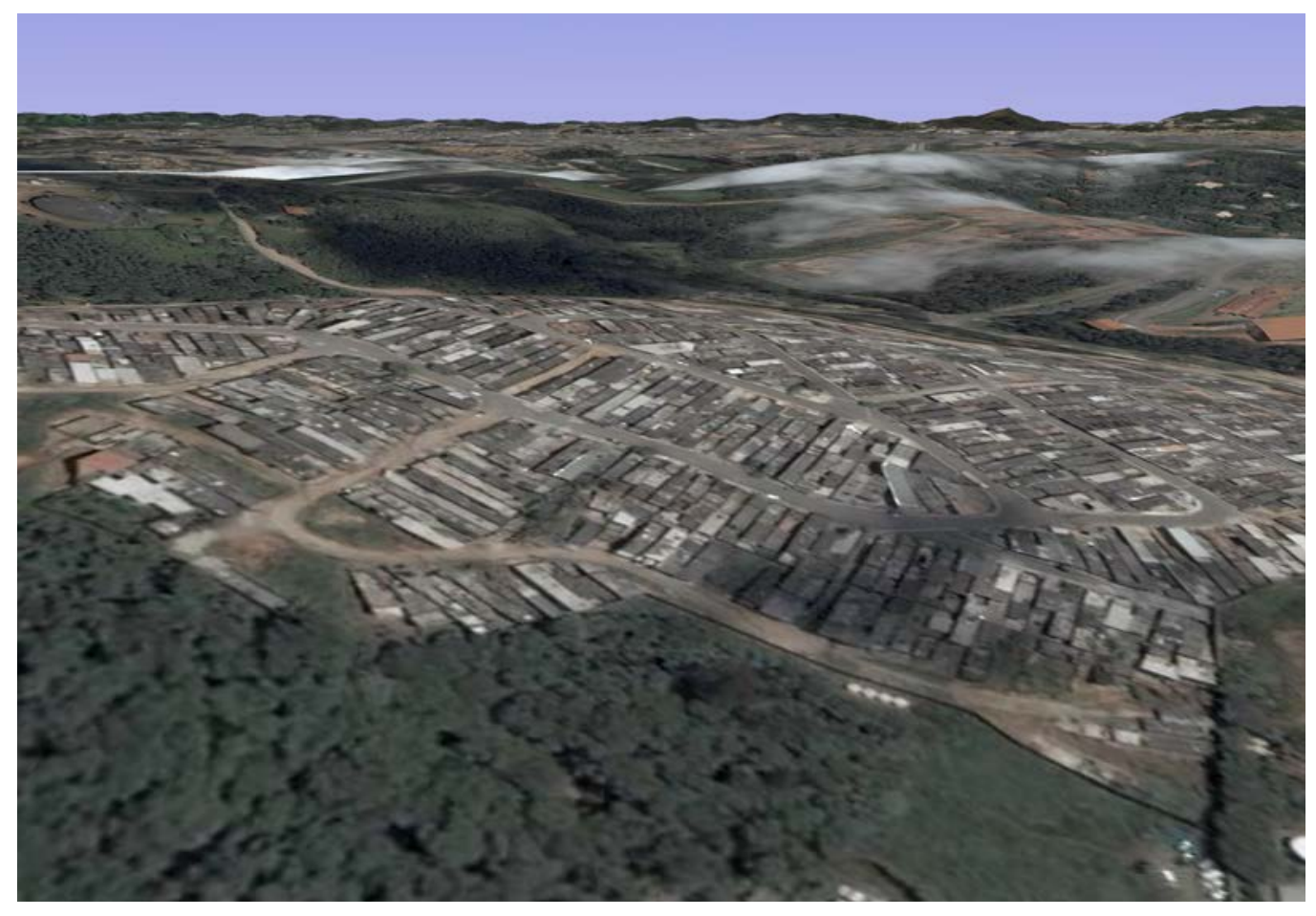

FOTO 20: Fragmento de Mata em Área Homogênea de Proteção Ambiental. Taboão da Serra-SP. Foto: Google Earth (2008).

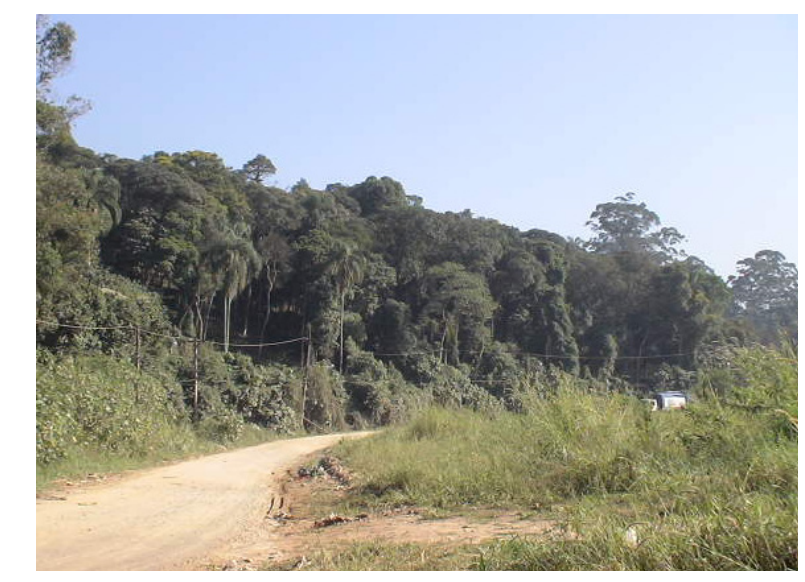

FOTO 21: Fragmento de Mata em Área proposta para ser uma APA Municipal.Taboão da Serra-SP. Foto: Julia R. Leite (2008). 


\subsubsection{FAIXA INDICATIVA 2}

A Faixa Indicativa 2, Mapa 25 a seguir, possui uma área de 19,42 km² e contém quatro municípios: Jandira, Itapevi, Cotia e Carapicuíba, sendo que Cotia representa $56,44 \%$ da área total.

Os fragmentos com graus de importância de maior valor - 9 e 8 - estão concentrados em suas extremidades, próximos ao eixo principal, e alguns no final. A parte central, onde se encontra a maior parte dos condomínios, concentra áreas com graus de importância alta e média (6 e 4). O Rio Cotia atravessa a faixa em destaque, com meandros naturais e vegetação em suas margens, aumentando a importância ecológica da área.

Existe uma rodovia estadual que atravessa a área indo ao encontro da Rodovia Raposo Tavares, e representa uma barreira para a travessia e interação entre os dois lados da faixa. A faixa mantém contato próximo com núcleos urbanos dos municípios de Jandira, Barueri, Itapevi e Carapicuíba, que exercem pressão para o desenvolvimento avançar sobre as áreas com vegetação. $\mathrm{Na}$ faixa em destaque, identificamos o zoneamento do plano diretor municipal de Carapicuíba, que define áreas de proteção e urbanização controladas para tal setor.

TABELA 18 - Municípios encontrados na Faixa Indicativa 2 do Sistema de Corredores, as áreas que ocupam e seus respectivos percentuais(\%).

\begin{tabular}{lll} 
MUNICIPIO & $\mathrm{KM}^{2}$ & $\%$ \\
JANDIRA & 2,67 & $13,76 \%$ \\
\hline ITAPEVI & 2,93 & $15,07 \%$ \\
\hline COTIA & 10,96 & $56,44 \%$ \\
\hline CARAPICUIBA & $2,86 \quad 1$ & $4,73 \%$ \\
ÁREA TOTAL & $19,42 \mathrm{Km}^{2}$ & $100,00 \%$
\end{tabular}


Parte da faixa corresponde aos loteamentos e condomínios da Granja Viana, em Carapicuíba, sendo que alguns deles possuem ainda fragmentos de mata e capoeiras. O principal uso é de condomínios de médio e alto padrão, o que traz conflitos aos fluxos.

No que se refere a rodovias e estradas, verificamos a Estrada de São Fernando, que liga a Rodovia Raposo Tavares a Barueri. Além de barreira, atua como vetor de crescimento urbano, pois muitos condomínios estão sendo construídos na região. Outra estrada que secciona a área é a Estrada de Roselândia, conectada ao centro de Itapevi. Uma grande mancha verde, de matas e capoeiras, está localizada nos limites de Itapevi e Cotia.

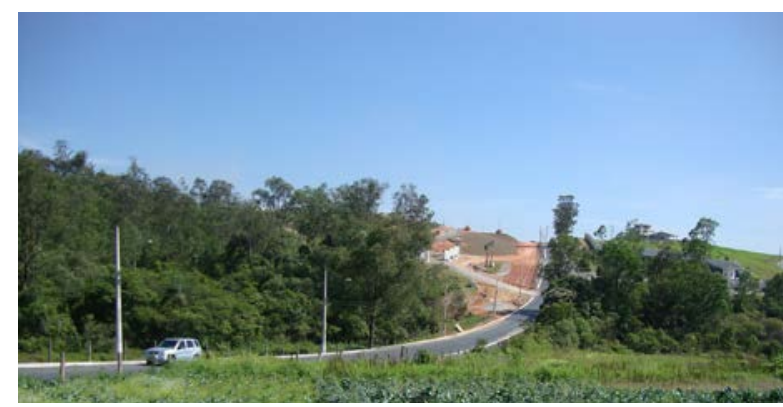

FOTO 22: Estrada de São Fernando seccionando duas manchas de vegetação. Observa-se grande condomínio de alto padrão em construção na área. Carapicuíba -SP. Foto: Julia R. Leite (2011).

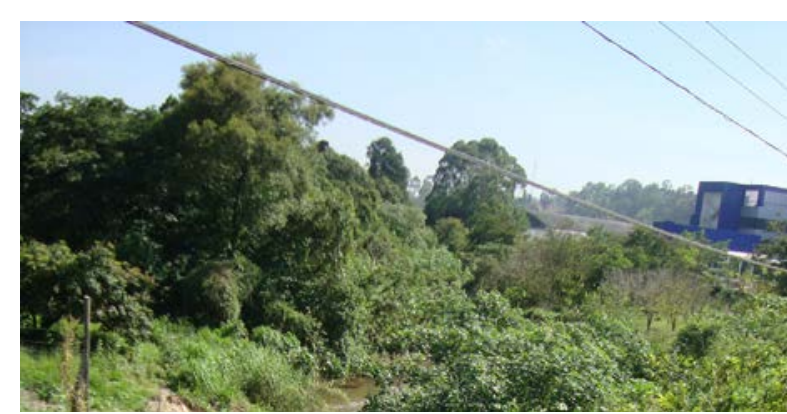

FOTO 24: Rio Cotia com suas margens naturalizadas próximo à área urbana. Barueri -SP. Foto: Julia R. Leite (2011).

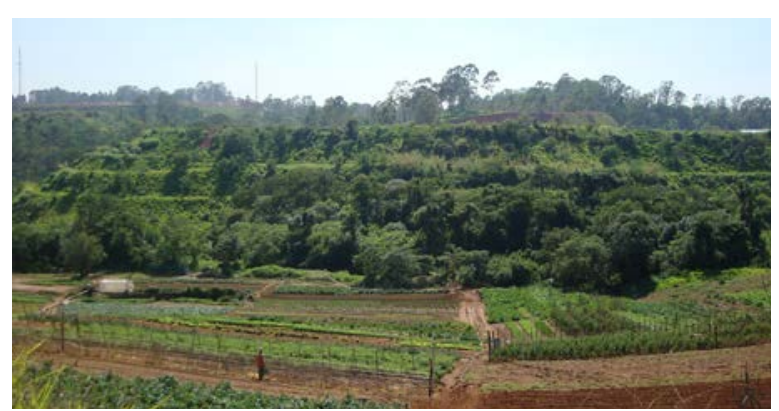

FOTO 23: Vegetação de mata e capoeira na margem do Rio Cotia, na Estrada São Fernando, também utilizada para agricultura familiar. Carapicuíba -SP. Foto: Julia R. Leite (2011).

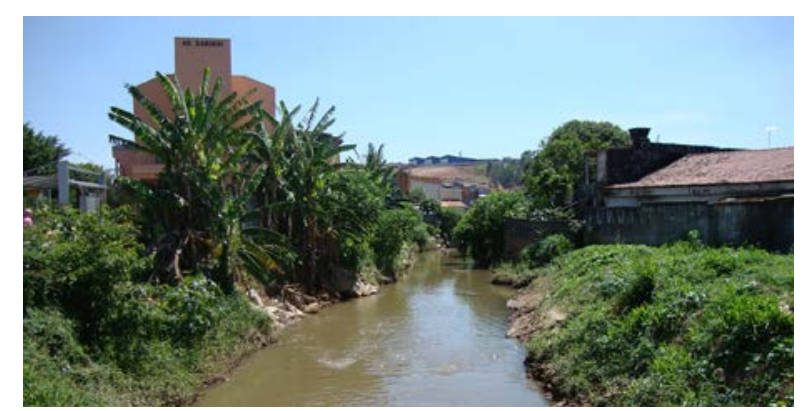

FOTO 25: Rio Cotia com suas margens naturalizadas, já mais deteriorado e poluído, em área urbana, próximo a sua foz. Barueri -SP. Foto: Julia R. Leite (2011) 


\subsubsection{FAIXA INDICATIVA 3}

A Faixa 3, indicada no Mapa 25 a seguir, possui uma área de 15,41 km² e contém três municípios: Jandira, Itapevi e Barueri.

Nesta faixa verificamos escassez de fragmentos com maiores graus de importância. Há um grande fragmento com classe 9 no centro da faixa, que corresponde à Vila Militar (Barueri), e no final do trecho, fragmentos próximos à APA Tietê.

Com relação às áreas protegidas por instrumentos legais, temos, em Jandira, a Zona Especial de Interesse Ambiental - Cidade da Família e a Área de Recuperação Ambiental Antigo Lixão, ambas definidas pelo Plano Diretor Municipal. Em Barueri, existe a Vila Militar, que possui um patrimônio ecológico, com matas e nascentes de propriedade da Polícia Militar. Há também um trecho localizado na APA Tietê.

A Faixa 3 se encontra num local entremeado por centros urbanos adensados dos municípios de Barueri, Itapevi e Santana de Parnaíba. Tal situação lhe confere um aspecto de fragilidade pela pressão de crescimento urbano a que está sujeita. Além disso, possui uso industrial no seu lado oeste.

TABELA 19 - Municípios encontrados na Faixa Indicativa 3 do Sistema de Corredores, as áreas que ocupam e seus respectivos percentuais(\%)

\begin{tabular}{lll} 
MUNICIPIO & $\mathrm{KM}^{2}$ & $\%$ \\
JANDIRA & 1,17 & $7,67 \%$ \\
\hline ITAPEVI & 7,39 & $48,30 \%$ \\
\hline BARUERI & 5,52 & $56,44 \%$ \\
\hline CARAPICUIBA & 2,86 & $42,57 \%$ \\
ÁREA TOTAL & $15,31 \mathrm{Km}^{2}$ & $100,00 \%$
\end{tabular}


A principal rodovia que atravessa a faixa em destaque é a Rodovia Castelo Branco, que passa por uma pequena parte do eixo, e a acompanha, lateralmente, fora do limite, mas por quase toda sua extensão, devendo, portanto, ser evidenciada, bem como as suas implicações para o sistema de corredores. Com suas manchas de vegetação, este eixo funciona como um corredor lateral de amortecimento da margem sul da rodovia. Duas estradas de maior expressão segmentam o trecho, a Estrada dos Romeiros, SP-274, na Vila Militar em Barueri, e a Estrada de Jandira, no município homônimo. Existe uma série de ruas urbanas que cruzam o eixo, causando conflitos com o corredor.

A foz do Rio Cotia e a do Rio Barueri-Mirim no rio Tietê se encontram nesta faixa. Estão localizadas no centro comercial de Barueri, sendo ambas canalizadas. O Rio Barueri-Mirim está tamponado, não só na sua foz, mas em praticamente toda sua extensão.

Em Jandira, observamos o uso residencial com condomínios e bairros; em Itapevi, a presença de indústrias e condomínios que interferem na dinâmica do corredor.

Alguns registros fotográficos são apresentados a seguir:

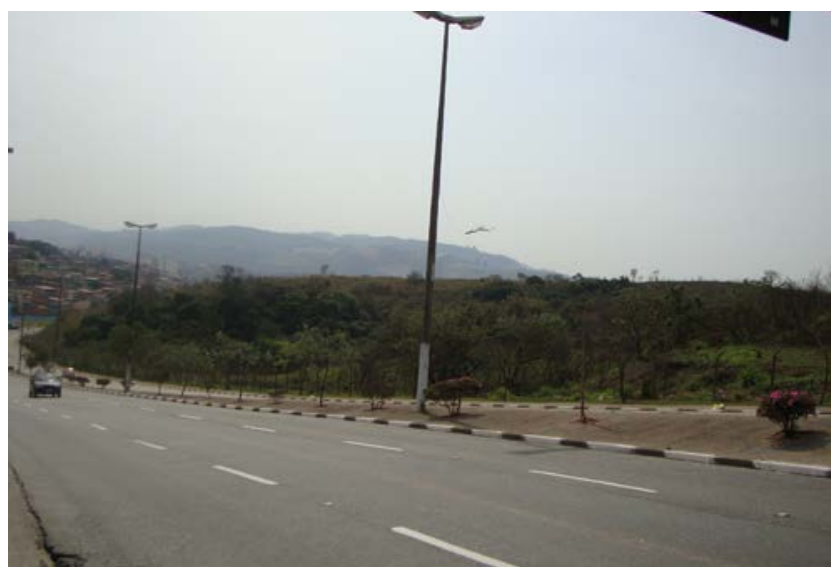

FOTO 26: Fazenda Militar - Área verde extensa em Barueri. Foto: Julia R. Leite (2011).

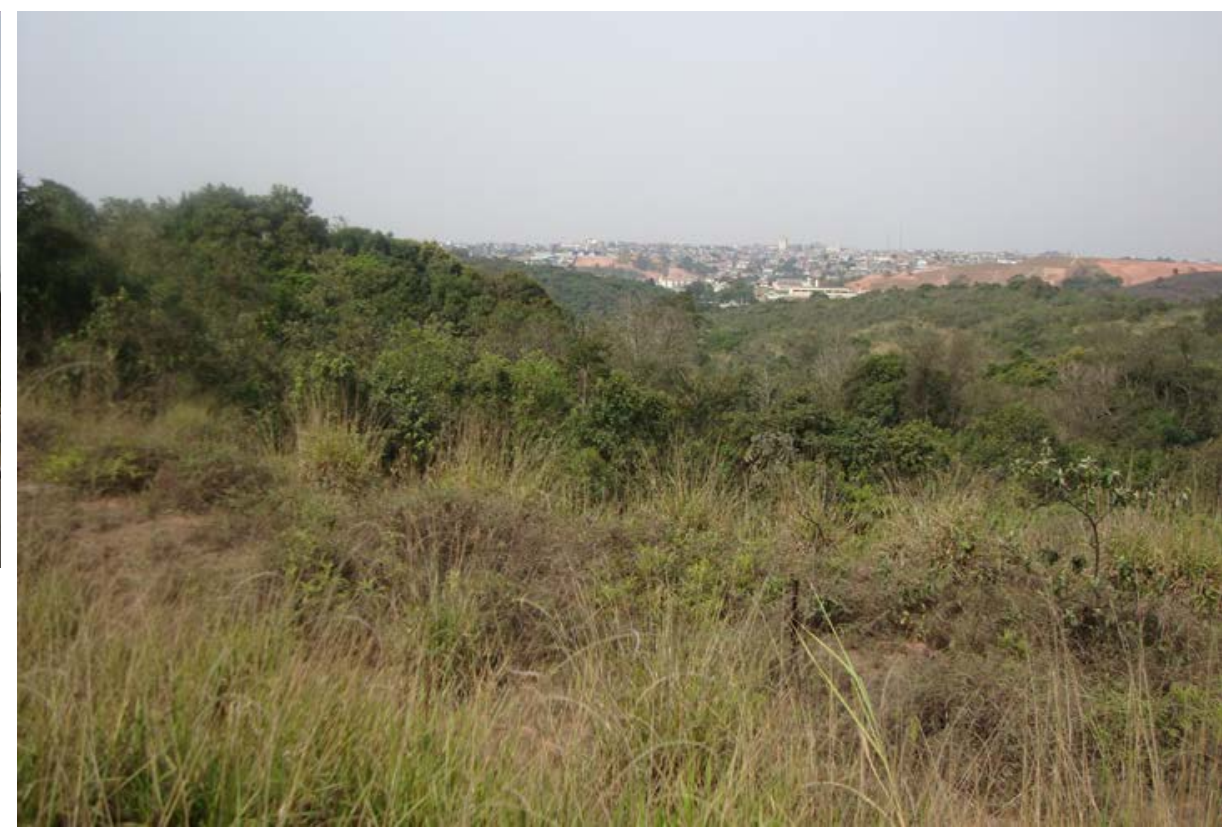

Foto 27: Fazenda Militar - Área verde extensa em

Barueri. Foto: Julia R. Leite (2011). 


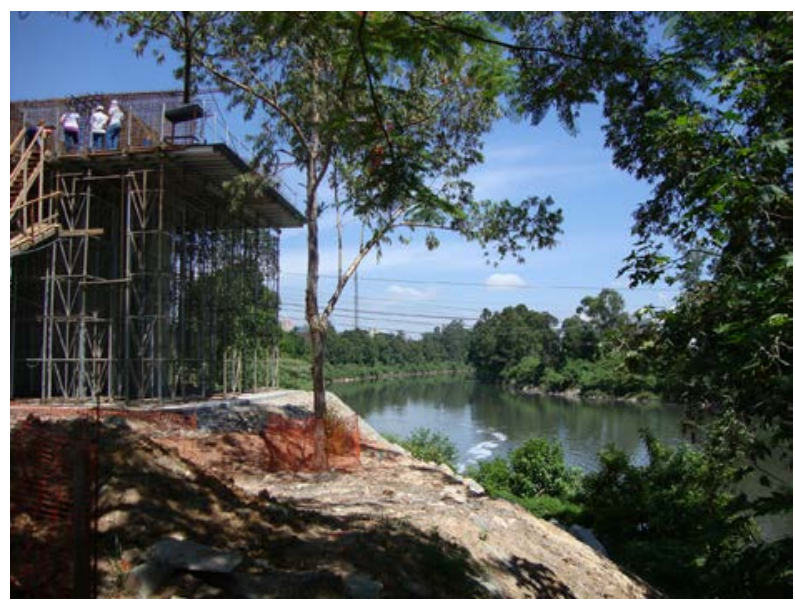

FOTO 28: Rio Tietê e a Foz do Rio Cotia.

Construção de ponte até os condomínios Alphaville.

Barueri-SP. Foto: Julia R. Leite (2011).

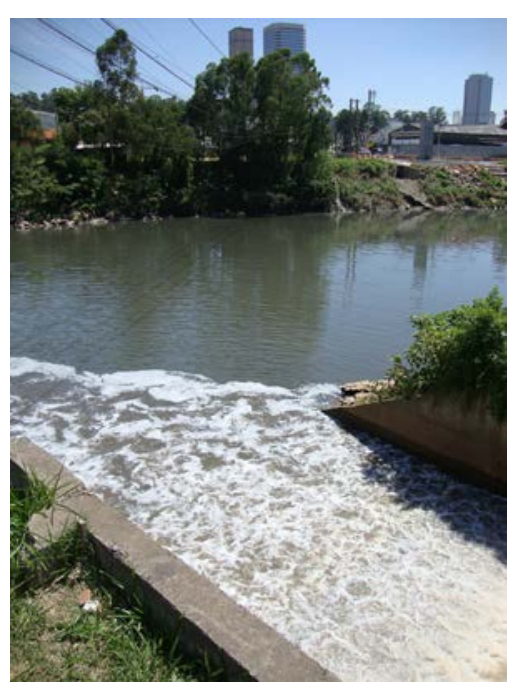

FOTO 30: Foz do Rio Cotia no

Rio Tietê. Barueri-SP.

Foto: Julia R. Leite (2011).

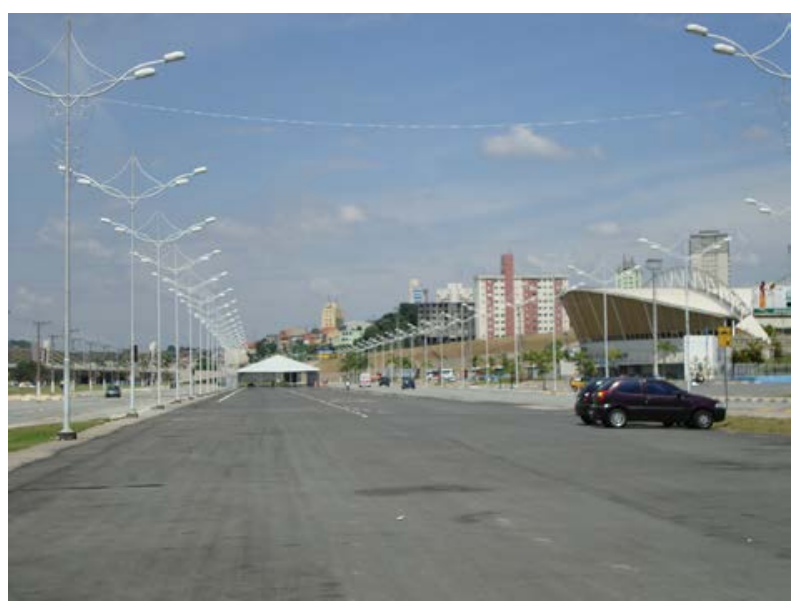

FOTO 29: Rio Barueri Mirim tamponado, próximo a sua foz, no Rio Tietê. A área do antigo rio foi transformada em um grande estacionamento. Barueri-SP. Foto: Julia R. Leite (2011).

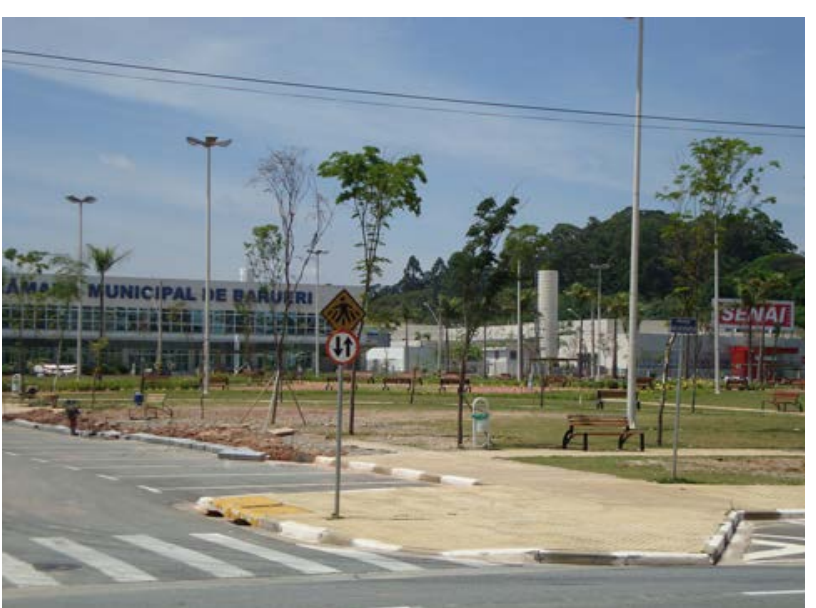

FOTO 31: Área tamponada do rio Barueri Mirim sobre a qual foram criados jardins públicos ornamentais de escasso valor ecológico e de uso obsoleto por parte

da população. Barueri-SP. Foto: Julia R. Leite (2011). 


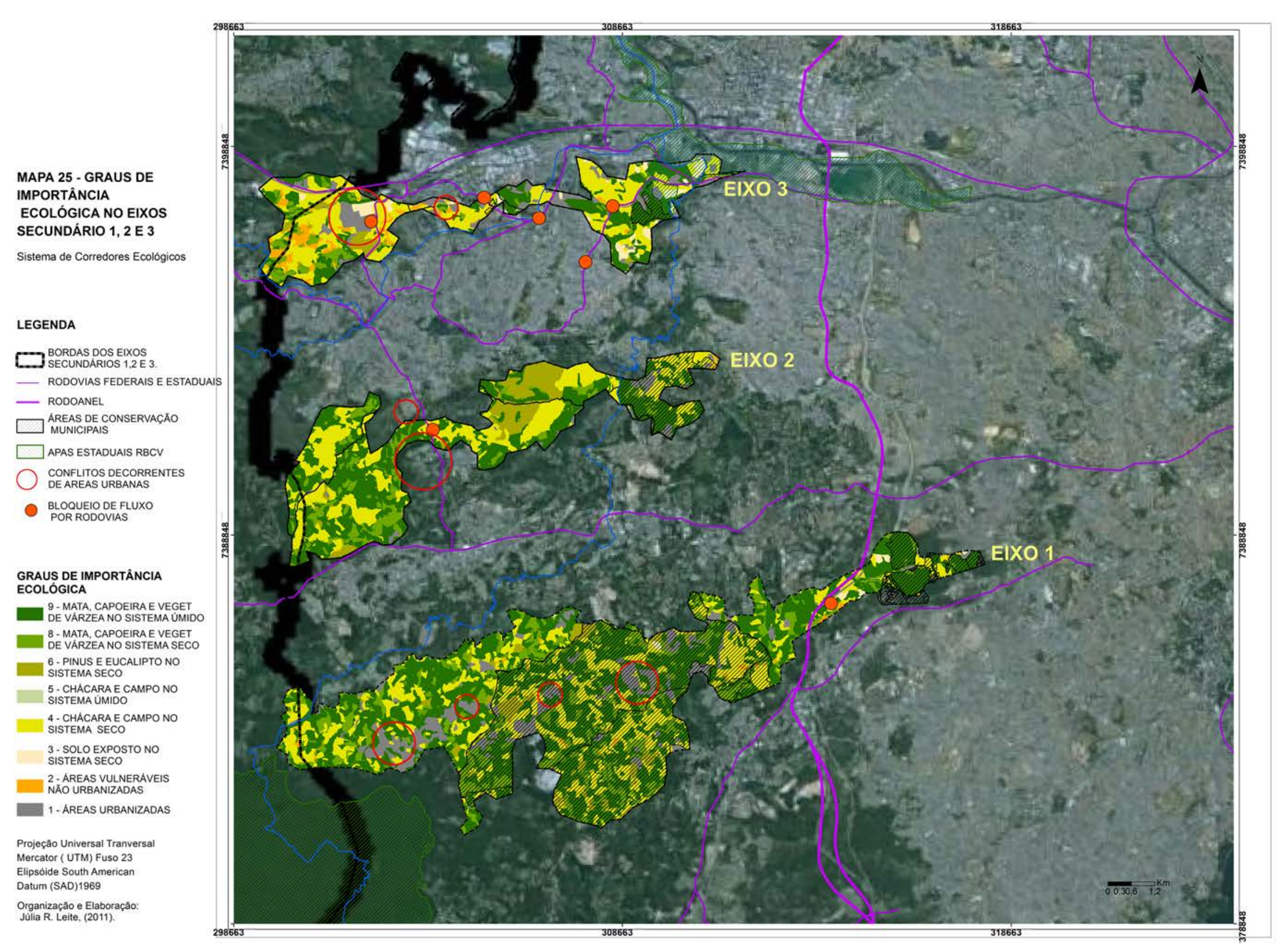




\subsubsection{FAIXA INDICATIVA 4}

A Faixa Indicativa 4 indicativa (Mapa 24 a seguir) possui uma área pequena de $7,17 \mathrm{~km}^{2} \mathrm{e}$ contém dois municípios: Santana de Parnaíba e Barueri.

TABELA 20: Municípios encontrados na Faixa Indicativa 4 do Sistema de Corredores, as áreas que ocupam e seus respectivos percentuais(\%).

\begin{tabular}{lll} 
MUNICIPIO & $\mathrm{KM}^{2}$ & $\%$ \\
SANTANA DE PARNAÍBA & 5,31 & $74,12 \%$ \\
\hline BARUERI & 1,85 & $25,88 \%$ \\
\hline \multirow{2}{*}{ ÁREA TOTAL } & & \\
& 7,17 & $100,00 \%$
\end{tabular}

Esta área possui poucos fragmentos localizados na junção da Faixa Indicativa 4 com o Eixo Principal adjacente. É circundada por centros urbanos dos municípios de Barueri e Santana de Parnaíba. A Rodovia SP 312 - Estrada dos Romeiros segue paralela à faixa. Não observamos barreiras de rios e rodovias.

A grande mancha de vegetação com alta importância para os fluxos ecológicos, em visualização de imagem recente disponibilizada pelo aplicativo Google Earth, foi sobreposta por um condomínio ainda em lotes, mesmo em uma área do Parque Ecológico Tietê. Tal condomínio pode se conformar como um elemento de barreira aos fluxos ecológicos. A área de proteção presente na faixa é o setor oeste da APA Várzea do Rio Tietê, que se estende de Barueri até Santana de Parnaíba, com seu núcleo Tamboré, onde o parque ecológico está localizado. O parque conta com a margem do Rio Tietê, e muitas árvores, mas não se configura como uma área de matas abundantes, e sim com um pouco de capoeira esparsa (IF, 2010) e árvores ornamentais, configurando uma grande área verde. Durante a semana, o parque tem acesso restrito, e aos finais de semana, é aberto à população para lazer. 


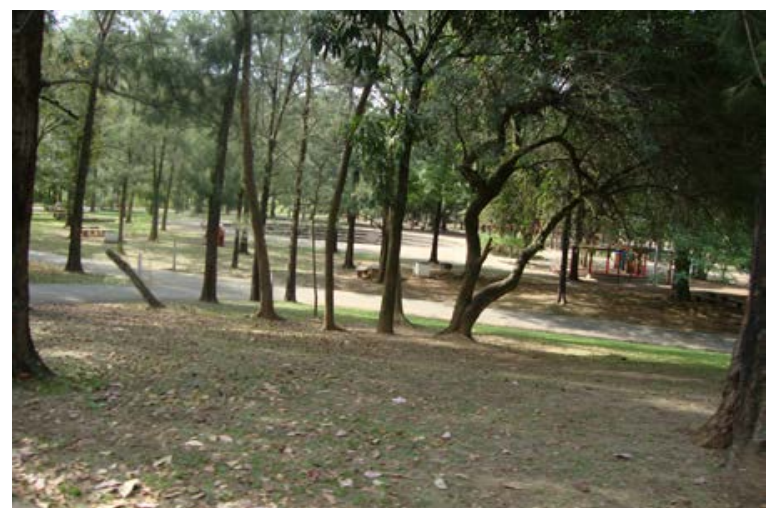

FOTO 32: Parque Ecológico Tietê-Núcleo Tamboré. Barueri-SP. Foto: Julia R. Leite (2011).

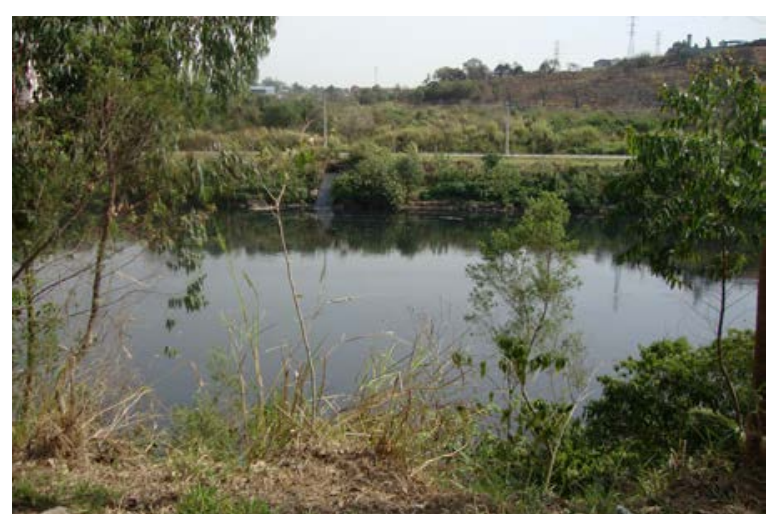

FOTO 34: Parque Ecológico Tietê-Núcleo Tamboré. Detalhe da margem do Rio - Barueri-SP. Foto: Julia R. Leite (2011).

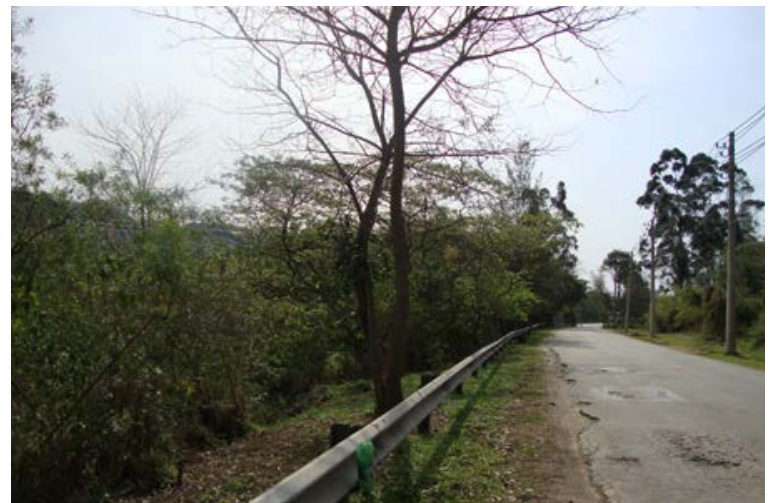

FOTO 33: Estrada de acesso ao Parque Ecológico Tietê-Núcleo Tamboré. Barueri-SP. Foto: Julia R. Leite (2011).

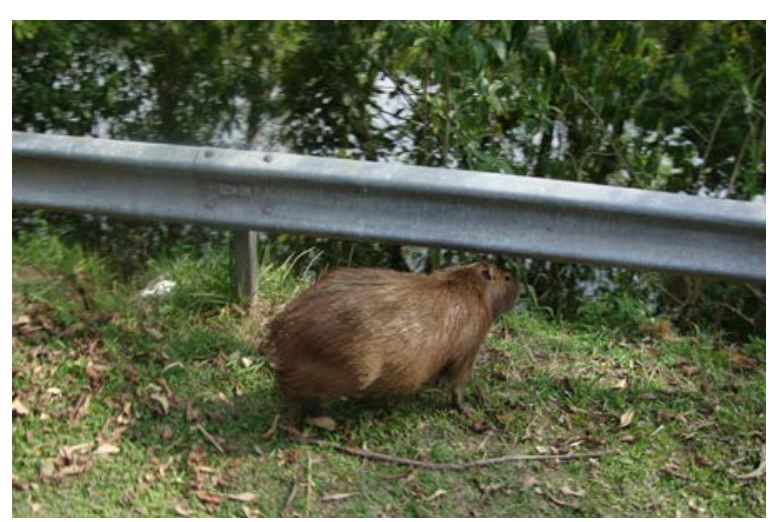

FOTO 35: Capivara junto à margem do Rio Barueri. Foto: Julia R. Leite (2011). 


\subsubsection{FAIXA INDICATIVA 5}

A Faixa 5 tem formato de semicírculo, o que a distingue das demais. Sua área total também é a maior, com $76,13 \mathrm{Km}^{2}$, sendo nela inseridos cinco municípios: São Paulo, Santana de Parnaíba, ambos com maior porcentual da área total $(47,14 \%$ e 35,59\%), Osasco, Cajamar e Caieiras.

Trata-se da faixa indicativa que mais contém áreas com importância para os fluxos ecológicos. Com relação às áreas de conservação, temos, em Santana de Parnaíba, a Reserva Biológica Tamboré, que é municipal. Em São Paulo, encontramos zonas de interesse ambiental definidas pelo Plano Diretor Municipal, e o Parque Anhanguera, também municipal. Em Caieiras, temos uma pequena parte de zona de interesse ambiental definida pelo plano diretor, e em Cajamar, uma pequena parte também da APA Estadual de Cajamar.

Com relação a Osasco, não obtivemos informações relacionadas às áreas de proteção municipais.

$\mathrm{O}$ sistema viário representa um grande conflito aos fluxos ecológicos dentro da faixa. O primeiro deles se refere à Rodovia Anhanguera, na altura da divisa dos municípios de São Paulo e Osasco, e o segundo, à Rodovia dos Bandeirantes, em São Paulo, no final da faixa. O trecho Norte do Rodoanel, ainda não construído, deverá seccionar a Faixa 5 em dois locais, representando a maior barreira aos fluxos ecológicos, passando por Santana de Parnaíba, em áreas com valores ecológicos, e pelo Parque Municipal Anhanguera.

Núcleos urbanos de Santana de Parnaíba, São Paulo (bairros Perus, Anhanguera e Morro Doce) e Cajamar foram destacados pela sua proximidade com a Faixa 5. No meio do semicírculo, observamos bairros populares adensados com habitações precárias. Ao sul da faixa, no município de Santana de Parnaíba, há condomínios de alto padrão; em Osasco, são visualizados bairros populares.

TABELA 21 : Municípios encontrados na Faixa Indicativa 5 do Sistema de Corredores, as áreas que ocupam e seus respectivos percentuais(\%).

\begin{tabular}{lll} 
MUNICIPIO & $\mathrm{KM}^{2}$ & $\%$ \\
SÃO PAULO & 27,09 & $35,59 \%$ \\
\hline SANTANA DE PARNAÍBA & 35,89 & $47,14 \%$ \\
\hline OSASCO & 3,10 & $4,07 \%$ \\
\hline CAJAMAR & 1,68 & $2,21 \%$ \\
\hline CAIEIRAS & 8,37 & $10,99 \%$ \\
\hline TOTAL & 76,13 & $100,00 \%$
\end{tabular}


MAPA 26 - GRAUS DE

ECOLÓGICA NO EIXOS

SECUNDÁRIOS $4 \mathrm{E}$

Sistema de Corredores Ecológicos

LEGENDA

SORDAS DOS EIXOS

- RoDovias FEDERAIS EESTADUAIS

- RODOANEL

$\square$ MUNICIPAIS

apas estaduals RBCV

CONFLITOS DECORRENTES
DE AREAS URBANAS

BLOQUEIO DE FLUXO
POR RODOVIAS

GRAUS DE IMPORTÂNCIA
ECOLÓGICA

9- MATA, CAPOEIRA E VEGET

8. MATA, CAPOEIRAE VEGET

6. PINUS E EUCALIPTO NO

5. CHACARA E CAMPO NO

SISTEMAUMIDO

4. CHACARA E CAMPO NO

3- SOLO EXPOSTO

2. AREAS VULNERAVEIS

1. AREAS URBANIZADAS

Projeçăo Universal Tranversal

Mercator ( UTM) Fuso 23

Elipsoide South Americ

Organizaçăo e Elaboração:
Jülia R. Leite, (2011).

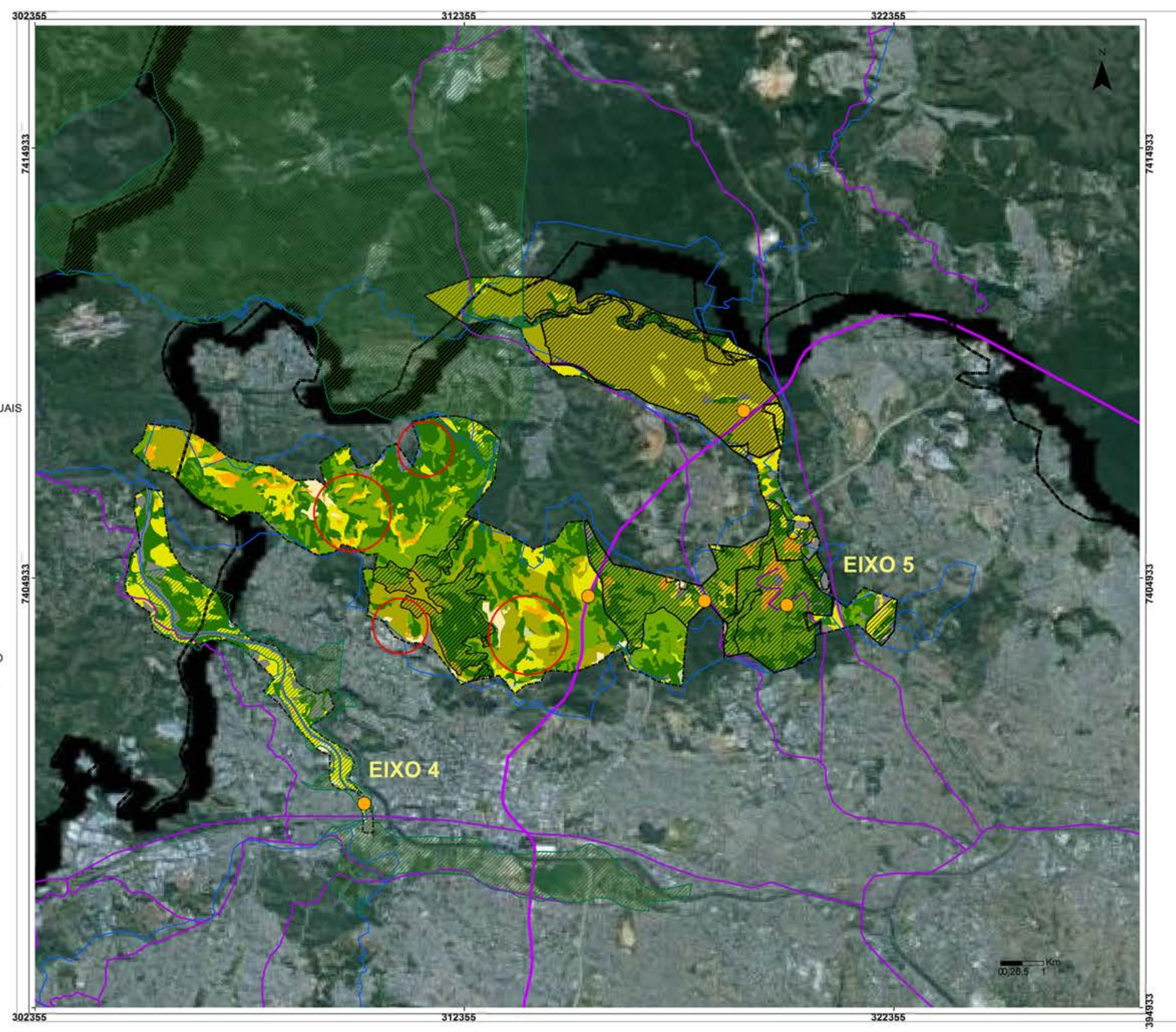




\subsection{RESOLUÇÃO DE CONFLITOS}

Mesmo com as possibilidades aqui apresentadas e exemplificadas, para que o Sistema de Corredores Ecológicos possa ser implementado, é preciso considerar alguns conflitos e barreiras encontrados que dificultam e até mesmo impedem conexões.

Compreendemos que as áreas ligadas por matas e capoeiras ou por campos naturalizados atenderiam mais adequadamente aos fluxos ecológicos dos corredores, configurando-se como a condição ideal para um contínuo ecológico. Entretanto, a paisagem estudada corresponde a um mosaico de usos, e precisamos incluir as outras conexões nela existentes, valorizando também as intermediárias aos fluxos, ou seja, aquelas que não são totalmente impeditivas nem totalmente favorecedoras. Como exemplo dessas conexões intermediárias, podemos citar loteamentos residenciais de baixa densidade de ocupação e alto índice de áreas abertas; loteamentos de chácaras com lagos, riachos, pomares, vegetação de porte arbóreo, bosques de eucaliptos e pinus. Entendemos que os bosques de Eucaliptos sp. são ainda mais favorecedores do que os segundos, já que permitem o surgimento de sub-bosques e a regeneração espontânea de espécies vegetais nativas. São, portanto, situações ainda bastante positivas a fluxos ecológicos.

Há ainda as conexões interrompidas, que são as situações de conflitos e barreiras. Quando não puderem ser contornadas, como no caso das rodovias ou núcleos urbanos adensados, devem ser solucionadas por projetos específicos.

Para o estabelecimento dos corredores, o ideal é manter e conectar áreas com vegetação para o uso como habitat e deslocamento de animais (HILTY et al., 2006). Assim, no presente estudo, procuramos priorizar contornar os grandes e médios núcleos urbanos, de maneira a destinar áreas adjacentes às urbanas como favoráveis aos fluxos ecológicos. Ainda assim, devemos incluir todos os gradientes de ocupação, tanto rurais como urbanos, como sendo potenciais para a condução de fluxos ecológicos diferenciados, ou seja, de espécies vegetais e de fauna mais generalistas, que deverão se beneficiar, por meio de elementos naturais em áreas não completamente hostis. 


\subsubsection{CONFLITOS CAUSADOS POR NÚCLEOS URBANOS}

No sistema delineado, no eixo principal, com relação à estrutura ecológica da paisagem, não encontramos nenhum bloqueio estrutural decorrente de núcleos urbanos completamente impeditivo à implementação do sistema. Mas, ainda assim, esses bloqueios causam interferências e conflitos ao contínuo de corredores.

Por esse motivo, o traçado dos corredores aqui proposto foi desviado desses núcleos, de maneira a verificarmos sua maior eficiência.

No estudo realizado, podemos citar os conflitos gerados por áreas urbanas compostas por loteamentos de uso restrito. No caso ilustrado (Foto 36) em Barueri, há grande impermeabilização do solo, lotes médios com baixo índice de áreas verdes, em especial no interior dos loteamentos (Conflito 8). A configuração existente, de um anel verde que circunda o bairro, permite inferir que há, atualmente, um fluxo de fauna e hídrico no perímetro da área, ou seja, um deslocamento de animais no entorno do bairro. Nessa situação, algumas espécies de aves podem utilizar a área residencial como passagem e abrigo temporário, devido ao entorno vegetado.

Assim, o aumento do índice de áreas abertas vegetadas no loteamento, como arborização viária e permeabilidade do solo, traria beneficios para fluxos hídricos e para a avifauna, bem como melhorias ambientais, como conforto térmico, lumnico e filtragem de partículas do ar. 


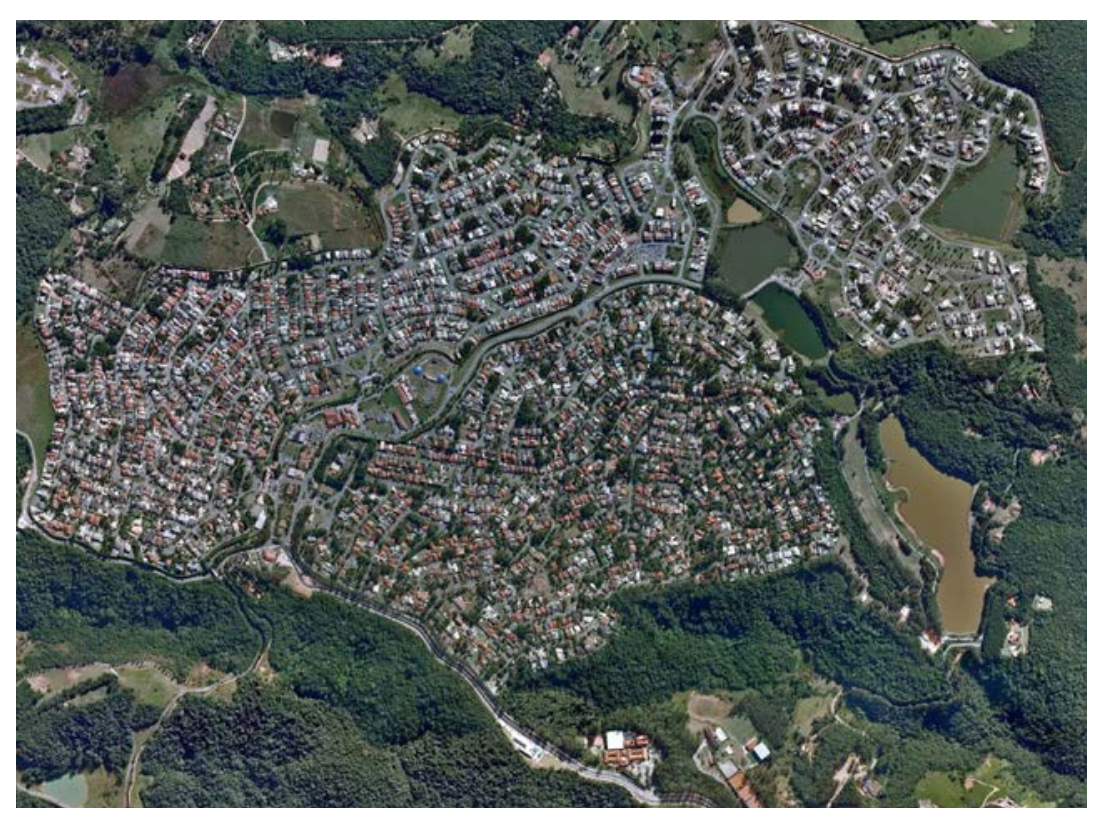

FOTO 36: Conflito 8 - Condomínio em Aldeia da Serra, exemplo de um centro urbano de baixa densidade, com lotes de tamanho médio. Pela grande quantidade de condomínios da região, há descontinuidade no sistema dos corredores.

Em áreas com conflitos causados por loteamentos de baixo padrão (Conflito 10 - Foto 37), algumas vezes irregulares, com habitações e infraestrutura precárias, verificamos, pela observação da imagem de satélite, um menor índice de impermeabilização, mesmo sabendo que, pela ausência de infraestrutura, trata-se de uma situação provisória de ocupação urbana. Nos pequenos lotes, observamos a ausência de áreas verdes, e também, nessa transitoriedade do processo de ocupação ainda em curso, pela imagem observamos a presença de terrenos ainda não construídos.

Tais áreas de conflitos, localizadas no sistema de corredores, devem ser encaradas como oportunidades para se promover um núcleo urbano com os recursos necessários à população. Mas também é fundamental considerar, junto a todos os projetos, as necessidades ecológicas, tanto no que se refere à infraestrutura das vias de passeio e de veículos, como nos edificios residenciais, comerciais e de equipamentos públicos, e ainda para áreas de recreação e lazer, praças e parques. Além disso, é necessário estudar realocações dentro das áreas vulneráveis e das que são impeditivas para continuidades de corredores ecológicos, salvaguardando-as como áreas de riscos e parques. O entorno do bairro possui alguns fragmentos de vegetação e terrenos vagos que remetem a uma ocupação prestes a chegar. 


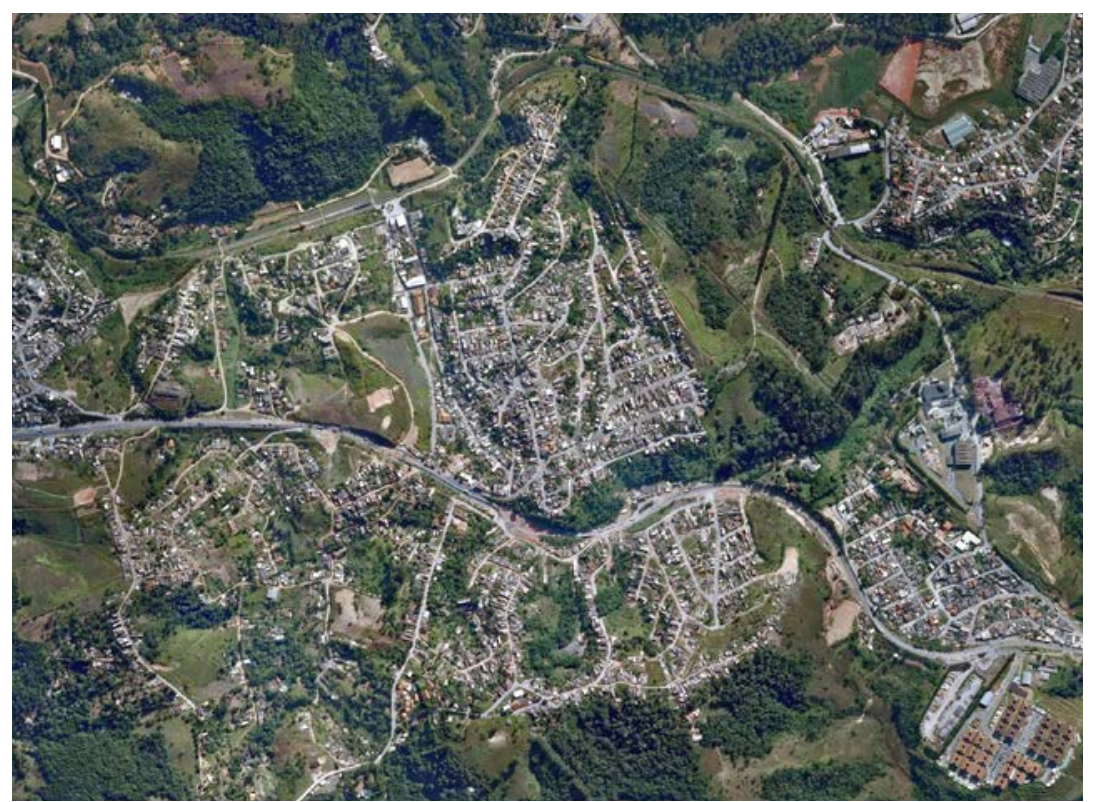

Foto 37: Conflito 10: Bairro popular de Itapevi, com baixa densidade de ocupação, não planejada e deficiente de infraestrutura urbana. Nota-se a presença de terrenos vazios que ainda tornam o bairro mais permeável e com vegetação capaz de abrigar e conduzir deslocamentos, especialmente da avifauna.

Já nas faixas indicativas secundárias, em algumas situações, verificamos conflitos decorrentes de núcleos urbanos adensados que conformaram descontinuidades, ou seja, interromperam a continuidade estrutural do sistema de corredores. Assim, são faixas que têm seus fragmentos de vegetação de mais qualidade ecológica com tamanhos menores e estão mais próximas à matriz urbana metropolitana e suas interferências; consequentemente, possuem menor importância ecológica dentro do sistema de corredores. 


\subsubsection{CONFLITOS CAUSADOS POR RODOVIAS E ESTRADAS}

As principais rodovias marcadas nos mapas apresentados (como no Conflito 13) representam os maiores conflitos relacionados aos deslocamentos de animais, já que são impeditivas para algumas espécies de mamíferos de menor capacidade de deslocamento e um grande risco para aquelas que conseguem atravessar as faixas das rodovias e são facilmente vítimas de atropelamentos. Para as aves em geral, não representam conflitos impeditivos, apenas para aquelas mais especialistas, que são afugentadas pelos automóveis.

Para a discussão dos conflitos e barreiras causados pela presença de rodovias e inúmeras estradas no Sistema de Corredores Ecológicos delineado, buscamos medidas mitigadoras, como as propostas por Bager (2011).

Segundo o autor, as técnicas de mitigação devem ser buscadas em países cujas experiências de sucesso já se desenvolvem há algumas décadas, mas de modo a fazer adaptações às situações brasileiras.

Em um estudo de ecologia de estradas em Portugal, realizado durante sete anos (2002 a 2009), Grilo (2011) teve como objetivo verificar o efeito delas sobre a fauna regional. $\mathrm{O}$ autor constatou que a taxa de mortalidade foi de 1,18 indivíduos $/ \mathrm{km} / \mathrm{ano}$, sendo que as espécies mais afetadas foram aquelas com distribuição mais generalizada e mais abundante, especialmente do grupo de carnívoros e corujas Com relação aos micro-mamíferos, foi constatado que o efeito barreira das estradas funciona como um misto de repulsa e atração pelas faixas de domínios, o que acaba por gerar um efeito negativo para seus predadores. Assim, a probabilidade de morte de suas presas aumenta, além de não serem intimidados pelas rodovias. Também foi possível

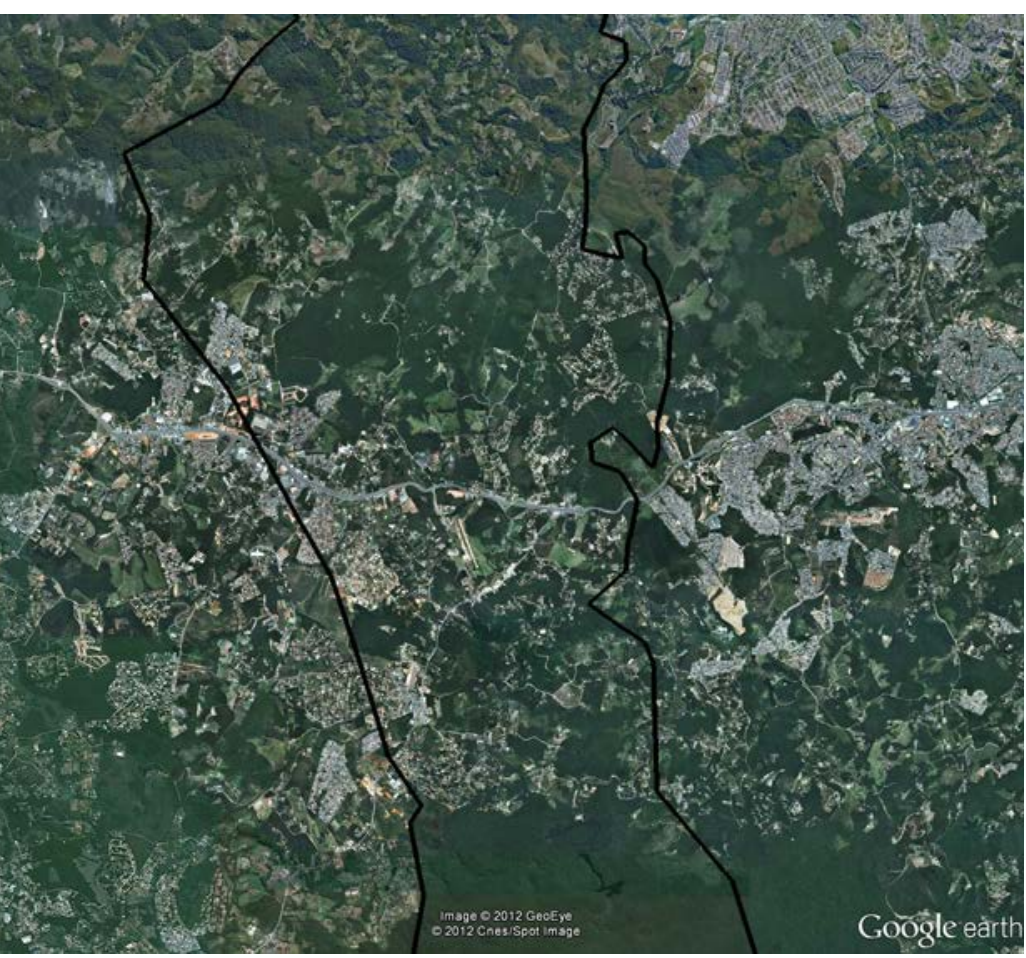

FOTO 38: Detalhe dos Conflito 11 e 13 . O centro de Vargem Grande Paulista avança no sentido da borda do eixo principal e a Rodovia Raposo Tavares que secciona a área. espécie de fuinha (Martes foina), que é aparentemente indiferente às rodovias.

O estudo traz, portanto, exemplos de indivíduos da fauna que apresentam um comportamento indiferente às estradas, tornando-se susceptíveis a atropelamentos. 


\subsection{SETORES SELECIONADOS}

Dando prosseguimento às análises, selecionamos três setores do Eixo Principal (Setor 1, 2 e 3) e as Faixas Secundárias 1 e 3 para discutir com mais detalhes a presença de conflitos e barreiras e as implicações destes para a dinâmica dos corredores. Partindo desse detalhamento, verificarmos as possibilidades de intervenções para a conformação de corredores ecológicos.

As possibilidades de intervenções foram testadas no Setor 1, que compreende a área de ligação entre a Serra da Cantareira e o Parque Juqueri, além do município de Caieiras; no Setor 2, na parte central do eixo principal, que inclui o trecho ligado ao Morro do Boturuna e todos os fragmentos ao redor; e no Setor 3, que está ao sul do eixo ligado ao Morro Grande.

A Faixa 1 foi selecionada por possuir boa parte de sua área protegida por instrumentos legais de conservação na esfera do poder público municipal. E também por estar relacionada diretamente ao Morro Grande, o que lhe confere uma característica diferenciada das demais.

A Faixa 3 foi selecionada para observarmos uma situação atual menos favorável, do ponto de vista ecológico, com sedes industriais, permitindo então avaliar possibilidades de recuperação e reversão do conceito de ocupação. Trata-se também de uma área que segue paralela e inclui a foz do Rio Barueri Mirim, além da foz do Rio Cotia e Barueri-Mirim, importantes de serem resgatadas para a dinâmica dos corredores.

\subsubsection{POSSIBILIDADES DE IMPLEMENTAC̦ÃO DO SISTEMA DE CORREDORES}

Buscamos definir as categorias de possibilidades de implementação seguindo a legenda proposta pelo zoneamento da RBCV, de forma que possam ser mais facilmente adaptadas ao modelo já utilizado pelo órgão público gestor da reserva. Assim, as Áreas de Transição e Cooperação foram marcadas em torno dos principais conflitos e barreiras; ou seja, ao redor de núcleos urbanos mais adensados, como Santana de Parnaíba, Caieiras e Vargem Grande Paulista, e ao longo das rodovias. Em torno de núcleos menos adensados e das áreas de transição entre pontos de conexão mais estratégicos, definimos algumas Áreas de Amortecimento. As áreas que representam possibilidades para a implementação dos corredores são as Áreas Núcleo Existente, as quais foram desenhadas 
sobre as Classes de Potencial de Condução de Fluxos Ecológicos 9, 8, 7 e 6, além de serem áreas com Alto e Muito Alto Valor Ecológico. Outras são as Áreas Núcleo Propostas, áreas com Classe de Potencial de Condução de Fluxos 5, 4, 3, 2, e com Alto Valor Ecológico. Já as mesmas classes, mas com Baixo Valor Ecológico, são as Áreas para Novas Possibilidades Estratégicas.

Definimos ainda as Áreas Vulneráveis, que, como já apresentamos, são aquelas não urbanizadas, em situações de risco para inundações e deslizamentos. As faixas indicativas secundárias não possuem Área de Transição devido ao fato de já possuírem um espaço restrito de áreas não urbanizadas e com mais probabilidades de conexões. As possibilidades de implementação do sistema de corredores são apresentadas nos Mapas 27, 28, 29, 30 e 31 a seguir.

Verificamos o potencial das faixas para viabilizar os corredores estruturais, ou seja, nos apropriamos da presença ou ausência de núcleos compostos por áreas abertas com valor ecológico, e de seu potencial para formar ou não um contínuo. Não podemos afirmar com exatidão que a fauna regional ganhará benefícios e em que medida, mas podemos inferir que os animais em áreas de conservação da região, com a implementação de corredores, terão abrigo, oferta de comida e água, possibilidade de deslocamento, acasalamento e de trocas gênicas.

O valor ecológico das Áreas Núcleo, como já dito, não repercute em benefícios apenas aos animais; são extensas as implicações de áreas abertas e da vegetação para áreas urbanas, como ofertas de espaços para recreação e lazer da população, melhorias climáticas, controle de enchente e deslizamentos de encostas, recarga de aquíferos, controle térmico, filtragem de partículas atmosféricas, embelezamento da cidade, dentre outros. Todos podem ser resgatados e promovidos por meio da implementação dos corredores ecológicos.

A seguir, caracterizamos cada categoria de possibilidade de implementação, que representa diretrizes gerais indicativas da capacidade do trecho estudado em funcionar como um corredor estrutural.

•ÁREAS NÚCLEO EXISTENTE: importantes para conservação da vegetação e fauna regional, bem como do sistema úmido, devem ser transformadas em áreas de conservação de categoria máxima, como parques estaduais e municipais de uso controlado, como também centros de pesquisa de recursos naturais, diversidade de biologia e em conectividade animal e fragmentação. São estas áreas que estruturam o eixo principal do sistema de corredores.

-ÁREAS NÚCLEO PROPOSTA: possuem alto valor ecológico, mas sem cobertura vegetal muito significativa, devendo, portanto, ser alvo de projetos de recomposição vegetal nativa agregados 
com áreas de recreação e lazer, como parques estratégicos que promovam e potencializem serviços ecológicos. Podem também ser utilizadas como áreas de agricultura familiar, turismo agroecológico, atividades educativas e promotoras de bem-estar e saúde. Recomendamos que as áreas lindeiras aos rios e córregos do trecho estudado sejam transformadas em parques contínuos, lineares, com múltiplas funções, tanto em áreas abertas como em loteamentos.

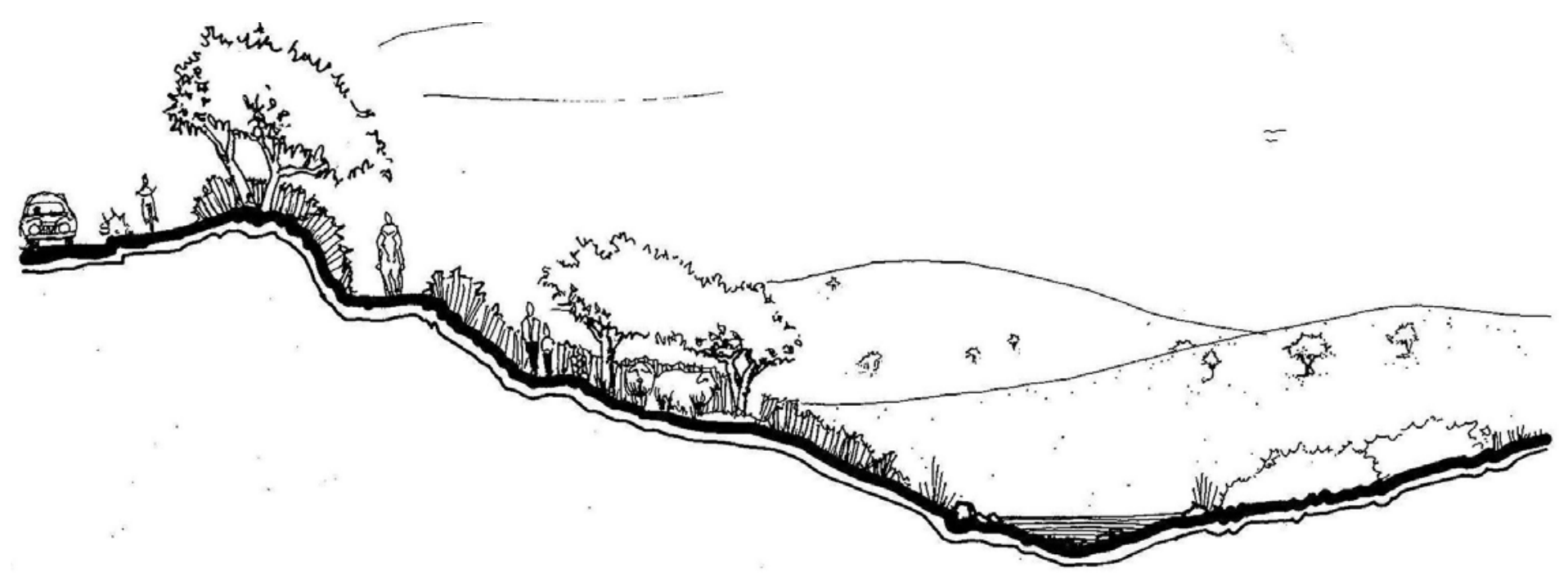

FIGURA 11: Exemplo de um uso em Área Núcleo Proposta, uma área de recomposição de APP, lindeira a um rio, em que a preservação do ecossistema e os processos ecológicos da fauna podem ser combinados com outros usos, como pastoril, recreação e lazer (FONTE: BLACK; DUI e TOBAR, 1991: 86). 


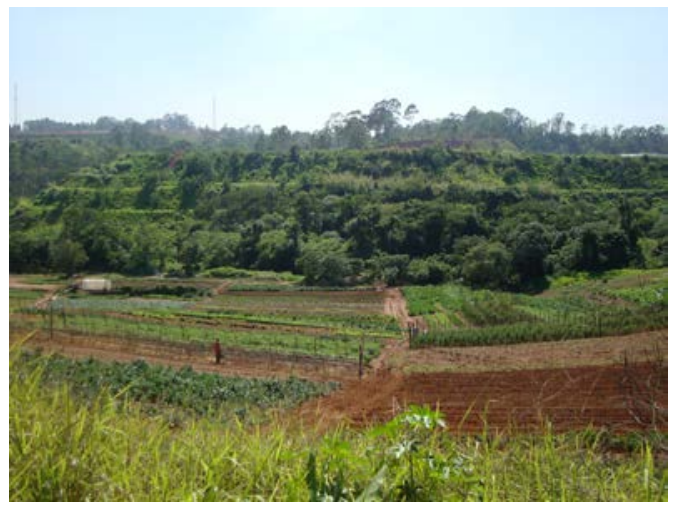

FOTO 39: Exemplo de situação que pode ser promovida nas Áreas Núcleo Propostas - presença dos fragmentos de vegetação junto com atividades de agricultura familiar. Estrada de São Fernando, Cotia -

SP (Foto: Julia Leite, 2011).

-NOVAS POSSIBILIDADES ESTRATÉGICAS : por se tratar de espaços abertos com baixo valor ecológico, estas áreas podem ter uso menos restritivo. Quando identificada localmente a necessidade do estabelecimento de conexões entre fragmentos florestais de menor tamanho, e quando possível, deve-se transformá-las em Áreas Núcleo Proposta; caso contrário, seriam indicadas para usos de baixo impacto, sendo a maior restrição quanto ao parcelamento do solo, o mais indicado nessas situações é de grandes glebas, recomendadas para campus universitário, uso residencial de baixa densidade, silvicultura e florestas urbanas para reter carbono.

FIGURA 12: Equipamentos e atividades educativas aproveitando trechos com valor ecológico,

paisagístico e cultural. São usos que podem ser atribuídos às Áreas de Novas Possibilidades Estratégicas (FONTE BLACK; DUI e TOBAR,1991: 56).

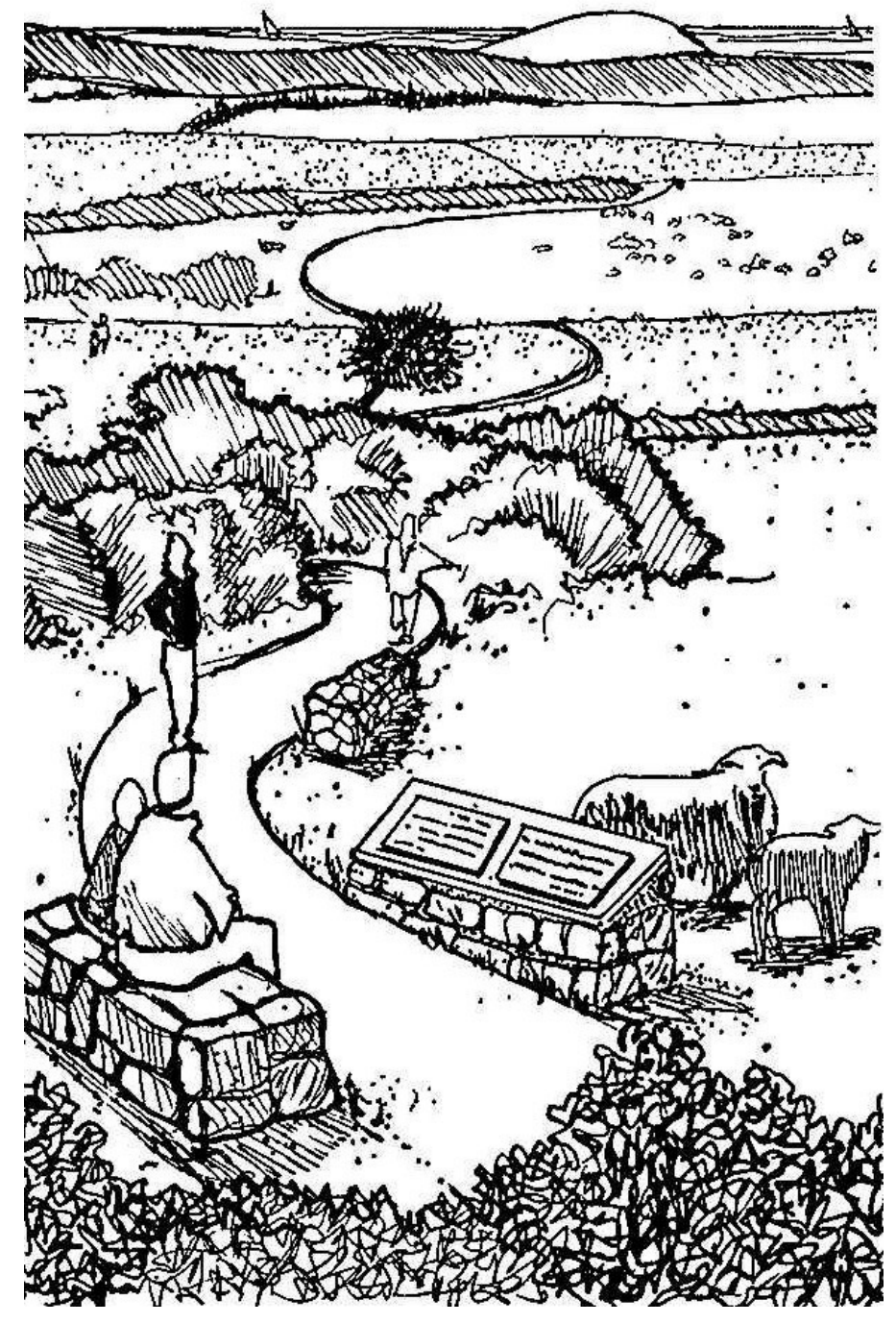




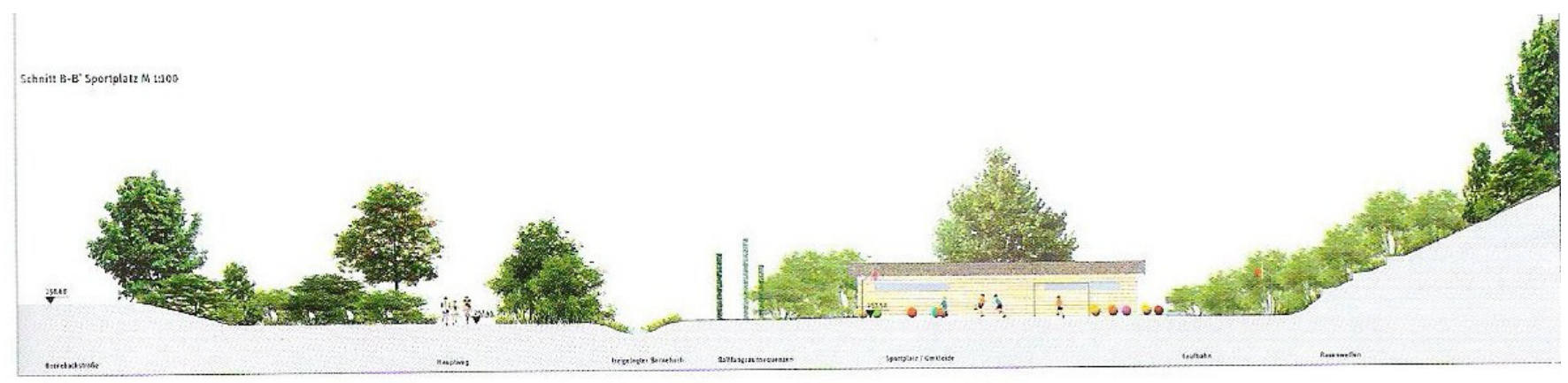

FIGURA 13: Detalhe em corte longitudinal do parque Königsquelle em Bad Wildungen,

Alemanha, em que equipamentos de lazer foram projetados em locais que não interferem na estrutura ecológica da paisagem, de maneira que a natureza foi preservada, serviços ecológicos importantes foram mantidos e criou-se um amplo espaço para recreação, educação e lazer. (FONTE: MERTENS, 2010:51).

-ÁREAS DE AMORTECIMENTO: próximas aos conflitos, estas áreas têm a função de amortecer impactos provenientes do uso urbano, especialmente regulamentar usos e ocupação do solo de menor impacto. Assim, devem ser utilizadas para bairros e núcleos urbanos de baixa densidade, com projetos de pomares, grandes praças e jardins, aumento de canteiros centrais de vias, como projetos de casas e edificios com tetos verdes, estacionamentos com pisos permeáveis. Também pode haver uso para silvicultura, florestas urbanas e agricultura familiar. Faixas localizadas sob linhas de alta tensão elétrica, ao longo de rodovias e linhas férreas, podem também ser tratadas como áreas de amortecimento e promover usos de lazer e recreação, como bicicletas e caminhadas.

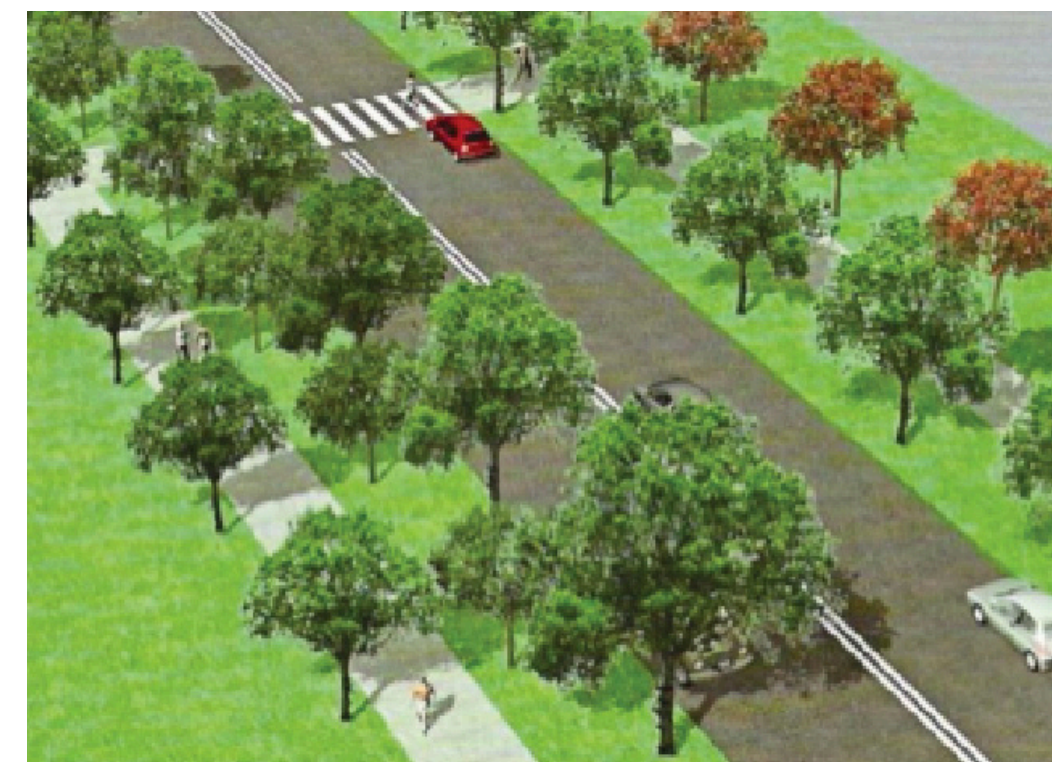

FIGURA 14: Detalhe do "Projeto para Espaços Abertos", bairro Khalifa City em Abu Dhabi, Emirados Árabes - desenho do escritório Neumann Gusemburger, de uma calçada com abundante arborização e piso impermeável vegetado, que ilustra como a Área de Amortecimento pode ser tratada em uma estrada ou avenida, em trechos onde a urbanização é menos densa, de maneira a ser menos hostil à avifauna urbana e minimizar, por exemplo, o calor e a insolação locais (FONTE: MERTENS, 2010: 135). 
- ÁREAS DE TRANSIÇÃO E COOPERAÇÃO: a ocupação é mais densa e deve ser planejada, mantendo e restabelecendo os elementos essenciais da infraestrutura verde, condicionados ao uso urbano, de modo a se marcar a coexistência entre o concreto e a vegetação. Devem ser promovidos projetos de praças, canteiros, drenagem urbana ecológica, bem como áreas de vizinhança para recreação e lazer.

-ÁREAS VULNERÁVEIS: pelo fato de a ocupação humana ser de risco nestas áreas, elas devem ser tratadas como Áreas Núcleo a Recompor, ou seja, terem seu uso restrito às condições do meio. 


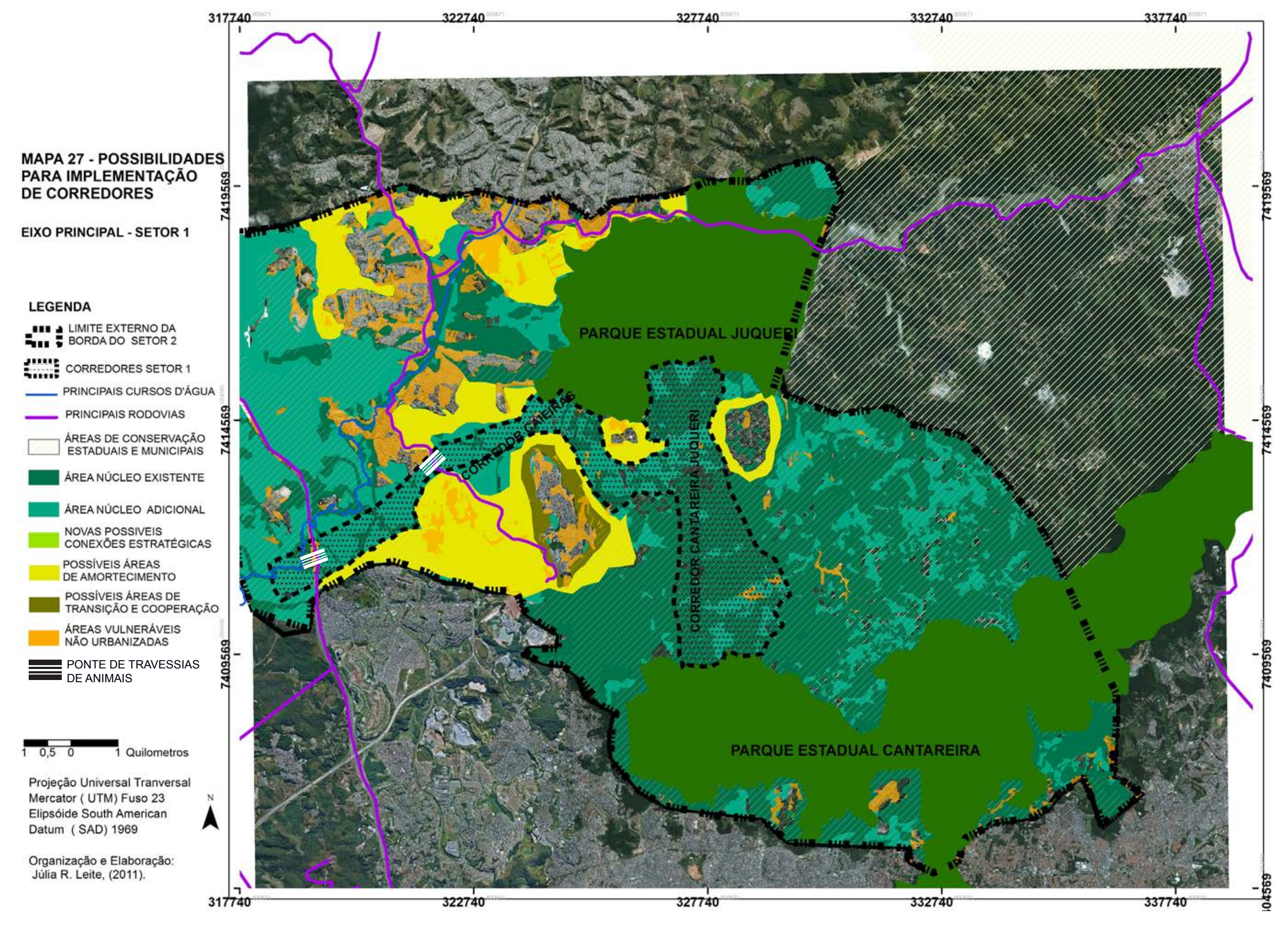


No Setor 1 do Eixo Principal, definimos dois corredores. O primeiro deles, Corredor Cantareira-Juqueri, mostrou-se com função para conectar os dois parques, não só estruturalmente, mas também, neste caso, podemos inferir, ter condições de promover deslocamento dos animais identificados na região. Isto porque o corredor possui a vantagem de estar numa área com fragmentos de vegetação, distante de núcleos urbanos adensados e próximo, apenas, de alguns loteamentos e chácaras. Assim, pode se tornar atrativo a espécies de mamíferos e aves mais especialistas e sensíveis aos distúrbios. (Mapa 27)

Definimos possíveis áreas de amortecimento em torno de alguns loteamentos, de maneira a garantir um controle do tipo de uso, evitando assim que o crescimento urbano restrinja as áreas núcleo do trecho delimitado. Sobre a totalidade de sua área, incidem instrumentos municipais e estaduais de proteção ambiental, que garantem sua adequação a um projeto desta natureza. A RBCV (Lino et al., 2009) possui uma menção a este trecho em seu zoneamento, em que destaca a importância de se conectar os dois fragmentos por meio de um corredor, além de preservar um trecho ainda não ocupado que vem sofrendo, frequentemente, pressões de ocupações.

O segundo corredor ecológico demarcado neste setor, o Corredor Caieras, só pode ser considerado ecológico se as diretrizes de criação de áreas de amortecimen to e de transição forem seguidas, bem como as de implementação de áreas núcleo adicionais, para restabelecimento de vegetação, além do tratamento adequado de uma ponte de travessia de animais sobre a Rodovia SP 332 (Mapa 27). Hoje, constatamos que existe o potencial estrutural de se estabelecer um corredor em tal trecho, já que o mesmo está localizado em uma área não ocupada e com valor ecológico alto.

A verificação mais precisa de quais espécies serão beneficiadas só poderá ser realizada por meio de estudos especializados de fauna e ecologia da paisagem.

Sabemos também que existem, sobre este corredor, interferências, pela proximidade, do núcleo urbano de Caieras e da rodovia, bem como a proximidade com a área urbanizada da zona Norte da cidade de São Paulo. 


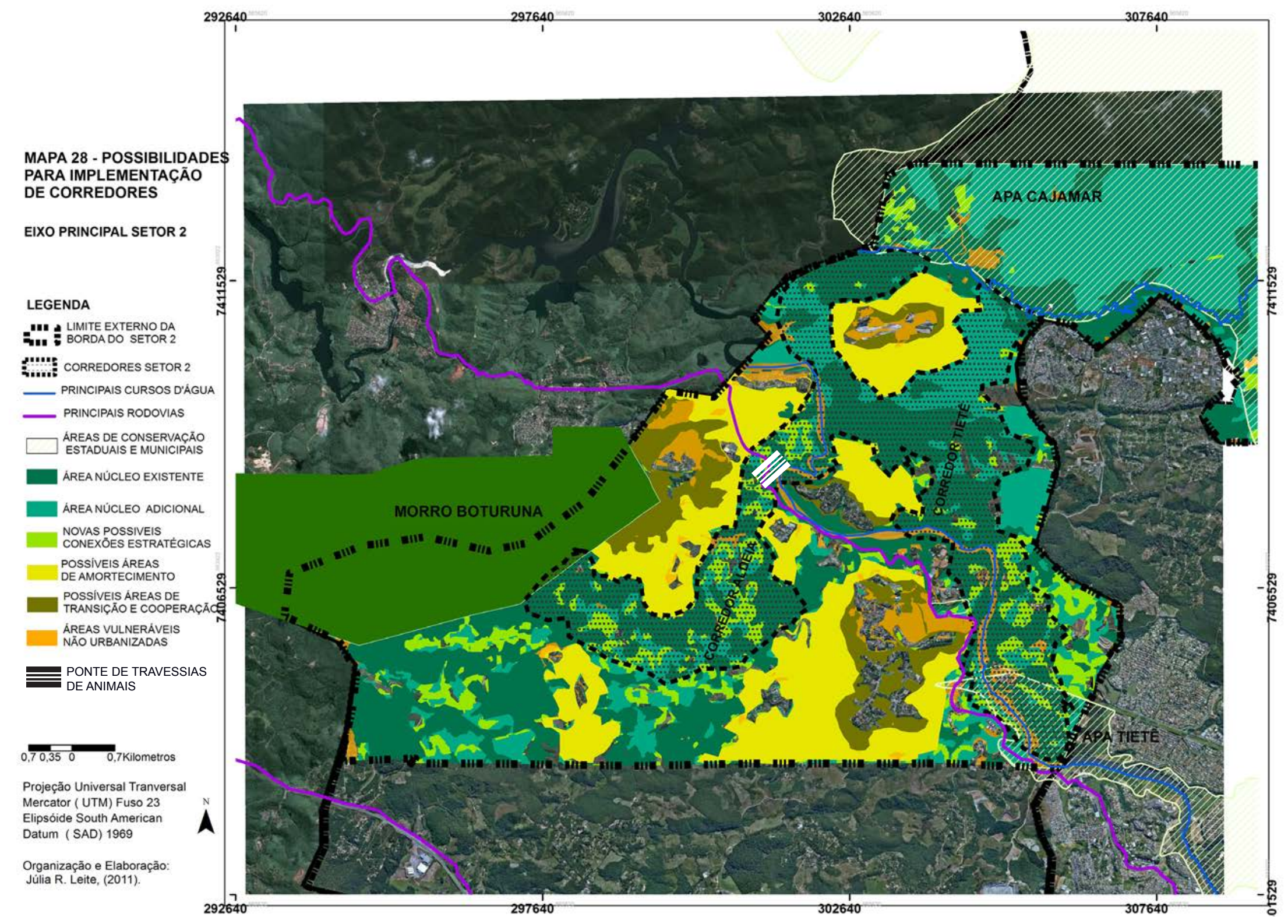


No setor 2 do Eixo Principal, identificamos duas possibilidades de corredores ecológicos, Corredor Aldeia e o Corredor Tietê(Mapa 28). Assim como em Caieiras, a viabilidade e manutenção deles está condicionada a medidas de controle e regulamentação da ocupação nas áreas marcadas como amortecimento e transição relacionadas aos núcleos urbanos de Santana de Paranaíba, bem como a passagem de travessia de fauna e faixas de amortecimento da Rodovia Castelo Branco.

O Corredor Aldeia ligaria o Morro Boturuna até a APA Cajamar, com a proposta de manter e restabelecer as áreas núcleo marcadas no Mapa 28, sendo que a travessia para animais é fundamental para que mamíferos com maior deslocamento possam se movimentar com segurança.

O Corredor Tietê, delimitado na outra margem da rodovia, serviria para conectar estruturalmente a APA Tietê à APA Cajamar, tendo também o importante papel, além de permitir a movimentação e o abrigo de animais entre as duas áreas de proteção, melhorar a qualidade ecológica da margem do Rio Tietê e, consequentemente, do próprio rio.

A proximidade do rio com a rodovia merece destaque e atenção, já que medidas de contenção de animais para a rodovia devem ser tomadas, como grades, de maneira que os animais que buscamos atrair e contemplar não acabem atropelados. 


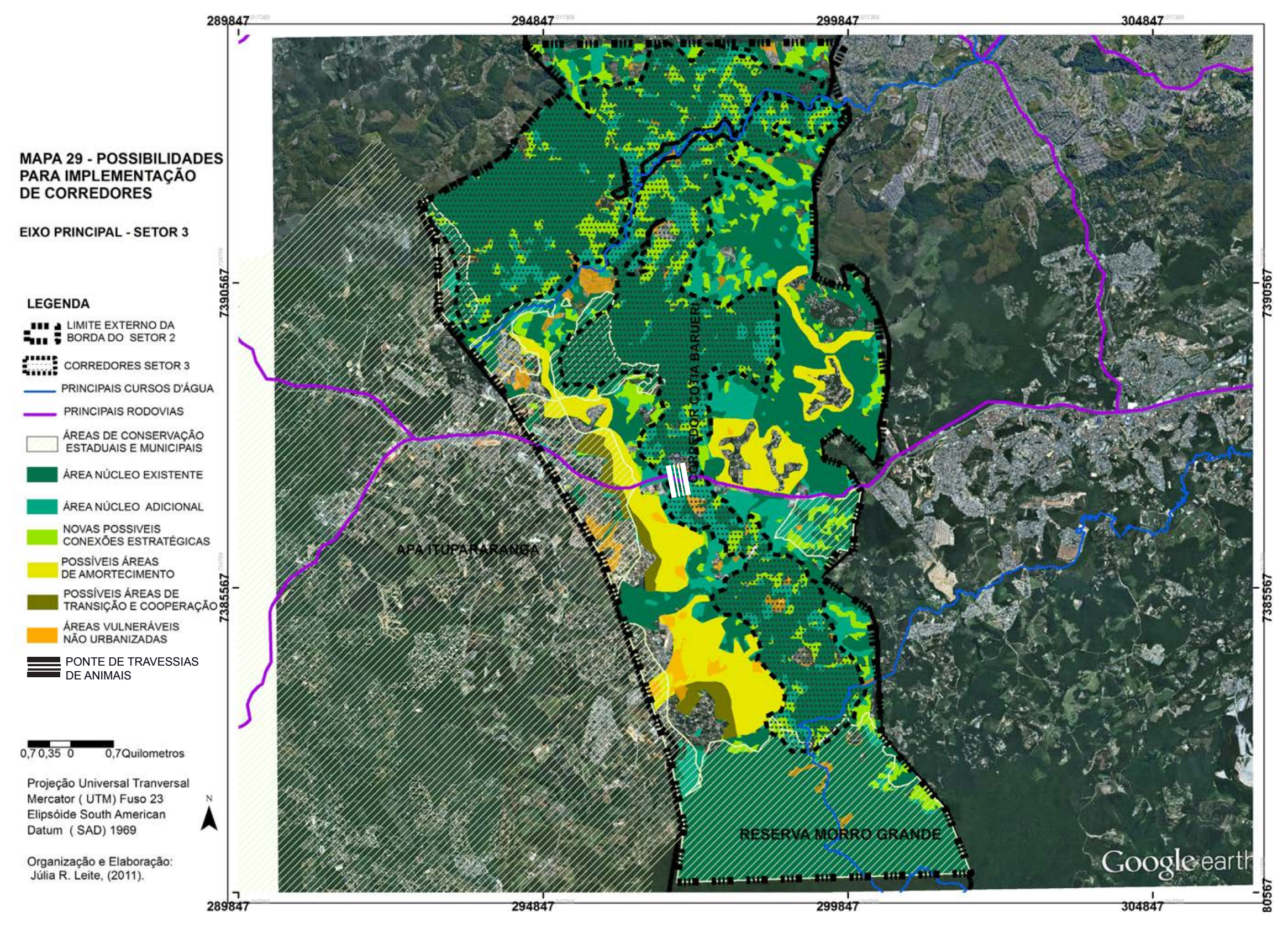


No Setor 3 não existe outra área de conservação além do Morro Grande, mas identificamos um grande fragmento de vegetação com alto valor ecológico localizado no município de Itapevi. Foi possível então estabelecer um corredor que conectasse ambos, denominado Corredor Morro Grande-Itapevi.(Mapa 29)

Porém, a pressão de ocupação oriunda do centro do município de Vargem Grande Paulista precisa ser controlada, de maneira que não se expanda sobre as áreas com valor ecológico do corredor. São necessárias propostas para as áreas de amortecimento e de transição, para que as conexões possam continuar a existir, bem como a criação de algumas áreas núcleo adicionais e uma travessia de animais sobre a Rodovia Raposo Tavares.

Propomos que o corredor seja prolongado para além do fragmento em Itapevi devido à proximidade com o Rio Itapevi-Mirim, de modo a se criar uma grande área de preservação de suas margens e do ambiente fluvial. O Corredor pode, portanto, a partir deste trecho, continuar com a conexão para o restante da área de abrangência, não tratada neste estudo.

É neste setor que ocorre a ligação com a Faixa Secundária Indicativa 1, promovendo mais uma conexão, que é entre o Eixo Principal e a Faixa Secundária 1, com bastante importância ecológica, como pode ser visto adiante. 


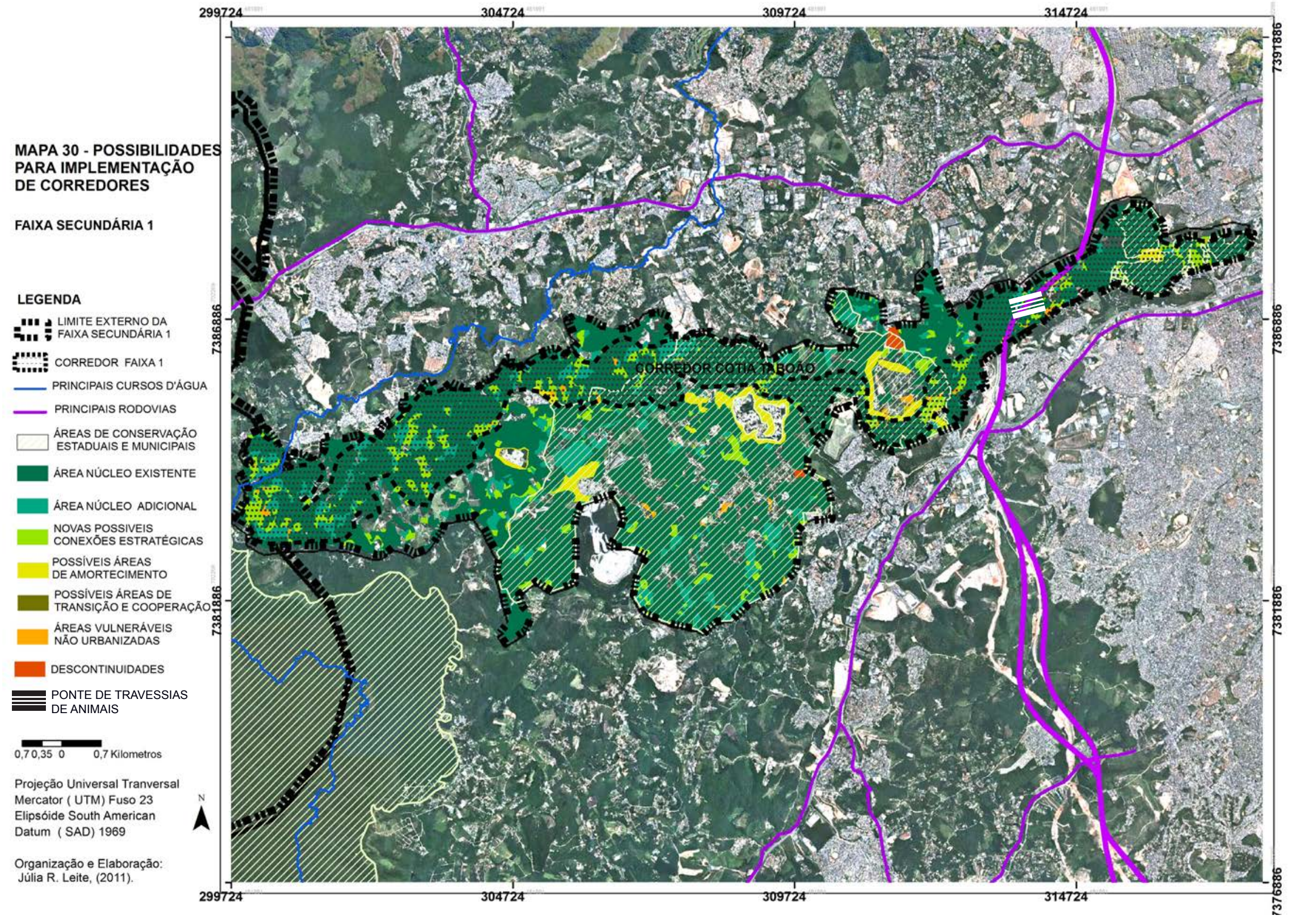


Na Faixa Secundária Indicativa 1 verificamos a possibilidade de conexões entre os fragmentos por quase todo seu o trecho, devido à presença de Áreas Núcleo Existentes. A proposta de algumas Áreas de Amortecimento foi feita para tentar amenizar conflitos decorrentes de alguns usos urbanos sobre áreas com valor ecológico.(Mapa 30)

Marcamos o corredor Cotia-Taboão ao norte da faixa por concentrar fragmentos de maiores valores ecológicos e estar mais distante dos loteamentos do interior da APA EMBU. No final do corredor, localizamos uma descontinuidade, devida a um núcleo urbano consolidado, a qual não permite a travessia de alguns animais, especialmente mamíferos. Entretanto, ainda é possível, por uma faixa bem estreita, manter a continuidade estrutural, com a implantação de uma travessia de animais e amortecimento do Rodoanel Mario Covas. A presença de áreas com alto valor ecológico e a conectividade estrutural verificada e constatada permitem inferir que a faixa pode atuar como corredor para espécies de animais, especialmente aves e alguns mamíferos, com potencial de ser tratada como área de interesse ecológico e ambiental.

Existem nesta faixa instrumentos de proteção ambiental municipal que devem ser mantidos e valorizados, de modo que consigam cumprir sua função de garantir os serviços ecológicos. 


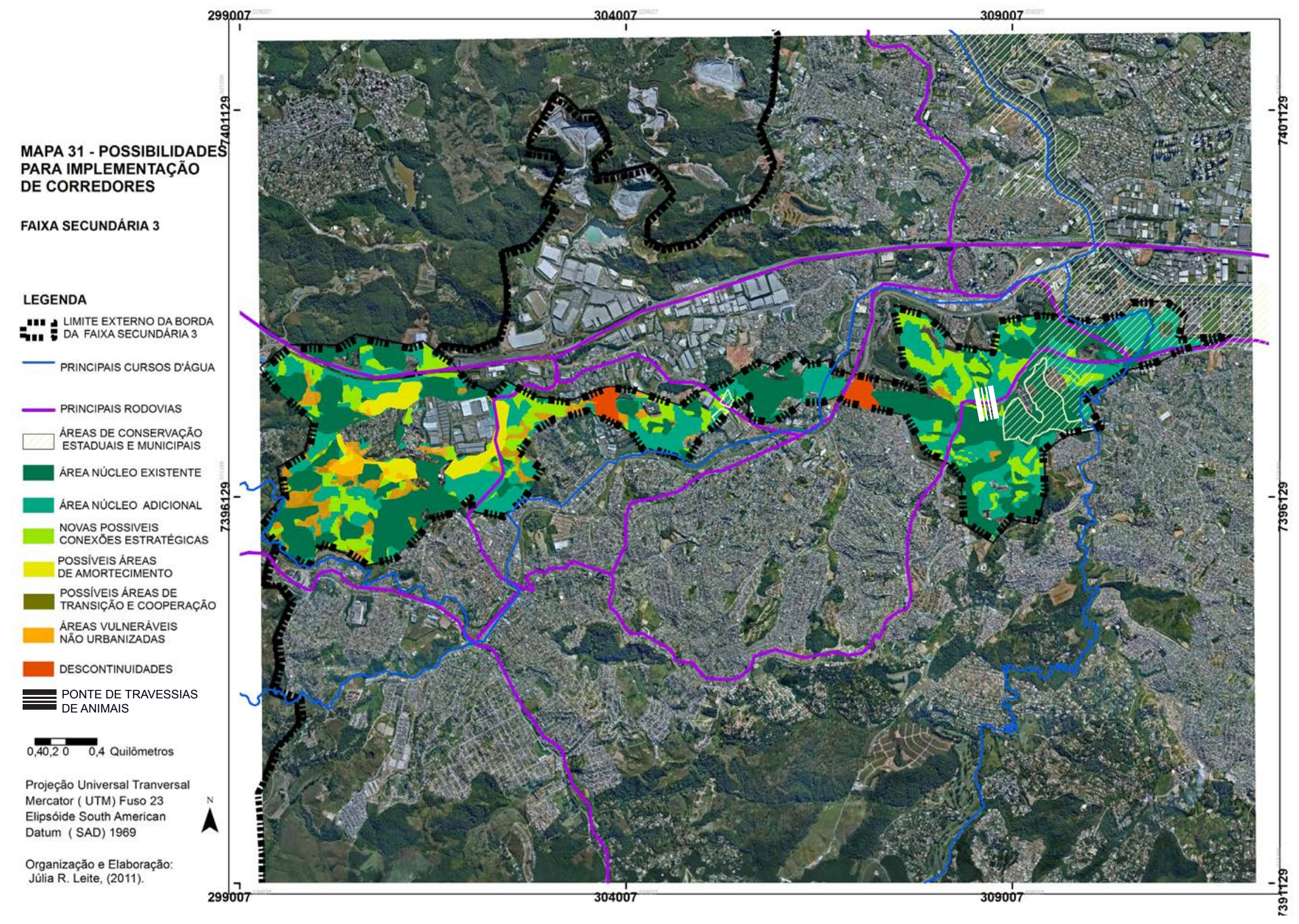


A Faixa Secundária Indicativa 3 possui uma área limitada, entre uma matriz urbana muito densa, com usos industriais no entorno e no interior da faixa, além de alguns núcleos urbanos em seu limite. Ainda assim, constatamos a possibilidade de implementação de Áreas Núcleo Existentes e Áreas Núcleos Adicionais capazes de configurar um corredor ecológico, que não poderá ser contínuo, e sim seguir o modelo de Trampolins Ecológicos.(Mapa 31) Isso porque existem descontinuidades devidas a núcleos urbanos consolidados e muitas rodovias, mas que podem promover beneficios e serviços ambientais, além de permitir abrigo e deslocamento para a avifauna urbana, de características e necessidades mais generalistas.

Pelo fato de se tratar de uma faixa com muitas rodovias que seccionam as áreas núcleo e interrompem fluxos de fauna, não recomendamos a implantação de pontes de travessia para animais sobre todas essas rodovias, já que, devido ao entorno e tamanho mais reduzido dos fragmentos Núcleo existentes não é esperado aqui o deslocamento de mamíferos e aves. Apenas recomendamos a implementação de uma ponte travessia no final da faixa, onde há um potencial maior de abrigo de animais, junto à foz do Rio Cotia e mais próximo ao Rio Tietê e da APA Tietê.

A Faixa Indicativa 3 representa uma situação muito interessante, caracterizada pela coexistência de Núcleos Existentes com valor ecológico, alguns com potencial de recuperação e com uma condição de urbanização densa, numa área da RMSP com escassez de parques urbanos e de áreas de lazer e recreação para a população.

Esta faixa, portanto, pelo seu contexto e características, adquire potencial de se tornar um contínuo de alguns parques e áreas de conservação com importante papel na regulação de fluxos hídricos, climáticos e de oferta de áreas para recreação e lazer. 


\subsubsection{INFRAESTRUTURA VERDE NAS ÁREAS DE CONFLITO E ÁREAS DE TRANSIÇÃO}

Mesmo em ambientes mais hostis, devemos propor a inclusão de elementos naturais, como vegetação e águas fluviais e pluviais, nos projetos de infraestrutura urbana.

Como exemplos de intervenções a núcleos urbanos que representam conflitos aos fluxos ecológicos (de modo geral), apresentamos a seguir tipologias de ruas e calçadas desenvolvidas no projeto realizado em 2009, "Natureza de Taboão da Serra" (FUSP/FAUUSP, 2009), sob coordenação técnica da autora desta tese com equipe multidisciplinar de consultores.

Um dos itens abordados pelo projeto foi "Vegetação Viária". A partir de dados de campo, definimos os principais conflitos e as deficiências do ambiente urbano e propusemos soluções para melhoria da vegetação viária e acessibilidade, como as tipologias Rua Jardim, Avenidas, Rua Parque e Rua APA. Tais exemplos, em uma cidade típica da RMSP como Taboão da Serra, servem para ilustrar a realidade dos núcleos urbanos abordada pelo sistema de corredores.

Para a elaboração das tipologias, nos fundamentamos em princípios e técnicas do conceito de infraestrutura verde. Trata-se de uma estratégia para identificação, valorização e aproveitamento dos serviços que a natureza pode realizar no ambiente urbano (CORMIER e PELLEGRINO, 2008). O sucesso de implantação e funcionamento dessas iniciativas em diversas cidades e regiões do mundo é, geralmente, acompanhado por uma série de beneficios socioeconômicos e ambientais.

De acordo com Pellegrino et al. (2006), a infraestrutura verde urbana pode contribuir nas funções de base estrutural e de integração da cidade, oferecendo soluções e estratégias simultâneas para: melhorar a circulação e as acessibilidades; garantir um espaço agradável para o passeio e a moradia; criar oportunidades de recreação para a população; complementar o sistema de drenagem e conduzir as águas urbanas com segurança; contribuir para a manutenção dos processos ecológicos e de sustentabilidade dos ecossistemas, garantindo a conectividade dos fragmentos naturais e incrementando a biodiversidade.

Algumas tipologias demonstram a intenção do projeto em amenizar o tráfego de automóveis e induzir a redução, em alguns trechos, das suas velocidades, com a ideia de criar ruas mais seguras e agradáveis para pedestres e ciclistas. Como exemplo, citamos os conceitos woonerf e de traffic calming (PRINZ, 1980).

Woonerf é um conceito urbanístico holandês aplicado em muitas cidades da Holanda e de 
outros países, com grande sucesso. Aqui, a rua passa a ser percebida como uma extensão do quintal das casas, sendo que os pedestres têm prioridade sobre os automóveis.

Já o conceito de traffic calming é caracterizado por um conjunto de estratégias e medidas que visa induzir à redução da velocidade e do tráfego de veículos, através da introdução de lombadas, lombofaixas (platôs), rotatórias, estreitamento de ruas, criação de ruas mais curvilíneas e sinuosas, canteiros centrais, proibição de veículos em algumas ruas, etc.

A utilização de técnicas de infraestrutura verde, como pisos permeáveis, biovaletas e canteiros de chuva, deve-se ao fato de essas estruturas urbanas, juntamente com a vegetação, serem capazes de diminuir o volume e a velocidade no escoamento de águas pluviais.

Os pavimentos permeáveis são superficies porosas ou perfuradas que permitem a infiltração de parte do escoamento superficial, previsto com relação à superfície impermeável dos passeios, como blocos vazados, intertravados, concregramas, que são assentados diretamente sobre o solo natural compactado e preparado para receber tais revestimentos. Trata-se de uma medida estrutural que pode ser utilizada em passeios, estacionamentos, quadras esportivas e ruas de pouco tráfego (TUCCI e et al, 1995).

Os canteiros de chuva são depressões topográficas criadas especialmente para receber o escoamento da água pluvial proveniente de áreas impermeabilizadas do entorno. O solo, geralmente tratado com composto e demais insumos que aumentam sua porosidade, age como uma esponja a sugar a água, enquanto microrganismos e bactérias removem os poluentes difusos trazidos pelo escoamento superficial. Com a adição de plantas, a evapotranspiração e a remoção dos poluentes aumentam. Além de sua capacidade de infiltração, um canteiro pode contar com um extravasador, calculado para o pico do fluxo de concentração de chuvas maiores que as consideradas em seu projeto (CORMIER e PELLEGRINO, 2008).

As biovaletas, ou valetas de biorretenção vegetadas, são semelhantes aos canteiros de chuva, mas correspondem a depressões lineares preenchidas com vegetação, solo e demais elementos filtrantes, que processam a limpeza da água da chuva, ao mesmo tempo em que aumentam seu tempo de escoamento, dirigindo este para os sistemas convencionais de retenção e detenção das águas (CORMIER e PELLEGRINO, 2008). 


\section{RUA JARDIM}

A Tipologia Rua Jardim foi desenvolvida para trechos de vias que têm como característica o uso residencial com edificações de baixo padrão construtivo, em lotes pequenos (em geral com 3-5m de frente). Os trechos, muitas vezes, estão incluídos em Zona Especiais de Interesse Social (ZEIS), por não terem ainda acesso à estrutura urbana, como rede de água e esgotos, rede elétrica, pavimentação nas ruas e calçadas. São frequentemente loteamentos irregulares e/ou áreas de risco (IPT, 2008).

Devido a essas características, no que se refere à arborização viária, muitos desses trechos possuem calçadas estreitas (menores do que 1,50m), o que impede o plantio adequado de arborização viária. Os passeios de veículos não são muito largos (em média $5,5 \mathrm{~m}$ ), dificultando o alargamento das calçadas, que, muitas vezes, são inferiores a $0,90 \mathrm{~m}$, sendo consideradas muito estreitas até para a passagem de pedestres.

Com relação aos pedestres, devido à inacessibilidade de veículos e ausência transporte público nos trechos, as ruas são muito utilizadas para o deslocamento das pessoas e também como áreas de lazer para jovens e crianças e também áreas de estar para os moradores em geral.

Devido a tais características, elaboramos três situações dentro dessa tipologia que se baseiam na concepção de via de leito único, ou seja, sem diferenciação em nível entre calçada e leito carroçável.

A situação A compreende os trechos onde existe tráfego de veículos. Se há garagens nas casas, há, portanto, a necessidade de locais para acesso e parada de veículos. As áreas exclusivas para pedestres e as de passagem de veículos devem receber pavimentação diferenciada por cores e materiais (Figura 16 - Situação A). Recomendamos o plantio de espécies arbóreas de médio porte nos "canteiros de chuva" implantados lateralmente, entre as calçadas e a rua, em lados intercalados, de acordo com a presença de entrada de veículos. Por meio desses canteiros, são criadas barreiras ao deslocamento em linha reta de veículos, o que faz com que a velocidade deles seja controlada, minimizando os conflitos com os pedestres. Com a implantação dos canteiros laterais, além da possibilidade de plantio de vegetação arbórea e herbácea, são também criadas áreas com equipamentos de estar com bancos (Figura 16- Situação A).

Quando as condições se apresentam muito estreitas, em geral com menos de $0,70 \mathrm{~m}$, sendo impossível o plantio de árvores, recomendamos, quando possível, o plantio de espécies vegetais trepadeiras em canteiros pequenos $(0,30 \mathrm{~m}$ x $0,40 \mathrm{~m})$ nas divisas de lotes (Figura $16-$ Situação A). 
TIPOLOGIA 2 - RUA JARDIM

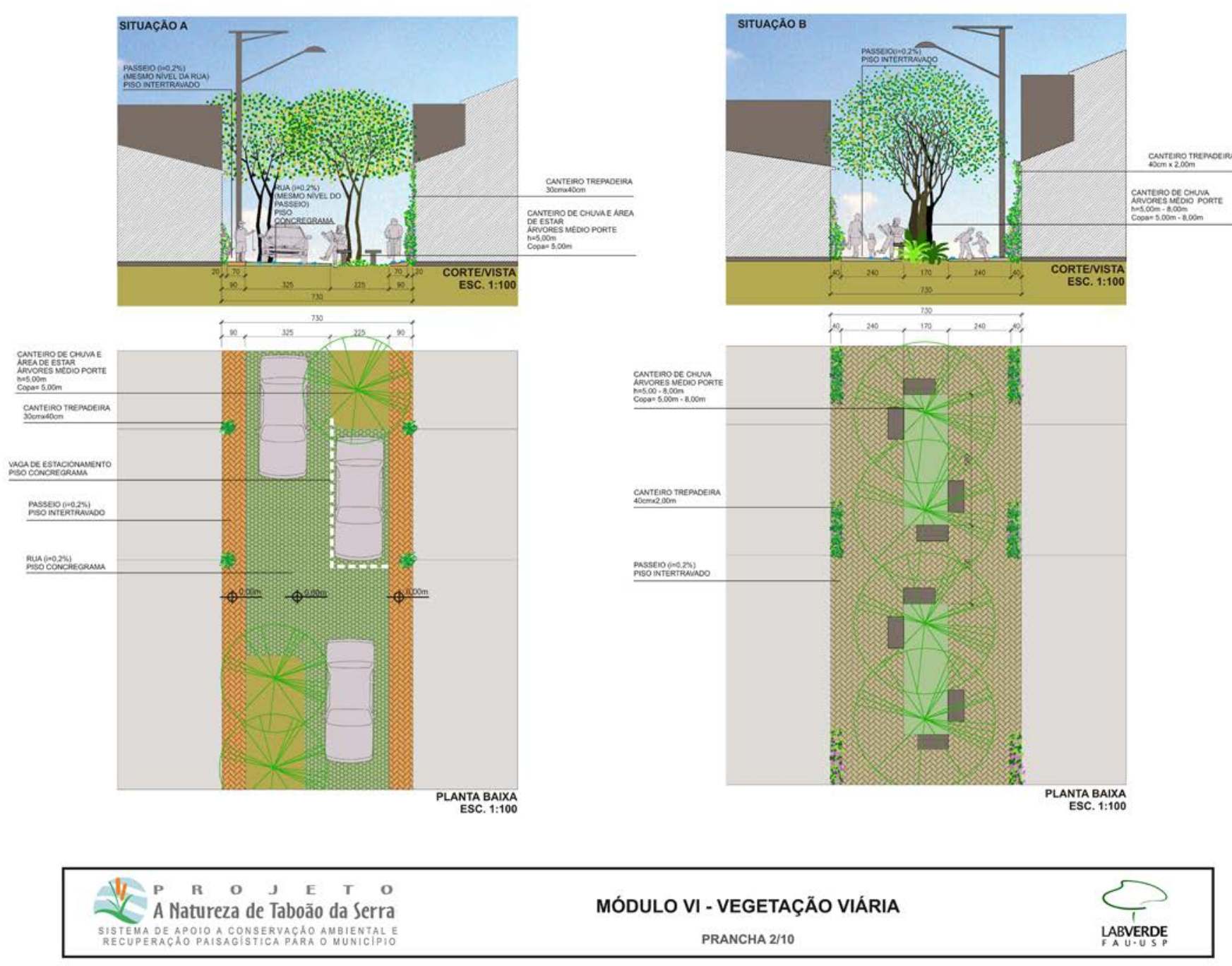

FIGURA 16: Exemplo de Infraestrutura Verde para minimização de impactos para a fauna urbana e melhorias ambientais para a população. Tipologia de Rua Jardim. Fonte FUSP/FAUUSP, 2009. Coordenação técnica da autora. 


\section{AVENIDAS}

A Tipologia Avenidas foi pensada para ruas e avenidas com canteiro central.

Em geral, o uso do solo nesta situação é misto com atividades comerciais e uso residencial. O fluxo de pedestres e veículos é intenso, com trânsito de ônibus e caminhões. As ruas são largas e a presença do canteiro central garante um espaço para o plantio de vegetação arbórea.

Recomendamos então que esse canteiro seja transformado em uma biovaleta contínua, onde sejam plantadas árvores de grande porte (Figura 17); e também que os leitos carroçáveis das ruas nesta situação tenham uma leve inclinação no sentido da biovaleta, para que haja o direcionamento e encaminhamento das águas pluviais.

Quando as calçadas das ruas nesta tipologia se encontrarem sob fiação elétrica, indicamos o plantio de espécies arbóreas de porte pequeno em canteiros localizados nas calçadas, seja em divisas de lotes, quando houver guias rebaixadas, ou, quando não houver, defronte a muros e gradis. Sugerimos que os canteiros de plantio das árvores sejam cobertos por arvoreiras e que as calçadas tenham revestimento de bloco de concreto intertravado.

Também é possível, quando necessária, a criação de áreas para estacionamento de veículos com revestimento de concregrama nos lados das ruas laterais às calçadas.

FIGURA 17: Exemplo de Infraestrutura Verde para minimização de impactos na fauna urbana e melhorias ambientais para a população. Tipologia de Avenida. Fonte: FUSP/FAUUSP, 2009.

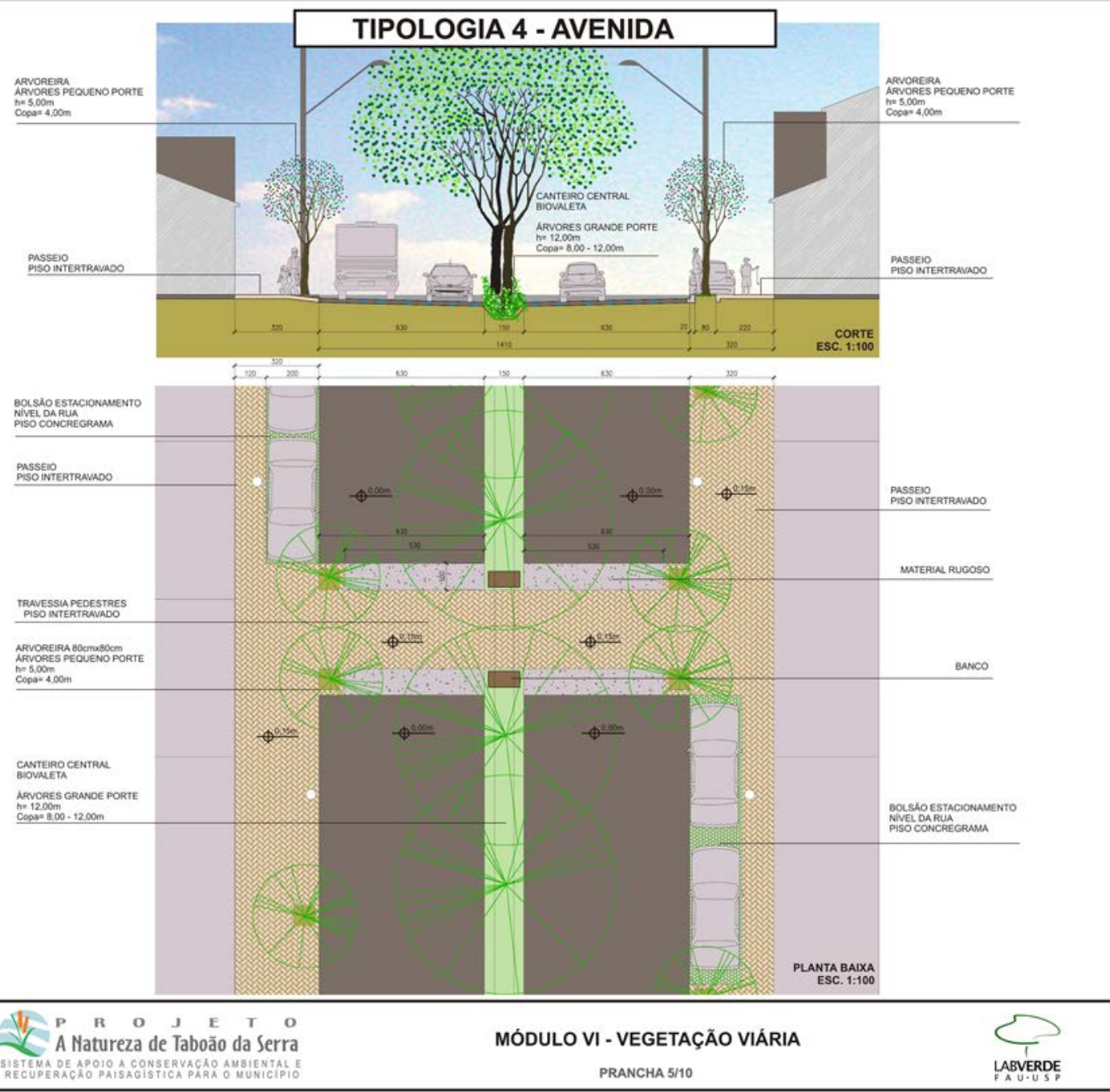

Coordenação técnica da autora. 


\section{RUAS PARQUE}

A Tipologia Ruas Parque foi pensada para aplicação nas ruas de uso local que acompanham córregos de pequeno porte e tributários ainda com margens não construídas, que mantenham trechos de faixas de vegetação ciliar em Área de Preservação Permanente (APP).

Sugerimos que sejam criados canteiros de chuva, aproveitando-se do alargamento das calçadas, para o plantio de vegetação arbórea de médio porte, criando bolsões que confiram à Rua Parque uma sinuosidade adequada para a redução da velocidade do tráfego e aumento da segurança dos pedestres, ampliando a possibilidade de arborização viária (Figura 18). Os canteiro devem ser implantados nos trechos da calçada em que não exista guia rebaixada, para que não haja interferências entre as árvores e as garagens. Nos locais com entrada de veículos, podem ser implantados canteiros de chuva, desde que sejam feitas "pontes" para essa passagem. Sugerimos, ainda, que o pavimento das calçadas seja de piso intertravado.
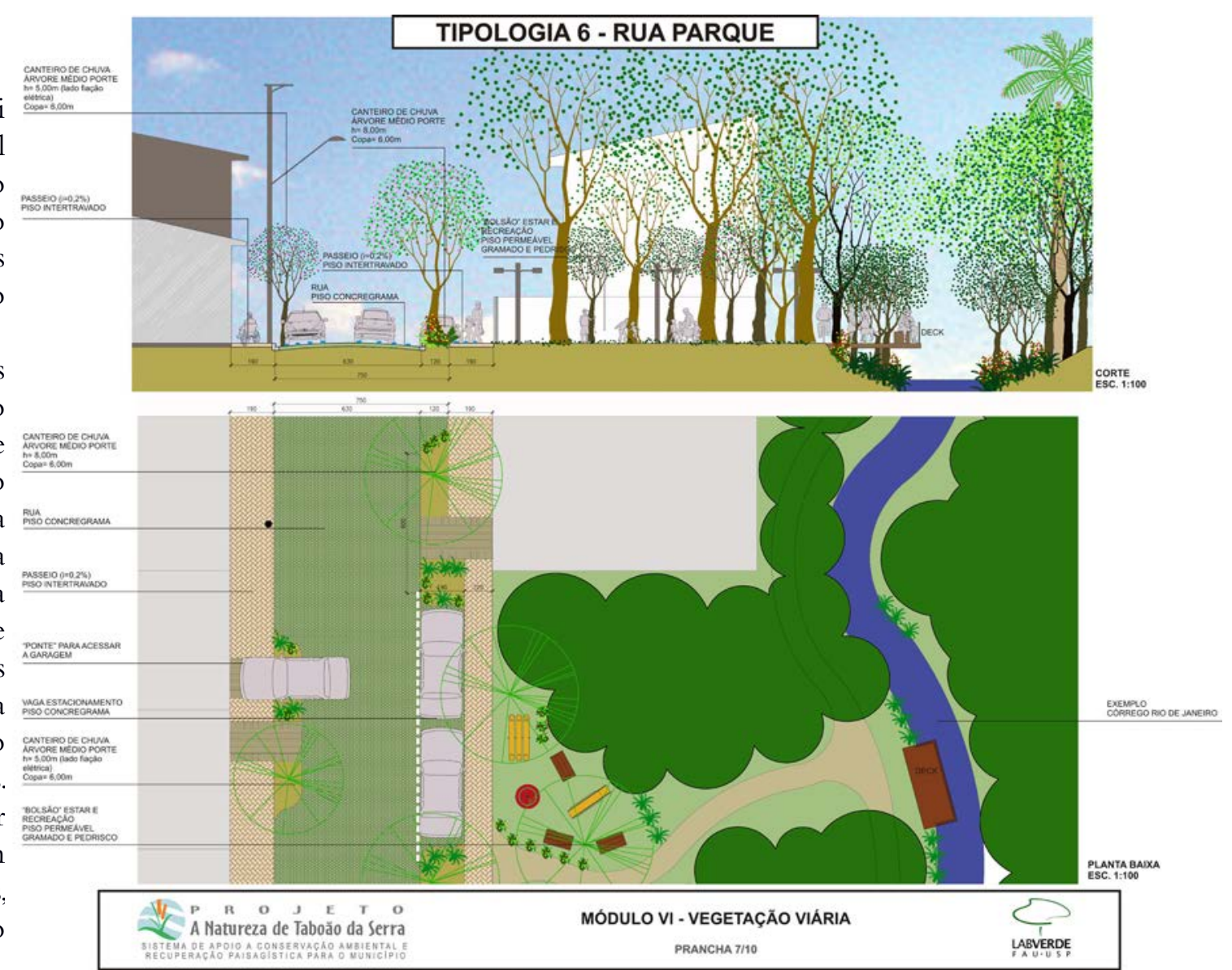

Esta tipologia de rua, com sinuosidade para manter a baixa velocidade dos automóveis, permitirá o uso simultâneo para circulação e para lazer, como ciclismo, patins, skate e jogos. A pavimentação do leito carroçável deverá procurar alternativas ao asfaltamento, dando preferência a revestimento de pisos mais rugosos e permeáveis, como blocos de concreto intertravado com vagas de estacionamento em concregrama.

Na situação de inserção ou proximidade com a área de APP, esta deve ser integrada aos passeios e sua arborização, ampliando sempre que possível, criando espaços de estar e recreação.

FIGURA 18: Exemplo de

Infraestrutura Verde para minimização de impactos para a fauna urbana e melhorias ambientais para a população. Tipologia de Rua Parque. Fonte: FUSP/FAUUSP, 2009. Coordenação técnica da autora. 
A Tipologia Rua APA descreve características de ruas, estradas e avenidas lindeiras a Áreas de Proteção Ambiental ou que tenham sido classificadas como de interesse ambiental.

Para as ruas que contornam fragmentos com essas características, recomendamos que seja aproveitada a proximidade com a mancha de vegetação para a criação de bolsões de lazer e estar, com equipamentos de ginástica e recreação.

Sugerimos que, nas manchas de vegetação, sejam efetivadas ações de recomposição vegetal com espécies nativas (Figura 19).

Ao longo dos fragmentos, recomendamos a implantação do passeio de pedestres com revestimento de piso intertravado, levemente inclinado no sentido da biovaleta e em seguida a implantação de uma ciclovia, com o mesmo tipo de piso.

Ao lado de toda a ciclovia, pode ser implantada uma biovaleta contínua, com o plantio de espécies arbóreas de grande porte), evitando o escoamento superficial do entorno para dentro da APA

A rede elétrica, quando possível, deverá ser subterrânea, de maneira a evitar conflitos com a circulação de pessoas e com a vegetação.
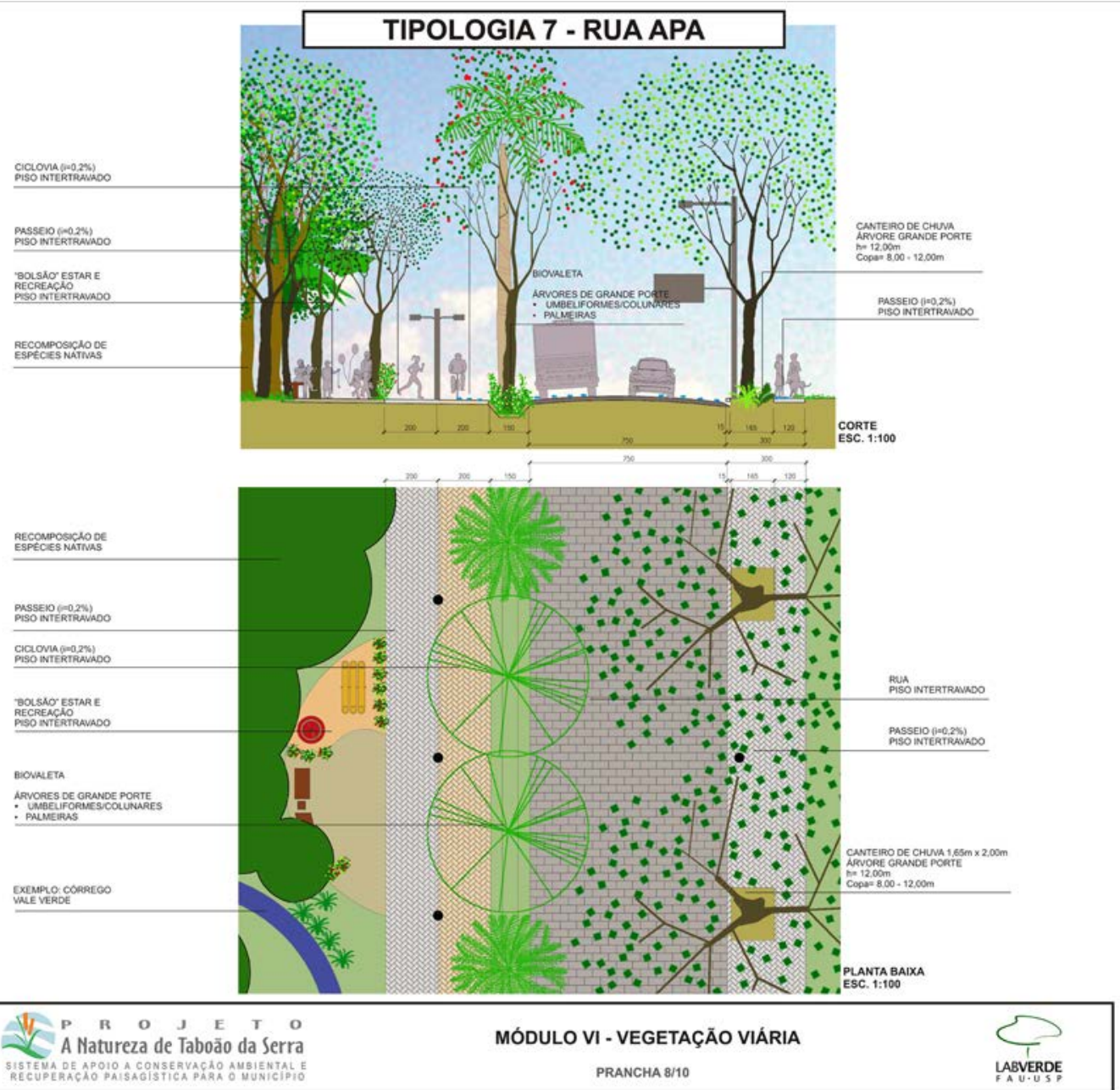

FIGURA 19: Exemplo de Infraestrutura Verde para minimização de impactos para a fauna urbana e melhorias ambientais para a população. Tipologia de Rua APA. Fonte: FUSP/FAUUSP, 2009.

Coordenação técnica da autora. 
Dentro das possibilidades do sistema aqui estudado, outro exemplo de solução específica que pode favorecer os fluxos ecológicos, para aves, fluxos hídricos e manutenção da vegetação, é a transformação de grandes estacionamentos, como o existente no paço municipal de Barueri, em áreas de absorção de águas pluviais, permitindo a recarga do sistema hídrico profundo e diminuindo o risco de inundações. Neste caso especificamente, traria mais benefícios pela localização sobre o Rio Itapevi, que hoje se encontra tamponado. A proximidade deste trecho com a foz do Rio Itapevi e Rio Cotia indica que, além de tratamento para o piso, seria uma oportunidade de renaturalizar as áreas, por meio de tratamento paisagístico e de recomposição vegetal, inclusive enriquecendo a flora e fauna local e, se direcionado, contribuindo para minimizar a poluição existente na água, por meio da implantação de espécies vegetais biofiltradoras.

Os loteamentos residenciais novos e em construção poderiam ter também áreas destinadas à contenção e absorção de águas pluviais, como estacionamentos, passeios e praças, bem como áreas verdes comuns, integradas, de maneira a promover os contínuos necessários para o sistema de corredores. Construção de tetos verdes em casas e edifícios pode também trazer benefícios.

\subsubsection{MEDIDAS MITIGADORAS SOBRE OS IMPACTOS DE RODOVIAS PARA A FAUNA}

Passagem de fauna por meio de passarelas, com instalação de redes altas para evitar a saída dos animais, mostrou ter sua funcionalidade bastante questionável, especialmente quando não há um planejamento que considere sua melhor localização em relação à via e ao contexto paisagístico. As passagens de animais junto a córregos e rios canalizados mostraram ser, em geral, muito positivas (GRILO, 2011).

Numa revisão de alguns trabalhos de ecologia de estradas, constatamos que as medidas mitigadoras de atropelamentos recomendadas são as passagens de fauna, geralmente sob estradas (DORNAS et al., 2011; LEITE et al., 2011; SOUZA e ANACLETO, 2011), em conjunto com as cercas para indicar passagens, lembrando que as mesmas devem ter manutenção, de modo a não causarem mais atropelamentos. Passagens aéreas compostas por cordas ou mangueiras para as espécies arbóreas aumentam a conectividade do habitat em áreas com margens florestadas.

A construção de passagem de fauna vem sendo discutida em função da resistência de animais 
ao seu uso, custos e impactos que causa; entretanto, alguns autores a recomendam como medida para conectividade entre fragmentos (BORGUI et al., 2011). Barreiras acústicas têm também sua utilidade para afugentar de rodovias, especialmente, espécies de corujas (GRILO 2011).

Outras medidas são também citadas pelos mesmos autores, como os reguladores e radares de velocidade dos veículos, sinalização nas estradas, educação ambiental sobre a importância da fauna e fiscalização e manejo da paisagem no entorno da estrada.

Mesmo não tendo a mesma utilidade para todas as espécies, as passagens de fauna são capazes de beneficiar alguns grupos de animais (HILTY et al., 2006). Para ilustrar a concepção geral de passagens de fauna, apresentamos duas ilustrações de rodovias na América do Norte que mostram dois tipos: as subterrâneas e as que são pontes de travessia.

De modo geral, quanto mais parecido ao seu habitat natural, mais fácil será a utilização pela fauna. Nos casos norte-americamos, os alces e ursos marrons se favorecem com grandes pontes, com muita luz e visibilidade, enquanto os ursos negros e pumas procuraram túneis apertados. Anfibios usam passagens frescas e sombreadas, como bueiros com água corrente, enquanto os roedores necessitam de coberturas para se esconder de predadores. Como resultado, a maioria das travessias é construída para um animal específico. Entretanto, um estudo recente realizado por Patrícia Cramer, ecologista da Universidade Estadual de Utah, descobriu que 68 de 70 cruzamentos foram utilizados pelos animais, desde peru selvagens a panteras. Esta informação reforça ainda mais a importância da passagem para os animais ${ }^{40}$.

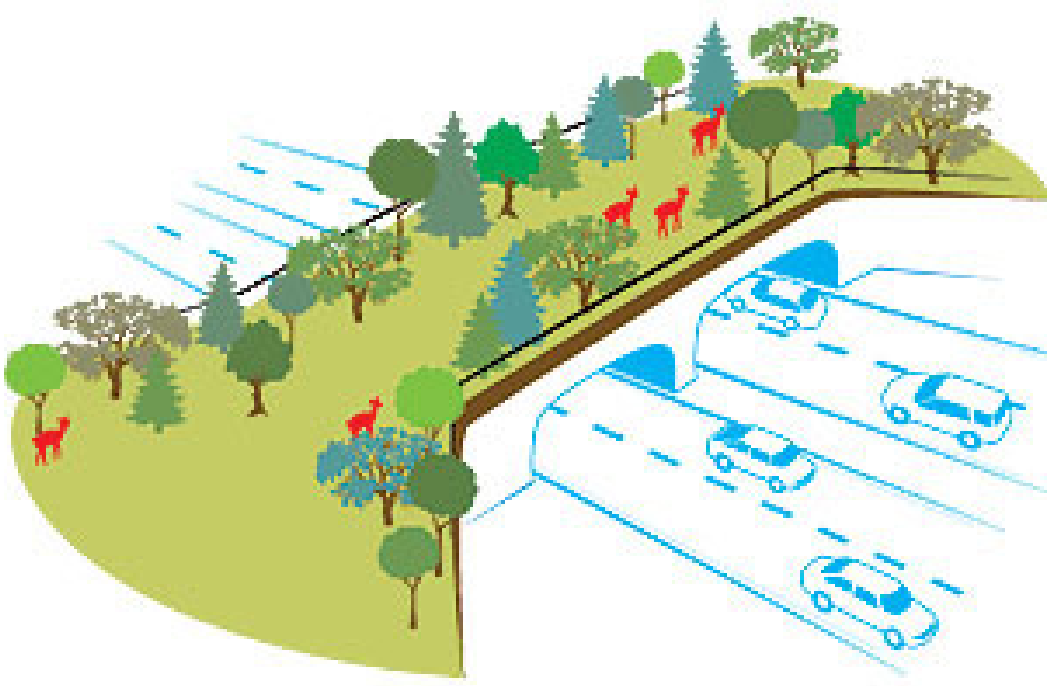

${ }^{40}$ Informações obtidas no site http://www. backpacker.com/june_2008_phenomenon_ wildlife_crossings/nature/12456. Acessado em 20/2/2012:

FIGURA 20: Ilustração de ponte de travessia pra animais sobre rodovia. Informações obtidas em http://www.backpacker.com/june_2008_ phenomenon_wildlife_crossings/nature/12456. Acessado em 12/02/2012. 
No Parque Nacional Banff, em Alberta, no Canadá, foram construídas vinte e duas passagens subterrâneas de animais e duas pontes de travessias (HILTY et al., 2006), como tentativa de reduzir o número de acidentes envolvendo animais e pessoas ao longo da rodovia Trans Canadá. Tem sido um processo longo, e os pesquisadores ainda estão estudando a eficácia dessas estruturas. Em um estudo sobre a eficiência dessas passagens, constatou-se um resultado melhor do que o esperado. Entre 1996 e 2001, pesquisadores registraram 32.518 passagens em várias dessas estruturas, número que não representa animais individuais, mas sim travessias, sendo que um único animal pode fazer diversas travessias.

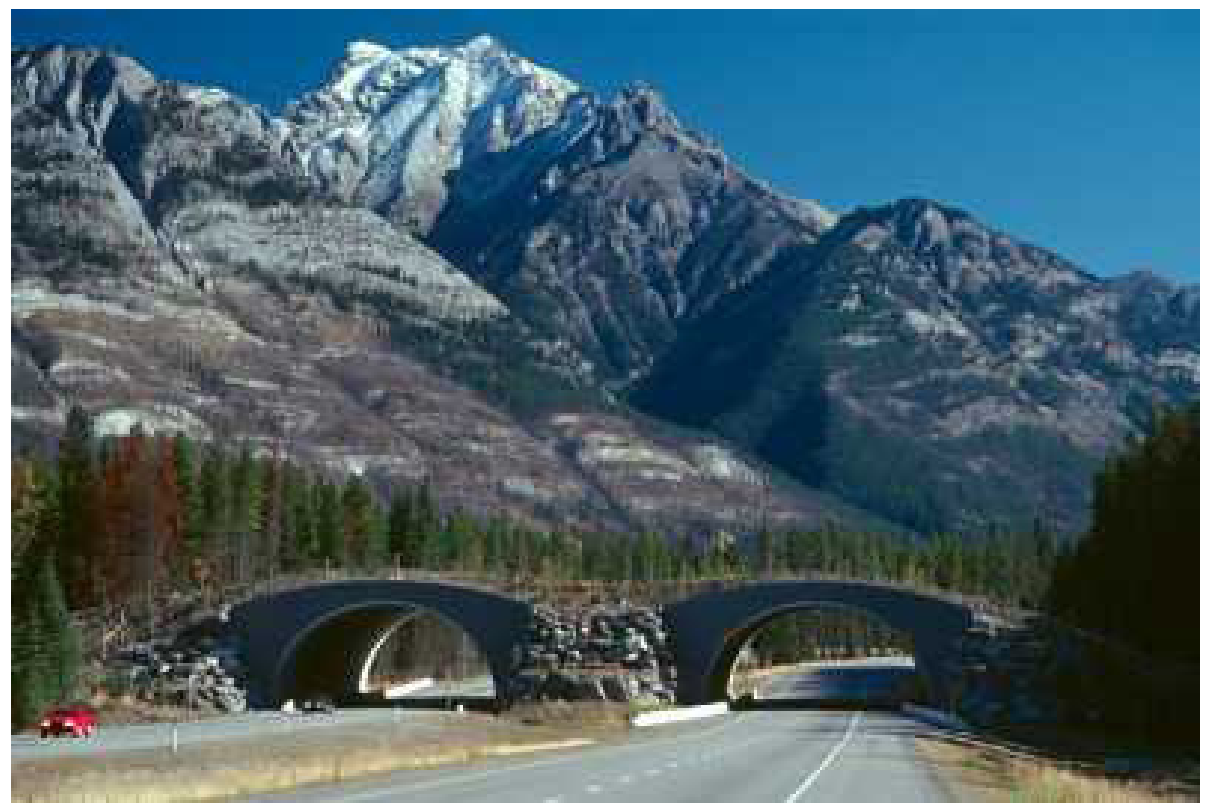

FIGURA 21: Ponte de travessia para animais, Bannf National Park, Alberta, Canadá. Informações obtidas em: http://www.mountainnature.com/articles/CrossingStructures. htm. Acessado em 12/2/2012: 
Outro exemplo é a ponte travessia para animais, na Rodovia 26, Alemanha, A passagem aqui representa um corredor de vida selvagem que permite aos mamíferos acesso com segurança a ambos os lados da autoestrada. O viaduto habitat possui cercas laterais para reduzir o ruído da estrada e as luzes. Rochas foram colocados nas extremidades da passagem superior para impedir o uso de veículos.

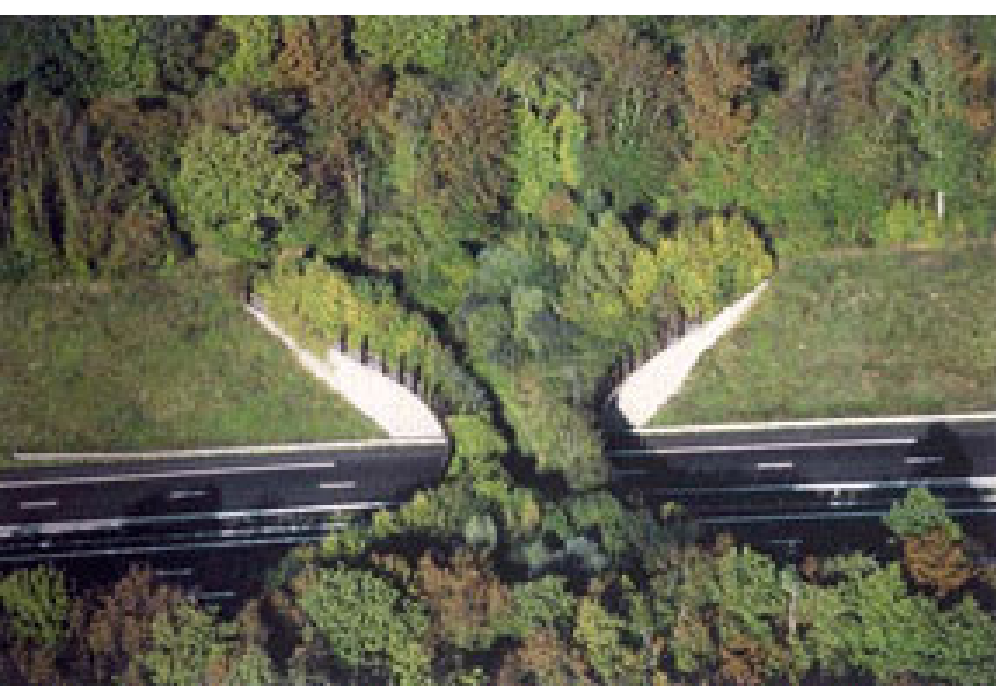

FIGURA 22: Ponte para Travessia de Animais 26 Motorway na Hardt Forest, Alemanha. Informações obtidas em: http://graemelaidlaw.wordpress.com/ .Acessado em 15/3/2012

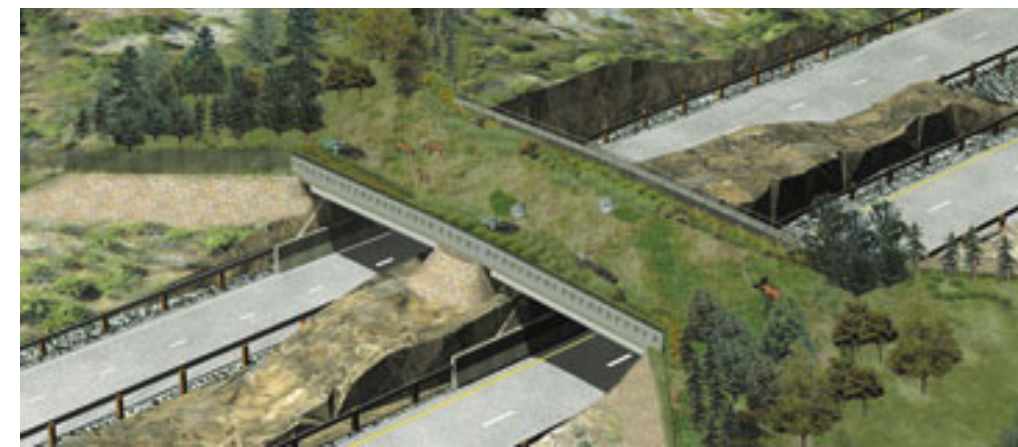

FIGURA 23: Ponte para travessia de animais sobre a Rodovia 69 Ontario Canadá. Disponível em http://dcnonl.com/article/id43072. Acessado em 05/03/2012.

Outro exemplo é a ponte de travessia de animais que está sendo construída também no Canadá, na Rodovia 69, em Ontário (Figura 23). Trata-se de uma estrutura feita de concreto, apoiada sobre um corte numa rocha, aproveitando-se da topografia do terreno. Com 30 metros de largura, foi construída em uma área onde houve um grande número de colisões envolvendo grandes animais. Foram então instaladas cercas para impedi-los de fazer a travessia fora da ponte e para indicar o percurso adequado. Outros recursos destinados a incentivar o uso pelos animais incluem: trabalhar alterações no entorno de maneira gradual e sutil, para não afugentar os animais: tratamento paisagístico que coincide com o ambiente natural adjacente natural e muros de concreto para evitar ruídos e impactos leves de veículos que circulam sob a ponte. 
Assim, finalizamos o último capítulo desta tese reafirmando que, para o estabelecimento de corredores ecológicos que priorizem fluxos ecológicos no contexto metropolitano, e a manutenção de seus inúmeros beneficios, a melhor estratégia está em elaborar projetos que invistam na minimização dos conflitos dos usos e redes infraestruturais urbanas e seus impactos nas áreas com alto valor ecológico.

Não podemos tratar os recursos naturais em tal setor apenas objetivando a criação de novas áreas de conservação. São necessárias reformulações dos princípios norteadores dos projetos de infraestruturas dos núcleos urbanos para que estes incorporem princípios ecológicos em seus partidos de desenvolvimento, incluindo soluções mitigadoras e de infraestrutura verde, e também nas áreas passíveis de serem tratadas como de transição e amortecimento. Só assim as áreas a serem destinadas à conservação e condução dos fluxos ecológicos conseguirão desempenhar seu papel neste quadro.

Portanto, além das possibilidades aqui verificadas de configuração dos próprios corredores ecológicos, a idéia da infraestrutura verde para as áreas urbanas, como de transição e amortecimento, pode fornecer importantes contribuições para um desenho ecologicamente mais eficiente da cidade, com maior sustentabilidade urbana e minimização dos impactos sobre os corredores ecológicos adjacentes.

Os exemplos citados de implementação dos corredores no setor Oeste da RMSP reservam para estes espaços abertos e vegetados a possibilidade de exercerem várias outras funções, como conectar fragmentos de vegetação, conduzir as águas com segurança, oferecer melhorias microclimáticas e atender usos relacionados à moradia, educação, ao trabalho e lazer. Com isso, garantimos maior segurança social, acomodando as funções das demais infraestruturas urbanas, como transporte e abastecimento, além de atender aos objetivos mais tradicionais de recreação e melhorias ambientais e estéticas. 


\section{CONCLUSÕES}

A partir do entendimento do contexto paisagístico regional e da seleção de faixas de estudo para corredores ecológicos no setor Oeste da RBCV, foi possível delimitar as áreas com usos compatíveis que comporiam sua estrutura ecológica básica. Posteriormente, com uma mudança da escala de abordagem, apontamos a viabilidade estrutural da configuração de corredores ecológicos por meio da definição do traçado de eixos principal e secundários dentro das faixas indicativas. Ou seja, desenvolvemos um método que se apropriou dos elementos naturais existentes para a indicação de um traçado possível e mais qualificado, do ponto de vista ecológico, para a implementação de elos de conexão entre a as áreas de conservação apresentadas. Com este resultado, corroboramos a hipótese inicial, demonstrando o potencial da área estudada e de adaptação e aplicação de uma metodologia de planejamento ecológico da paisagem capaz de constituir um sistema de corredores a partir dos elementos existentes no mosaico das paisagens locais.

Merece ser destacada a abordagem multiescalar aqui empregada, fundamental na metodologia utilizada, como uma importante ferramenta para lidar com as questões relacionadas ao desenho de um sistema de corredores, em uma situação de grande complexidade do mosaico da paisagem, como a estudada. Foi fundamental partirmos da abordagem regional para então definir, por meio dos critérios apresentados, a área de abrangência onde o macro corredor ecológico encontrou possibilidades de ser delineado; em seguida, propomos as marcações das faixas indicativas de corredores, a partir das quais pudemos delimitar detalhadamente sete alternativas, demonstrando a viabilidade de suas implantações nos setores selecionados, mesmo que tenhamos assumido compromissos variados de integridade física e biológica.

Por meio da metodologia proposta, pudemos avaliar que este macro corredor ecológico regional também garante uma mínima integridade da estrutura ecológica fundamental que ainda não foi ocupada por usos urbanos intensivos. Além de apontar em que trechos devem ser promovidas as conexões entre os fragmentos, o desenho obtido capacita o mosaico da paisagem existente para manter as funções ecológicas (vegetação, rede hídrica, áreas inundáveis, áreas com riscos de deslizamentos e as áreas permeáveis), dentro do trecho estudado. E também para além dele, sendo possível visualizar uma conexão mais abrangente e estratégica, entre as grandes reservas de Mata Atlântica do sudoeste do estado, com as localizadas nas serras ao norte e nordeste da RMSP. 
O zoneamento incidente da RBCV foi elaborado para uma área extensa, abrangendo 73 municípios. Possui 1.611.710 ha, em uma escala de avaliação regional que não leva em consideração os fragmentos menores, nem os elementos naturais mais pontuais. A premissa inicial adotada para o estabelecimento do zoneamento regional foi a de apropriação das áreas de conservação já regulamentadas pela legislação ambiental estadual e municipal, definindo, por meio delas, áreas Núcleo, Amortecimento e Transição e Cooperação. Já as possibilidades de implementação dos corredores desenvolvidas neste trabalho foram oriundas da própria estrutura ecológica da paisagem, trazendo consigo mais serviços e benefícios ecológicos para o local onde foi testada a metodologia. Isso garantiu um avanço ao zoneamento prévio, pois mais áreas com potencial para conservação e conexões foram resgatadas e tiveram sua importância valorizada, demonstrando que devem ser destacadas, mesmo no contexto regional.

Ou seja, para o zoneamento da RBCV, a área estudada corresponde a uma Área de Transição e Cooperação, com alguns elementos de áreas de Amortecimento; entretanto, tendo sido realizado este estudo, constatamos que se tratam também de áreas com valor ecológico. Se o valor ecológico não é suficiente para espécies de exigências especialistas, ou se essas áreas não possuem espaço suficiente para abrigar grandes mamíferos ou a enorme riqueza de espécies vegetais, tem ainda importância como abrigo de fauna. De fato, esse aspecto pôde ser constatado por meio da lista de espécies da região, mostrando que um grande número de animais se beneficiaria bastante com a manutenção de seu abrigo e fonte de alimento, além dos benefícios estendidos também para o ambiente urbano, sistema hídrico e população.

A área estudada se caracteriza como Reserva da Biosfera Urbana. Sendo assim, os dados da pesquisa e seus produtos podem ser utilizados como subsídios ao planejamento, à gestão e implementação de projetos para tais áreas periurbanas, onde os ambientes natural, socioeconômico e cultural são moldados por fortes influências e pressões urbanas. O objetivo é mitigar essas pressões, levando à melhoria da sustentabilidade urbana e regional, sendo necessário, portanto, incluir as áreas urbanas como locais que precisam de medidas dessa natureza para se tornarem menos hostis aos fluxos ecológicos. Também são fundamentais propostas e ações que regulem adequadamente a expansão urbana dentro da RBCV, de modo que não haja perda de recursos naturais, de conexões e até mesmo que algumas de suas áreas possam ser restabelecidas, visando aumentar o contínuo de vegetação e habitats dentro da reserva.

Os resultados obtidos nesta pesquisa podem se somar às discussões dos gestores da RBCV, como mais um elemento para ser organizado junto aos demais, de maneira a conciliar a conservação de recursos naturais e desenvolvimento humano, e agregar ao conceito de RB mais elementos para as avaliações. 
De modo geral, a partir dos resultados obtidos na avaliação do crescimento urbano e supressão de vegetação em 35 anos, pudemos identificar um processo de fragmentação e supressão de vegetação de porte arbóreo, inicialmente identificado nas imagens de 1975, e depois em 1986 e 1995. De modo geral, o desmatamento nesse período foi difuso; os fragmentos foram sendo suprimidos pelas suas bordas, tornando suas áreas cada vez menores ao longo dos anos avaliados. Houve pontos em que observamos maior supressão da vegetação, e em alguns trechos essa concentração foi mais intensa, dando lugar, em geral, a áreas urbanizadas.

Os dois maiores focos de supressão de vegetação estão localizados na parte norte do trecho estudado e indicam que o corte de árvores e aumento da fragmentação são processos mais antigos do que na parte sul, tendo maior repercussão e diminuição da vegetação. Já nas partes central e sul, identificamos visualmente outros pontos de supressão mais concentrada, mas que se confundem muito com o processo de supressão difusa claramente identificado na primeira observação.

As informações a respeito da dinâmica temporal da paisagem estudada nos permitiram direcionar as investigações de planejamento ecológico da paisagem regional para os pontos em que os vetores de crescimento vêm causando transformações e impactos mais significativos em seus elementos naturais. Ou seja, serviram como uma base para a estratégia de desenhar um contínuo de elementos naturais, o qual deve, portanto, lidar com situações de barreiras aos fluxos ecológicos, que são resultantes dos processos de crescimento urbano, da presença de rodovias e estradas e da supressão da vegetação.

Houve um crescimento das áreas urbanizadas de 54\% durante 24 anos, de caráter concentrado em alguns trechos. Isso ocorreu em função das facilidades e infraestruturas criadas pelas rodovias, pela linha de trem metropolitano da CPTM, por empreendimentos imobiliários, como condomínios e loteamentos de alto e médio padrão, e também de alguns locais para habitações populares. O polo mais significativo de crescimento urbano nesse período aconteceu entre os municípios de Barueri, Itapevi, Jandira e Santana do Parnaíba. Em Cotia e Carapicuíba, o crescimento urbano também se apresentou intensivo. Em todas as situações de adensamento, percebemos claramente uma ligação com as rodovias, que funcionam como vetor de indução ao desenvolvimento dessas áreas.

Os princípios empregados de Ecologia da Paisagem, Estrutura Ecológica da Paisagem e Unidades da Paisagem se mostraram eficazes para ser incorporados no processo de delineamento do sistema de corredores. Com relação à conectividade e fragmentação, estes foram conceitos essenciais que justificam a implementação de um contínuo de áreas abertas. Não avaliamos a conectividade funcional do sistema proposto, pois, para esta discussão, seriam necessários estudos de ecologia da 
paisagem específicos, de modo a testarmos, por meio de modelos ecológicos, a funcionalidade dos corredores para diferentes grupos de espécies. Pudemos apresentar apenas uma avaliação do potencial estrutural que a paisagem oferece para a criação dos corredores, o que já representa um grande passo, pois poderá ser complementada com estudos mais específicos relacionados aos grupos de animais. As múltiplas funções do sistema estrutural de corredores podem ser exploradas também para atividades humanas, como sua eficiência como condutor de faixas cicláveis, para o transporte alternativo de pessoas, recreação e práticas esportivas.

Assim, pudemos empregar a conectividade estrutural como um objetivo a ser atingido para direcionar a proposta de avaliação da paisagem. Nessa perspectiva, os corredores definidos foram suficientes para promover essa conectividade, mesmo não sendo inteiramente contínuos, e sim com interrupções causadas por rodovias, ruas, avenidas, núcleos urbanos e pela proximidade com estes elementos. Aqui, a conectividade não pôde ser medida para um grupo específico da fauna ou de vegetação, e sim tratada de uma maneira geral.

A distribuição geral dos fragmentos com maior importância para condução de fluxos ocorre da seguinte forma: no Eixo Principal, encontramos as áreas com mais potencial para condução de fluxos ecológicos (Classes de Importância 9 e 8) e que possuem área superior a $3 \mathrm{~km}^{2}$, a maior parte delas concentrada na parte sul do eixo, exatamente no limite da reserva do Morro Grande. Também estão concentradas na parte norte e correspondem à vegetação do Parque Estadual da Cantareira, bem como às áreas incluídas na Zona Especial de Preservação Ambiental e Recursos Hídricos (ZEPARRH) do município de Caieiras e na Zona Especial de Proteção Ambiental no município de São Paulo. Os fragmentos médios, com área entre 0,5 e $3 \mathrm{~km}^{2}$, estão localizados próximos às áreas de conservação e aos fragmentos maiores. Os fragmentos menores do que $0,5 \mathrm{~km}^{2}$ estão distribuídos ao longo de todo o eixo.

Na parte central do eixo, há o predomínio de áreas com Classe de Importância 4, com fragmentos médios entre 0,5 e $3 \mathrm{~km}^{2}$, para condução de fluxos e fragmentos menores das diferentes classes de importância.

O grau de ameaça das espécies encontradas nos fragmentos maiores nos indicou a importância de se conservar e manter grandes manchas de vegetação, como habitats para mantêlas. Com relação à eficiência dos sete corredores delimitados para as espécies de animais, como já destacamos, só podemos obter essa correlação por meio de estudos de ecologia da paisagem específicos, que testem as reais necessidades de cada grupo animal com as características de cada corredor. 
Em relação às espécies de aves de possível ocorrência nas unidades de conservação da região estudada, $50(12,6 \%)$ se encontram sob alguma ameaça de extinção. Destas, seis espécies estão presentes na lista da fauna brasileira ameaçada de extinção, sendo que apenas a pararu-espelho (Claravis geoffroyi) possui status de criticamente ameaçada e está intimamente ligada a florestas com alto grau de preservação - na presente compilação, essa espécie esteve presente apenas no Parque da Cantareira. Uma espécie está classificada como "em perigo" em nível estadual, o caboclinhode-papo-branco (Sporophila palustris), que habita paisagens abertas, como capinzais altos, banhados e capinzais úmidos. Aqui, ele foi registrado na única área de estudo com fisionomia de Cerrado, o P. E. Juquery. Ou seja, são espécies que, para sobreviverem, necessitam de um ambiente com habitats específicos e com baixo índice de perturbações antrópicas.

As outras quatro espécies de aves estão classificas como "vulneráveis" à extinção, sendo raras ou pontuais. Foi por meio da sensibilidade delas às perturbações ambientais que pudemos fazer algumas inferências gerais a respeito da eficiência dos corredores para servirem de abrigo e condução das aves. Constatamos que 178 (46,1\%) delas possuem média sensibilidade e 35 (9,1\%), alta sensibilidade. Já as de baixa sensibilidade totalizam 173 (44,8\%) espécies. Essas características, juntamente com a proporção de espécies endêmicas e/ou ameaçadas, demonstram que as comunidades de aves nas áreas amostradas (fragmentos maiores), assim como o próprio ambiente em que se encontram, estão em um bom grau de preservação.

E ainda, apesar da grande proporção de espécies com baixas exigências ecológicas, as áreas estudadas possuem um grande número delas com dificuldade e/ou incapazes de permanecer em ambientes antropicamente perturbados. Ou seja, a maior parte das espécies encontradas necessita de um habitat com características semelhantes aos preservados nas unidades de conservação para sua sobrevivência. Precisam, portanto, de corredores bem vegetados, com um habitat que lhes possibilite usufruir dos benefícios da mobilidade.

Provavelmente, as espécies de aves com baixa sensibilidade, por serem mais generalistas em suas exigências e mais tolerantes a algumas perturbações, serão as mais beneficiadas com todos os corredores, inclusive os localizados nas faixas indicativas secundárias e nas áreas de amortecimento, transição e até mesmo em alguns núcleos urbanos menos hostis a sua sobrevivência.

Com relação aos mamíferos, das 38 espécies de possível ocorrência para a região, 15 (39,5\%) encontram-se sob algum grau de ameaça ou deficiente em dados. Destas, cinco são citadas na lista de espécies ameaçadas de extinção em nível federal (MMA, 2008), todas consideradas vulneráveis à extinção. Outras três estão presentes na lista de espécies mundialmente ameaçadas (IUCN, 2008). 
Já em nível estadual, 14 estão presentes na lista das espécies da fauna ameaçada de extinção (SMA, 2010), sendo seis consideradas vulneráveis.

Constatamos que uma parcela significativa da comunidade de mamíferos de maior porte depende de habitats florestais, mostrando-se extremamente susceptível à perda e fragmentação. De forma geral, os grandes e médios mamíferos, como os felinos, os canídeos e os porcos, possuem grande capacidade de deslocamento e alta tolerância a diferentes tipos de habitats naturais. São espécies que podem facilmente colonizar paisagens compostas de mosaicos florestais e matrizes permeáveis, desde que a porcentagem de cobertura florestal seja representativa, pois procuram esta fitofisionomia em busca de abrigo e de recursos alimentares. A manutenção de populações viáveis requer que as áreas sejam conservadas e mantidas protegidas contra a caça. Os primatas, a paca $(C$ paca), a anta (T. terrestris) e a lontra (L. longicaudis) são também exemplos de espécies que dependem da manutenção de grandes áreas florestais para sua permanência na região. Mamíferos arborícolas, como os primatas e as preguiças, são mais exigentes quanto ao habitat e à distribuição, apresentando capacidade de deslocamento mais limitada, restringindo-se somente a ambientes florestais.

Com relação aos corredores, a maior parte das espécies de mamíferos, as que possuem maior capacidade de deslocamentos, poderão obter os maiores benefícios, por meio de maior oferta de habitat, estímulo ao deslocamento e maior segurança, devido às pontes de travessias de animais e controle das margens das estradas. Para evitar acidentes, estas margens poderão ter cercas de proteção e outras medidas, como sinalização e limite de velocidade.

Podemos inferir, então, que o aumento da conectividade (construção de corredores) poderá aumentar o número de espécies nas áreas menos conectadas, além de levar um maior número delas, mesmo as menos exigentes, para as áreas mais urbanas através dos corredores secundários.

Verificamos que as rodovias se configuram como barreiras que mais dificuldades causam, impossibilitando a passagem de muitos grupos de animais. Sendo assim, apontamos a necessidade de planos de gestão das rodovias para mitigação de atropelamentos e afugentamento de animais, com a implantação de pontes para travessias e instalação de cercas de proteção em áreas com mais índice de acidentes. Os núcleos urbanos causam também a alteração e diminuição de fluxos e processos ecológicos; recomendamos então medidas de controle da expansão urbana sobre as áreas com maior importância ecológica e que formam áreas núcleo do sistema de corredores.

Sobre as possibilidades de implementação dos corredores, como já dissemos, conseguimos traçar sete. 
No Setor 1 do Eixo Principal, definimos dois, o primeiro deles o Corredor CantareiraJuqueri, com a função de conectar os dois parques, não só estruturalmente, pois podemos inferir, pela integridade de seus fragmentos e dos parques do entorno, que terá condições de promover deslocamento dos animais identificados na região. O segundo corredor ecológico demarcado nesse setor, o Corredor Caieiras, só pode ser assim considerado se as diretrizes de criação de áreas de amortecimento e de transição forem seguidas, bem como as de implementação de áreas núcleo adicionais.

No Setor 2 do Eixo Principal, identificamos duas possibilidades de corredores ecológicos, Corredor Aldeia e o Corredor Tietê. Assim como em Caieiras, a viabilidade e manutenção deles estão condicionadas a medidas de controle e regulamentação da ocupação nas áreas marcadas como amortecimento e transição.

No Setor 3, foi possível estabelecer um corredor denominado Corredor Morro GrandeItapevi, integrado a áreas do sistema úmido do Rio Itapevi. Na Faixa Secundária Indicativa 1, verificamos a possibilidade de conexões entre os fragmentos por quase todo o trecho, marcamos o corredor Cotia-Taboão ao norte da faixa por concentrar fragmentos de maiores valores ecológicos e estar mais distante dos loteamentos do interior da APA EMBU. A Faixa Secundária Indicativa 3 é entremeada por uma matriz urbana muito densa, e mesmo com as diretrizes propostas para a possibilidade de configurar um corredor ecológico, o mesmo não poderá ser contínuo, e sim seguir o modelo de Trampolins Ecológicos. Isso porque existem descontinuidades devidas a núcleos urbanos consolidados e muitas rodovias, mas que podem promover beneficios e serviços ambientais, além de permitir abrigo e deslocamento para a avifauna urbana, de características e necessidades mais generalistas.

Com as avaliações realizadas, constatamos o potencial estrutural dos corredores de um contínuo de espaços abertos, com vegetação de diferente composição. Desta forma, o incremento de corredores será mais importante nas áreas com menor proporção de vegetação arbórea e mais fragmentada, como na central do corredor principal.

Marcamos ainda treze conflitos, que não são obviamente os únicos. Sabemos que, quanto mais nos aproximarmos do setor e dos corredores, outros ficarão em evidência. Com as marcações, verificamos que são conflitos relacionados à presença de rodovias, que podem ser estendidos para estradas, avenidas e ruas, e que, na verdade, têm a mesma característica de segregar fragmentos, trazendo o risco de atropelamento para animais e afugentando muitos deles, de modo que não consigam se deslocar. O outro conflito frequente se relaciona aos núcleos urbanos, que acabam por afugentar muitas espécies mais sensíveis, alterando e removendo habitats. 
A marcação realizada serviu para apresentarmos e discutirmos alguns exemplos dos conflitos existentes, sendo que alguns representam impedimentos e dificuldades para fluxos ecológicos. Com esta discussão apontamos algumas possibilidades de mitigação por meio das propostas dos corredores (Mapa 27 a 31) e das passagens e travessias de animais para o conflito das rodovias e estradas.

Os planos diretores municipais incidentes sobre a área pesquisada tiveram suas regulamentações ambientais estudadas sucintamente, de modo que pudemos observar aquelas com valor ecológico protegidas e as que não estão protegidas por legislação municipais. Entretanto, cada município utiliza uma terminologia para suas áreas protegidas, de maneira que não pudemos verificar as reais implicações jurídicas de cada uma delas, apenas identificar e citar algumas das áreas de proteção e parques propostos, áreas de interesse, macrozonas e zonas, contidas nos planos diretores.

Em todos os municípios existem regulamentações mínimas relacionadas à sua importância ecológica, e em muitos deles existem zonas e macrozonas muito gerais. As informações que obtivemos não abordam as implicações, restrições e propostas relacionadas a essas áreas, de maneira que não sabemos a que ponto, de fato, estão isentas de usos e de quais medidas estão de fato protegidas. Recomendamos que seja realizado um estudo mais detalhado a respeito dessas áreas de proteção contidas nos municípios, esclarecendo o que significa serem protegidas e quais as propostas que já existem nesse sentido. Com essas informações seria possível identificar as áreas que hoje estariam de fato carentes de regulamentação e expostas a usos inadequados que coloquem em risco seu patrimônio ecológico.

As possibilidades de implementação dos corredores estão claramente condicionadas à regulamentação e ao direcionamento da expansão urbana, de maneira a se compatibilizar os interesses de crescimento das cidades e manutenção de áreas com valor ecológico. Sugerimos a inclusão da terminologia do zoneamento da RBCV para a escala que foi avaliada, sendo que as áreas de transição e cooperação seriam de interesse prioritário para propostas de novas estratégias de urbanização e requalificação urbana que levem em consideração os elementos naturais e as áreas prioritárias a serem conservadas (áreas núcleo propostas).

Exemplificamos a proposta de maneira geral, trazendo alguns projetos com situações culturais, ambientais e econômicas distintas das que existem na RMSP. Os elementos da infraestrutura verde puderam ser ilustrados com maior propriedade e detalhes, inclusive por um estudo desenvolvido simultaneamente por nós, agora sim numa situação brasileira típica da RMSP, como o Município de Taboão da Serra. 
Com isso, pudemos mostrar a viabilidade técnica de projetos de paisagem urbana com o redesenho de ruas e calçadas, tendo como enfoque atender aos múltiplos usos que podem ter, além da circulação de automóveis e pedestres, permitindo a existência de árvores e vegetação de outros portes, que não causem conflitos e transtornos à população, de tipologias de drenagem naturalizada, como biovaletas, pisos permeáveis, jardins de chuva. Ou seja: soluções técnicas que garantam benefícios ecológicos para a cidade: recarga de aquíferos, minimização de enchentes, filtragem de poluentes, equilíbrio térmico, sombreamento, habitat para aves e outros animais adaptados às condições urbanas, sem contar a valorização da paisagem, dentre outros serviços que podem ser promovidos.

Trata-se de um conjunto de ações integradas na paisagem de setores urbanos que podem ser vistas como ganho significativo para a diminuição do contraste entre a matriz urbana e os corredores que a atravessam, de modo a ampliar seus desempenhos.

Mesmo questionadas, as passagens de fauna apresentam diversos casos de sucesso, os quais procuramos descrever. Atualmente, estas seriam soluções possíveis para mitigar os impactos de rodovias para o deslocamento da fauna, pois diminuem atropelamentos e permitem conexões, configurando-se como benefícios que vêm sendo testados em diversos países. Essas travessias devem continuar a ser estudadas por ecólogos e biólogos e ter seu desenho e abordagens também indicados por arquitetos da paisagem, que podem colaborar com a questão. Desta forma, podem servir como uma medida mitigadora eficiente, colaborando com a viabilidade de elos no sistema de corredores propostos.

Para finalizar, colocamos os fatores culturais, de educação ambiental e lazer da proposta discutida. Acreditamos que a existência de um sistema de parques e corredores integrados deverá facilitar o acesso da população a equipamentos esportivos e recreativos. Diretamente beneficiados pelo sistema, os moradores podem ser incentivados a participar dos trabalhos de manutenção, fortalecendo a relação com os próprios sistemas de suporte da vida urbana e disseminando o conhecimento sobre os parques e as áreas conservadas de vegetação da Mata Atlântica, fauna regional, conectividade e valor das áreas naturais protegidas, como parte de sua infraestrutura verde. 
REFERÊNCIAS BIBLIOGRÁFICAS 


\section{REFERÊNCIAS BIBLIOGRAFICAS}

AHERN, J. From landscape research to landscape planning - Aspects of Education, Integration and Application. Gunther Tress and Barbel Tress, 2005. Editors. Wageningen University, Alterra, Netherlands.

AHERN, J. Planning for an extensive open space system: linking landscape structure an function in Landscape and Urban Planning, 1991.vol.21, p. 131-145. Elsevier Science Publishers B.V. , Amsterdan.

ALCAMO,J. et al. Ecosystems and human well-being: a framework for assessment: Millennium Ecosystem Assessment. EUA: Word Resources Institute, 2003.

ALMEIDA, A.F.;VASCONCELLOS, M.K. Fauna silvestre: quem são e onde vivem os animais na metrópole paulistana. São Paulo: Secretaria Municipal do Verde e do Meio Ambiente, 2007. 350 p.

AMBIENTAL CONSULTING. 2008. Plano de Manejo da Reserva Biológica Municipal da Serra do Japi - Jundiaí - SP. 481 p. Disponível em <http://www.jundiai.sp.gov.br/ pmjsite/biblio.nsf/V03.01/smpm_serra/\$file/ManejoRebio.pdf

ANTUNES, A.Z.; SANTOS, A.M.R.; ESTON, M.R. 2008. Registros relevantes de aves 
para a grande São Paulo obtidos no Parque Estadual da Cantareira (Nota Científica). Reista do Insituto. Florestal 20(2):221-224.

BAGER, A; FONTOURA,V. Ecologia de Estradas no Brasil - Contexto histórico e perspectivas futuras. Em: Bager, A. (editor). Ecologia de estradas: tendências e pesquisas. Lavras : Ed.

UFLA, 2012. pp13 - 33.

BARRACÓ, H. i N. , PARES, M. i. R., PRAT, A. i N. TERRADAS, J. i S. Barcelona: 1985 - 1999 Ecologia d' una ciutat. Barcelona: Comisssióde Medi Ambient i Serveis Urbans. Ajuntament de Barcelona , 1999 .

BARTALINI,V.; LIMA, C. P. C. S; PALLAMIN,V. Abrindo Espaço na Metrópole. Projetos para espaços Públicos no Centro de São Paulo. In Revista Perspectivas Urbanas/Urban Perspectives, 2005. vol 6. Acessado: http://www.etsav.upc.edu/urbpersp/num06/art06-3.htm acessado em $03 / 12 / 2011$.

BEGON, M.; TOWNSEND, C. R. ; HARPER, J. L. Ecology From Individuals to Ecosystems. Oxford:Editora Blackwell, $4^{a}$. Edição, 2006.

BENEDICT, M. Green infraestructure: linking landscapes and communities. Washington D.C.: Island Press, 2006.

BENNET,A. F. Linkages in then Landscape:The role of Corridors and Conectivity in Wildlife Conservation. Gland, Switzerland and Cambridge, UK: IUCN, 2003.

BEUNEN, R. \& HAGENS, J. E. The Use of the Concept of Ecological Networks in Nature Conservation Policies and Planning Practices. Landscape Research, 2009.Vol. 34(5),p. 563 - 580.

BLACK, W.R.; DUI, P.; TOBAR, D.I. Piano per la valorizzazione delle risorce territoriali della zona nord occidentale della provincia di Sassari. California State Pomona: Polytechnic University, 1991. 
BORGUI, C.E; CAMPOS, C.M., OMTUNO, N. BENINATO,V.ANDINO, CAMPOS, V.DE LOS RIOS, C. CAPPA, F. GIANNONI, S.M. Efeitos indiretos sobre a fauna do corredor bioceânico central em uma área protegida do deserto do monte: Parque provincial Ischgualasto. Em: Bager, A. (editor). Ecologia de estradas: tendências e pesquisas. Lavras : Ed. UFLA, 2011. p. $237-252$.

BRESSAN, P.M.; KIERULFF, M.C.M; MIDORI, A. Fauna Ameaçada de Extinçao no Estado de São Paulo: Vertebrados. São Paulo: Fundação Parque Zoológico de São Paulo: Secretaria de Meio Ambiente, 2009. 645 p.

BROOKS, T.; TOBIAS, J. \& BALMFORD, D. A. Deforestation and bird extinction in the Atlantic forest. Animal Conservation, 1999. vol 2, p. 211-222.

BRUSSARD,P.F.; REED, M.R.;TRACY, C.R.." Ecosystem Management - what is it really?” In Landscape and Urban Planning, 1998. vol. 40, p. 9 - 20.

CENTRO DE ESTUDOS ORNITOLÓGICOS. 2008. Lista das aves do Parque Ecológico do Tietê, SP. Disponível em <http://www.ceo.org.br/parqu/listas/Tiete-PE.xls>.

CITY OF ZURIQUE. Streams. 2007.

COMITÊ BRASILEIRO DE REGISTROS ORNITOLÓGICOS (CBRO). 2011 Lista das aves do Brasil.Versão 27/1/2011. Disponível em <http://www.cbro.org.br>. Acesso em: 20 de dezembro de 2011.

CONSÓRCIO JGP/PRIME. 2010. Estudo de Impacto Ambiental - EIA - Programa Rodoanel Mário Covas:Trecho Norte.Volume IV: Meio Biótico. 451 p. Disponível em <http:// www.dersa.sp.gov.br/rodoanel/trechonorte/eia_trecho_norte.asp

CORMIER, N. S. PELLEGRINO, P. R. M.. Infra-estrutura Verde: Uma estratégia paisagística para a água urbana In Paisagem e Ambiente: ensaios. Universidade de São Paulo, Faculdade de Arquitetura e Urbanismo, 2008. vol. 25. São Paulo: FAU.

COSTA, R. 2006. Impactos sobre remanescentes florestais de Mata Atlântica na Zona Oeste da Grande São Paulo: Um estudo de caso da mata da Fazenda Tizo. Dissertação Mestrado. Depto. de Geografia, Faculdade de Filosofia Letras e Ciências Humanas, São Paulo. 
CPRM/SGB , Companhia de Pesquisas e Recursos Minerais, do Ministério de Minas e Energia, e Serviço Geológico do Brasil . Carta Geológica do Estado de São Paulo . São Paulo, 2010. Disponibilizado pelo site http://www.cprm.gov.br/ Acessado em 21/01/2010.

CULLEN JR., L.; BODMER, E.R.;VALLADARES-PADUA, C. 2000. Effects of hunting in habitat fragments of the Atlantic forests, Brazil. In Biological Conservation, 2000. vol. 95, p. 49-56.

CUNHA, N.S.C. 2007. Do Sistema- Paisagem a Morfologia do Terreno. Dissertação Mestrado. Instituto Superior de Agronomia/Universidade Técnica de Lisboa, Lisboa, Portugal.

D’ÁLGE, J.C.L. Cartografia para Geoprocessamento. In: Câmara, G.; Davis, C.; Monteira, A.M.V. Em Introdução a Ciência da Geoinformação. São José dos Campos: INPE. Livro Disponível on line (www.dpi.inpe.br)., 2001.

DAllmAN, S. \& PIECHOTA,T.. Storm Water: Asset not Liability. The Los Angeles \& San Gabriel Rivers Watershed Council: Los Angeles, 1999. Disponivel em www. LACGRiversWatershed.org. Acessado em 20/08/2006.

DAVIS, A. P. \& McCUEN, R. H. 2005. Stormwater Management for Smart Growth Springer, New York, 2003.

DE VIVO, M.; CARMignOtTO, A.P.; GREGORIN, R.; HINGST-ZAHER, E.; IACK-XIMENES, G.E.; MIRETZKI, M.; PERCEQUILLO, A.R.; ROLLO, M.M.; ROSSI, R.V.; TADDEI,V.A. Checklist dos mamíferos do Estado de São Paulo, Brasil. Biota Neotropica, 2011. vol 11 (1). Disponível em: http://www.biotaneotropica.org.br/v11n1a/pt/abstract?inventory+bn007 1101a2011>. Acesso em fevereiro de 2012.

DEPAVE, Departamento de Áreas Verdes da Cidade de São Paulo. Manual técnico de Arborização Urbana, 2005

DERSA, Departamento de Estradas e Rodagens de São Paulo. Relatório de Impactos Ambientais - RIMA do Rodoanel Mario Covas - Trecho Norte. Consórcio JGP / Prime, 2010.

DEVEley, P.; MARTENSEN, A.C. Aves da Reserva Florestal do Morro Grande (Cotia, SP). In Biota Neotropica, 2006. vol. 6(2), p. 1-16. 
DEVELEY, P.F; BENCKE, G.A., MAURÍCIO, G.N.,. AND GOERCK, J.M. Áreas Importantes para a Conservação das Aves no Brasil. Parte I - Estados do Domínio da Mata Atlântica. São Paulo: SAVE Brasil, 2006.

DORNAS, R. A.P, KINDEL, A.. BAGER, A., FREITAS, S.R. Avaliação da mortalidade de vertebrados em rodovias no Brasil. Em: Bager, A. (editor). Ecologia de estradas: tendências e pesquisas. Lavras : Ed. UFLA, 2011. p. 139- 152.

DUnNetT, N; HitChMOUGH,J. The Dynamic Landscape. Abingdon, 2008.

EISENBERG, J.F; REDFORD, K.H. Mammals of the Neotropics, the Central Neotropics - Ecuador, Peru, Bolivia, Brazil. Chicago and London: The University of Chicago Press, Volume 3, 1999.

EMPLASA, Empresa Paulista de Planejamento Metropolitano. Fotografias Ortorretificadas da Regiao Metropolitana de São Paulo, São Paulo, 2007.

EMPLASA, Empresa Paulista de Planejamento Metropolitano. Base Cartográfica do Uso do Solo e Temática da Região Metropolitana de São Paulo, São Paulo: 2006.

ENCIBRA ESTUDOS E PROJETOS DE ENGENHARIA. 2010. Estudo de impacto ambiental - EIA - Sistema Produtor São Lourenço. Diagnóstico da fauna terrestre 112 p.

FAHRIG, L., Effects of habitat fragmentation on biodiversity. In Annual Review of Ecology, Evolution and Systematic, 2003. vol. 34, 487-515.

FAHRIG, L., How much habitat is enough? In Biological Conservation, 2001. vol. 100, 65-74.

FAHRIG, L.,. Relative effects of habitat loss and fragmentation on population extinction. Journal of Wildlife Management, 1997. vol 61, 603-610.

FARINA A. Human Stewardship in Ecological Mosaics: Linking People to Landscape Dynamics Cap 08 In "Landscape ecology and resource management : linking theory with practice / edited by John A. Bissonette and Ilse Storch. Island Press, Washington, 2003. p. 177 - 192. 
FF, Fundação Florestal do Estado de São Paulo. Plano de Manejo do Parque Estadual da Cantareira. São Paulo, 2009. Disponibilizado em http://www.fflorestal.sp.gov.br/ planodemanejoCompletos.php acessado em 18/10/2011.

FIGUEIREDO, L.F. A.; GUSSONI, C.A.O; PACHECO, J.F; SILVEIRA, LF. E GRANTSAU, R. 2009. Lista das aves do estado de São Paulo. Disponível em < http://www.ceo. org.br/> Acesso em 7 de dezembro de 2011.

FIGUEIREDO, L.F.F; GUSSONI,C.O.A.G.; SANTOS,R.P. Levantamento da avifauna do Parque Estadual Juquery, Franco da Rocha, São Paulo: uma avaliação auto-crítica das técnicas de campo para inventários ornitológicos. In Boletim CEO, 2000. vol. 14, p. 36-45.

FLOREZ,A. Adopting a modern ecological view of the metropolian landscape: the case of greenspace system for the New York region. In Landscape and Urban Planning. Amsterdan: Elsevier Science Publishers B., 1997.v., 39 , p. 295-308.

FORMAN, R.T.T., GODRON, M.. Landscape Ecology. New York: John Wiley \& Sons, 1986.

FORMAN, R. T. T.. Land Mosaics: The Ecology of Landscapes and Regions. Cambridge: Cambridge University Press, 1995.

FORMAN, R. T. T.; ZONNEVELD, I. S.. Changing landscapes: An ecological perspective. New York: Springler-Verlag, 1990.

FORMAN, R.T.T Some General Principles of Landscape and Regional Ecology. In Landscape Ecology, 1995. vol. 10 (3), pp $133-142$.

FORMAN, R.T.T. Mosaico territorial para la región metropolitana de Barcelona. Barcelona regional/ Editorial Gustavo Gili SA, Barcelona, 2004, 150 pp.,

FORSYTH, A. Designing small parks; a manual for addressing social and ecological concerns. Hoboken: John Wiley, 2005.

FRISCHENBRUDER, M.T M.; PELLEGRINO, P.R. M. . Using greenways to reclaim nature in Brazilian cities. In Landscape and Urban Planning. Amsterdam: Elsevier Science Publishers B., 2006. vol. 76, (1-4), p. 67-78. 
FUSP - Fundação de Apoio à Pesquisa à Universidade de São Paulo/FAUUSP -

Faculdade de Arquitetura e Urbanismo da Universidade de São Paulo. Relatório Técnico Fase VII

- Vegetação Viária Projeto Natureza de Taboão da Serra, São Paulo: 2009.

FUSP - Fundação de Apoio à Universidade de São Paulo /FAUUSP - Faculdade de Arquitetura e Urbanismo da Universidade de São Paulo. Relatório Técnico Fase IV-Fauna.

Projeto Natureza de Taboão da Serra, São Paulo, 2009.

GARRIDO, H ( fotógrafo); RUIZ, J.M.G. (diretor científico) Exposición temporal: “Armonía fractal de Doñana y las Marismas. Madrid, Espanha , Real Jardim Botanico: Consejo Superior de Investigaciones Científicas, 2010.

GOLDENBERG, R. \& VARASSIN, I. G. Sistemas reprodutivos de espécies deMelastomataceae da Serra do Japi, Jundiaí, São Paulo, Brasil. In Revista Brasileira de Botânica, 2001. vol 24 (3), p.283-288.

GRAHAM, D.J. The Avifauna of the Serra da Cantareira, São Paulo, Brazil: a preliminary survey. In Instituto Florestal Série Registros, 1992. vol. 10, p. 1-56.

GRILO, C. A rede viária e a fauna - Impactos, mitigação e implicações para a conservação das espécies em Portugal. Em: Bager, A. (editor). Ecologia de estradas: tendências e pesquisas. Lavras : Ed. UFLA, 2011. p.35 - 57.

GRONDONA, A. E. B., Avaliação da acurácia dos classificadores de máxima verossimilhança, mínima distância euclidiana e isodata na classificação de imagens da região do Pantanal. In. Anais do $2^{\circ}$ Simpósio de Geotecnologias do Pantanal, Corumbá, 7-11 novembro 2009, Embrapa Informática Agropecuária/INPE, p.433-442.

GRÜN STADT, Grün Stadt Zürich, Office of Parks and Open Spaces Civil Engineering and Waste Management Department of the City of Zurich, Ed. by Cordula Weber et al. The Green Book of Zurich, Integral planning - out come - oriented action. Zurique: $1^{\mathrm{a}}$. Ed, 2006. http://www.ifla2011.com/the-green-book-of-zurich.html, acessado em 15/12/2011.

HELLMUND, P \& SMITH, S. org. Ecology of Greenways: Design and Function of Linear Conservation Areas. Minneapolis: University of Minnesota Press, 1993. 
HELLMUND, P. H, Designing Greenways - Sustainable Landscapes for Nature and People. 1993). Washington D.C: Island Press, 2006.

HICKMAN JR., J.P.; LARSON, A.; ROBERTS, L.S. Princípios Integrados de Biologia/Zoologia. Rio de Janeiro: Guanabara Koogan, 11'. Ed, 2004. 872 p.

HILTY, J. ; LIDICKER, W.Z. JR., MERENLENDER A.; ANDREW P. DOBSON, A. P. Corridor Ecology: The Science and Practice of Linking Landscapes for Biodiversity Conservation. Washington: Island Press, 2006.

IB; Instituto de Botânica de São Paulo. Diretrizes para Conservação e Restauração da Biodiversidade do Estado de São Paulo. São Paulo: BIOTA/FAPESP Disponível eletronicamente em http://www.ambiente.sp.gov.br/cpla/files/100111_biota_fapesp.pdf., 2008. Acessado em 02/02/2012.

INPE "Introdução ao Processamento de Imagens" in Spring - Manuais. São José dos Campos. s.d. disponível em http://www.dpi.inpe.br/spring/portugues/tutorial/introducao_pro.html

INTERNATIONAL UNION FOR CONSERVATION OF NATURE (IUCN). 2008 Red List of Threatened Species. Disponível em <www.iucnredlist.org>. Acessado em 30 de dezembro de 2011.

JOHNSON, B. R. \& HILL, K. Ecology and Design - Frameworks for learning. , Washington DC: Island Press, 2002.

JONGMAN, R. Book Review: from Boston to Barcelona: A Landscape Ecological Vision In Regional Planning Landscape Ecology, 2006. vol. 21, p. 155-156.

KAGEYAMA, P.Y.; OLIVEIRA, R. E.; MORAES, L.F.D.; MENDES, F.G.; ENGEL, V.L. Restauração Ecológica de Ecossistemas Naturais. Botucatu: FEPAF, 2003. 340 p.

KEMP, T.S. The Origin and Evolution of Mammals. New York: Oxford University Press Inc, 2005. $331 \mathrm{p}$.

KORMAN, V. 2003. Proposta de interligação das glebas do Parque Estadual de Vassununga-Sta Rita do Passa Quatro, SP. Dissertação de Mestrado. ECOAGROEC, Escola Superior de Agronomia Luiz de Queiróz/ ESALQ , Universidade de São Paulo, Piracicaba-SP. 
LAMBECK, R.J. Focal Species: A Multi-Species Umbrella for Nature Conservation. In Conservation Biology, 1997.Vol. 11 (4), p. 849 - 856.

LEITÃO, A. B.; AHERN, J. Measuring Landscapes - A Planner's Handbook. Washington D.C: Island Press, 2006.

LEITE, J.R. 2008. A Ecologia da Paisagem no Planejamento Ecológico de Bacias Hidrográficas Urbanas. Dissertação de Mestrado, Faculdade de Arquitetura e Urbanismo, Área de Concentração: Paisagem e Ambiente, Universidade de São Paulo, São Paulo.

LEITE, R.M.S ; BÓÇON, R.; BELÃO; M.; SILVA,J.C. Atropelamento de mamíferos silvestres de médio e grande porte nas Rodovias PR-407 e PR-508, Planície Costeira de estado do Paraná, Brasil. Em: Bager,A. (editor). Ecologia de estradas: tendências e pesquisas. Lavras : Ed. UFLA, 2012. pp193 - 205.

LINDENMAYER D. B.; MANNING, AD; SMITH ,P.L.; POSSINGHAM, H.P; FISCHER,J.; OLIVER, I.; MCCARTHY ,M.A. The Focal-Species Approach and Landscape Restoration: a Critique. Conservation Biology, 2002. vol. 16 (2) p. 338-345

LINO, C. F., DIAS, H. ALBUQUEQUE, J.L.R (org.). Reserva da Biosfera da Mata Atlântica - Fase VI/2009 - Revisão e Atualização dos Limites e Zoneamento da Reserva da Biosfera da Mata Atlântica em Base Cartografica Digitalizada. São Paulo: Conselho Nacional da Reserva da Biosfera da Mata Atlântica, 2009.

LINO, C. F.; DIAS, H.; ALBUQUERQUE, J. L. R.(org) Reserva da Biosfera da Mata Atlântica - Fase VI /2009 - Revisão e Atualização dos Limites e Zoneamento da Reserva da Biosfera da Mata Atlântica em Base Cartográfica Digitalizada . Série MaB - UNESCO, Caderno no. 38 . São Paulo: Conselho Nacional da Reserva da Biosfera da Mata Atlântica, 2009.

LUCHIARI, A. Identificação da cobertura vegetal em áreas urbanas por meio de produtos de sensoriamento remoto e de um sistema de informação geográfica. Revista do Departamento de Geografia (USP), São Paulo, vol. 14, p. 47-58, 2001.

LUCHIARI,A. Os produtos do sensoriamento remoto nos mapeamentos do uso e cobertura da terra. In: José Borzacchiello da Silva, Denise Elias, Luiz Cruz Lima. (Org.). Panorama da Geografia Brasileira. 12. ed. São Paulo: Annablume, 2006, v. 2, p. 145-167. 
LYLE, J. Design of Human Ecossystems Landscapes, Land Use and Natural Resources. New York:Van Nostrand Reinhold Company, 1985.

MACHADO, J.R.; FERREIRA, J.F. Greenways for Portugal - A Contribution to an European Network. In Revista Fórum Geográfico - Revista Técnica do IGP, 2007. vol. 2 (2) pp 24 - 37,

MAGALHÃES, M. R. (coord. geral). Estrutura Ecológica da Paisagem: Conceitos e Delimitação, Escala Regional e Local. Lisboa: ISAPress, 2007.

MAgalhães, M. R. A Arquitectura Paisagista - Morfologia e Complexidade, Lisboa: Editorial Estampa, 2001.

MARINHO-FILHO, J. S. Os mamíferos da Serra do Japi. In: Morellato, L.P.C. (org.). 1992. Historia natural da Serra do Japi: ecologia e preservação de uma área florestal no sudeste do Brasil. Campinas: Editora da UNICAMP. 1992.

MARRIS, E. Rambunctious Garden: Saving Nature in a Post-Wild World. New York: Bloomsbury, 2010.

MARTINS-HATANO, F. et al. Estudo dos atropelamentos dos animais silvestres na Floresta Nacional de Carajás, Pará, Brasil. Em: Bager, A. (editor). Ecologia de estradas: tendências e pesquisas. Lavras : Editora UFLA, 2012.p.223-236.

McHARG, I. Design with nature. New York: Natural History Press, 1969.

MERTENS, E. Visualizing Landscape Architecture - Functions, Concepts and Strategies. Basel, Switzerland: Birkhäuser Verlag AG, 2010.

METZGER, J. P.W. Estrutura da Paisagem e Fragmentação: Análise Bibliográfica. In An . Acad. Bras. Ci, 1999. vol. 71, p. $441-462$.

METZGER, J. P.. O que é ecologia de paisagens? Biota Neotrópica, 2001.Vol. 01, n. 1/2, ISSN 1676-0611, Campinas-SP.

METZGER, J.P. Como restaurar a conectividade de paisagens fragmentadas? In: Kageyama, P.Y., 
Oliveira, R.E., Moraes, L.F.D., Engel, V.L. \& Gandara, F.B. (eds.). Restauração ecológica de ecossistemas naturais, Fundação de Estudos e Pesquisas Agrícolas e Florestais - FEPAF, Botucatu, SP, p. 49-76. 2003.

METZGER, J.P.; ALVES, L.F; GOULART, W.; TEIXEIRA, A.M.G.; SIMÕES, S.J.C.; CATHARINO, E.L.M. Uma área de relevante interesse biológico, porém pouco conhecida: a Reserva Florestal do Morro Grande. Biota Neotropica, 2006. vol 6(2), p. 1-33.

MEYER, R. M. P; GROINSTEIN, M.D., BIDERMAN, C. São Paulo Metrópole. São Paulo: Editora da Universidade de São Paulo: Imprensa Oficial do Estado de São Paulo, 2004.

MMA - MINISTÉRIO DO MEIO AMBIENTE. Livro vermelho da fauna brasileira ameaçada de extinção, Volume 2. Brasília: MMA, 2008. 1420 p.

MOILANEN, A. \& NIEMINEN, M.. Simple connectivity measures in spatial ecology. In Ecology, 2002. vol. 83 (4), p. 1131-1145.

MONGE, N. Boudarie as a Project. In 48. IFLA -International Federation of Landscape Architecture-Congress (Anais), 2011.

NAGENDRA, H.;UTKARSH, G. Landscape Ecological Planning Through a Multi-Scale Characterization of Pattern: Studies in the Western Ghats, South India. In Environmental Monitoring and Assessment, 2003. vol. 87, p. 215-233.

NASSAUER J. I. Placing Nature: Culture and Landscape Ecology. Washington, D.C.: Island Press, 1997.

NEGRÃO, M.F.F; VALLADARES-PÁDUA, C. Registros de mamiferos de maior porte na Reserva Florestal do Morro Grande, São Paulo. Biota Neotropica, 2006.Vol. 6(2), p. 1-13.

NOSS, R.F.; QUIGLEY, H.B.; HORNOCKER, M.G.; MERRIL, T.; PAQUET, P.C. Conservation biology and carnivore conservation in the Rocky Mountains. Conservation Biology, 1996. vol. 10 (4), p. 949-963. 
NOVACK T. ; KARAM, H.A. ; LUCHIARI, A. ; CLARO, M. S. ; PEREIRA FILHO, A. J. Mapeamento automático de padrões de urbanização e cobertura da terra na Região metropolitana de São Paulo utilizando imagens CCD-CBERS-2. In: XIII Simpósio Brasileiro de Sensoriamento Remoto. Florianópolis. XIII Simpósio Brasileiro de Sensoriamento Remoto. São José dos Campos: Instituto Nacional de Pesquisas Espaciais - INPE, 2007.v. 1. p. 1001-1008.

NUDBISI, F. Ecological Planning: A Historical and Comparative Synthesis. Baltimore: Johns Hopkins University Press, 2002.

NUDBISI, F. Environmentally sensitive areas: a template for developing greenway corridors In Landscape and Urban Planning, 1995. vol 33, p. 159-177.

OPDAN, P.; FOPPEN R.,VOSS, C. Bridging the gap between ecology and spatial planning in landscape ecology in Landscape Ecology, 2002. vol. 16: p. 767-779.

PAULA, G.C.R; ANTUNES,A.Z;VILELA, F.E.S.P. e ESTON, M.R. Ocorrência e conservação da Anta (Linnaeus, 1758) na Reserva Florestal do Morro Grande, SP, BRASIL. In Revista do Instituto Florestal, 2010.Vol 22(1), p. 51-60.

PELlegrinO, P. R. M. Pode-se planejar a Paisagem? In Revista Paisagem e Ambiente:ensaio vol. 13, São Paulo: FAU, p. 159-179. 2000.

PELLEGRINO, P.R.M. 1995. Paisagem e Ambiente. O processo de aproximação no setor Oeste da Macrometrópole de São Paulo. Dissertação de Doutorado, Faculdade de Arquitetura e Urbanismo ,Universidade de São Paulo, São Paulo.

PELLEGRINO, P.R.M.; GUEDES, P.P.; PIRILLO, F.C. e FERNANDES, S.A.A Paisagem da borda: Uma estratégia para a condução das águas, da biodiversidade e das pessoas. In: Lúcia Maria S. A. Costa (org.), Rios e Paisagens Urbanas em Cidades Brasileiras. Rio de Janeiro:Viana \& Mosley, Editora PROURB, 2006.

PENSE, M.R.; DE CARVALHO, A.P.C. Biodiversidade de aves do Parque Estadual do Jaraguá (SP). Conscientiae Saúde, 2005. Vol. 4, p. 55-62. 
PERES, C.A. Synergistic effects of subsistence hunting and habitat fragmentation on Amazonian Forest vertebrates. Conservation Biology , 2001.Vol. 15 (6), p. 1490-1505.

PINOTTI, B.T. 2010. Pequenos mamíferos terrestres e a regeneração da Mata Atlântica: influência da estrutura do habitat e da disponibilidade de alimento na recuperação da fauna. $124 \mathrm{f}$. Dissertação de Mestrado em Zoologia, Instituto de Biociências, Universidade de São Paulo, São Paulo.

PIVETTA, K. F. L \& SILVA FILHO, D.F. Arborização Urbana - Boletim Acadêmico - Série Arborização Urbana UNESP/FCAV/FUNEP Jaboticabal, SP - 2002.

PMSP - Prefeitura Municipal de São Paulo/ Secretaria do Verde e do Meio Ambiente. Manual Técnico de Arborização Urbana, São Paulo, SP. $2^{a}$ edição, 2005.

PMTS - Prefeitura Municipal de Taboão da Serra. Plano Diretor Municipal Taboão da Serra/SP, 2006

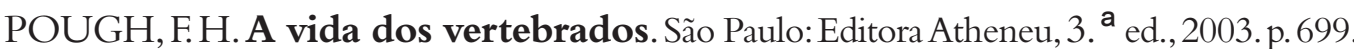

PRINZ, D. Urbanismo I - Projecto Urbano. Lisboa, Editorial Presença, 1980.

RBCV, Reserva da Biosfera do Cinturão Verde de São Paulo. Regimento Interno do Conselho de Gestão da Reserva da Biosfera do Cinturão Verde da Cidade de São Paulo. Deliberação Nº 02/2005 de 23 de Junho de 2005. São Paulo, 2005.

RBCV, Reserva da Biosfera do Cinturão Verde de São Paulo. Sistema de Gestão da Reserva da Biosfera do Cinturão Verde da Cidade de São Paulo. Deliberação No. 01/2007 de 19/06/2007. São Paulo, 2007.

REDFORD, K.H. The Empty Forest. In BioScience: American Institute of Biological Sciences, 1992. vol. 42 (6) (pp. 412-422)

REIS, N.R., PERACCHI, A.L., PEDRO, W.A. \& LIMA, I.P. Mamíferos do Brasil. Universidade Estadual de Londrina, Londrina, 2006.

RODRIGUES, C.R. 1990. Urbanizacão e intervenções no meio físico na borda sedimentar de São Paulo - Uma Abordagem Geomorfológica. Dissertação Mestrado. Depto. de Geografia, Faculdade de Filosofia Letras e Ciências Humanas, São Paulo. 
RODRIGUES, E.A.;VICTOR, R.A.B.M.;PIRES, B.C.C. A Reserva da Biosfera do Cinturão Verde na cidade de São Paulo como marco para a gestão integrada da cidade, seus serviços ambientais e o bem estar humano. In São Paulo em Perspectiva, São Paulo, Fundação Seade, v. 20, n. 2, p. 71-89, abr./ jun. 2006. Disponível em: <http://www.seade.gov.br $>;<$ http://www.scielo.br $>$.

ROSS, J.L.S. Análise empírica de fragilidade dos ambientes naturais e antropizados. In Revista do Departamento de Geografia, São Paulo: Depto. de Geografia/ FFLCH, 1994. vol. 13, p 77 - 106.

SALINAS, E . 1991. Análisis y Evaluación de los Paisajes en la Planificación Regional en Cuba. Tese de Doutorado. Universidad de la Habana, Cuba. 187 pp.

SANTOS, M. A natureza do espaço . São Paulo: Hucitec, $3^{\text {a }}$ Edição, 1999.

SANTOS, R. F. Planejamento Ambiental: Teoria e Prática. São Paulo: Oficina de Textos, 2004

SÃO PAULO. Inventário da fauna do município de São Paulo. Diário Oficial 55(94): 1-114 (suplemento), 2010

SAUNDERS, D. A., HOBBS, R. J.; MAR GULES, C. R. Biological consequences of ecossystems fragmentation: a review. Conservation Biology, 1991. vol 5 (1), pp 18-32.

SECRETARIA DO MEIO AMBIENTE (SMA).21010. Decreto Estadual $\mathbf{n}^{\mathbf{0}} \mathbf{5 6 . 0 3 1}$, de 21 de julho de 2010. Diário Oficial do Estado 120 (136).

SICK, H. Ornitologia brasileira. Rio de Janeiro: Nova Fronteira, 1997. 912 p

SILVA, J. de P. 2005. Expansão Urbana e Evolução Geomorfológica em Remansos de Reservatórios. Dissertação de Mestrado. Depto. de Geografia, Faculdade de Filosofia Letras e Ciências Humanas, Universidade de São Paulo, São Paulo.

SILVA, J.M.C. Endemic bird species and conservation in the Cerrado Region, South America. Biodiversity and Conservation, 1997. vol. 6, p. 435-450. 
SILVA, L. S. 2004. Proteção Ambiental e Expansão Urbana: A Ocupação ao sul do parque estadual da Cantareira. Dissertação Mestrado. Faculdade de Arquitetura e Urbanismo, Universidade de São Paulo, São Paulo.

SILVA,W.R. As aves da Serra do Japi. In: Morellato, L.P.C. (org.) Historia natural da Serra do Japi: ecologia e preservação de uma área florestal no sudeste do Brasil. Campinas: Editora da UNICAMP, 1992.

SOARES et al. Avaliação da viabilidade de classificação de imagens fusionadas pelo uso de método de análise estatística. In Anais XV Simpósio Brasileiro de Sensoriamento Remoto, Curitiba, PR: INPE, 2011, p.2636-2643

SOUZA, J.L.; ANACLETO, T.C.S. Levantamento de mamiferos atropelados na rodovia BR 158, estado de Mato Grosso, Brasil. Em: Bager, A. (editor). Ecologia de estradas: tendências e pesquisas. Lavras : Ed. UFLA, 2012. pp208 - 221.

SOUZA, R.C.;SOUZA, F.M.;ESTEVES, R.;IVANAUSKAS, N.M.; FRANCO, G.A.D.C. 2008. Flora Arbustivo-Arbórea do Parque Estadual do Jaraguá, São Paulo - SP. II Seminário de Iniciação Científica do Instituto Florestal: 1-5.

SPIRN, Anne W. O jardim de granito: a natureza no desenho da cidade. São Paulo: Edusp, 2002.

STEINER, F. Resource Suitability : Methods for Analyses. In Environmental, New York: Springer-Verlag, 1983. vol. 07 (05), p. 401-420.

STEINER, F. The living landscape: An ecological approach to landscape planning (Second Edition). McGraw Hill, New York, 2000.

STEINITZ, C.. A framework for Theory Applicable to the Education of Landscape Architects (and Others Designs Professionals). In Landscape Journal, 1990, vol. 09 (02).

STOTZ, D.; FITZPATRICK, J.W.; PARKER III, T.A.; MOSKOVITS, D. Neotropical Birds: Ecology and Conservation. Chicago:The University of Chicago Press, 1996. 481pp. 
STRAUBE, F.C.; URBEN-FILHO,A. Avifauna da reserva natural Salto Morato (Guaraqueçaba, Paraná). Atualidades Ornitológicas, 2005. vol. 124, p. 12-32.

TABARELLI, M., Baider, C., MANTOVANI, W., Efeitos da fragmentação na floresta Atlântica da bacia de São Paulo. In Hoehnea, 1998. vol 25, p. 169-186.

TABARELLI, M., MANTOVANI, W., PERES, C.A., Effects of habitat fragmentation on plant guild structure in the montane forest of southeastern Brazil. In Biological Conservation, 1999. vol.91, p. 119-127.

TAYLOR, J., PAINE, C.; FITZGIBBON, J. From Greenbelt to Greenway: Four Canadian Case Studies. In Landscape and Urban Planning, 1995. vol 33 , p. 47 - 64.

TELLES, G. Plano Verde de Lisboa. Lisboa: Ed. Colibri, 1997.

TUCCI, C. E. M; Porto, R. L.; Barros, M.T. (org.). Drenagem Urbana. Coleção ABRH, vol 5, Editora Universidade, 1995: 428p.

TURNER, M. G.; GARDNER, R. H., O’NELL, R.V. Landscape ecology in theory and practice - Pattern and Process. New York: Springer-Verlag, 2001.

UEZU,A. 2002. Efeito do tamanho de fragmentos e da conectividade na abundância de sete espécies de aves florestais em Caucaia do Alto, SP. Dissertação Mestrado. Instituto de Biociências. Universidade de São Paulo.

UEZU,A.; METZGER, J.P.W. \& VIELLIARD, J.M. The effect of structural and functional connectivity and patch size on the abundance of seven Atlantic Forest bird species. In Biological Conservation, 2005. vol. 123, p. 507-519.

UNESCO, United Nations Educational, Scientific and Cultural Organization. Reservas de La Biosfera. Su contribucion a La provision de serviços de los ecosistemas. Santiago, Chile: Editorial Valente, 2010.

VELOSO, H.P \& LIMA , J.C. A. Classificação da vegetação Brasileira adaptada a um sistema universal. Rio de Janeiro: IBGE, 1997. 
VERNER, J. Measuring responses of avian communities to habitat manipulation. In Studies in Avian Biology, 1981. vol. 81, p. 543-547.

WIENS, J. A. "Riverine landscapes: taking landscape ecology into the water" In Freshwater Biology, 2002. vol 47, p. 501-515.

WILLIS, E.O. \& ONIKI,Y.. Invasion of deforested region of São Paulo state by the Picazuro Pigeon, Columba picazuro Temminck, 1813. In Ciência e Cultura, 1987. vol 39 (11), p. $1064-$ 1065.

WILSON, D. E.; REEDER, D. M. Mammal species of the World: a taxonomic andgeographic reference. 3o. ed. Johns Hopkins University Press, 2005. 2.142. p. 